NOEL TORRES JÚNIOR

OPERAÇÕES EM SERVIÇOS DE RESULTADOS ULTERIORES: DIRETRIZES GERENCIAIS PARA UM MELHOR DESEMPENHO

SÃO PAULO

2007 
NOEL TORRES JÚNIOR

OPERAÇÕES EM SERVIÇOS DE RESULTADOS ULTERIORES:

DIRETRIZES GERENCIAIS PARA UM MELHOR DESEMPENHO

Tese apresentada à Escola Politécnica da Universidade de São Paulo para obtenção do título de Doutor em Engenharia 
NOEL TORRES JÚNIOR

\section{OPERAÇÕES EM SERVIÇOS DE RESULTADOS ULTERIORES: DIRETRIZES GERENCIAIS PARA UM MELHOR DESEMPENHO}

Tese apresentada à Escola Politécnica da Universidade de São Paulo para obtenção do título de Doutor em Engenharia.

Área de Concentração:

Engenharia de Produção

Orientador: Prof. Dr. Dario Ikuo Miyake

SÃO PAULO 
Este exemplar foi revisado e alterado em relação à versão original, sob responsabilidade única do autor e com a anuência de seu orientador.

São Paulo, 10 de maio de 2007.

Assinatura do autor

Assinatura do orientador

\section{FICHA CATALOGRÁFICA}

Torres Júnior, Noel

Operações em serviços de resultados ulteriores: diretrizes gerenciais para um melhor desempenho / N. Torres Júnior. -São Paulo, 2007. 223p.

Tese (Doutorado) - Escola Politécnica da Universidade de São Paulo. Departamento de Engenharia de Produção.

1.Administração de serviços 2.Administração da produção 3.Serviços I.Universidade de São Paulo. Escola Politécnica. Departamento de Engenharia de Produção Il.t. 


\section{DEDICATÓRIA}

Dedico este trabalho ao meu querido avô Antonio Torres (in memoriam) cujo exemplo de dedicação e aplicação de seu conhecimento à construção de uma vida melhor à sua cidade natal foi e é muito inspirador para mim. 


\section{AGRADECIMENTOS}

Após varias idas e vindas de Belo Horizonte a São Paulo, chegou o momento de finalizar uma difícil empreitada pessoal e profissional. Tenho uma grande dívida com várias pessoas que me ajudaram nessa grande e laboriosa tarefa. Por isso, agradeço a todos que de alguma maneira contribuíram, direta ou indiretamente, para a realização deste trabalho. Em especial:

Meu professor e orientador professor Dario Ikuo Miyake, pela confiança depositada, paciência, dedicação e excepcional e imprescindível orientação. Um grande mestre e um exemplo de pesquisador e docente.

Ao professor Lin Chih Cheng pelo grande incentivo dado para que fizesse o doutorado na Poli-USP.

À PUC-MG pelo apoio financeiro dado por meio do Programa Permanente de Capacitação Docente da PUC-Minas (PPCD) e, em especial, aos professores José Luiz Ferreira e Sara Pimenta Resende pelo empenho colocado para que usufruísse desse benefício.

Também aos professores Paulino Graciano Francischini e Marilson Alves Gonçalves, cujas críticas e comentários proferidos durante a fase de qualificação, foram decisivos para o aprimoramento deste trabalho.

Aos meus pais, demais familiares e amigos pelo apoio e compreensão dados.

Finalmente, à minha amada esposa Heloisa e minhas duas queridas filhas Laís e Elisa que vivenciaram toda essa trajetória, e que, de uma maneira carinhosa, souberam doar seu apoio e compreensão. 


\section{RESUMO}

Esta tese aborda serviços cuja "matéria-prima" é o próprio cliente e que se diferenciam dos demais tipos de serviços por não apresentarem uma correspondência imediata entre produto e resultado. Ou seja, os resultados almejados - frutos de vários encontros entre o cliente e o seu fornecedor - ocorrem em um tempo posterior ao da ação efetuada. Em função dessas características e da ausência de uma terminologia própria, foram denominados de Serviços de Resultados Ulteriores (SRU). Considerando-se que os SRUs apresentam características específicas, que demandam práticas gerenciais diferenciadas, neste estudo procura-se compreender tal fenômeno sob o ponto de vista de gerenciamento de operações. Desse modo, o presente trabalho objetiva auxiliar as empresas de SRU - academias de ginástica, serviços sociais de inclusão no mundo do trabalho, cursos preparatórios para concursos, entre outros - a obterem um melhor desempenho. Para tanto, a pesquisa foi baseada na metodologia de estudo de múltiplos casos, e uma mostra de seis diferentes organizações pertencentes às categorias de serviços de massa ou lojas de serviços foi investigada. Os resultados da pesquisa de campo evidenciaram que estas empresas estruturaram um sistema de monitoramento e controle voltado para o relacionamento com os seus clientes, caracterizado por rotinas de acompanhamento dos resultados ulteriores almejados e das atividades realizadas pelo cliente, ao longo de um extenso ciclo de transações. Observou-se também a utilização de táticas que favorecem mais participação e envolvimento dos clientes nas atividades executadas. Verificou-se que aplicação de um sistema de monitoramento e controle bem estruturado afeta positivamente a eficácia dos SRUs, mas ela pode ser influenciada por fatores externos que fogem ao controle da empresa. Além disso, a pesquisa observou que a retenção de clientes é afetada pela capacidade desse sistema de monitoramento e controle apontar necessidades de ajustes e correções em seu processo de entrega de serviço, pois isso favorece benefícios de natureza psicológica e social, além de possibilitar a customização do serviço entregue aos clientes.

Palavras-chave: Serviços de Resultados Ulteriores. Gestão de Operações de Serviços. Desempenho em Serviços. 


\begin{abstract}
This thesis deals with services whose raw material is the customer itself and they differentiate from the others because they do not have an immediate correspondence between the output and the outcome. That is, the outcome is obtained after several service encounters. Due to the fact that this type of service has not been appropriately studied by the service operations management literature and due to the fact that they do not have a proper terminology, them they will be called Services of Posterior Outcomes (SPO). It is important to assert that SPOs presents specific characteristics that require differentiated management practices under the point of view of service operations management, so this thesis intends to help the SPOs companies by understanding how they can achieve better performances. The methodology of case research was used in multiple cases. Six different companies classified as service shop or mass services were analyzed. The field research pointed out that SPOs companies tend to implement a monitoring system oriented for customer relationship. This system is characterized by the presence of routines that monitors the outcomes and the activities carried by the customer on the service, throughout a cycle of transactions. Also, SPO companies use tactics for promoting customer participation and your interest in the services activities. It was verified that a greater presence of this system positively affects the effectiveness of these services, but it is necessary to weigh the influence of external factors that affects the accomplishment of this objective. Moreover, the research observed that the retention of customers is influenced by the capacity of this system to make adjustments and corrections in its process of service delivery, therefore this capacity promote the acquisition of relational benefits by the customers.
\end{abstract}

Keywords: Services of Posterior Outcomes. Service Operations Management. Service Performance. 


\section{LISTA DE FIGURAS}

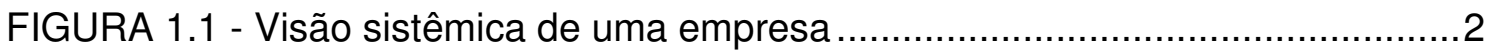

FIGURA 1.2 - Tipos de sistemas conforme a natureza de seus resultados .................

FIGURA 1.3 - Modelo de transformação em um sistema de serviço ...........................5

FIGURA 1.4 - Exemplo da cadeia de impacto na visão de Roche (2002) ...................9

FIGURA 1.5 - Os diferentes tipos de serviços segundo a natureza das saídas

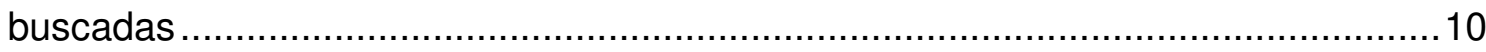

FIGURA 1.6- Dinâmica de surgimento dos resultados ulteriores .............................15

FIGURA 1.7 - Pontos que merecem ser melhor explorados …..............................18

FIGURA 2.1 - Delimitações realizadas e seus respectivos recortes.........................22

FIGURA 3.1 - Entendendo a natureza do serviço prestado ....................................37

FIGURA 3.2 - Relacionamento com os clientes …...............................................38

FIGURA 3.3 - Personalização e julgamento na prestação de serviços ......................38

FIGURA 3.4 - Natureza da demanda e fornecimento ............................................39

FIGURA 3.5 - Método de atendimento em serviços ............................................ 40

FIGURA 3.6 - Classificação de serviços proposta por Schmenner (1986) ...............41

FIGURA 3.7 - Implicações das variáveis diversidade da demanda e disposição do cliente em participar .......................................................................................

FIGURA 3.8 - Tipos de processo de serviço ………......................................50

FIGURA 3.9 - Tipos de processo de serviço em função do volume e variedade .....51

FIGURA 3.10 - Matriz produto-processo em operações de serviço …………..........52

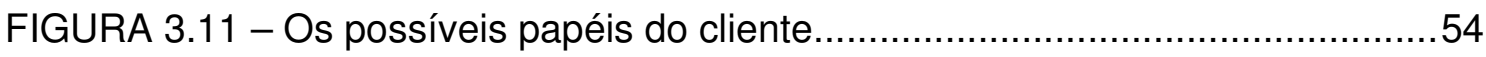

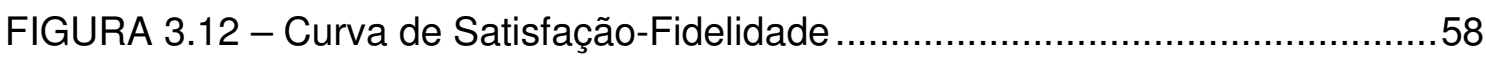

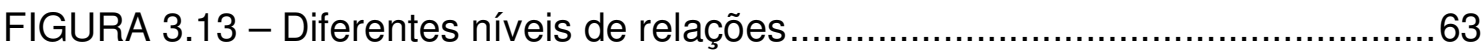

FIGURA 3.14 - Hierarquia das interações que formam o relacionamento da empresa

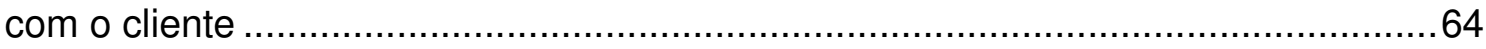

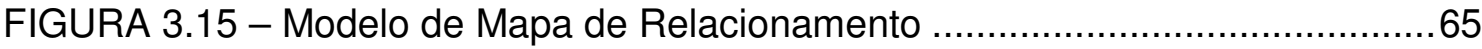

FIGURA 3.16 - Tempo para ocorrência do efeito e complexidade de análise segundo

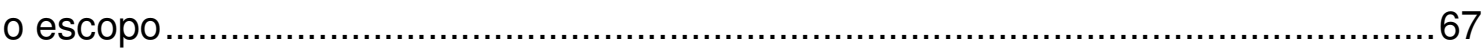

FIGURA 3.17 - Esquema para a apreciação dos fatores externos.............................69

FIGURA 3.18 - Papéis desempenhados pelo cliente nos serviços............................72

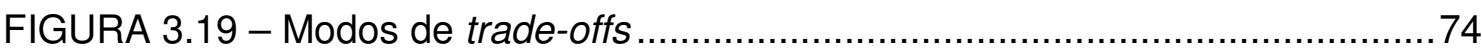

FIGURA 3.20 - Perspectivas estratégias de negócio ..........................................76 
FIGURA 3.21 - Sete critérios para a avaliação do desempenho de um sistema

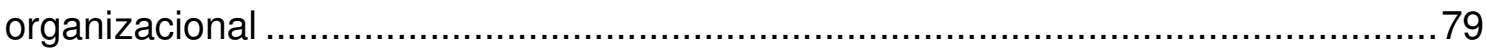

FIGURA 3.22 - Modelo para a produtividade em serviço ......................................84

FIGURA 3.23 - Critérios para a avaliação do desempenho de um sistema organizacional

FIGURA 3.24 - Medição de desempenho no contexto dos diferentes papéis do

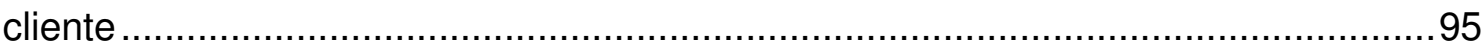

FIGURA 3.25 - Indicadores para medição de desempenho de serviços ...................96

FIGURA 3.26 - O relacionamento das proposições de pesquisa com elementos do framework teórico proposto 98

FIGURA 4.1 - Verificação da proposição de pesquisa por meio gráfico. 110

FIGURA 5.1 - Mapa de relacionamento para o caso AC1 119

FIGURA 5.2 - Principais atividades realizadas no caso AC2. 124

FIGURA 5.3 - Mapa de relacionamento para a grande academia. 127

FIGURA 5.4 - Mapa de relacionamento para os cursos de aperfeiçoamento profissional

FIGURA 5.5 - Mapa de relacionamento para os cursos de aperfeiçoamento profissional para inserção social no mundo do trabalho 143 FIGURA 5.6 - Mapa de relacionamento para o curso preparatório para concurso de vestibular. 150

FIGURA 5.7 - Mapa de relacionamento para os cursos preparatórios de candidatos para concursos em carreiras do direito 157

FIGURA 7.1 - Papéis dos recursos, capacidades e atributos no modelo de trade-off 


\section{LISTA DE GRÁFICOS}

GRÁFICO 5.1 - Quantidade de alunos por horário em dois dias da semana - terçafeira e sexta-feira - estimando-se um tempo de permanência de 75 minutos no local

GRÁFICO 6.1 - Sistema de monitoramento nos casos AC1 e AC2 168

GRÁFICO 6.2 - Uso de táticas que estimulam o envolvimento e a participação dos clientes nos casos AC1 e AC2 169

GRÁFICO 6.3 - Sistema de monitoramento nos casos SS1 e SS2. 171 GRÁFICO 6.4 - Uso de táticas que estimulam o envolvimento e a participação dos

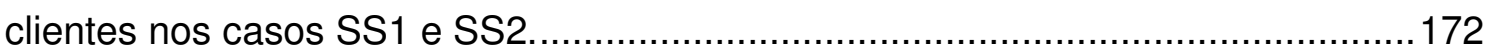

GRÁFICO 6.5 - Sistema de monitoramento nos casos CP1 e CP2 . 174 GRÁFICO 6.6 - Uso de táticas que estimulam o envolvimento e a participação dos clientes nos casos CP1 e CP2 175

GRÁFICO 6.7 - Grau de adoção da prática de seleção dos clientes nos casos estudados.

GRÁFICO 6.8 - Resultados de eficácia nas diferentes empresas/entidades analisadas.

GRÁFICO 6.9 - Resultados para taxa de retenção nas diferentes empresas/entidades analisadas.

GRÁFICO 6.10 - Resultados para a freqüência nas diferentes empresas/entidades

analisadas. 189

GRÁFICO 7.1 - Valores de eficácia e grau de aplicação do sistema de monitoramento e controle. 195

GRÁFICO 7.2 - Resultados de eficácia e o grau de aplicação das características e práticas referentes ao sistema de monitoramento e controle. 195

GRÁFICO 7.3 - Valores de eficácia e grau de adoção de táticas que possam favorecer maior participação e envolvimento dos clientes nas atividades. GRÁFICO 7.4 - Resultados de eficácia e grau de adoção de táticas que possam favorecer maior participação e envolvimento dos clientes nas atividades. 198 GRÁFICO 7.5 - Valores de retenção e grau de aplicação das características e práticas referentes à segunda fase do sistema de monitoramento e controle. 
GRÁFICO 7.6 - Resultados de retenção e grau de aplicação das características e práticas referentes à segunda fase do sistema de monitoramento e controle. .......199 


\section{LISTA DE QUADROS}

QUADRO 1.1 - Exemplo para os cinco aspectos do serviço de uma clínica médica 6 QUADRO 1.2 - Exemplo da adoção de uma avaliação multicritério do produto e de seu desempenho nos correios da França (atividade: correspondência) 8

QUADRO 1.3 - Termos e significados para serviços que objetivam primordialmente atingir os resultados indiretos de seus processos 11

QUADRO 1.4 - Níveis de participação dos clientes em diferentes serviços ..............13

QUADRO 1.5 - Estrutura da tese ...................................................................

QUADRO 3.1 - As diferentes definições de serviço .............................................28

QUADRO 3.2 - As diferenças entre manufatura e serviço .......................................29

QUADRO 3.3 - As diferenças clássicas entre manufatura e serviço .........................30

QUADRO 3.4 - A aplicabilidade das características diferenciadoras dos serviços em

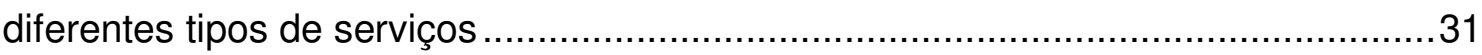

QUADRO 3.5 - Diferentes classificações de serviços .............................................33

QUADRO 3.6 - Definição de Murdock das classes de serviços .................................34

QUADRO 3.7 - Tipologia de Walker sobre as funções de serviços............................34

QUADRO 3.8 - Classificação de Marshall sobre serviços às empresas.....................34

QUADRO 3.9 - Classificação de serviços segundo funções ....................................35

QUADRO 3.10 - Classificação de serviços considerando o esforço do consumidor

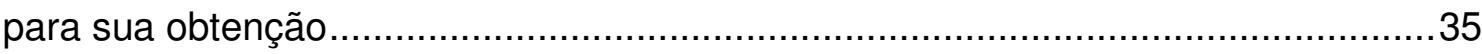

QUADRO 3.11 - Classificação de serviços proposta por Chase (1978) ....................36

QUADRO 3.12 - Tipologia de serviços proposta por Wemmerlöv (1990).................47

QUADRO 3.13 - Prescrições segundo as características de processo …………......48

QUADRO 3.14 - Objetivos/critérios competitivos para operações de serviços ........73

QUADRO 3.15 - Exemplos referentes aos três critérios de indicadores nos três

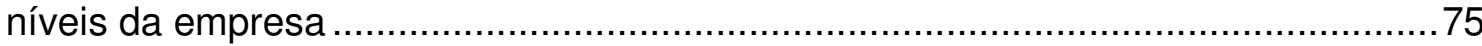

QUADRO 3.16 - Possíveis indicadores para a perspectiva de processos internos..77

QUADRO 3.17 - Possíveis indicadores para a perspectiva de aprendizado e

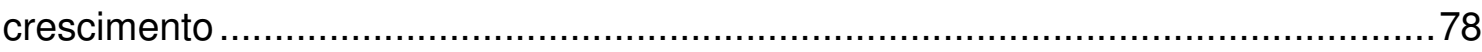

QUADRO 3.18 - Roteiro para definição de um indicador ...................................... 88

QUADRO 3.19 - Sistema de monitoramento e controle .......................................91 
QUADRO 3.20 - Características a serem avaliadas no sistema de monitoramento

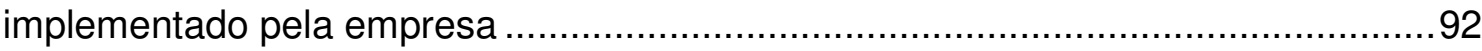

QUADRO 4.1 - Os diferentes estágios do desenvolvimento de uma teoria .............101

QUADRO 4.2 - Caracterização da natureza da pesquisa ....................................103

QUADRO 4.3 - Testes e táticas para julgar a qualidade do projeto de pesquisa realizado através de estudo de caso...................................................................105

QUADRO 4.4 - Pontos para análise considerados na pesquisa............................106

QUADRO 4.5 - Verificação da proposição por meio gráfico ………………….......108

QUADRO 5.1 - Serviços oferecidos por academias de ginástica ............................115

QUADRO 5.2 - Atividades registradas no sistema de monitoramento no caso AC1

QUADRO 5.3 - Atividades registradas no sistema de monitoramento no caso AC2

QUADRO 5.4 - Atividades registradas, sua duração, quantidade de pessoas

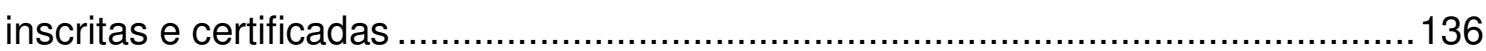

QUADRO 5.5 - Visões a respeito do jovem com necessidades especiais ...........139 QUADRO 5.6 - Atividades registradas pelo curso preparatório para o vestibular ..151 QUADRO 5.7 - Atividades realizadas pelo curso preparatório para carreiras em direito 158

QUADRO 6.1 - Tipo de estimação para o cálculo do desempenho nas diferentes empresas pesquisadas

QUADRO 6.2 - Práticas de seleção e diagnóstico de clientes nas diferentes empresas/entidades

QUADRO 6.3 - Rotinas de coleta e análise dos dados nas diferentes empresaslentidades 184

QUADRO 6.4 - Adoção de táticas que estimulam o envolvimento e a participação dos clientes pelas diferentes empresas 185 


\section{LISTA DE TABELAS}

TABELA 5.1 - Taxas de Cancelamento e Retenção para a Grande Academia de Ginástica 162

TABELA 5.2 - Resultados de desempenho nas diferentes empresas/entidades analisadas.

TABELA 6.1 - Grau de aplicação do sistema de monitoramento nas empresas/entidades pesquisadas 180

TABELA 6.2 -Fatores externos que impactam a eficácia nas diferentes empresas 181 


\section{LISTA DE ABREVIATURAS E SIGLAS}

AA Alcoólicos Anônimos

AC1 Caso referente a uma academia de ginástica - atividades de musculação

AC2 Caso referente a uma grande academia de ginástica - atividades de musculação

B2B Business to Business

BICA Buscando Integração pela Arte

BSC Balanced Scorecard

CDL Clube de Diretores Lojistas

CP1 Caso referente a um curso preparatório para concurso de vestibular

CP2 Caso referente a um curso preparatório para concursos públicos na área de direito

Nepro Núcleo de Educação Profissional

ONG Organização Não-Governamental

ONU Organização das Nações Unidas

PEPS Primeiro que Entra, Primeiro que Sai

PUC-MG Pontifícia Universidade Católica de Minas Gerais

SPA Estabelecimento que reúne serviços de hotelaria e outros, terapêuticos ou de cuidados corporais

SRU Serviço de Resultado Ulterior

SS1 Caso referente a cursos de aperfeiçoamento profissional para recolocação e re-inserção social

SS2 Caso referente a cursos de aperfeiçoamento profissional para inserção social de jovens com necessidades especiais no mundo do trabalho

UFMG Universidade Federal de Minas Gerais 


\section{SUMÁRIO}

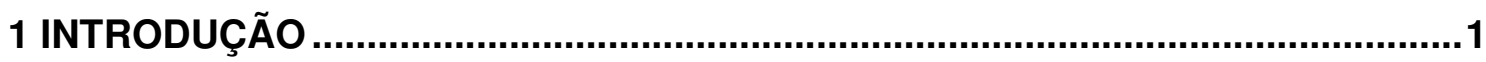

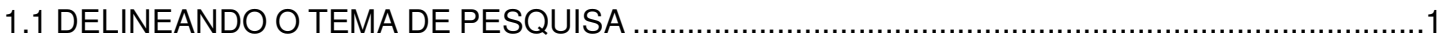

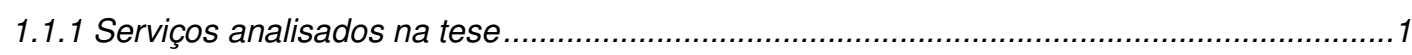

1.1.2 Pontos sobre SRU que merecem ser melhor explorados ................................................12

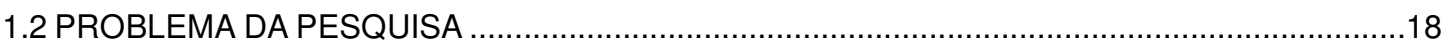

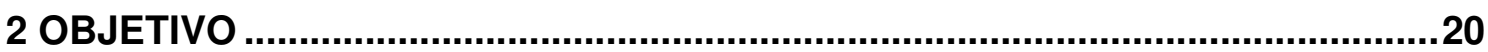

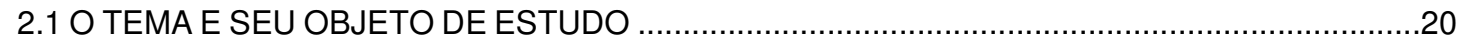

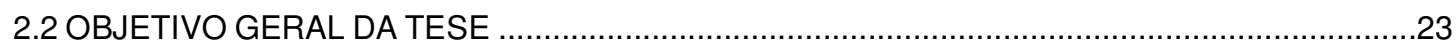

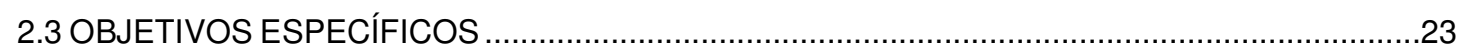

2.4 QUESTÕES DE PESQUISA E PROPOSIÇÕES A SEREM VERIFICADAS ...............................24

3 REFERENCIAL TEÓRICO_.......................................................................26

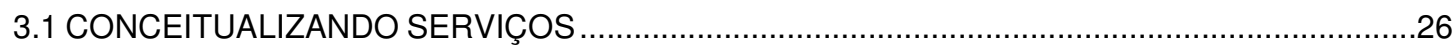

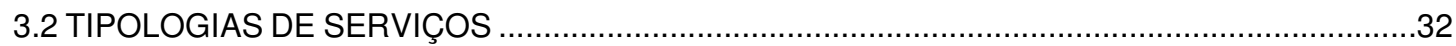

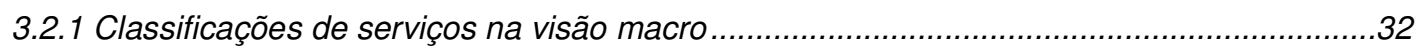

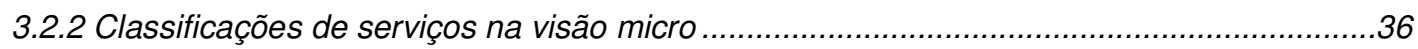

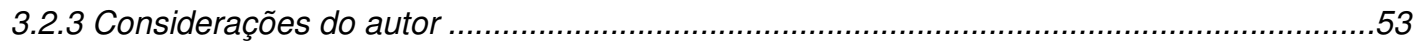

3.3 CARACTERÍSTICAS DOS SERVIÇOS DE RESULTADOS ULTERIORES POR MEIO DOS

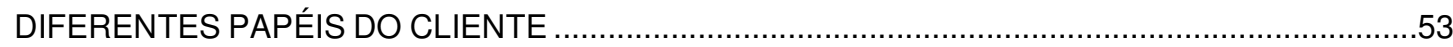

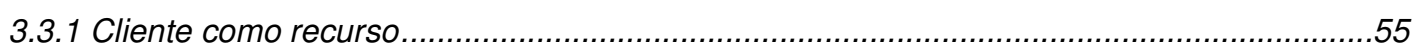

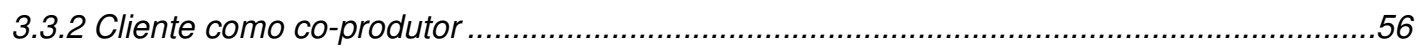

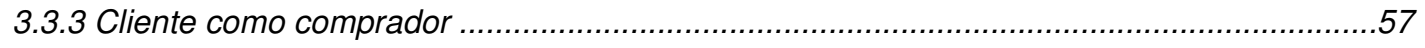

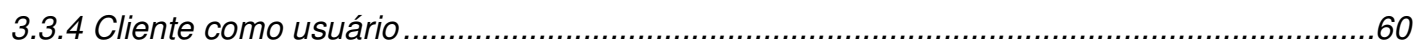

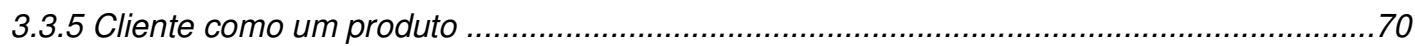

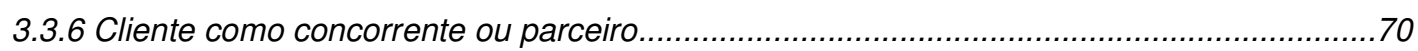

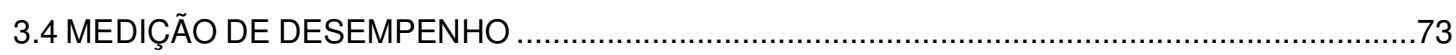

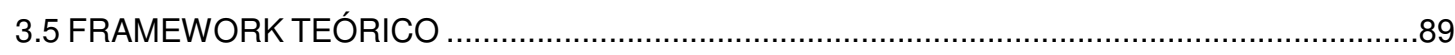

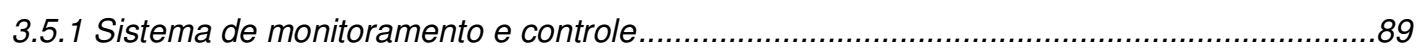

3.5.2 Táticas que estimulam o envolvimento e a participação dos clientes.................................93

3.5.3 Desempenho do serviço..........................................................................................95

3.5.4 As Proposições de pesquisa e o Framework Teórico .........................................................98 
4 METODOLOGIA DE PESQUISA

4.1 POSICIONANDO O TEMA DE PESQUISA NO ESTÁGIO DE DESENVOLVIMENTO DA TEORIA 102

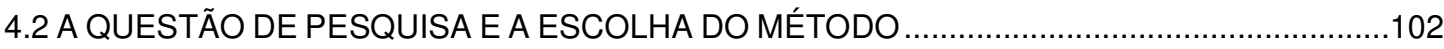

4.3 O PROCESSO DE CONDUÇÃO DO ESTUDO DE CASO

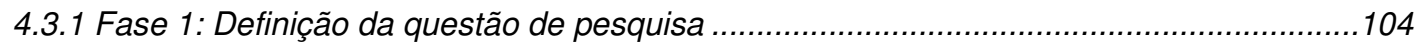

4.3.2 Fase 2: Desenvolvimento do instrumento de pesquisa e seleção da amostra...................104

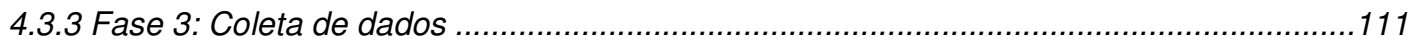

4.3.4 Fases 4 e 5: Análise dos dados e divulgação ............................................................112

5 DESCRIÇÃO DOS CASOS ............................................................................114

5.1 CASO 1: ACADEMIA DE GINÁSTICA - ATIVIDADES DE MUSCULAÇÃO (AC1) ....................114

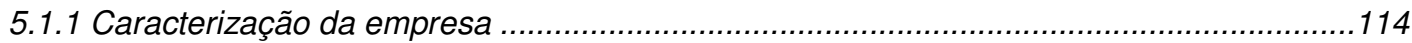

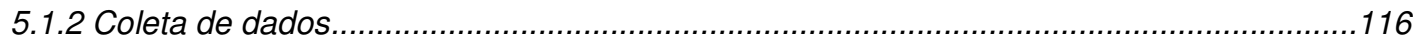

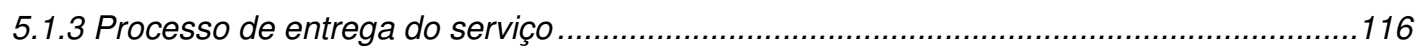

5.1.4 Sistema de monitoramento e controle dos clientes........................................................117

5.1.5 Táticas que estimulam o envolvimento e a participação dos clientes................................121

5.2 CASO 2: GRANDE ACADEMIA DE GINÁSTICA - ATIVIDADES DE MUSCULAÇÃO (AC2) ....123

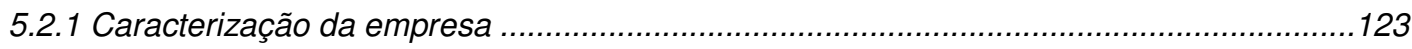

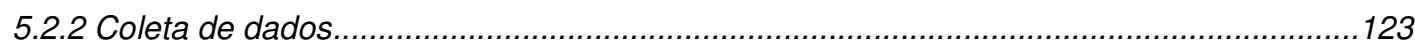

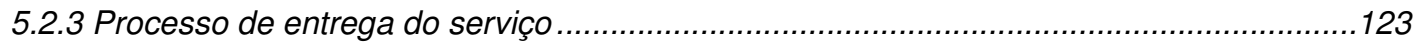

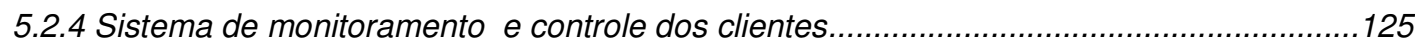

5.2.5 Táticas que estimulam o envolvimento e a participação dos clientes...............................129

5.3 CASO 3: CURSOS DE APERFEIÇOAMENTO PROFISSIONAL PARA RECOLOCAÇÃO E

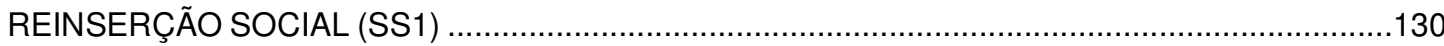

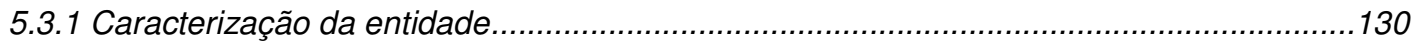

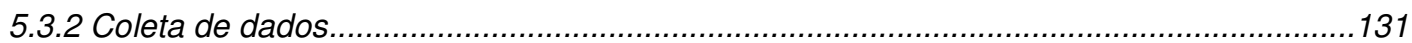

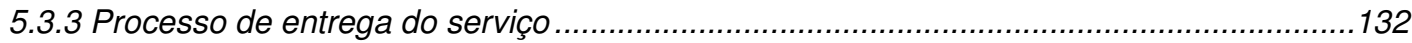

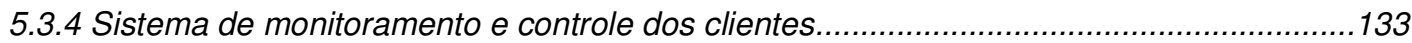

5.3.5 Táticas que estimulam o envolvimento e a participação dos clientes................................137

5.4 CASO 4: CURSOS DE APERFEIÇOAMENTO PROFISSIONAL PARA INSERÇÃO SOCIAL NO

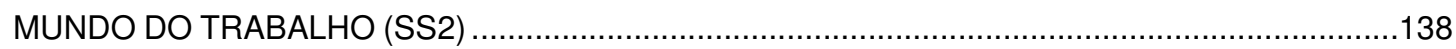

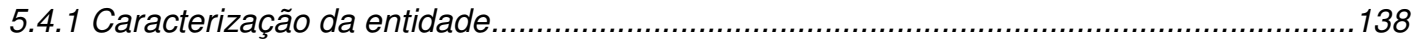

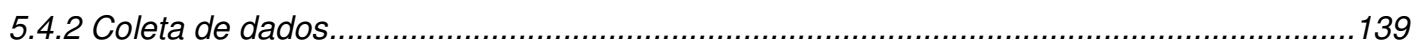

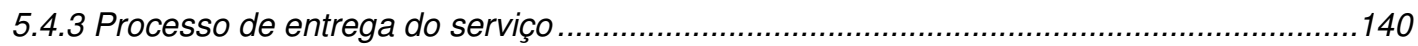

5.4.4 Sistema de monitoramento e controle dos clientes.........................................................141 
5.4.5 Táticas que estimulam o envolvimento e a participação dos clientes................................145

5.5 CASO 5: CURSO PREPARATÓRIO PARA CONCURSO DE VESTIBULAR (CP1) ..................147

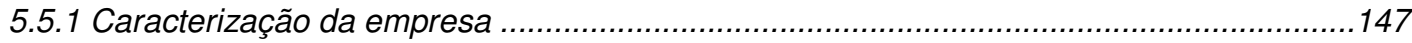

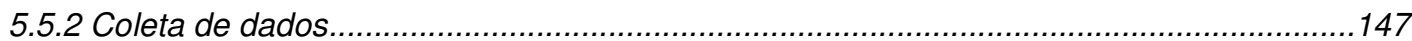

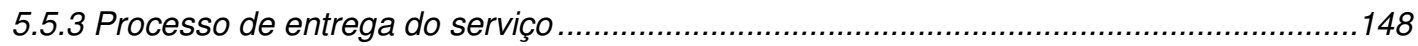

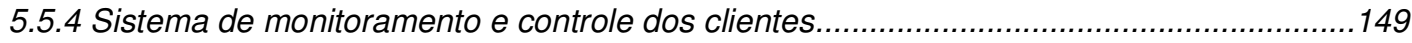

5.5.5 Táticas que estimulam o envolvimento e a participação dos clientes.................................152

5.6 CASO 6: CURSO PREPARATÓRIO PARA CONCURSOS EM CARREIRAS DO DIREITO (CP2)

153

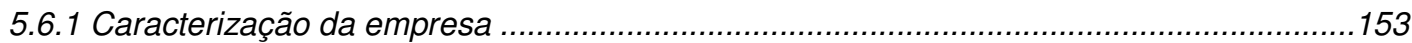

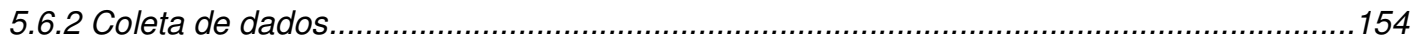

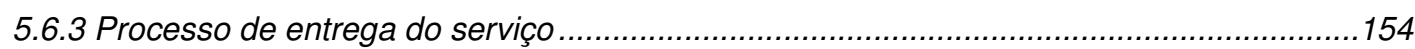

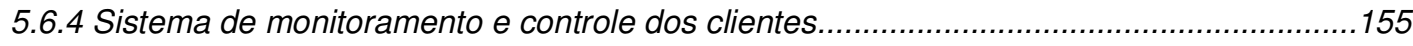

5.6.5 Táticas que estimulam o envolvimento e a participação dos clientes................................159

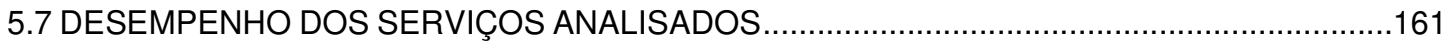

5.7.1 AC1 - Academia de ginástica - atividades de musculação …...........................................161

5.7.2 AC2 - Grande academia de ginástica - atividades de musculação ...................................162

5.7.3 SS1 - Cursos de aperfeiçoamento profissional para recolocação e reinserção social......163

5.7.4 SS2 - Cursos de aperfeiçoamento profissional para inserção social no mundo do trabalho

5.7.5 CP1 - Curso preparatório para concurso de vestibular .....................................................164

5.7.6 CP2 - Curso preparatório para concursos em carreiras do direito........................................165

5.7.7 Síntese da avaliação de indicadores de desempenho ...................................................166

6 ANÁLISE E DISCUSSÃO DOS RESULTADOS.................................................167

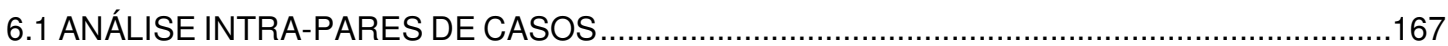

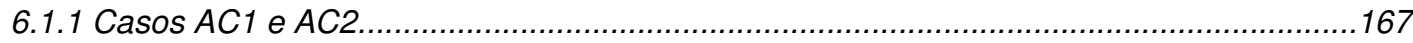

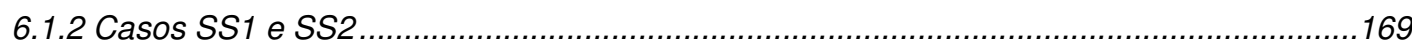

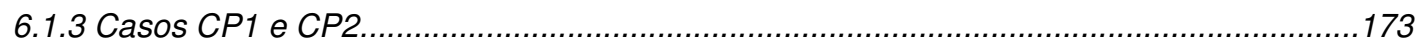

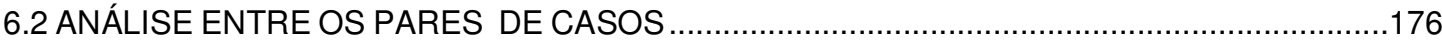

6.3 ANÁLISE ENTRE ENTIDADES SEM FINS LUCRATIVOS E EMPRESAS QUE VISAM AO

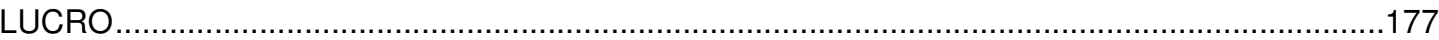

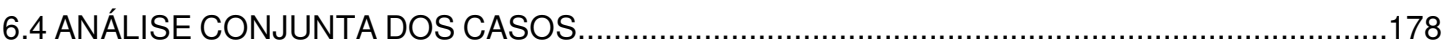

6.4.1 Sistema de monitoramento e controle nas empresas/entidades ...................................179

6.4.2 Táticas que estimulam o envolvimento e a participação dos clientes................................185

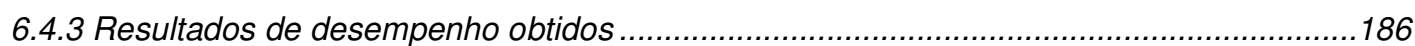

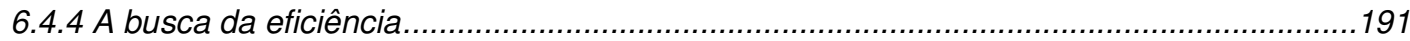




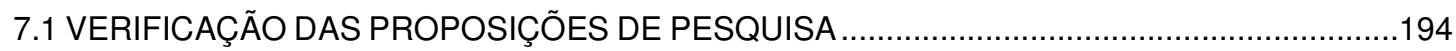

7.1.1 A primeira proposição e os resultados encontrados ..........................................................194

7.1.2 A segunda proposição e os resultados encontrados .......................................................197

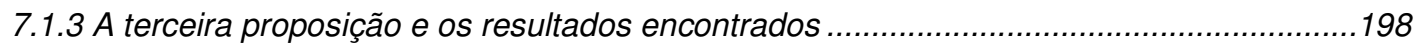

7.2 CONTRIBUIÇÕES SECUNDÁRIAS DO TRABALHO

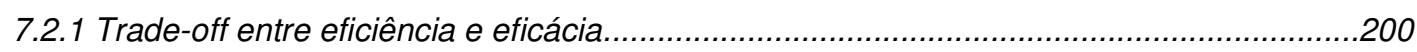

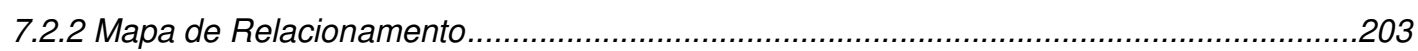

7.2.3 Meio para avaliação do sistema de monitoramento em SRUs .......................................204

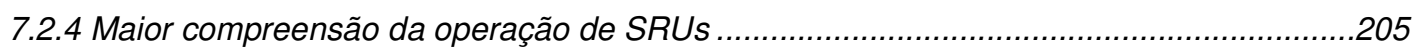

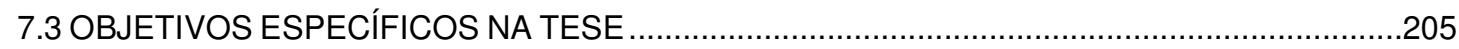

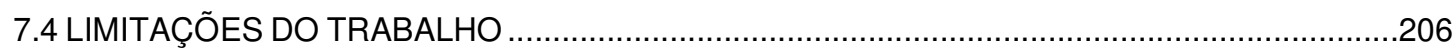

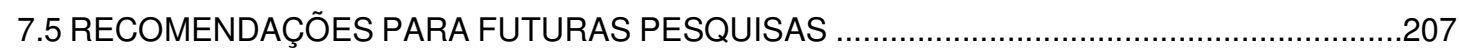

REFERÊNCIAS BIBLIOGRÁFICAS ..............................................................209

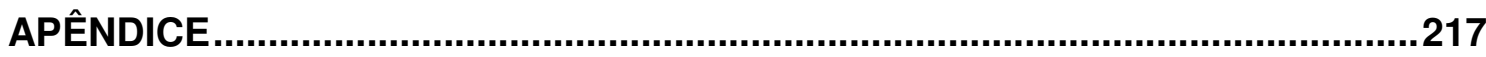

ANEXOS 


\section{INTRODUÇÃO}

\subsection{DELINEANDO O TEMA DE PESQUISA}

Apesar da sua presença e importância em nossa sociedade, os serviços ainda necessitam de uma melhor compreensão. Neste sentido, Slack; Lewis e Bates (2004), e Slack (2005) analisam como tem caminhado a pesquisa na área de gerenciamento de operações nos últimos anos. Estes autores confrontaram temas pesquisados pela comunidade acadêmica e aqueles percebidos como importantes pelos praticantes da área e relata que o setor de serviços, apesar de representar a maior parcela da atividade econômica tanto nos Estados Unidos como no Reino Unido, foi abordado por apenas cerca de $10 \%$ da pesquisa em gerenciamento de operações. Tais dados foram constatados a partir de uma análise dos trabalhos desenvolvidos em dois periódicos, International Journal of Operations \& Production Management e Journal of Operations Management, durante os anos de 2000 a 2003.

Diante desse quadro, a presente tese pretende contribuir para que o setor de serviços seja melhor compreendido. Para tanto, restringe seu objeto de estudo somente à categoria de serviços que buscam, primordialmente, os efeitos de seus produtos, ou seja, seus resultados ulteriores.

\subsubsection{Serviços analisados na tese}

Visando esclarecer o tipo de serviço tratado neste trabalho, alguns conceitos fundamentais serão expostos. Primeiramente, eles serão definidos sob a perspectiva da teoria geral dos sistemas. Posteriormente, serão descritos sob a lógica da abordagem por processos. 
Segundo a perspectiva da visão sistêmica, toda organização contém sistemas a montante e a jusante e, naturalmente, as interfaces com os mesmos. Nessa perspectiva, toda organização tem clientes, "fornecedores e vendedores", sistemas ou pessoas de quem recebe inputs e a quem fornece outputs. Todo sistema organizacional tem inputs, atividades ou processos de transformação que acrescentam valor, outputs ${ }^{1}$ e resultados ${ }^{2}$, conforme ilustra a Figura 1.1 (SINK e TUTLE, 1993).

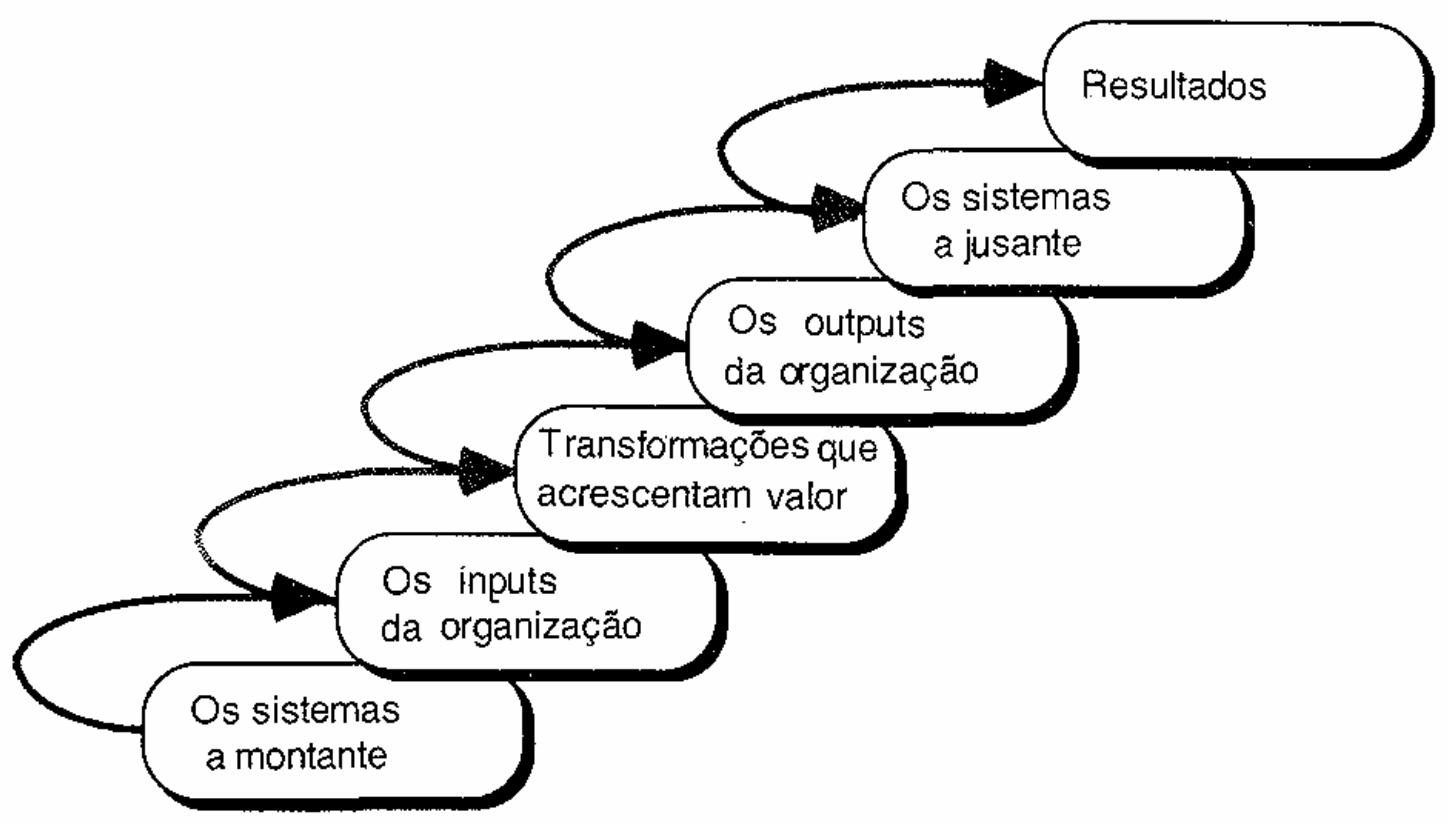

FIGURA 1.1 - Visão sistêmica de uma empresa

Fonte: Figura 5.12 de Sink e Tuttle (1993)

Ainda sob essa visão, podem-se dividir as organizações por seus resultados. Neste enfoque, consideram-se sistemas que geram resultados de três tipos diferentes, conforme enumerados a seguir:

- sistema de resultados diretos - o output praticamente garante 0 resultado, onde o resultado segue o output com alto grau de certeza;

- sistema de resultados indiretos - a variabilidade dos outputs é bem maior, e apenas alguns deles produzirão os resultados mais favoráveis;

\footnotetext{
${ }_{1}^{1}$ Output ou produto: aquilo que resulta de qualquer processo ou atividade

${ }^{2}$ Resultado pode ser entendido como conseqüência ou efeito de um produto.
} 
- sistema de resultados desconhecidos - a compreensão da ligação entre o output e o resultado não é perfeita, provavelmente não é visível ou passível de ser conhecida, ou ainda, pode existir uma grande defasagem de tempo entre o output e o resultado. A Figura 1.2 ilustra estes três tipos de sistemas (SINK e TUTTLE, 1993).

\section{Sistema de resultados diretos}

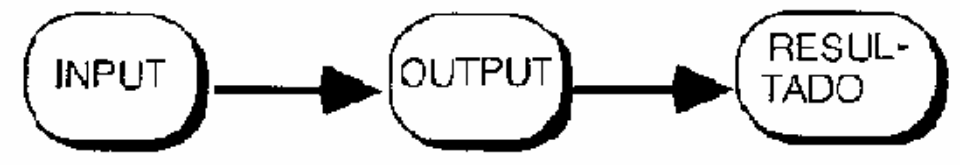

\section{Sistema de resultados indiretos}

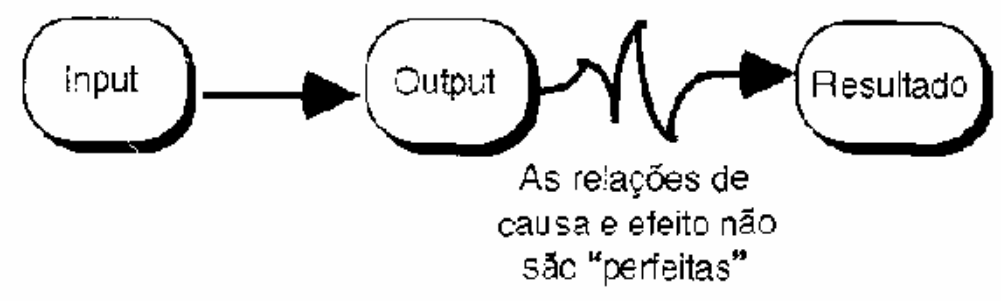

\section{Sistema de resultados desconhecidos}

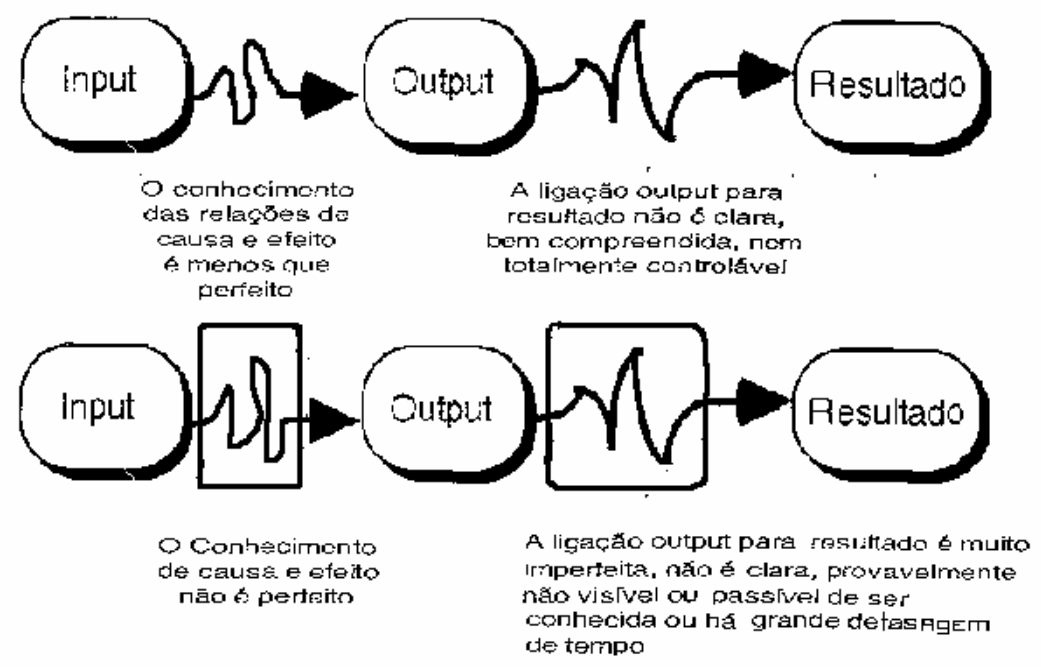

FIGURA 1.2 - Tipos de sistemas conforme a natureza de seus resultados Fonte: Adaptada das Figuras 5.15, 5.16 e 5.17 de Sink e Tuttle (1993) 
Tomando-se essa classificação como referência, o presente trabalho lida com os serviços que se enquadram como sistemas de resultados indiretos ou desconhecidos.

Para que esse tipo de serviço seja mais bem compreendido, é necessário refleti-lo como um processo de transformação. Nesse sentido, Haksever et al. (2000); Lovelock e Yip (1996); Lovelock e Gummeson (2004); Slack et al. (2001) e Wemmerlöv (1990) utilizam o modelo de transformação para descrever a criação dos serviços. Colocam estes como resultado de um processo de transformação. Neste modelo, todas as operações usam recursos para mudar o estado ou a condição de algo, produzindo produtos ou outputs, sejam eles serviços ou bens. Baseando-se nas características comuns dos processos operacionais, Lovelock e Yip (1996) classificaram os serviços em três categorias:

- serviços que têm como objeto principal do processo as próprias pessoas: "atos físicos nas próprias pessoas" e que envolvem cada cliente diretamente na entrega dos serviços. Nestes serviços, a produção e o consumo são simultâneos. Ou os clientes se dirigem ao prestador de serviço ou o prestador de serviço deve ir até os clientes. Exemplos: transporte de passageiros, clínicas de saúde, restaurantes, etc;

- serviços que têm como objeto principal do processo as posses: "atos físicos nos objetos físicos" das pessoas. Os itens a serem processados precisam estar envolvidos no processo de serviço, mas os clientes, necessariamente, não. Exemplos: transportadoras, instalação e manutenção de equipamentos, lavanderias, etc;

- serviços baseados na informação, cujos objetos transformados são as mentes das pessoas ou as informações: dirigem-se às mentes das pessoas (processamento de estímulo mental) ou a seus ativos intangíveis (processamento de informações). O envolvimento dos clientes na produção pode ser mínimo. O uso da tecnologia da informação permite a realização de alguns desses serviços de modo remoto. Exemplos: bancos, consultoria, educação, entretenimento, jornais, etc. 
Aplicando esse modelo de transformação aos serviços, verifica-se que o cliente torna-se o elemento comum aos diferentes processos de criação, na medida em que todos devem processar o próprio cliente e/ou suas posses, sejam elas informações ou bens, conforme observado na Figura 1.3.

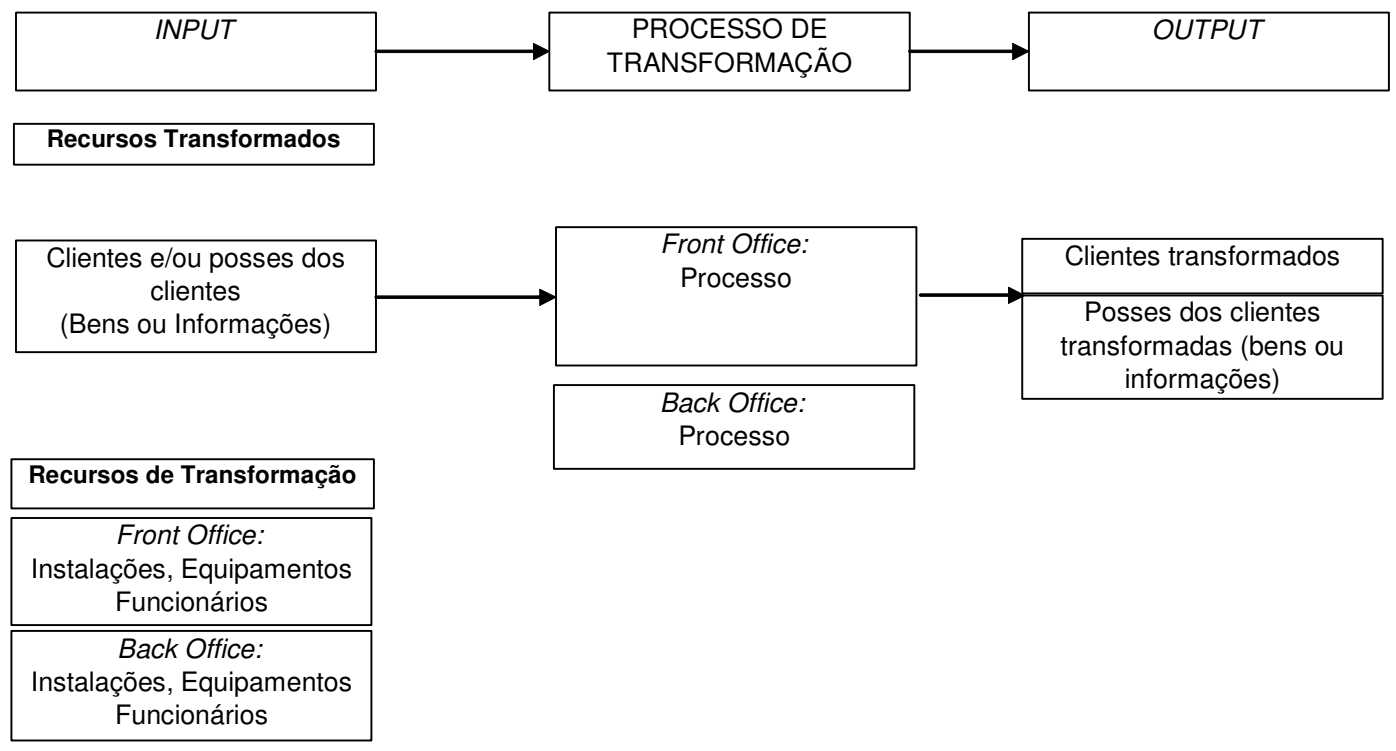

FIGURA 1.3 - Modelo de transformação em um sistema de serviço

Fonte: baseada em Haksever et al. (2000); Lovelock e Yip (1996); Lovelock e Gummeson (2004); Slack et al. (2001) e Wemmerlöv (1990).

O modelo de transformação é formado por três elementos: input, processo e output. Explorando mais esses elementos e adotando uma perspectiva mais ampla, Fitzsimmons e Fitzsimmons (2000) revelam cinco pontos presentes nestes três elementos, que são relevantes para a obtenção de um serviço de qualidade. São eles:

- a estrutura: refere-se às instalações físicas e ao projeto organizacional existente. Está diretamente relacionada com o input no modelo de transformação. Os autores argumentam que a qualidade pretendida pelo serviço deve ser suportada por uma infra-estrutura física apropriada, além de contar com um quadro adequado e qualificado de funcionários;

- o processo: refere-se à seqüência das atividades realizadas para a prestação do serviço. Está diretamente relacionado com o modelo de transformação. A 
organização deve manter uma seqüência lógica de atividades e utilizar, de modo ordenado, os recursos para a realização dos serviços. As interações entre o cliente e o pessoal encarregado necessitam de monitoramento. Também são de interesse as interações e as comunicações entre os trabalhadores encarregados;

- o conteúdo: refere-se aos padrões utilizados para execução das atividades no processo. Está diretamente relacionado com o processo no modelo de transformação. Os autores observam que os procedimentos estabelecidos devem ser seguidos e estar de acordo com as boas práticas do setor ou da área de conhecimento afim, para que a sua qualidade seja obtida;

- o resultado: refere-se à mudança ocorrida logo após a entrega do serviço. Está diretamente relacionado com o output no modelo de transformação. Os autores ressaltam a importância da avaliação dos resultados obtidos, a fim de avaliar, de modo realista, a sua qualidade;

- o impacto: refere-se ao efeito do resultado do serviço e pode atingir um grupo maior de pessoas. Pode ser entendido como desdobramento do output no modelo de transformação. Os autores também mencionam que o impacto do serviço deve contemplar a dimensão de acessibilidade ${ }^{3}$ ao serviço.

Fitzsimmons e Fitzsimmons (2000) exemplificam esses elementos para o serviço de uma clínica médica, conforme apresentado no Quadro 1.1. Sob a ótica destes autores, o output pode ser decomposto em resultados e impactos. Entretanto, reconhecem a dificuldade de definir e mensurar tais itens em prestação de serviços.

\begin{tabular}{|l|l|}
\hline Componentes & Descrição \\
\hline Conteúdo & A prática médica adotada deve seguir as boas práticas existentes na área. \\
\hline Processo & $\begin{array}{l}\text { A seqüência de eventos na prestação do serviço de saúde e as interações entre } \\
\text { pacientes e a equipe médica. }\end{array}$ \\
\hline Estrutura & $\begin{array}{l}\text { As instalações físicas, os equipamentos, o quadro de funcionários, e as qualificações } \\
\text { do pessoal da saúde. }\end{array}$ \\
\hline Resultado & A mudança no estado de saúde do paciente como resultado do serviço de saúde. \\
\hline Impacto & $\begin{array}{l}\text { Adequação, disponibilidade, acessibilidade, e efeito total da clínica de saúde sobre a } \\
\text { comunidade. }\end{array}$ \\
\hline
\end{tabular}

QUADRO 1.1 - Exemplo para os cinco aspectos do serviço de uma clínica médica Fonte: Baseado na Tabela 10.3 em Fitzsimmons e Fitzsimmons (2000)

\footnotetext{
${ }^{3}$ É entedida como a facilidade de acesso (localização conveniente) e de contato do cliente para com o serviço.
} 
O output do serviço é discutido também por Gadrey (2001), ao expor a necessidade de se discutir o que constitui o seu produto. Este autor advoga a necessidade de ir além da lógica industrial, que não leva em consideração o caráter plural do produto do serviço. De acordo com ele, considerando lapsos temporais mais ou menos longos, pode-se, em curto prazo, distinguir produtos imediatos e diretos. Nos horizontes mais longos, distinguem-se os produtos indiretos, ou seja, impactos do serviço ou seus resultados ulteriores. Inúmeros deles visam melhorar ou restabelecer a situação de uma dada realidade, preocupando-se mais com os produtos indiretos. Para Gadrey (2001), ao se focalizar apenas os produtos imediatos, privilegia-se o desempenho técnico, do tipo industrial. Ele sugere a adoção mais ampla de critérios para avaliação do produto e dos desempenhos em uma atividade de serviço como um meio para se determinar de modo mais justo o seu desempenho. Em sua visão, podem-se incorporar, tanto para os produtos e resultados diretos da atividade como para os produtos e resultados indiretos, seis critérios de julgamento sobre o valor e a quantidade do produto da atividade:

- critérios técnicos ou industriais;

- critérios comerciais e financeiros;

- critérios de relacionamento;

- critérios cívicos;

- critérios de criatividade ou de inovação;

- critérios de imagem e de reputação.

Como exemplo, Gadrey (2001) cita a adoção de quatro destes critérios nos correios na França, conforme apresentado no Quadro 1.2.

De modo mais específico, Roche (2002) discute o papel e as diferentes maneiras de se mensurar o impacto de serviços sociais realizados por ONGs. $O$ autor destaca que, a partir da década de 1950, as agências de desenvolvimento tentavam prever, antes do início de um projeto, suas prováveis conseqüências ambientais, sociais e econômicas, para aprová-lo, ajustá-lo ou rejeitá-lo. Define de modo claro e mais preciso o que vem a ser o impacto: são mudanças duradouras ou significativas - positivas ou negativas, planejadas ou não - na vida das pessoas e ocasionadas por determinada ação ou série de ações. 


\begin{tabular}{|c|c|c|c|c|}
\hline $\begin{array}{l}\text { Critérios construtivos } \\
\text { do valor e da } \\
\text { quantidade de } \\
\text { produto }\end{array}$ & $\begin{array}{l}\text { Critérios técnicos ou } \\
\text { industriais }\end{array}$ & $\begin{array}{l}\text { Critérios comerciais } \\
\text { e financeiros }\end{array}$ & $\begin{array}{l}\text { Critérios de } \\
\text { relacionamento }\end{array}$ & $\begin{array}{l}\text { Critérios } \\
\text { cívicos }\end{array}$ \\
\hline $\begin{array}{l}\text { Caso da análise do } \\
\text { "produto direto" e de } \\
\text { seu desempenho }\end{array}$ & $\begin{array}{l}\text { Quantidades } \\
\text { coletadas, triadas, } \\
\text { distribuídas } \\
\text { (apreciação via } \\
\text { complexidade do } \\
\text { tráfego). } \\
\\
\text { Desempenho = } \\
\text { ganhos de } \\
\text { produtividade + } \\
\text { qualidade "industrial" } \\
\text { (prazos, estoques, } \\
\text { taxa de erros). }\end{array}$ & $\begin{array}{l}\text { Receitas segundo } \\
\text { correspondências, } \\
\text { valor agregado, } \\
\text { margens,custos } \\
\text { médios. } \\
\text { Desempenho = } \\
\text { melhoria dos } \\
\text { indicadores de } \\
\text { "saúde financeira" } \\
\text { Competitividade } \\
\text { perante os } \\
\text { concorrentes. }\end{array}$ & $\begin{array}{l}\text { Respostas } \\
\text { personalizadas, } \\
\text { composições } \\
\text { interpessoais, } \\
\text { confiança. } \\
\\
\text { Aconselhamento } \\
\text { personalizado. } \\
\text { Desempenho = } \\
\text { melhoria da } \\
\text { qualidade do } \\
\text { relacionamento no } \\
\text { serviço. }\end{array}$ & $\begin{array}{l}\text { Trato justo das } \\
\text { pessoas (no } \\
\text { atendimento em } \\
\text { guichês ou nas } \\
\text { visitas aos clientes). } \\
\text { Assistência às } \\
\text { populações } \\
\text { desfavorecidas. } \\
\text { Acessibilidade } \\
\text { (eqüidade). } \\
\text { Desempenho = } \\
\text { melhoria das } \\
\text { qualidades cívicas } \\
\text { do serviço. }\end{array}$ \\
\hline $\begin{array}{l}\text { Caso da análise dos } \\
\text { efeitos e resultados } \\
\text { indiretos e de seu } \\
\text { desempenho }\end{array}$ & $\begin{array}{l}\text { Contribuição da } \\
\text { atividade } \\
\text { "correspondência" } \\
\text { dos correios ao } \\
\text { crescimento } \\
\text { econômico (nacional, } \\
\text { local), à eficiência de } \\
\text { outras empresas e } \\
\text { setores. }\end{array}$ & $\begin{array}{l}\text { Contribuição à } \\
\text { rentabilidade das } \\
\text { empresas clientes, à } \\
\text { redução de seus } \\
\text { custos. } \\
\text { Domínio das } \\
\text { condições } \\
\text { financeiras do } \\
\text { desenvolvimento } \\
\text { econômico de longo } \\
\text { prazo. }\end{array}$ & \begin{tabular}{|l|} 
Geração de \\
comportamentos de \\
fidelidade (à \\
empresa ou aos \\
seus agentes). \\
\\
Inserção durável da \\
organização nas \\
redes locais.
\end{tabular} & \begin{tabular}{|l} 
Contribuição à \\
solidariedade \\
nacional ou local, à \\
redução das \\
desigualdades. \\
Contribuição ao \\
planejamento do \\
espaço, ao \\
desenvolvimento \\
local e ao meio \\
ambiente.
\end{tabular} \\
\hline
\end{tabular}

QUADRO 1.2 - Exemplo da adoção de uma avaliação multicritério do produto e de seu desempenho nos correios da França (atividade: correspondência)

Fonte : Grade 2 de Gadrey (2001)

Roche (2002) observa que os efeitos em curto, médio e longo prazos dos produtos das atividades ou processos de prestação de serviço formam uma cadeia de impacto, conforme indica o exemplo sobre conscientização dos direitos jurídicos da Figura 1.4. Para ocorrer o curso de treinamento, os organizadores devem fazer seu trabalho e os recursos devem estar disponíveis. Os resultados dependem não apenas dos instrutores, mas também da capacidade e especialidade dos alunos, bem como da sua participação e desejo de aprender. No nível do impacto, a habilidade das pessoas de usar o sistema legal e de tirar proveito dele depende, por sua vez, de como o sistema legal funciona. Segundo o autor, ao partirmos dos 
produtos em direção aos resultados, e dos resultados aos impactos, tornam-se crescentes as influências dos contextos, sejam eles social, econômico, ambiental e/ou político.
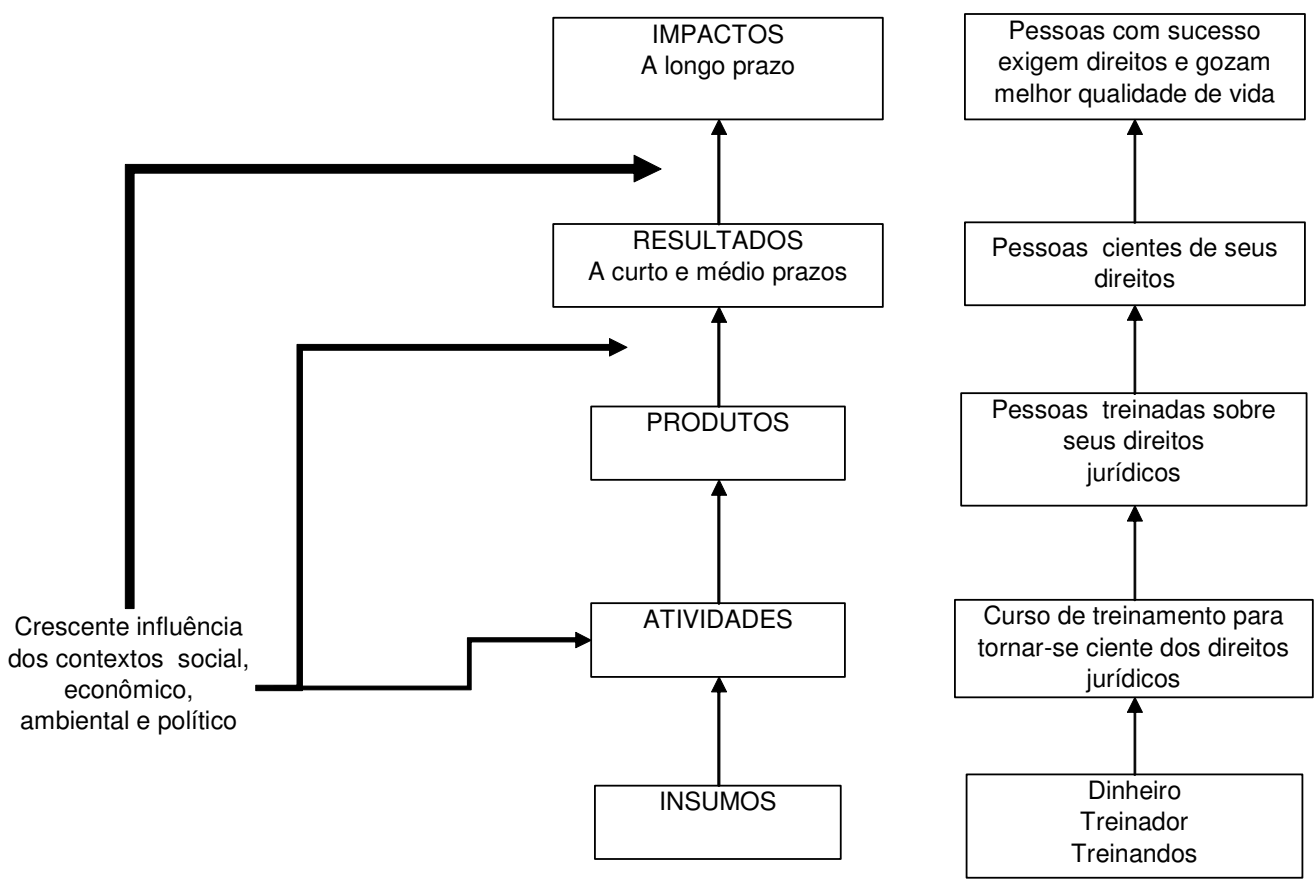

FIGURA 1.4 - Exemplo da cadeia de impacto na visão de Roche (2002)

Fonte : Adaptada das Figuras 2.2 e 2.5 de Roche (2002)

Um ponto comum nos trabalhos de Fitzsimmons e Fitzsimmons (2000); Gadrey (2001) e Roche (2002) é a concordância de que alguns processos de serviços não apresentam apenas o produto direto na sua saída (também denominado de output), existem ainda efeitos diretos a médio ou longo prazo desses produtos (também denominados de "impactos ou resultados ulteriores"). Portanto, diferentemente da perspectiva convencional de processos de manufatura, na prestação de alguns serviços há efeitos ou impactos que são importantes e almejados por esses prestadores. Vários exemplos desses efeitos ou impactos bem como de empresas ou entidades que os buscam - são listadas a seguir:

- aprovação em concursos (cursos preparatórios); 
- aumento da cidadania (Organizações Não-Governamentais (ONGs));

- aumento da sensação de segurança (firmas de segurança patrimonial, Polícia Militar);

- diminuição da mortalidade infantil (serviços sociais);

- geração de renda (ONGs);

- inclusão no mundo do trabalho (serviços sociais);

- melhoria da auto-estima (serviços sociais);

- melhoria da condição física (academias de ginástica);

- melhoria da qualidade de vida (serviços sociais);

- mudança de comportamento (Vigilantes do Peso, Alcoólicos Anônimos $(A A))$.

De maneira exploratória, os diferentes serviços podem ser classificados em três tipos, como ilustra a Figura 1.5, em relação à predominância de produtos diretos ou seus resultados ulteriores nas saídas do processo.

\begin{tabular}{|c|c|c|c|c|c|}
\hline \multirow{2}{*}{$\begin{array}{l}\text { Saídas do processo } \\
\text { buscadas pelos serviços } \\
\text { Tipos de Serviços }\end{array}$} & \multicolumn{5}{|c|}{ Produto direto do processo } \\
\hline & \multicolumn{5}{|c|}{ Exemplos de Serviços } \\
\hline $\begin{array}{l}\text { Atos físicos nas próprias } \\
\text { pessoas }\end{array}$ & $\begin{array}{l}\text { Transporte } \\
\text { aéreo }\end{array}$ & $\begin{array}{l}\text { Salão de } \\
\text { beleza }\end{array}$ & $\begin{array}{l}\text { Cirurgia } \\
\text { plástica }\end{array}$ & $\begin{array}{l}\text { Atividades } \\
\text { esportivas, } \\
\text { spa }\end{array}$ & $\begin{array}{l}\text { Fisioterapia } \\
\text { de } \\
\text { reabilitação }\end{array}$ \\
\hline $\begin{array}{l}\text { Atos físicos nas posses } \\
\text { (objetos físicos) das pessoas }\end{array}$ & Lavanderia & & $\begin{array}{c}\text { Serviços } \\
\text { compartilhados } \\
\text { de manutenção }\end{array}$ & $\begin{array}{r}\text { Proje } \\
\text { desenv }\end{array}$ & $\begin{array}{l}\text { os de } \\
\text { vimento }\end{array}$ \\
\hline $\begin{array}{l}\text { Atos não-físicos nas mentes } \\
\text { das pessoas }\end{array}$ & Jornais & Teatro & Escolas & $\begin{array}{l}\text { Igreja, } A A, \\
\text { Vigilantes do } \\
\text { peso }\end{array}$ & $\begin{array}{l}\text { Programas } \\
\text { sociais }\end{array}$ \\
\hline
\end{tabular}

FIGURA 1.5 - Os diferentes tipos de serviços segundo a natureza das saídas buscadas

Fonte: Baseada na classificação dos tipos de serviços proposta por Lovelock e Gummesson (2004) 
O confronto das visões dos diferentes autores indicou que não existe um consenso para definir o que vem a ser a saída de um processo de serviço. Revelou ainda a existência de serviços que objetivam primordialmente atingir os resultados indiretos de seus processos (efeitos dos seus produtos diretos ou imediatos). Dada a inexistência de uma denominação específica para esse tipo de serviços, o presente estudo propõe denominá-los de "Serviços de Resultados Ulteriores" (SRU).

O Quadro 1.3 expõe os outros componentes que compõem o processo de um SRU.

\begin{tabular}{|l|l|}
\hline Termo & Significado \\
\hline Resultados ulteriores & $\begin{array}{l}\text { Mudanças duradouras ou significativas, positivas ou negativas, planejadas ou não } \\
\text { nas vidas das pessoas ou nos resultados das empresas/entidades ocasionadas } \\
\text { pelos efeitos dos produtos diretos dos processos de transformação de serviços. }\end{array}$ \\
\hline Produto direto & $\begin{array}{l}\text { Resultado imediato de um processo de transformação. } \\
\text { Exemplos: Escola - aulas ministradas; Clínica de fisioterapia - atividades } \\
\text { terapêuticas; Igreja - missas/cultos celebrados. }\end{array}$ \\
\hline Processo de transformação & $\begin{array}{l}\text { Processos produtivos que utilizam recursos transformados e recursos de } \\
\text { transformação para mudar o estado ou a condição de algo produzindo produtos } \\
\text { diretos. Podem ser classificados em três tipos: } \\
\text { 1) Serviços que processam as próprias pessoas e que envolvem cada cliente } \\
\text { diretamente na entrega dos serviços; } \\
\text { 2) Serviços que processam as posses (objetos físicos) das pessoas; } \\
\text { 3) Serviços baseados na informação, cujos objetos transformados são as mentes } \\
\text { das pessoas ou seus ativos intangíveis (informação). }\end{array}$ \\
\hline Input & $\begin{array}{l}\text { Podem ser divididos em dois tipos: } \\
\text { Recursos transformados - aqueles que são tratados, transformados de alguma } \\
\text { forma. } \\
\text { Recursos de transformação - aqueles que agem sobre os recursos transformados } \\
\text { e são compostos de instalações, equipamentos, terreno, tecnologia do processo de } \\
\text { produça e funcionários que operam, mantêm, planejam e administram a produção. }\end{array}$ \\
\hline
\end{tabular}

QUADRO 1.3 - Termos e significados para serviços que objetivam primordialmente atingir os resultados indiretos de seus processos

Fonte: Baseado nos trabalhos de Fitzsimmons e Fitzsimmons (2000), Gadrey (2001), Roche (2002); Pfeiffer (2000 e 2005) e Slack et al. (2001). 


\subsubsection{Pontos sobre SRU que merecem ser melhor explorados}

Grande parte da literatura de gerenciamento de operações de serviços está voltada para aqueles "tradicionais" que visam ao lucro, tais como bancos e demais instituições financeiras, hospitais, restaurantes e bares, hotéis, seguradoras, empresas de notícias e entretenimento, transportadoras de carga e de passageiros, empresas de atacado e varejo e serviços profissionais. Esta tendência pode ser verificada por uma análise dos principais livros didáticos de gerenciamento de operações de serviços, como Corrêa e Caon (2002); Fitzsimmons e Fitzsimmons (2005); Haksever et al. (2000); Johnston e Clark (2002); Lovelock e Wright (2002); Normann (1993) e Schmenner (1999). Partindo-se dessa constatação, levanta-se um ponto que merece uma investigação mais apurada: SRUs são pouco explorados na literatura de gerenciamento de operações de serviços.

Vários tipos de serviços podem ser enquadrados na categoria de SRU. Visando delimitar o campo de pesquisa desta tese, não serão analisados todos os tipos de SRU. A análise restringir-se-á aos serviços que "processam pessoas". Este recorte é necessário devido às características específicas desta categoria em relação a outros tipos de SRU. Algumas destas características serão listadas neste capítulo, para que o leitor possa melhor compreender o tema da tese e sua importância.

Bitner et al. (1997) discutem o papel dos clientes nos serviços. Eles apontam que o grau de participação do cliente no serviço pode ser visto em três níveis (baixo, moderado e alto), conforme detalhado no Quadro 1.4.

Ainda de acordo com Bitner et al. (1997), os clientes podem desempenhar três diferentes papéis e, em alguns serviços, podem desempenhar um ou mais deles como dados a seguir

i) cliente como recurso produtivo: assumindo a execução de parte do processo de serviço, exercendo uma importante função para a melhoria da produtividade nas empresas; 
ii) cliente como contribuinte para qualidade, satisfação e valor: pode contribuir para sua própria satisfação e, conseqüentemente, para a qualidade dos serviços adquiridos. A sua efetiva participação aumenta a probabilidade de se atingirem os benefícios por eles almejados sendo particularmente crítica para serviços como educação, programas de saúde e outros em que os resultados são altamente dependentes da participação do cliente. Nesses casos, ele é parte integral do serviço e, se não cumprir seu papel eficazmente, o resultado desejado não pode ser alcançado. O mesmo ocorre no caso de um cliente organizacional que recorre aos serviços de gerenciamento de um consultor: a não ser que a organização acate as recomendações do consultor, os benefícios da consultoria não poderão ser verificados;

iii) cliente como competidor para o servico: um papel que também pode ser protagonizado pelos clientes é de competidor potencial. Em muitas situações (indivíduos ou companhias), têm a escolha de comprar serviços na esfera comercial ou eles próprios produzirem o serviço - completamente ou de maneira parcial. Portanto, de certo modo, podem ser competidores das companhias que fornecem o serviço.

\begin{tabular}{|c|c|c|}
\hline $\begin{array}{l}\text { Baixo: presença do cliente } \\
\text { requerida durante a entrega do } \\
\text { serviço }\end{array}$ & $\begin{array}{l}\text { Moderado: inputs do cliente são } \\
\text { exigidos para a execução do serviço }\end{array}$ & $\begin{array}{l}\text { Alto: O cliente "co-cria" o produto do } \\
\text { serviço }\end{array}$ \\
\hline Os produtos são padronizados. & $\begin{array}{l}\text { Os inputs do cliente customizam um } \\
\text { serviço normal. }\end{array}$ & $\begin{array}{l}\text { Ativa participação do cliente que conduz } \\
\text { à personalização do serviço. }\end{array}$ \\
\hline $\begin{array}{l}\text { O serviço é oferecido sem considerar } \\
\text { qualquer compra individual. }\end{array}$ & $\begin{array}{l}\text { A execução do serviço depende da } \\
\text { compra pelo cliente. }\end{array}$ & $\begin{array}{l}\text { O serviço não pode ser criado sem que } \\
\text { o cliente faça a compra e participe } \\
\text { ativamente. }\end{array}$ \\
\hline $\begin{array}{l}\text { O pagamento pode ser a única } \\
\text { participação do cliente. }\end{array}$ & $\begin{array}{l}\text { Os inputs do cliente (materiais e/ou } \\
\text { informações) são necessários para o } \\
\text { resultado adequado, mas é a empresa } \\
\text { que executa o serviço. }\end{array}$ & $\begin{array}{l}\text { Os inputs do cliente são obrigatórios e } \\
\text { "co-criam" o resultado. }\end{array}$ \\
\hline Exemplos: & Exemplos: & Exemplos: \\
\hline $\begin{array}{l}\text { Consumidor final: } \\
\text { Viagem área }\end{array}$ & $\begin{array}{l}\text { Consumidor final: } \\
\text { Corte de cabelo }\end{array}$ & $\begin{array}{l}\text { Consumidor final: } \\
\text { Alcoólicos Anônimos (AA) }\end{array}$ \\
\hline $\begin{array}{l}\text { B2B: } \\
\text { Serviço de manutenção }\end{array}$ & $\begin{array}{l}\text { B2B: } \\
\text { Agência de publicidade criando uma } \\
\text { campanha }\end{array}$ & $\begin{array}{l}\text { B2B: } \\
\text { Consultoria em gestão }\end{array}$ \\
\hline
\end{tabular}

QUADRO 1.4 - Níveis de participação dos clientes em diferentes serviços

Fonte: Bitner et al. (1997). 
Com base no framework proposto por Bitner et al. (1997) para os SRUs, podem-se tecer as seguintes considerações:

- o nível de participação do cliente varia de moderado a alto;

- os clientes atuam como contribuintes para qualidade, satisfação e valor.

Logo, os efetivos empenho e participação dos clientes tornam-se elementos importantes para se atingir os benefícios buscados pelo serviço.

Considerando o exposto, pode-se levantar um novo ponto que merece ser melhor explorado: Nos SRUs que processam pessoas, os resultados ulteriores buscados pelo serviço dependem de os clientes participarem e se empenharem em atividades que fazem parte do processo de entrega do serviço.

Além dessas, as seguintes características observadas nestes serviços podem ser acrescentadas:

- os resultados ulteriores vão se manifestando ao longo do tempo, até que o resultado ulterior final seja alcançado. Por exemplo: uma pessoa que freqüenta uma academia de ginástica pode ter como objetivo (resultado ulterior final) o seu emagrecimento. Este resultado só será obtido de modo paulatino ${ }^{4}$ (ROSEN, 1993);

- os resultados ulteriores dependem da freqüência e da maneira como o cliente obtem os produtos diretos do serviço. Por exemplo: 0 emagrecimento almejado pelo cliente, ao freqüentar uma academia de ginástica, depende, em grande parte, do cumprimento das atividades físicas previstas em sua ficha diária de treinamento. O resultado será obtido pelo efeito cumulativo dessas atividades ao longo do tempo. A Figura 1.6 esclarece esse mecanismo.

\footnotetext{
${ }^{4}$ Em uma reportagem de jornal, Araújo (2006) relatou o tempo médio que várias modalidades de ginástica demandam para apresentarem os primeiros resultados efetivos. Para ioga, pilates, alongamento, power jump, spinning, body combat e dança, os resultados aparecem em cerca de um mês. Já em atividades como power pool e hidroginástica, os resultados aparecem em cerca de 2 ou 3 meses.
} 


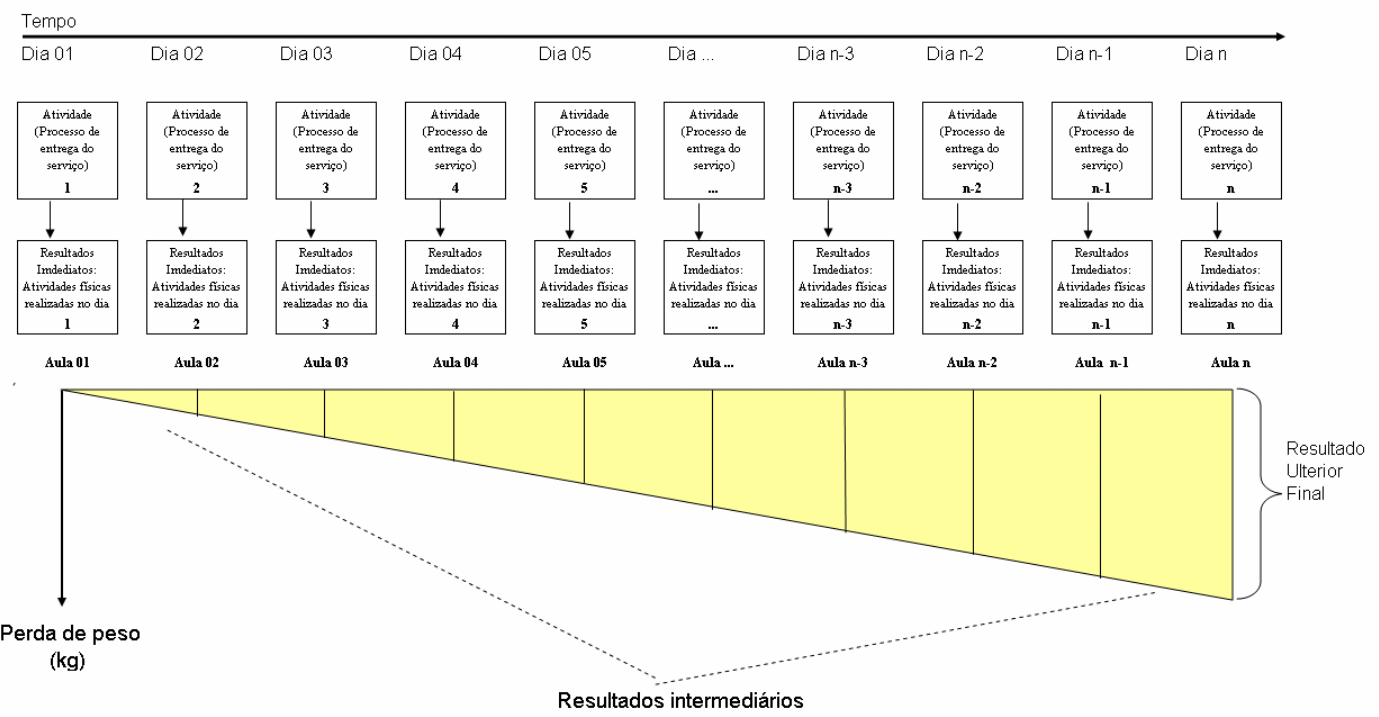

FIGURA 1.6- Dinâmica de surgimento dos resultados ulteriores Fonte: Pesquisa do autor (2007)

Ao contrário do que ocorre em muitos tipos de serviços, os SRUs não se finalizam com um único episódio ou encontro de serviço. Dependem de vários deles para que os resultados almejados sejam alcançados. Isso, de certo modo, evidencia a necessidade do estabelecimento de um relacionamento entre o provedor de serviço e o cliente, devido à interdependência entre os diferentes encontros e, por conseqüência, a necessidade de sua continuidade. Esse relacionamento deve ser monitorado e controlado de tal modo que se possa identificar e realizar os ajustes necessários, caso os resultados ulteriores intermediários estejam aquém do buscado e, assim, o objetivo possa ser finalmente alcançado.

As considerações discorridas sobre os SRUs que processam pessoas remetem a outro ponto que carece de mais investigação: para que os resultados ulteriores sejam alcançados, o provedor de serviços deve estabelecer um sistema de monitoramento e controle que indique e realize os ajustes e correções necessários em seu processo de entrega.

Vários trabalhos - Edvardsson et al. (2000), Gustafsson e Johnson (2003), Oliva e Kallenberg (2003), Téboul (1999) - têm enfatizado a importância das empresas, sejam prestadoras de serviços ou manufatureiras, desenvolverem 
inovações para reforçar sua competitividade e assim, sobreviver no mercado. Neste contexto, Haksever et al. (2000) listam vários fatores que têm levado as companhias a desenvolverem mais serviços:

- as necessidades dos clientes têm mudado rapidamente e novas necessidades têm surgido;

- diante do surgimento de novas preferências e estilos de vida, muitos serviços tornam-se obsoletos ou inadequados para atender a essas novas expectativas;

- as organizações vêm sendo pressionadas a atingir metas de aumento de lucro, participação de mercado e receitas que só podem ser alcançadas com a introdução de novos serviços no mercado;

- introdução de novos serviços pela concorrência;

- aumento da globalização, com a conseqüente internacionalização de vários serviços;

- a criação de novas necessidades motivadas e impulsionadas pelos avanços tecnológicos, por intermédio de: i) novos produtos que demandam itens associados, como manutenção, treinamento etc; ii) novos equipamentos que possibilitam a melhoria dos processos existentes ou mesmo a criação de outros; iii) avanços nos formatos de networking eletrônico, como a Internet, bancos de dados eletrônicos, telefonia celular, etc, que tornam possível a criação e entrega de novos serviços;

- desregulamentação de alguns setores, possibilitando sua abertura a novas empresas;

- regulamentação de alguns setores ou serviços, impondo novas regras e práticas;

- eliminação de algumas restrições de entidades profissionais que favorecem o desenvolvimento e a entrega de novos serviços;

- crescimento das franquias que possibilitam aos franqueadores focalizarem suas atividades no desenvolvimento de novos serviços; 
- oferta de novos serviços como estratégia para utilizar a capacidade ociosa.

Apesar da tendência de crescimento e da sua importância, o desenvolvimento de serviços permanece como um tema pouco estudado na literatura de gerenciamento de serviços. Portanto, reconhece-se que várias perguntas podem ser levantadas quando se discute este assunto: Quais são os diferentes tipos de serviços existentes? O que constitui novos serviços e como eles se diferem? Quais são as fases, as atividades e as características do processo de desenvolvimento de serviços bem-sucedidos? Quais são as melhores práticas de desenvolvimento? Quais são os fatores que levam o desenvolvimento de serviços ao sucesso? Quais métodos/técnicas devem ser utilizados em cada uma das fases? Estas e várias outras perguntas poderiam ser formuladas pelo leitor ao tratar deste tema. A existência de tantas questões a serem elucidadas revela o baixo grau de desenvolvimento da literatura sobre o tema (MENOR et al., 2002; MELLO, 2005). Isto se torna mais evidente se compararmos a literatura referente ao desenvolvimento de serviços com a referente ao desenvolvimento de produtos. $\mathrm{Na}$ primeira poder-se-á encontrar um vasto número de trabalhos já publicados, o que ainda não ocorre com a segunda.

A respeito do desenvolvimento de serviços, Johne e Storey (1998) e Jong e Vermeulen (2003), que fizeram uma extensa revisão bibliográfica sobre este tema, sugerem que a grande maioria dos serviços estudados não se refere à categoria tratada neste trabalho que busca resultados ulteriores. Portanto, trabalhos que auxiliem o desenvolvimento desse campo de estudo são relevantes para ampliar os conhecimentos voltados à concepção, implantação e operação de sistemas de serviços.

Dessa maneira, estudos que elucidam as características de um processo adequado de entrega de SRU podem impulsionar a pesquisa nessa área, sobretudo, no que se refere a sistematização de seu planejamento.

Levando-se, pois, em conta o exposto, identificou-se mais um ponto que merece ser considerado: o baixo entendimento atualmente existente sobre 0 processo de desenvolvimento de SRU impõe a necessidade de compreender quais 
características são desejáveis para o processo de entrega desses serviços, como um meio de auxiliar sua etapa de desenvolvimento.

\subsection{PROBLEMA DA PESQUISA}

A partir da conjuntura apresentada, nota-se uma premente necessidade de compreender como a adoção de um sistema de monitoramento e controle e a utilização de táticas que estimulem o envolvimento e a participação dos clientes contribuem para um melhor desempenho num SRU. A Figura 1.7 ilustra a situaçãoproblema que motiva o desenvolvimento do presente trabalho.

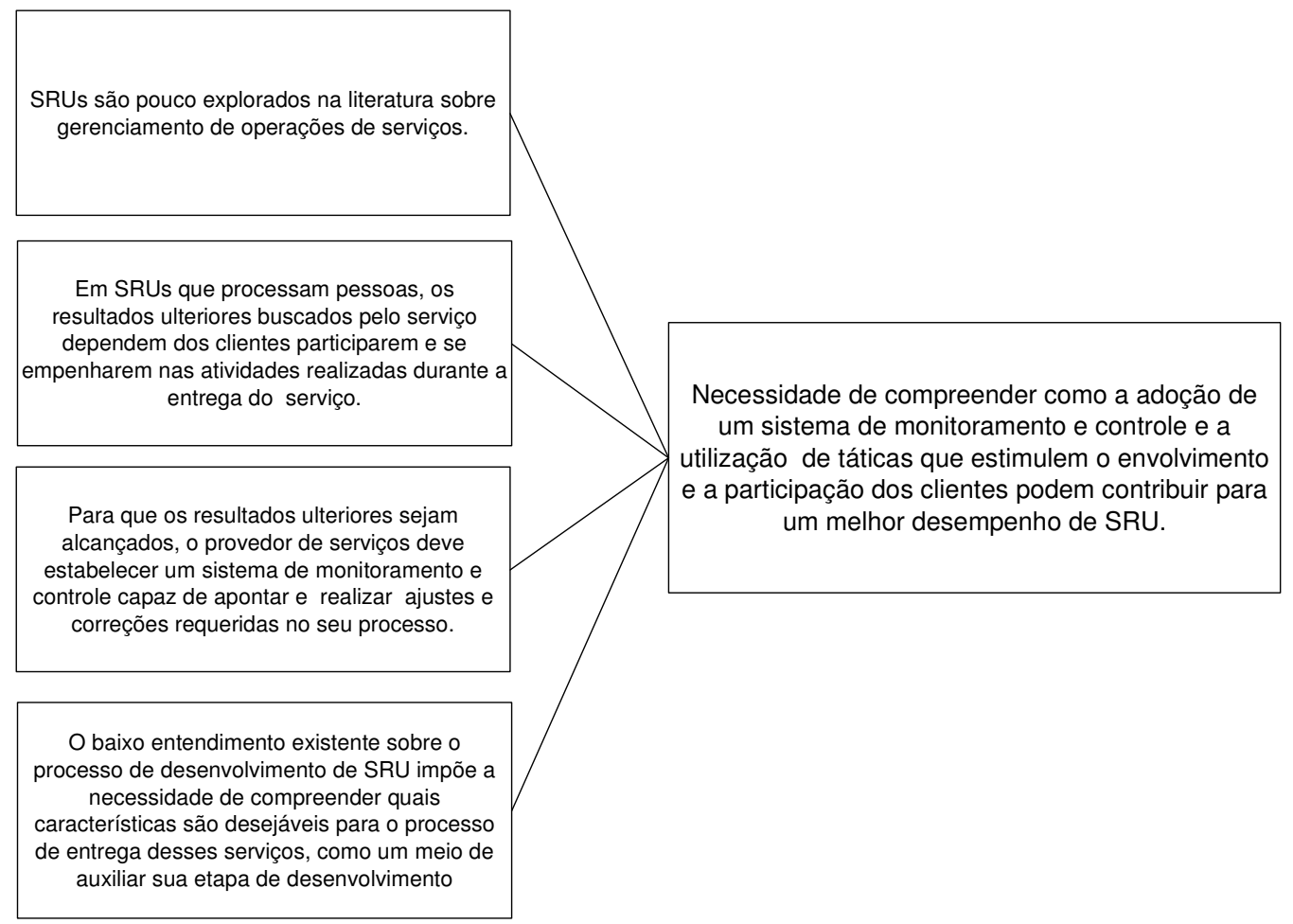

FIGURA 1.7 - Pontos que merecem ser melhor explorados

Fonte: Elaborada pelo Autor (2007) 
Essa compreensão é fundamental na medida em que possibilitará um esclarecimento das características desejáveis para o processo de entrega de SRUs e a definição de diretrizes para orientar o desenvolvimento destes serviços.

O Quadro 1.5 apresenta a estrutura que organiza este trabalho.

\begin{tabular}{|c|c|c|}
\hline Capítulo & Título & Objetivo \\
\hline 1 & Introdução & Proporcionar uma visão geral do trabalho. \\
\hline 2 & Objetivo & $\begin{array}{l}\text { Explicitar os objetivos geral e específico e delimitar qual é o objeto de } \\
\text { estudo da tese. }\end{array}$ \\
\hline 3 & Referencial teórico & $\begin{array}{l}\text { Desenvolver revisão bibliográfica sobre SRU. } \\
\text { Buscar na literatura conceitos e proposições que ajudem a definir as } \\
\text { características de um sistema de monitoramento e controle voltado } \\
\text { para o relacionamento com os clientes e delinear táticas que } \\
\text { favoreçam a maior participação e envolvimento dos clientes nas } \\
\text { atividades executadas por eles. } \\
\text { Discutir as diferentes dimensões de desempenho existentes em } \\
\text { serviços e buscar na literatura argumentações que ajudem a justificar } \\
\text { a escolha de algumas delas. }\end{array}$ \\
\hline 4 & Metodologia de pesquisa & Expor e justificar o método de pesquisa adotado no trabalho. \\
\hline 5 & Descrição dos casos & Apresentar relato dos estudos de caso conduzidos em SRUs. \\
\hline 6 & $\begin{array}{l}\text { Análise e discussão dos } \\
\text { resultados }\end{array}$ & $\begin{array}{l}\text { Apresentar análise e considerações a respeito dos casos e } \\
\text { respectivos dados. }\end{array}$ \\
\hline 7 & Conclusões & $\begin{array}{l}\text { Explicitar as principais conclusões alcançadas, levando-se em } \\
\text { consideração os objetivos do trabalho e as proposições formuladas. } \\
\text { Sugerir recomendações para futuras pesquisas. }\end{array}$ \\
\hline & Anexos & \\
\hline
\end{tabular}

QUADRO 1.5 - Estrutura da tese

Fonte: Elaborado pelo autor 


\section{OBJETIVO}

\subsection{O TEMA E SEU OBJETO DE ESTUDO}

Uma vez definido o problema que a tese pretende analisar, pode-se traçar o objetivo inicial desta pesquisa. A tese objetiva auxiliar as empresas de SRU que processam pessoas, discutindo e esclarecendo como a adoção de um sistema de monitoramento e controle e a utilização de táticas que estimulam o envolvimento e a participação dos seus clientes podem contribuir para que elas obtenham um melhor desempenho.

Todavia, tal objetivo é demasiadamente extenso para uma tese de doutorado. Em virtude disso, é preciso torná-lo mais específico. Dessa forma, esta seção apresenta as delimitações consideradas para a configuração do objeto do presente estudo.

Duas grandes delimitações foram realizadas: a primeira refere-se à natureza do serviço que será pesquisado; a segunda, ao grau de consolidação do serviço no mercado.

Com relação à primeira delimitação, foram assumidos três recortes em termos de volume de processamento, natureza do output e tipo de serviço:

a) volume de processamento: o trabalho não se propõe a contemplar os serviços considerados profissionais. Este recorte foi realizado na medida em que tais serviços caracterizam-se por um volume de processamento baixo e grande customização. Por outro lado, no entender de autores como Kellogg e Nie (1995), as empresas que se enquadram na categoria de lojas de serviços ou serviços de massa apresentam uma homogeneidade maior em seus pacotes de serviço, o que se torna mais relevante, nessas últimas, a busca de objetivos típicos de gerenciamento de operações, como eficiência, eficácia, produtividade e custo. Levando-se, pois, em conta a importância desses objetivos para os estudos desenvolvidos na área de 
Gestão de Operações da Engenharia de Produção, apenas empresas da categoria de lojas de serviços ou serviços de massa serão analisadas.

b) natureza do output: a revisão da literatura possibilitou identificar a existência de vários SRUs. Neste trabalho, serão contemplados somente os SRUs que processam pessoas.

c) tipo de serviço: utilizando-se a tipologia proposta por Lovelock e Yip (1996), o trabalho irá focalizar os serviços que processam as próprias pessoas ("atos físicos nas próprias pessoas") e os serviços baseados na informação, cujos objetos transformados são as mentes das pessoas (atos não-físicos nas mentes). Em ambos tipos de serviços, os clientes desempenham também o papel de produto do processo, se considerarmos a classificação proposta por Lengnick-Hall (1996) ${ }^{5}$.

Como apontado anteriormente, a segunda delimitação refere-se ao grau de consolidação do serviço no mercado. Pode-se dizer que, de modo geral, esta delimitação refere-se diretamente ao grau de adequação do serviço fornecido pela empresa perante o mercado. Quanto maior o seu tempo de existência, maior é a probabilidade de que o serviço se ajustou às necessidades dos seus clientes, e já é capaz de atuar em condições adequadas de operação. Além disso, serviços lançados recentemente no mercado correm o risco de não possibilitarem a verificação da eficácia dos seus resultados ulteriores almejados. Assim sendo, o trabalho se restringe a analisar serviços em operação, já existentes há alguns anos no mercado.

A Figura 2.1 sintetiza as duas grandes delimitações realizadas, com seus respectivos recortes, para definir o objeto de trabalho.

O desempenho de um serviço pode ser decomposto em vários critérios, que podem ser mensuradas de diferentes maneiras. Três critérios foram escolhidos neste trabalho como relevantes para a determinação do desempenho do serviço. São elas:

- eficácia: pode ser definida pela relação entre resultados obtidos e previstos (SINK e TUTTLE, 1993). Mede o grau de atingimento dos resultados ulteriores que foram almejados;

\footnotetext{
${ }^{5}$ Os papéis que o cliente desempenha nos serviços discutidos neste trabalho serão detalhados na seção 3.3.
} 
- taxa de retenção de clientes: está relacionada com a capacidade de uma empresa satisfazer o cliente e assim retê-lo;

- freqüência: está diretamente relacionada à adesão e à participação do cliente nas atividades que fazem parte do processo de entrega do serviço. Tanto a freqüência quanto a taxa de retenção de clientes são extremamente relevantes, na medida em que dependem do envolvimento e da participação do cliente no processo de entrega do serviço.

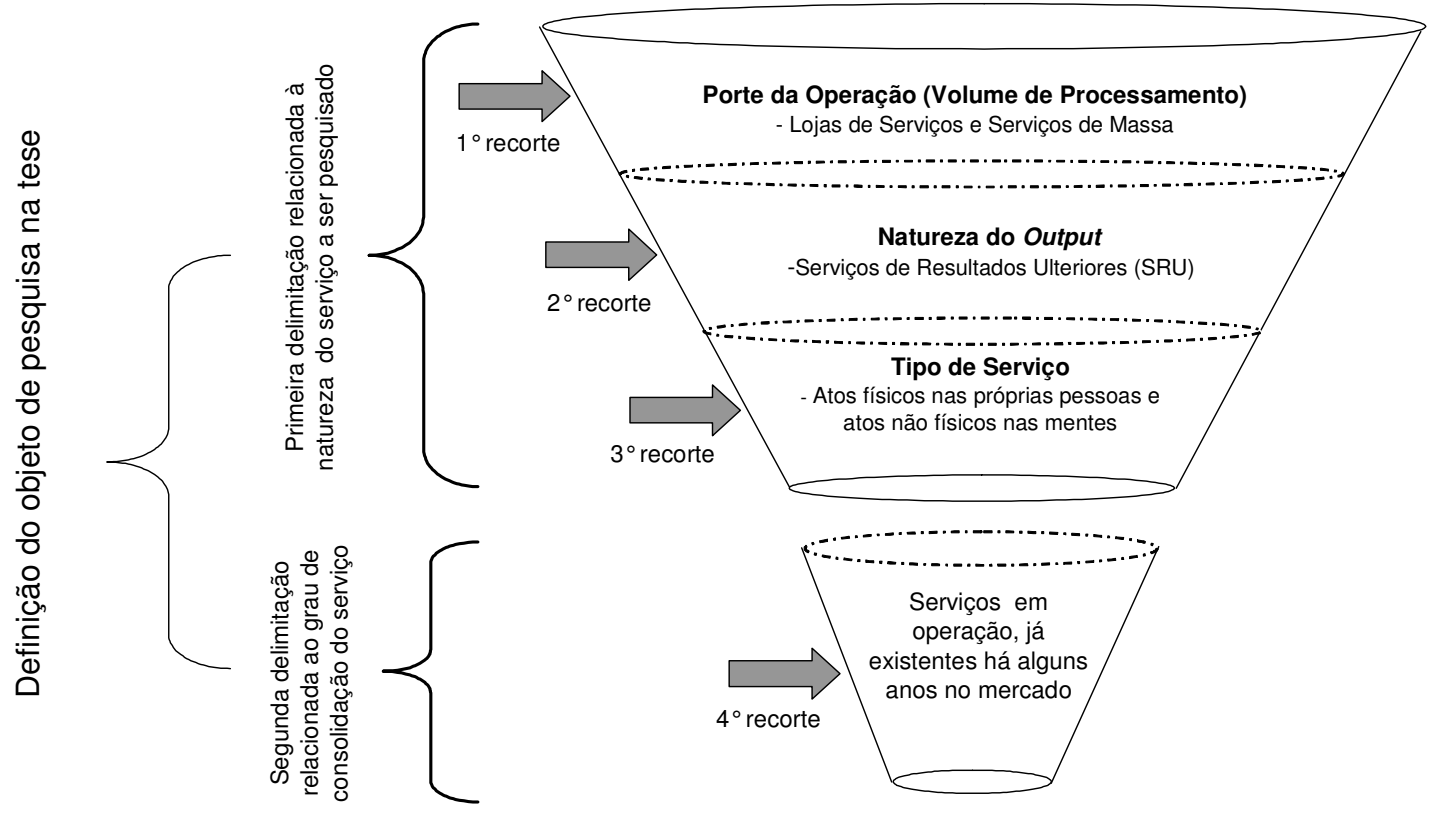

FIGURA 2.1 - Delimitações realizadas e seus respectivos recortes

Fonte: Pesquisa do autor (2007).

A revisão bibliográfica realizada e uma pesquisa de campo preliminar evidenciaram que esses serviços necessitam de um sistema de monitoramento e controle voltado para o relacionamento com os clientes no processo de entrega do serviço. Do mesmo modo, indicaram a importância da promoção um conjunto de táticas que estimulam o envolvimento e a participação dos clientes. ${ }^{6}$

\footnotetext{
${ }^{6}$ As características do sistema de monitoramento e as táticas que estimulam o envolvimento e a participação dos clientes são descritas na seção 3.5 .
} 


\subsection{OBJETIVO GERAL DA TESE}

Face às delimitações e considerações expostas anteriormente, pode-se definir, de modo mais preciso, o objetivo desta tese como segue: gerar novos conhecimentos para o desenvolvimento da gestão de operações em empresas de SRU que processam pessoas, classificadas como loja de serviços ou serviços de massa. Para tanto, o presente trabalho se propõe a discutir e elucidar como um sistema de monitoramento e controle voltado para o relacionamento com os clientes, e como a adoção de táticas que estimulam o envolvimento e a participação do seu público, podem contribuir para que as empresas de SRU obtenham níveis satisfatórios de eficácia e retenção da clientela.

\subsection{OBJETIVOS ESPECÍFICOS}

A partir do objetivo geral, são estabelecidos a seguir os objetivos específicos que nortearão o desenvolvimento do trabalho:

I - ao verificar as implicações de pesquisa no campo, o trabalho visa identificar quais meios (estrutura organizacional, práticas, ferramentas, metodologias, recursos tecnológicos) são adotados pelas organizações para 0 monitoramento do serviço;

II - o trabalho visa ainda contribuir para a adequada implementação de SRUs, na medida em que identifica diretrizes gerenciais para a realização das atividades operacionais destes serviços. Por conseguinte, essas diretrizes podem ser consideradas pelos gestores como uma referência para a tomada de ações que visem ao melhoramento daquelas atividades;

III - também visa contribuir para um melhor entendimento de como objetivos operacionais conflitantes como eficiência e eficácia podem ser administrados em SRU; 
IV - a busca do objetivo geral deste trabalho requer o desenvolvimento de métodos para avaliar o grau de aplicação de um sistema de monitoramento e controle e o grau de adoção de táticas que estimulam o envolvimento e a participação dos clientes. A elaboração destes métodos pode contribuir para uma melhor análise e avaliação de SRUs.

\subsection{QUESTÕES DE PESQUISA E PROPOSIÇÕES A SEREM VERIFICADAS}

A partir do objetivo geral proposto, três questões de pesquisa mais específicas são desdobradas para direcionar o desenvolvimento da pesquisa. $A$ primeira questão é: a implementação de um sistema de monitoramento e controle voltado para o relacionamento com seus clientes possibilita que as empresas de $\mathrm{SRU}$, que processam pessoas, obtenham níveis satisfatórios de eficácia? A segunda questão é: a adoção de táticas que favorecem maior participação e envolvimento dos clientes nas atividades executadas possibilita que as empresas de SRU, que processam pessoas, obtenham níveis satisfatórios de eficácia? Finalmente, a terceira questão a ser respondida pela tese é: em empresas de SRU que processam pessoas, a capacidade do sistema de monitoramento existente em realizar ajustes e correções no processo de entrega do serviço influencia positivamente a retenção de clientes?

O desdobramento destas três questões a serem investigadas pelo trabalho implica na formulação de três proposições de pesquisa, as quais são definidas a seguir:

- Primeira Proposição $\left(P_{1}\right)$ : A obtenção de níveis satisfatórios de eficácia em empresas de SRU que processam pessoas é suportada pela implementação de um sistema de monitoramento e controle voltado para o relacionamento da organização com seu público.

- Segunda Proposição $\left(P_{2}\right)$ : A obtenção de níveis satisfatórios de eficácia em empresas de SRU que processam pessoas é suportada pela adoção 
de táticas que favoreçam maior participação e envolvimento dos clientes nas atividades.

- Terceira Proposição $\left(P_{3}\right)$ : A retenção de clientes em empresas de SRU que processam pessoas é influenciada pela capacidade do sistema de monitoramento existente em realizar ajustes e correções em seu processo de entrega do serviço. 


\section{REFERENCIAL TEÓRICO}

Este capítulo analisa vários assuntos relacionados aos objetivos propostos, a partir de uma revisão da literatura.

Inicialmente, procura-se entender e definir o que é um serviço, mas a bibliografia consultada mostra que não é possível estabelecer uma única definição, na medida em que as principais características diferenciadoras dos serviços como intangibilidade, variabilidade, simultaneidade e não-estocabilidade nem sempre podem ser observadas em alguns serviços. Posteriormente, várias classificações são apresentadas. Constatou-se que nenhuma delas identifica de modo genérico os SRUs. Em seguida, as principais características dos SRUs são retratadas à luz dos diferentes papéis que o cliente realiza durante o processo de entrega. Faz-se uma breve discussão sobre a medição de desempenho em serviço. Apresentam-se o conceito de trade-off e alguns modelos de medição de desempenho. Finalmente, considerando o referencial teórico e o objetivo da tese, é definida a estrutura conceitual que será utilizada na pesquisa.

\subsection{CONCEITUALIZANDO SERVIÇOS}

Apesar da existência de vários trabalhos sobre serviços, ainda não existe um consenso sobre sua definição. Na acepção de Grönroos (2003, p. 65), o serviço pode ser entendido como:

[...] "um processo, consistindo em uma série de atividades mais ou menos intangíveis que, normalmente, mas não necessariamente sempre, ocorrem nas interações entre o cliente e os funcionários de serviço e/ou [entre o cliente e os] recursos ou bens físicos e/ou [entre o cliente e os] sistemas do fornecedor de serviços e que são fornecidas como soluções para problemas do cliente".

Este autor ainda salienta que várias definições de serviços podem ser levantadas e, muitas delas, incluem somente aqueles prestados pelas chamadas "empresas de serviços". 
Gadrey (2000), em face da diversidade de conceitos sobre serviços, se propôs a elaborar uma única definição diferenciadora, capaz de abranger todos os tipos de serviços existentes. Apesar de ter construído uma proposta de definição, ele reconhece que não foi possível cumprir seus objetivos iniciais.

Em um trabalho relativamente recente, Edvardsson; Gustafsson e Roos (2005) coletaram as visões de 11 especialistas em serviços sobre a definição que julgavam melhor capturar o que se pode considerar como a essência dos serviços. No Quadro 3.1, as distintas respostas que foram obtidas são enumeradas.

Uma breve análise do Quadro 3.1 confirma a visão de Grönroos (2004) de que inexiste um consenso sobre o que é serviço. Observa-se também que as definições estão em um nível abstrato e podem ser operacionalizadas e interpretadas de modos diferentes. Acredita-se que elas se situam neste nível para que possam lidar com a diversidade que caracteriza os variados tipos de serviço.

Edvardsson; Gustafsson e Roos (2005) separam estas definições em dois grupos: o primeiro grupo aborda os serviços como atividades que são objeto de troca, enquanto no segundo grupo o serviço é colocado sob a perspectiva de criação de valor. 


\begin{tabular}{|c|c|}
\hline $\begin{array}{l}\text { Especialista de } \\
\text { serviço }\end{array}$ & Resposta dada \\
\hline Especialista 1 & $\begin{array}{l}\text { "Serviço" significa itens diversos em diferentes contextos. Na perspectiva do cliente, o "serviço" é } \\
\text { a combinação da experiência do cliente e sua percepção sobre o resultado obtido. }\end{array}$ \\
\hline Especialista 2 & $\begin{array}{l}\text { Eu não penso que achando uma definição de uma ou duas linhas faça sentido. No meu modo de } \\
\text { ver: "Bens são coisas, serviços são atividades. Bens desempenham serviços e serviços } \\
\text { desempenham serviços". }\end{array}$ \\
\hline Especialista 3 & $\begin{array}{l}\text { Em minha opinião qualquer definição do que é serviço será problemática. "Um serviço é um } \\
\text { processo queconsiste de uma série de atividades mais ou menos tangíveis que normalmente, mas } \\
\text { não necessariamente sempre, ocorrem através de interações entre o cliente e o empregado do } \\
\text { serviço e/ou os recursos físicos, ou bens e/ou sistemas do fornecedor de serviço, no qual são } \\
\text { fornecidos como soluções para os clientes". } \\
\text { Num contexto comercial, minha definição talvez seja: "Serviço é suporte ao processo de alguém, } \\
\text { então um dado valor é criado nesse processo para esta pessoa (organização)". Ista é a definição de } \\
\text { serviço na perspectiva que penso que devia ser vista, considerando que a primeira definição é uma } \\
\text { definição de serviço como uma atividade. Na literatura, os serviços são sempre definidos como } \\
\text { uma atividade. }\end{array}$ \\
\hline Especialista 4 & $\begin{array}{l}\text { Deveríamos discutir serviço em vez de serviços. O termo "serviços" é muito limitante porque } \\
\text { implica em sua dimensão de setor. Atualmente, o serviço está encampando tudo, e os bens físicos } \\
\text { são apenas partes dele. Minha definição de serviço poderia ser "satisfação das necessidades e } \\
\text { desejos do cliente." }\end{array}$ \\
\hline Especialista 5 & $\begin{array}{l}\text { Eu gosto da definição anterior dada por Rathmell (1966) : "Um serviço é uma ação, um ato, um } \\
\text { esforço". Eu nunca apreciei debates acerca das melhores maneiras de se definir alguma coisa. }\end{array}$ \\
\hline Especialista 6 & $\begin{array}{l}\text { Os serviços são atividades econômicas oferecidas por uma parte à outra, comumente empregando } \\
\text { um tempo definido para obter os resultados desejados pelos próprios receptores do serviço ou em } \\
\text { objetos ou outros recursos nos quais os compradores do serviço têm responsabilidade. Os clientes } \\
\text { de serviço esperam obter valor do acesso ao trabalho, habilidades profissionais, instalações, redes, } \\
\text { sistemas, e equipamentos oferecidos, mas usualmente não tomam propriedade de quaisquer dos } \\
\text { elementos físicos envolvidos. }\end{array}$ \\
\hline Especialista 7 & $\begin{array}{l}\text { Ações, processos e atos. Isto foi atribuído por muitos autores, então eu não estou certo de onde } \\
\text { vem. É simples e inclui todos os serviços. }\end{array}$ \\
\hline Especialista 8 & $\begin{array}{l}\text { A essência de serviço é a experiência criada aos clientes quando estes travam contato com uma } \\
\text { empresa provedora, um time, e/ou um indivíduo. A experiência tem dois componentes } \\
\text { importantes: a qualidade central (comida, roupa) e a qualidade da entrega. }\end{array}$ \\
\hline Especialista 9 & $\begin{array}{l}\text { Eu definiria serviços como "processos, atos e ações que refletem e resultam da transformação de } \\
\text { recursos da empresa (diferente de produtos físicos) em valor-adicionado ou benefícios para os } \\
\text { clientes externos e internos da empresa". A origem desta definição é Vargo e Lusch (2004, p.2) } \\
\text { que definem serviços como "a aplicação de competências especializadas (conhecimento e } \\
\text { habilidades) através de ações, processos, e atos para o benefício de outra entidade ou à própria } \\
\text { entidade". }\end{array}$ \\
\hline Especialista 10 & $\begin{array}{l}\text { Um serviço, em essência, é um ato significativo que fornece um benefício. Pode ser executado para } \\
\text { um cliente ou por um cliente. Diferentemente do que ocorre com bens, serviços são usados, mas } \\
\text { não possuídos pelo cliente. }\end{array}$ \\
\hline Especialista 11 & $\begin{array}{l}\text { "Os serviços são ações, processos e atos" (ver Zeithaml e Bitner, 2003). Eu gosto desta definição } \\
\text { porque é ampla e engloba organizações sem fins lucrativos e industriais. }\end{array}$ \\
\hline
\end{tabular}

QUADRO 3.1 - As diferentes definições de serviço

Fonte : Tabela II de Edvardsson; Gustafsson e Roos (2005) 
Uma outra maneira de compreender o que vem a ser um serviço é analisar as características que o diferenciam de um bem tangível.

Com o propósito de responder quais seriam as características diferenciadoras das organizações de serviços, Normann (1993) analisou comparativamente as indústrias de manufatura e serviço. Esta análise é apresentada pelo Quadro 3.2.

\begin{tabular}{|l|l|}
\hline Indústrias Manufatureiras & Indústrias de Serviços \\
\hline Geralmente o produto é concreto. & O serviço é intangível. \\
\hline A posse é transferida quando uma compra é efetuada. & Geralmente a posse não é transferida. \\
\hline O produto pode ser revendido. & O produto não pode ser revendido. \\
\hline O produto pode ser demonstrado. & O produto não pode ser demonstrado com eficácia. \\
\hline $\begin{array}{l}\text { O produto pode ser estocado por vendedores e } \\
\text { compradores. }\end{array}$ & O serviço não pode ser estocado. \\
\hline O consumo depende da produção. & Produção e consumo geralmente coincidem. \\
\hline $\begin{array}{l}\text { Produção, venda e consumo são feitos em locais } \\
\text { diferentes. }\end{array}$ & $\begin{array}{l}\text { Produção, consumo e, frequentemente, a venda são } \\
\text { feitos no mesmo local. }\end{array}$ \\
\hline A produção é realizada pelo fabricante. & $\begin{array}{l}\text { O comprador/cliente participa diretamente da } \\
\text { produção. }\end{array}$ \\
\hline É possível contato indireto entre o fabricante e cliente. & \begin{tabular}{l} 
Na maioria dos casos, o contato direto é necessário. \\
\hline O produto pode ser exportado.
\end{tabular} \\
\hline
\end{tabular}

QUADRO 3.2 - As diferenças entre manufatura e serviço

Fonte : Tabela 1.2 de Normann (1993)

De modo um pouco mais abrangente, Nóbrega (1997) lista várias diferenças entre manufatura e serviço reportadas na literatura, as quais são apresentadas no Quadro 3.3.

De um modo mais específico, Edgett e Parkinson (1993), Kotler (2001) e Lovelock e Gummesson (2005) apontam quatro características fundamentais que distinguem serviços de bens:

- intangibilidade;

- inseparabilidade ou simultaneidade;

- heterogeneidade ou variabilidade;

- perecibilidade ou não-estocabilidade. 


\begin{tabular}{|l|l|}
\hline Manufatura & Serviço \\
\hline Tangibilidade & Intangibilidade \\
\hline Há transferência de posse. & Não há transferência de posse. \\
\hline O produto pode ser revendido. & O serviço não pode ser revendido. \\
\hline O produto pode ser demonstrado. & O serviço não pode ser demonstrado. \\
\hline O produto pode ser estocado. & O serviço não pode ser estocado. \\
\hline Produção antecipada - separabilidade. & Produção simultânea - inseparabilidade. \\
\hline O produto pode ser transportado. & $\begin{array}{l}\text { O serviço não pode ser transportado (os } \\
\text { "produtores" sim). }\end{array}$ \\
\hline $\begin{array}{l}\text { Produção, venda e consumo podem ser feitos } \\
\text { em locais diferentes. }\end{array}$ & $\begin{array}{l}\text { Produção, venda e consumo freqüentemente no } \\
\text { mesmo local. }\end{array}$ \\
\hline Contato indireto com o cliente. & Contato direto com o cliente. \\
\hline Impessoal - homogeneidade. & Pessoal - heterogeneidade. \\
\hline Não há participação do cliente no processo. & O cliente participa do processo. \\
\hline Tecnocrático & Humanístico \\
\hline Estabilidade & Volatilidade \\
\hline Capital intensivo & Trabalho intensivo \\
\hline Centralizado & Descentralizado \\
\hline Massificado & Customizado \\
\hline Muita supervisão & Pouca supervisão \\
\hline Necessário pouco julgamento pessoal. & Necessário muito julgamento pessoal. \\
\hline Tempo de resposta longo. & Tempo de resposta curto. \\
\hline $\begin{array}{l}\text { Projeto do produto visa ao cliente. Projeto do } \\
\text { processo visa ao fornecedor. }\end{array}$ & Ambos visam ao cliente. \\
\hline Facilmente padronizável. & Padronização complexa. \\
\hline Valor principal produzido em fábricas. & $\begin{array}{l}\text { Valor principal produzido em interações entre } \\
\text { comprador e fornecedor. }\end{array}$ \\
\hline Habilidades técnicas. & Habilidades para interagir com público. \\
\hline $\begin{array}{l}\text { Distinção clara entre as funções marketing e } \\
\text { produção. }\end{array}$ & $\begin{array}{l}\text { Superposição entre as funções marketing e } \\
\text { produção. }\end{array}$ \\
\hline & \\
\hline
\end{tabular}

QUADRO 3.3 - As diferenças clássicas entre manufatura e serviço

Fonte : Quadro 2 de Nóbrega (1997)

Lovelock e Gummesson (2005) e Corrêa e Caon (2002) realizaram uma análise crítica destas características nos diferentes tipos de serviços e concluíram que as mesmas não se fazem presentes em todos os tipos de serviços. O Quadro 3.4 indica a presença parcial dessas características nos serviços, à luz da visão de serviços como processo de transformação, relatada no Capítulo 1. 


\begin{tabular}{|c|c|c|c|c|}
\hline Características & $\begin{array}{l}\text { Atos físicos nas } \\
\text { próprias pessoas }\end{array}$ & $\begin{array}{l}\text { Atos físicos nos } \\
\text { objetos físicos das } \\
\text { pessoas }\end{array}$ & $\begin{array}{l}\text { Atos não físicos } \\
\text { nas mentes das } \\
\text { pessoas }\end{array}$ & $\begin{array}{l}\text { Processamento de } \\
\text { informações }\end{array}$ \\
\hline Intangibilidade & \begin{tabular}{|l|} 
Parcialmente certo - \\
a execução pode ser \\
efêmera, mas a \\
experiência pode ser \\
altamente tangível e \\
até resultar em uma \\
mudança física.
\end{tabular} & $\begin{array}{l}\text { Parcialmente certo - } \\
\text { a execução pode ser } \\
\text { efêmera mas pode } \\
\text { transformar } \\
\text { fisicamente os } \\
\text { objetos do cliente } \\
\text { em modos tangíveis. }\end{array}$ & Sim & Sim \\
\hline $\begin{array}{l}\text { Heterogeneidade ou } \\
\text { variabilidade }\end{array}$ & \begin{tabular}{|l|} 
Sim - \\
frequientemente de \\
difícil padronização, \\
por causa do \\
trabalho e do \\
envolvimento direto \\
do cliente.
\end{tabular} & $\begin{array}{l}\text { Existem numerosas } \\
\text { exceções em que } \\
\text { ocorre a } \\
\text { padronização das } \\
\text { atividades. }\end{array}$ & $\begin{array}{l}\text { Existem numerosas } \\
\text { exceções em que } \\
\text { ocorre a } \\
\text { padronização das } \\
\text { atividades. }\end{array}$ & $\begin{array}{l}\text { Existem numerosas } \\
\text { exceções em que } \\
\text { ocorre a } \\
\text { padronização das } \\
\text { atividades. }\end{array}$ \\
\hline $\begin{array}{l}\text { Inseparabilidade ou } \\
\text { simultaneidade }\end{array}$ & Sim & \begin{tabular}{|l|} 
Não - o cliente \\
usualmente não está \\
presente durante a \\
produção.
\end{tabular} & $\begin{array}{l}\text { Apenas quando a } \\
\text { execução for } \\
\text { oferecida ao vivo. }\end{array}$ & $\begin{array}{l}\text { Muitas exceções - } \\
\text { os clientes podem } \\
\text { estar ausentes } \\
\text { durante a produção. }\end{array}$ \\
\hline $\begin{array}{l}\text { Perecibilidade ou não- } \\
\text { estocabilidade }\end{array}$ & Sim & Sim & $\begin{array}{l}\text { Existem numerosas } \\
\text { exceções - a } \\
\text { execução pode ser } \\
\text { estocada na forma } \\
\text { impressa ou } \\
\text { eletrônica. }\end{array}$ & $\begin{array}{l}\text { Existem numerosas } \\
\text { exceções - a } \\
\text { execução pode ser } \\
\text { estocada na forma } \\
\text { impressa ou } \\
\text { eletrônica. }\end{array}$ \\
\hline
\end{tabular}

QUADRO 3.4 - A aplicabilidade das características diferenciadoras dos serviços em diferentes tipos de serviços

Fonte : Baseado na Tabela 2 de Lovelock e Gummesson (2005)

Como sugerido pelos trabalhos de Lovelock e Gummesson (2005) e Corrêa e Caon (2002), apesar da existência de várias propostas de definição das características diferenciadoras entre serviços e bens ou entre indústria de serviços e indústria manufatureira, constata-se que ainda não se conseguiu estabelecer características diferenciadoras que possam ser observadas em todos os tipos de serviços. 


\subsection{TIPOLOGIAS DE SERVIÇOS}

Uma tipologia ou classificação dos serviços auxilia sua administração, ao identificar problemas e características que são comuns a cada grupo. Portanto, ao agrupar diferentes empresas por características comuns, o administrador de serviço poderá aplicar os mesmos conceitos a essas organizações.

Cook; Goh e Chung (1999) analisaram as mais diversas classificações de serviços e identificaram alguns padrões:

- algumas classificações revelam uma visão mais macro (tipicamente as classificações realizadas por economistas) enquanto outras revelam uma visão mais micro (tipicamente as classificações oriundas das áreas de operações e marketing de serviços);

- algumas classificações são orientadas para o mercado enquanto outras são orientadas para a operação. As primeiras normalmente são oriundas do marketing de serviços e as últimas são oriundas da área de operações de serviços.

Baseando-se no trabalho de Cook; Goh e Chung (1999), serão apresentadas, primeiramente, as classificações de serviços com a visão macro e, posteriormente, com a visão micro.

\subsubsection{Classificações de serviços na visão macro}

Kon (2004) desenvolveu uma extensa análise das diferentes classificações existentes nos serviços, exposta nos Quadros 3.5 e 3.9. 


\begin{tabular}{|c|c|}
\hline \multirow{3}{*}{$\begin{array}{l}\text { Classificação baseada na produção de } \\
\text { acordo com Fisher-Clark (1935/40) }\end{array}$} & Primário (agricultura e mineração) \\
\hline & Secundário (manufatura) \\
\hline & Terciário \\
\hline \multirow{2}{*}{$\begin{array}{l}\text { Classificação baseada na produção de } \\
\text { acordo com Sabolo (1975) }\end{array}$} & Primário: agricultura, criação de gado e pesca. \\
\hline & $\begin{array}{l}\text { Não-primário: Transporte, mineração e manufatura (alto uso de capital e } \\
\text { qualificações); Comércio (baixo uso de capital e qualificações); Financeiros } \\
\text { (alto uso de qualificações, baixo uso de capital) }\end{array}$ \\
\hline \multirow{3}{*}{$\begin{array}{l}\text { Classificação baseada na produção de } \\
\text { acordo com Fuchs (1968) }\end{array}$} & Agricultura \\
\hline & Indústria (mineração, manufatura, transportes, utilidades) \\
\hline & Serviços (comércio, empresariais, governo) \\
\hline \multirow{3}{*}{$\begin{array}{l}\text { Classificação baseada na produção de } \\
\text { acordo com o Banco Mundial (1980) }\end{array}$} & Primário (agricultura e mineração) \\
\hline & $\begin{array}{l}\text { Secundário (manufatura, mineração, construção de serviços de utilidade } \\
\text { pública compostos por serviços públicos de distribuição de gás, eletricidade } \\
\text { e água) }\end{array}$ \\
\hline & Terciário \\
\hline \multirow{3}{*}{$\begin{array}{l}\text { Classificação baseada na função de } \\
\text { acordo com Foot e Hatt (1953) }\end{array}$} & Terciário (restaurante, hotéis, reparação e manutenção, lavanderia) \\
\hline & Quaternário (transporte, comunicação, comércio, financeiro) \\
\hline & Quinário (saúde, educação, recreação) \\
\hline \multirow{4}{*}{$\begin{array}{l}\text { Classificação baseada na função de } \\
\text { acordo com a ONU (1968) }\end{array}$} & Comércio, alojamento e alimentação \\
\hline & Transporte e comunicação \\
\hline & Atividades financeiras, bens imóveis e serviços às empresas \\
\hline & Serviços comunitários, sociais e pessoais \\
\hline \multirow{3}{*}{$\begin{array}{l}\text { Classificação baseada na função de } \\
\text { acordo com Katouzian (1970) }\end{array}$} & Serviços complementares (financeiro, transporte, comércio) \\
\hline & Serviços novos (saúde, educação, entretenimento) \\
\hline & Serviços antigos (domésticos) \\
\hline \multirow{4}{*}{$\begin{array}{l}\text { Classificação baseada na função de } \\
\text { acordo com Browning e Singleman } \\
\text { (1975) }\end{array}$} & $\begin{array}{l}\text { Serviços distributivos (transporte, comunicação, comércio atacadista e } \\
\text { varejista) }\end{array}$ \\
\hline & $\begin{array}{l}\text { Serviços às empresas (financeiros, imobiliários, legais, de contabilidade, } \\
\text { engenharia e outros profissionais) }\end{array}$ \\
\hline & Serviços sociais (saúde, educação, defesa, correio, governo e outros sociais) \\
\hline & $\begin{array}{l}\text { Serviços pessoais (domésticos, hotéis, restaurantes, lazer, reparação e } \\
\text { outros pessoais) }\end{array}$ \\
\hline \multirow{4}{*}{$\begin{array}{l}\text { Classificação de acordo com o } \\
\text { Departamento de Comércio dos Estados } \\
\text { Unidos (U.S. Census Bureau) (1984) }\end{array}$} & Transporte, comunicação e utilidades públicas \\
\hline & Comércio varejista e atacadista \\
\hline & Financeiros, seguros e imobiliários \\
\hline & Serviços pessoais e às empresas \\
\hline \multirow{3}{*}{$\begin{array}{l}\text { Classificação de acordo com Singer } \\
\text { (1981) }\end{array}$} & Serviços às empresas \\
\hline & De consumo coletivo \\
\hline & De consumo individual \\
\hline
\end{tabular}

QUADRO 3.5 - Diferentes classificações de serviços

Fonte : Baseado no Quadro 2.1 de Kon (2004) 
Classe 1: O produto do sistema é consumido simultaneamente com sua produção, como no caso de tratamento médico, cabeleireiro, cinema, entre outros.

Classe 2: O produto do sistema é a informação ou energia que pode ser estocada em algum equipamento para uso posterior, como no caso de uma firma de assessoria que estoca resultados de pesquisas em arquivos ou disquetes de computador e os vende em outro período, ou ainda uma empresa de distribuição de gás engarrafado.

Classe 3: A produção do sistema fornece atividades de apoio que facilitam a atividade de uma outra empresa ou família, como no caso da decoração de interiores, atividades financeiras, consultoria, transportes e comunicações, entre outras. Na maior parte das vezes, a definição das atividades de serviços é formulada como complementação das atividades econômicas de um sistema produtivo, como o que não constou nas atividades que não compõem os setores de manufatura, extração vegetal e mineral e o setor primário.

QUADRO 3.6 - Definição de Murdock das classes de serviços

Fonte : Baseado no Quadro 2.3 de Kon (2004)

Serviços envolvidos na produção de bens: Serviços que têm um produto material. Eles incluem trabalhadores diretamente envolvidos na produção de bens, isto é, fora da linha de produção da indústria manufatureira, bem como os fornecedores de serviços às empresas, por exemplo, de administração, de atividades pré-produção, como pesquisa, planejamento, consultoria etc., e de pós-produção, como de reparação e manutenção.

Serviços envolvidos na circulação de bens: Transferência de bens, trabalho, dinheiro e informação, como serviços financeiros, de transportes, comunicações, telecomunicações, distribuição atacadista, comércio varejista e serviços relacionados à propriedade.

Serviços de trabalho: Processos de trabalho completos que não produzem um produto físico. Incluem várias formas de serviços de aconselhamento cujo produto é intangível, como serviços médicos, legais e outras formas de aconselhamento profissional; abrangem ainda funcionários de vendas presentes em apresentações de teatro e concertos, em serviço doméstico e em ensino.

Servicos do Estado: Atividades do governo central e local.

QUADRO 3.7 - Tipologia de Walker sobre as funções de serviços

Fonte : Baseado no Quadro 2.4 de Kon (2004)

Serviços de processamento de informações: Pesquisa e desenvolvimento de produto/processo. Marketing, vendas, publicidade, pesquisa de mercado, fotografia e mídia. Engenharia (civil, mecânica, química, elétrica etc.) e desenho arquitetônico. Serviços de computação, consultoria de gerenciamento, administração. Planejamento financeiro, contabilidade, gerenciamento de investimentos, auditoria, instituições bancárias e financeiras. Seguros. Legais. Treinamento e educação do pessoal e relações industriais, compras, serviços de escritórios. Agentes de administração de propriedades e imóveis.

Serviços relacionados a bens: Distribuição e armazenagem de bens, atacadistas, eliminação de restos industriais, administração de transportes. Instalação, manutenção e reparação de equipamentos (incluindo veículos), redes de comunicações e utilidades públicas. Manutenção de edifícios e da infra-estrutura.

Serviços de apoio ao pessoal: Serviços de saúde, limpeza, domésticos, segurança, seguros, acomodação e transporte pessoal.

QUADRO 3.8 - Classificação de Marshall sobre serviços às empresas

Fonte : Baseado no Quadro 2.5 de Kon (2004) 


\begin{tabular}{|c|c|}
\hline Função & Composição \\
\hline $\begin{array}{l}\text { Manufatura } \\
\text { (processamento de } \\
\text { matérias-primas) }\end{array}$ & 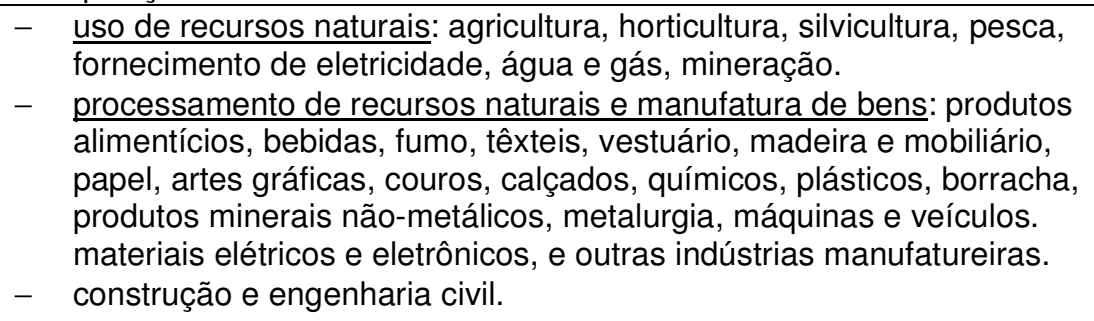 \\
\hline $\begin{array}{l}\text { Circulação (papel } \\
\text { intermediário no fluxo } \\
\text { físico de pessoas, bem } \\
\text { como nos fluxos de } \\
\text { informações, } \\
\text { comunicações e } \\
\text { financeiros) }\end{array}$ & $\begin{array}{l}\text { - } \frac{\text { fluxos físicos, fluxos de pessoas: comércio atacadista, corretagem, }}{\text { transportes. }} \\
\text { - } \frac{\text { fluxos de comunicaccão e informaccão: transmissão da informação, }}{\text { processamento da informação. }} \\
\text { - } \quad \text { fluxos financeiros: bancários, seguros, companhias financeiras. }\end{array}$ \\
\hline $\begin{array}{l}\text { Distribuição } \\
\text { (fornecimento de bens e } \\
\text { serviços diretamente a } \\
\text { consumidores finais) }\end{array}$ & $\begin{array}{l}\text { - saúde, educação, comércio varejista, hotéis e restaurantes, reparação } \\
\text { de itens de consumo e veículos, serviços pessoais, serviços de } \\
\text { cultura, esportes e lazer, serviços domésticos. }\end{array}$ \\
\hline $\begin{array}{l}\text { Regulação (assegura a } \\
\text { operação fluente global } \\
\text { do sistema produtivo e } \\
\text { sua manutenção, } \\
\text { modificação e } \\
\text { monitoramento) }\end{array}$ & $\begin{array}{ll}\text { - } & \text { administração pública: federal, estadual, municipal. } \\
\text { - } & \text { organizações privadas: de previdência social, religiosas, sociais e } \\
\text { culturais, serviços comunitários e grupos de interesses comuns, } \\
\text { administração de serviços rodoviários e de saneamento. } \\
\text { - } \quad \text { organizações diplomáticas internacionais. }\end{array}$ \\
\hline
\end{tabular}

QUADRO 3.9 - Classificação de serviços segundo funções

Fonte : Baseado na Quadro 2.8 de Kon (2004)
Serviços de consumo: São aqueles prestados diretamente ao consumidor final. Nesta categoria, subdividem-se em:
- de conveniência - quando o consumidor não quer perder tempo em procurar a empresa. É o caso de tinturarias, sapatarias e empresas de pequenos consertos;
- de escolha - caracteriza-se quando alguns serviços têm custos diferenciados de acordo com a qualidade e o tipo de serviços prestados, prestígio da empresa, etc. São prestados por bancos, seguradoras, empresas de pesquisas, etc.;
- de especialidade - são altamente técnicos e especializados. São prestados por especialistas como médicos, advogados, técnicos, etc.

Serviços industriais: São aqueles prestados a organizações industriais, comerciais ou institucionais. Nesta categoria, subdividem-se em:

- de equipamentos - relacionados com instalação, montagem de equipamentos ou manutenção;

- de facilidade - serviços financeiros, de seguros, etc., que facilitam as operações da empresa;

- de consultoria/orientação - são os que auxiliam nas tomadas de decisão e incluem serviços de consultoria, pesquisa e educação.

QUADRO 3.10 - Classificação de serviços considerando o esforço do consumidor para sua obtenção Fonte : Las Casas (1991) 


\subsubsection{Classificações de serviços na visão micro}

Um dos primeiros trabalhos sobre tipologia de serviço foi realizado por Chase (1978). Ele propõe classificar os diferentes serviços utilizando-se a variável grau de contato do cliente com o sistema. Essa dimensão baseia-se no tempo de contato do primeiro com o segundo. Mais especificamente, refere-se ao percentual de período que o cliente permanece em contato com o sistema sobre o prazo total necessário para realizar esse processo. Os sistemas podem ser classificados como serviços puros (alto contato), mistos (médio contato) ou quase manufatura (baixo contato). Considerando esta variável, Chase (1978) define as principais características que devem ser consideradas para se desenvolver um serviço. O Quadro 3.11 ilustra as principais implicações para o design de operações de serviços conforme o grau de contato (baixo ou alto) do cliente com o sistema.

\begin{tabular}{|c|c|c|}
\hline $\begin{array}{l}\text { Considerações de } \\
\text { design }\end{array}$ & Operações de alto contato & Operações de baixo contato \\
\hline $\begin{array}{l}\text { Localização da } \\
\text { instalação }\end{array}$ & As operações devem estar próximas do cliente. & $\begin{array}{l}\text { As operações podem estar próximas dos } \\
\text { fornecedores, dos transportadores ou da mão-de- } \\
\text { obra. }\end{array}$ \\
\hline Leiaute da instalação & $\begin{array}{l}\text { A instalação deve se ajustar às necessidades e } \\
\text { expectativas físicas e psicológicas dos clientes. }\end{array}$ & A instalação deve racionalizar a produção. \\
\hline $\begin{array}{l}\text { Design dos elementos } \\
\text { tangíveis do serviço }\end{array}$ & $\begin{array}{l}\text { O ambiente, assim como as características físicas } \\
\text { dos tangíveis, definem a natureza do serviço. }\end{array}$ & O cliente não está presente no ambiente do serviço. \\
\hline Design do processo & $\begin{array}{l}\text { Os estágios do processo de produção têm efeito } \\
\text { imediato e direto sobre o cliente. }\end{array}$ & $\begin{array}{l}\text { O cliente não se envolve na maioria das etapas do } \\
\text { processo. }\end{array}$ \\
\hline Programação & $\begin{array}{l}\text { O cliente faz parte do programa de produção e deve } \\
\text { ser acomodado. }\end{array}$ & $\begin{array}{l}\text { O cliente está preocupado principalmente com as } \\
\text { datas de finalização. }\end{array}$ \\
\hline $\begin{array}{l}\text { Planejamento da } \\
\text { produção }\end{array}$ & $\begin{array}{l}\text { Os pedidos não podem ser estocados quando a } \\
\text { demanda supera a capacidade de produção, pois } \\
\text { essa prática pode levar à perda do negócio. }\end{array}$ & É possível estocar os pedidos. \\
\hline $\begin{array}{l}\text { Habilidades dos } \\
\text { trabalhadores }\end{array}$ & $\begin{array}{l}\text { A mão-de-obra direta compõe uma parte importante } \\
\text { do serviço do produto, devendo ser capaz de interagir } \\
\text { satisfatoriamente com o público. }\end{array}$ & $\begin{array}{l}\text { A mão-de-obra direta precisa apenas ter habilidades } \\
\text { técnicas. }\end{array}$ \\
\hline Controle da qualidade & $\begin{array}{l}\text { Os padrões de qualidade estão nas percepções do } \\
\text { observador e, assim, são variáveis. }\end{array}$ & $\begin{array}{l}\text { Os padrões de qualidade geralmente são } \\
\text { mensuráveis e, então, podem ser especificados. }\end{array}$ \\
\hline Padrões de prazos & $\begin{array}{l}\text { O tempo do serviço depende da necessidade dos } \\
\text { clientes; por isso, não se consegue manter um padrão } \\
\text { rígido de prazos. }\end{array}$ & $\begin{array}{l}\text { O trabalho é desenvolvido com substitutos dos } \\
\text { clientes (por exemplo, documentos), e os padrões de } \\
\text { prazos podem ser estabelecidos. }\end{array}$ \\
\hline Salários & $\begin{array}{l}\text { A produção variável requer um sistema salarial com } \\
\text { base no tempo. }\end{array}$ & $\begin{array}{l}\text { A produção "fixa" permite um sistema salarial com } \\
\text { base na produção. }\end{array}$ \\
\hline $\begin{array}{l}\text { Planejamento da } \\
\text { capacidade }\end{array}$ & $\begin{array}{l}\text { Para evitar perdas nas vendas, a capacidade deve } \\
\text { ser fixada de acordo com os picos de demanda. }\end{array}$ & $\begin{array}{l}\text { A possibilidade de estocar a produção torna possível } \\
\text { estipular a capacidade de acordo com um } \\
\text { determinado nível médio de demanda. }\end{array}$ \\
\hline Previsão & $\begin{array}{l}\text { As previsões são de curto prazo e orientadas pelo } \\
\text { tempo. }\end{array}$ & $\begin{array}{l}\text { As previsões são de longo prazo e orientadas pela } \\
\text { produção. }\end{array}$ \\
\hline
\end{tabular}

QUADRO 3.11 - Classificação de serviços proposta por Chase (1978)

Fonte : Baseado na Tabela II de Chase (1978) 
Lovelock (1983) desenvolveu cinco diferentes classificações de serviços, as quais possibilitam obter insights estratégicos, ajudando o gestor a sair da lógica industrialista, fortemente presente na teoria sobre gestão de operações. As classificações propostas são descritas a seguir:

a) Natureza do ato do serviço: Analisa os diferentes tipos de serviço sob a ótica de processos. Consideram-se duas dimensões: quem ou o que é beneficiário direto do serviço e sua natureza tangível (Figura 3.1).

Beneficiário direto do serviço

Pessoas Objetos

\begin{tabular}{|c|c|c|}
\hline Atos tangíveis & $\begin{array}{l}\text { Serviços dirigidos ao corpo: } \\
\text { - Saúde } \\
\text { - Transporte de passageiros } \\
\text { - Salões de beleza } \\
\text { - Restaurantes }\end{array}$ & $\begin{array}{l}\text { Serviços dirigidos a produtos e outros bens } \\
\text { físicos: } \\
\text { - Transporte de carga } \\
\text { - Reparo e manutenção } \\
\text { - Lavanderia e lavagem a seco } \\
\text { - Cuidados veterinários }\end{array}$ \\
\hline $\begin{array}{c}\text { Atos } \\
\text { intangíveis }\end{array}$ & $\begin{array}{l}\text { Serviços dirigidos à mente: } \\
\text { - Educação } \\
\text { - Radiofusão } \\
\text { - Serviços de informações } \\
\text { - Teatros } \\
\text { - Museus }\end{array}$ & $\begin{array}{l}\text { Serviços dirigidos a ativos intangíveis: } \\
\text { - Bancos } \\
\text { - Serviços legais } \\
\text { - Contabilidade } \\
\text { - Valores mobiliários } \\
\text { - Seguros }\end{array}$ \\
\hline
\end{tabular}

FIGURA 3.1 - Entendendo a natureza do serviço prestado

Fonte : Baseada na Figura 1 de Lovelock (1983)

b) Relacionamento com os clientes: Avalia os diferentes serviços em relação a sua capacidade de construir relacionamentos de longo prazo com o cliente. Consideram-se duas dimensões: natureza do serviço prestado - se contínua ou por meio de transações não-contínuas - e o tipo de relacionamento entre a organização e seus clientes (Figura 3.2). 
Tipo de relacionamento entre a organização de serviço e seus clientes

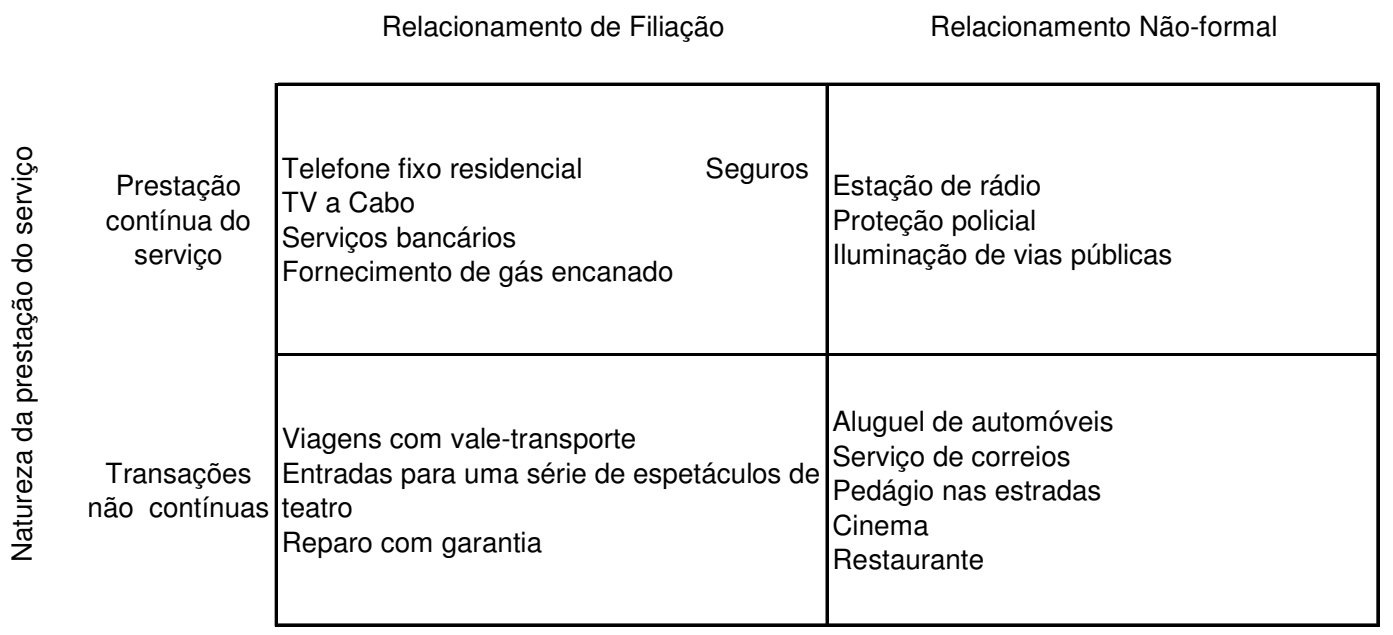

\section{FIGURA 3.2 - Relacionamento com os clientes}

Fonte : Baseada na Figura 2 de Lovelock (1983)

c) Personalização e julgamento: Indica como os serviços são criados à medida que são consumidos. Como o cliente é freqüentemente participante do processo, existe a oportunidade de adaptá-lo às suas necessidades. Consideram-se duas dimensões: o grau em que o serviço permite a personalização e o grau com que o prestador de serviço pode modificar a natureza do serviço prestado (Figura 3.3).

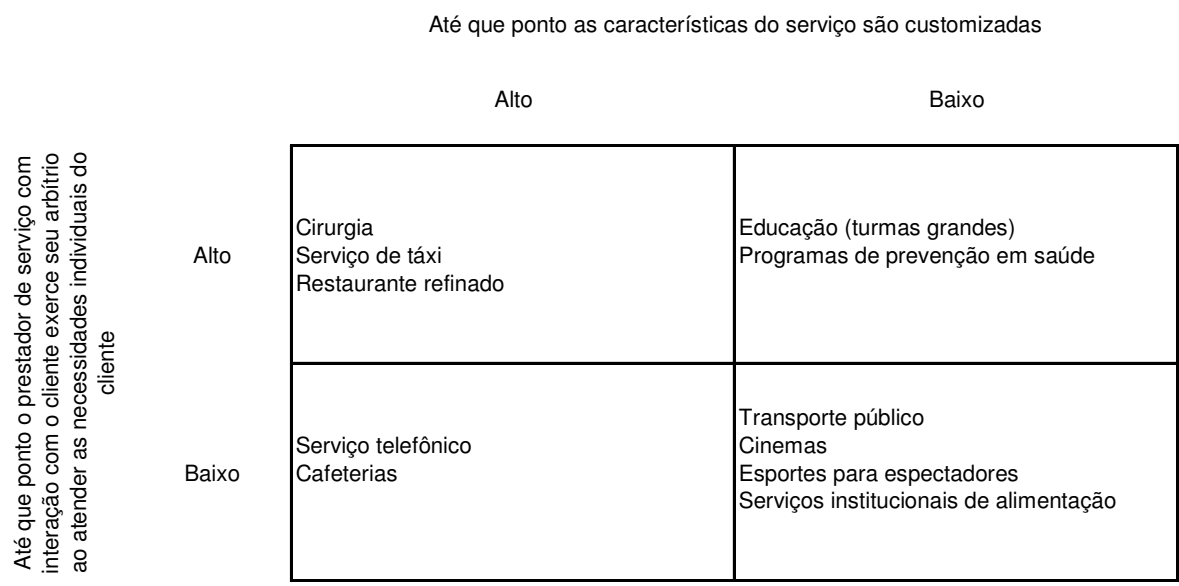

FIGURA 3.3 - Personalização e julgamento na prestação de serviços

Fonte : Baseada na Figura 3 de Lovelock (1983) 
d) Natureza da demanda e fornecimento: Analisa os serviços levando em consideração sua perecibilidade, que remete ao desafio gerencial da gestão da capacidade em sistemas de serviços. Duas variáveis são analisadas: grau de restrição do fornecimento e a faixa de flutuação da demanda (Figura 3.4).

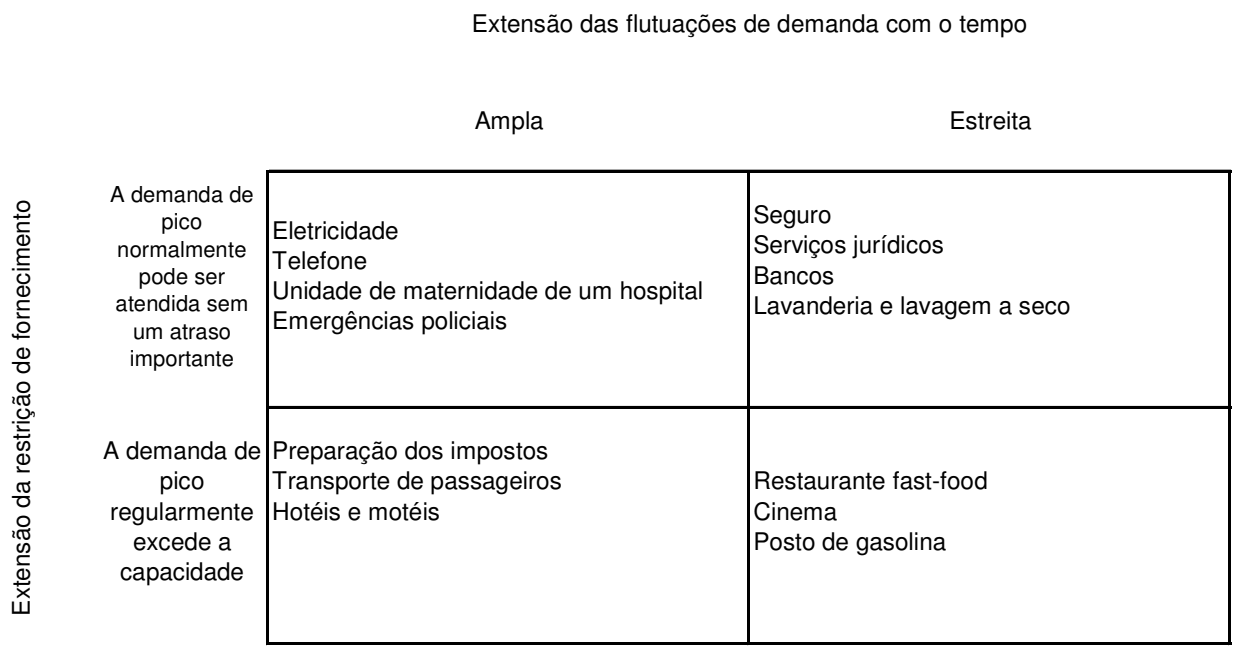

FIGURA 3.4 - Natureza da demanda e fornecimento

Fonte : Baseada na Figura 4 de Lovelock (1983)

e) Método de atendimento em serviços: Leva em consideração a necessidade de interação física entre o cliente e a empresa, e a existência ou não de múltiplas localizações. Duas variáveis são utilizadas: natureza da interação entre o cliente e a organização de serviços, e disponibilidade de pontos de serviço (Figura 3.5). 
Disponibilidade de locais de prestação de serviços

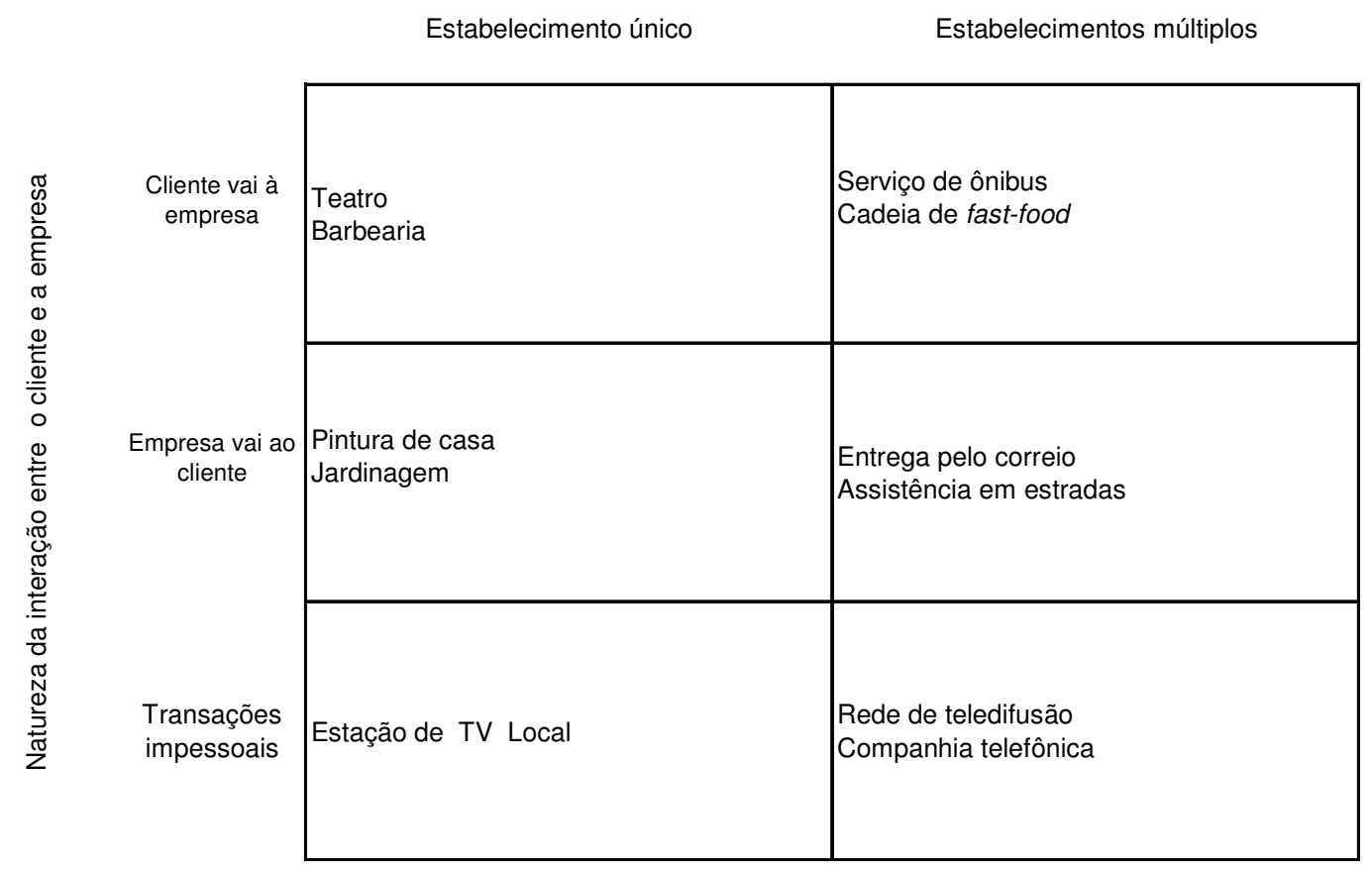

FIGURA 3.5 - Método de atendimento em serviços

Fonte : Baseada na Figura 5 de Lovelock (1983)

Schmenner (1986) propõe classificar os serviços utilizando-se de duas dimensões: grau de intensidade de mão-de-obra (refere-se à razão do custo da mãode-obra sobre o valor da instalação e equipamentos, desconsiderando o custo de inventário) e grau de interação e personalização (refere-se ao grau de interação do cliente com o processo de serviço e ao grau de customização do serviço para o cliente). A partir dessa classificação, Schmenner (1986) aponta os principais desafios para a gestão de operações de serviços (Figura 3.6). 


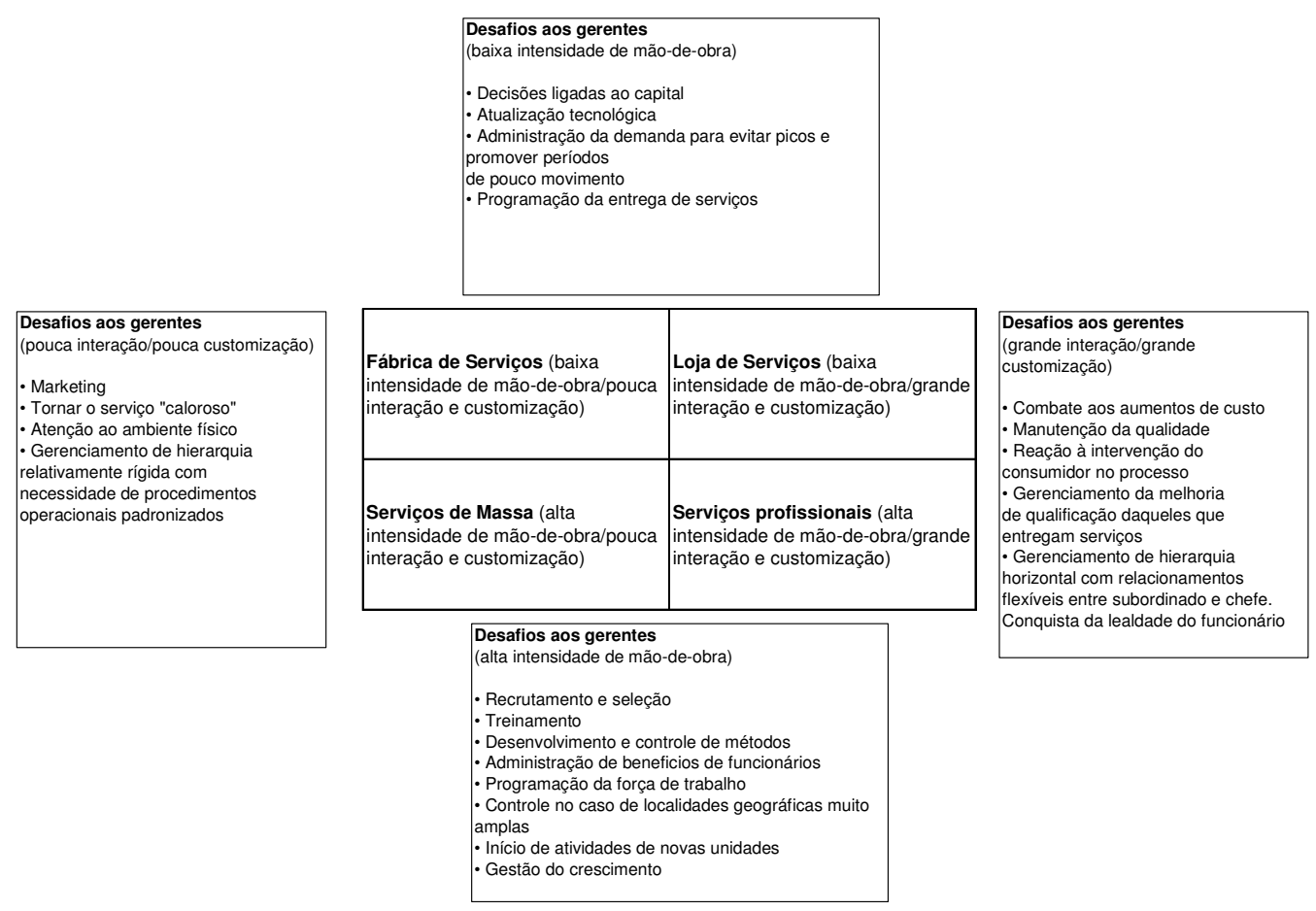

FIGURA 3.6 - Classificação de serviços proposta por Schmenner (1986)

Fonte : Baseada na Figura II de Schmenner (1986)

Shostack (1987) sugere que existem duas variáveis-chave para descrever um processo de serviço: a complexidade do processo e a divergência. A complexidade refere-se ao número de passos necessários para completar um processo de serviço e a divergência refere-se ao grau de variação permitido na execução dos passos de um processo de serviço.

A participação do cliente no processo de prestação de serviço aumenta a incerteza existente na operação. Pode-se definir incerteza como a diferença entre a quantidade de informação requerida para realizar tarefas e a efetivamente possuída pela organização. Larsson e Bowen (1989) observaram que a participação do cliente no processo de prestação de serviço cria incertezas geradas por duas fontes:

- Diversidade de demanda: refere-se às especificidades das demandas dos clientes. Quanto maior a diversidade das demandas dos clientes maior a quantidade de informação não possuída pela organização, antes do encontro com aqueles. Esta dimensão refere-se à distinção entre 
customização e padronização encontrada na literatura. Representa as condições ambientais que as organizações enfrentam, para as quais podem responder com projetos de serviço mais ou menos personalizados. - Disposição do cliente em participar: refere-se à extensão com que o cliente tende a ter um papel ativo com seu trabalho ou informação para o processo de fornecimento do serviço. Quanto mais ações o primeiro tende a contribuir, maior é a incerteza fornecida porque a organização tem uma informação incompleta acerca do que ele fará antes do encontro. A disposição para participar pode ter duas motivações: i) clientes acham intrinsecamente interessante participar; ii) eles percebem que seu envolvimento é necessário para garantir a qualidade do serviço. A sua disposição pode ser restringida por falta de habilidade (em termos de conhecimento ou condições físicas ou disponibilidade de tempo) ou pelo desconhecimento do seu papel como co-produtor.

Para Larsson e Bowen (1989), a diversidade da demanda e a disposição do cliente em participar constituem uma fonte de incerteza para o processo de serviço. Estas duas variáveis são externas às organizações e implicam em restrições às quais o projeto de serviço deve se adaptar. Mas a organização pode influenciá-las, por exemplo, pelo marketing. No que tange ao projeto das operações, este deve contemplar decisões fundamentais como: i) a divisão do trabalho entre os funcionários e os clientes; ii) personalização versus padronização das atividades do serviço. Com base nas variáveis "diversidade da demanda" e "disposição do cliente em participar", Larsson e Bowen (1989) propõem uma tipologia sobre as implicações destas variáveis para o projeto de serviços, conforme ilustra a Figura 3.7. 


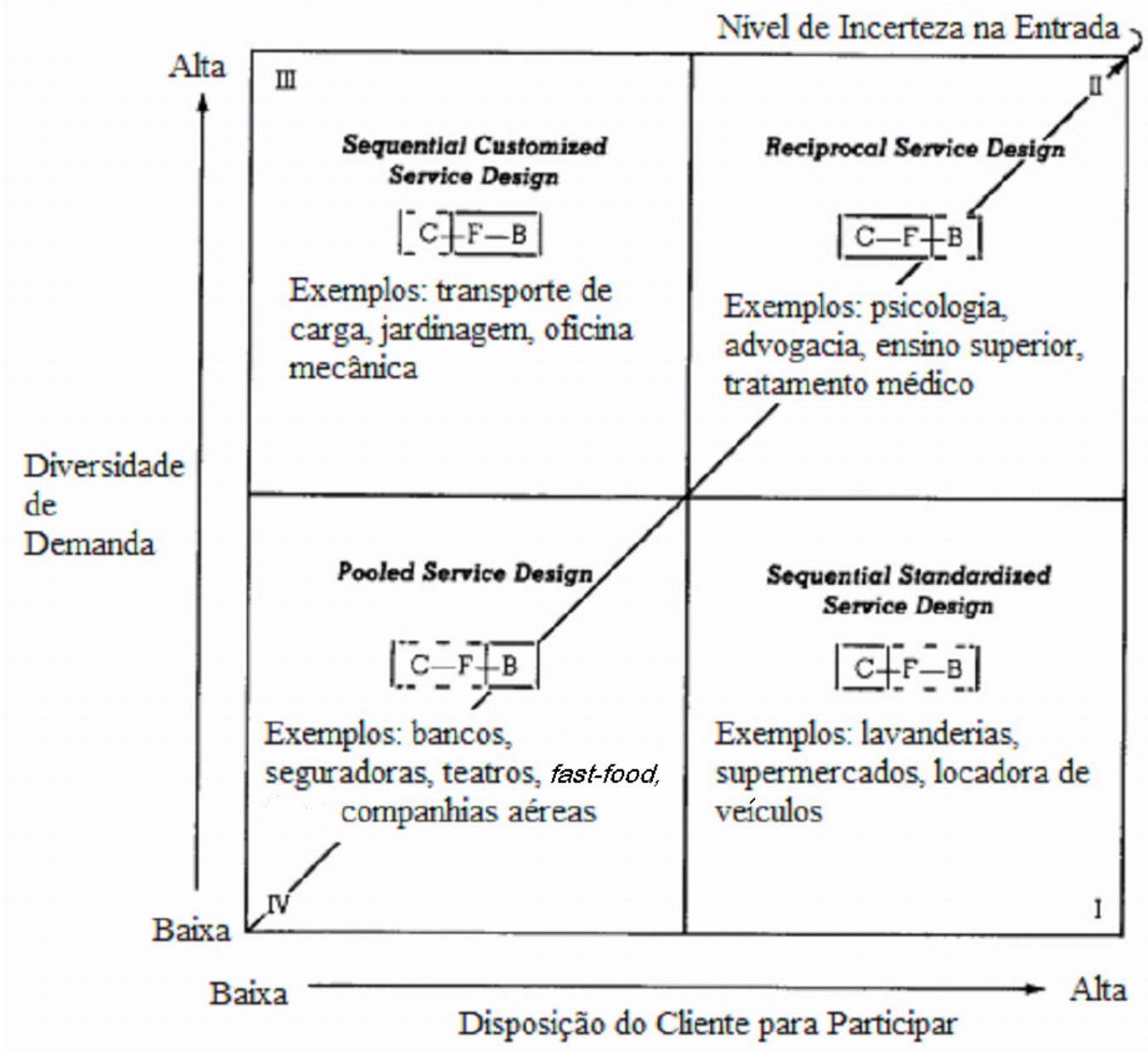

Legenda

$\mathrm{C}=$ Clientes

$\mathrm{F}=$ Funcionários Front-Office

$\mathrm{B}=$ Funcionários Back-Office

EI= Principal local de interdependências

[- II: Interdependências de apoio

FIGURA 3.7 - Implicações das variáveis diversidade da demanda e disposição do cliente em participar

Fonte : Baseada na Figura 2 de Larsson e Bowen (1989)

O quadrante I refere-se a situações onde existe uma alta disposição do cliente em participar do processo e há uma baixa diversidade de demanda. Os serviços "faça você mesmo" se enquadram nesse ponto. São processos de alto volume, baixa variedade, com atividades corriqueiras e repetitivas, mas com altos níveis de 
envolvimento do cliente. A área de decisão-chave localiza-se em torno do cliente. Grande carga de trabalho pode ser alocada sob a responsabilidade do cliente se este tiver habilidades e informações adequadas sobre o seu papel. Espera-se que o cliente seja mais sensível ao preço, de modo que o baixo valor constitua um incentivo a sua participação, ou que a motivação ocorra a partir da possibilidade de se obter um controle maior sobre o serviço. A padronização possibilita uma independência maior entre o front-office e o back-office.

O quadrante II refere-se às situações em que há alta disposição do cliente em participar do processo e alta diversidade de demanda. Em razão do vínculo tão direto entre cliente e o prestador do serviço, a sua eficácia é freqüentemente uma função da "química" entre os indivíduos envolvidos. A área de decisão-chave está em torno do cliente e na parceria do pessoal do front-office. Normalmente, o próprio cliente é processado, o que o motiva a participar ativamente do processo.

O quadrante III refere-se às situações onde há baixa disposição do cliente em participar do processo e alta diversidade de demanda. Muitos serviços são adquiridos por mera conveniência, por falta de tempo ou porque são tidos como "inferiores". A área de decisão-chave volta-se para os funcionários da empresa. O pessoal do front-office deve captar as especificações do serviço que será realizado pelo pessoal do back-office. Algumas vezes, uma única pessoa realiza o papel de front-office e back-office.

O quadrante IV refere-se às situações nas quais há baixa disposição do cliente em participar do processo e há uma baixa diversidade de demanda. $\mathrm{A}$ área de decisão-chave para esses serviços está na retaguarda, onde as principais tarefas devem ser eficientes e consistentes. O pessoal do front-office deve fazer com que o processo pareça amigável e dar a impressão de que cada cliente é valioso e especial.

Um aspecto importante para a prestação do serviço é a relevância do papel do script do cliente. Representa o conhecimento que aquele deve ter para a efetiva participação na produção. O desconhecimento ou conhecimento parcial por parte dos clientes pode levá-los a duas situações: i) eles devem improvisar o que fazer, ii) os funcionários devem informar o que deve ser feito. Estas duas situações parecem 
arriscadas para a organização e para o cliente. Basicamente, o script do cliente difere em duas dimensões: i) tamanho do papel que a organização quer que o cliente assuma; ii) flexibilidade ou liberdade para improvisar, ou seja, se o encontro do serviço será solto ou estritamente definido. De um modo geral, as empresas necessitam de scripts maiores quando lidam com uma alta disposição do cliente para participar e admitem mais liberdade de script para situações de alta diversidade de demanda (LARSSON e BOWEN, 1989).

Tomando como base a tipologia exposta anteriormente e considerando os mecanismos de coordenação do relacionamento entre o pessoal do front-office e os clientes, quatro diferentes situações emergem:

- Servicos do quadrante I: requerem scripts maiores e estritamente definidos. Os clientes necessitam de uma clara definição do seu papel central, dentro do limites das rotinas previamente estabelecidas para a entrega dos serviços previstos;

- Serviços do quadrante II: requerem scripts maiores e soltos. O ajuste mútuo de informação entre o pessoal de front-office e o cliente é o principal mecanismo de controle. Envolve uma contínua troca de informação nova ou feed-back entre as partes;

- Serviços do quadrante III: requerem scripts menores e soltos;

- Serviços do quadrante IV: requerem scripts menores e estritamente definidos. O script do cliente é, em grande parte, transmitido pela imitação de comportamento.

Wemmerlöv (1990) propõe uma taxonomia para serviços considerando as seguintes variáveis:

- Contato com o cliente: A literatura revela a importância do contato do cliente para a eficiência das operações, mas esta dimensão precisa ser melhor especificada, pois as definições existentes não são muito claras. Nesta direção, o autor define que os contatos entre o sistema de serviço e o cliente podem ser de três tipos:

i) Contato direto do cliente: O cliente está fisicamente presente durante o processo e tem a percepção da criação deste serviço 
pelos seus sentidos. Duas subcategorias podem ser desdobradas deste tipo de contato: a) serviços sem interação com os trabalhadores (serviços do tipo self-service), b) serviços com interação com os trabalhadores do serviço;

ii) Contato indireto do cliente: $O$ contato se processa por intermédio de uma mídia (telefone, telex, fax, e-mail, internet);

iii) Sem contato com o cliente: Não ocorre contato algum entre o processo de serviço e o cliente.

A interação direta do cliente com o processo, por um lado, cria um potencial risco de perturbação da operação; por outro, pode-se tirar vantagem desta participação envolvendo a clientela como um recurso que contribui para a capacidade produtiva. Os processos cujos clientes têm um contato indireto ou nenhum contato com o sistema de serviço podem ser projetados na lógica predominante de busca da eficiência.

- Grau de rotinização: Refere-se à tecnologia na qual os processos estão baseados. Divide-se em dois tipos:

i) processos rígidos de serviços: normalmente exibem baixa variedade de tarefas e requerem um nível menor de habilidade técnica. Pouca informação é requerida entre o sistema e o cliente para realização do serviço e o volume de processamento normalmente é elevado;

ii) Processos fluidos de serviços: Normalmente, requerem um nível maior de habilidade técnica e troca de grande quantidade de informação entre o sistema e o cliente para determinar e realizar o serviço; o volume de processamento normalmente é baixo e o fluxo de trabalho não previsto pode ser alto.

- Objetivos do processo de serviço: o serviço pode ser realizado com o propósito de processar coisas, pessoas ou informações. As coisas transportadas ou transformadas - podem ter duas origens: bens do cliente ou coisas fornecidas pela organização. 
O Quadro 3.12 sintetiza a tipologia de serviços proposta por Wemmerlöv (1990).

\begin{tabular}{|c|c|c|c|c|c|c|c|}
\hline \multirow{2}{*}{\multicolumn{2}{|c|}{ Grau de contato com o cliente }} & \multicolumn{3}{|c|}{ Processos Rígidos de Serviço } & \multicolumn{3}{|c|}{ Processos Fluídos de Serviço } \\
\hline & & Processamento de bens & $\begin{array}{l}\text { Processamento de } \\
\text { informações }\end{array}$ & $\begin{array}{l}\text { Processamento de } \\
\text { pessoas }\end{array}$ & Processamento de bens & $\begin{array}{l}\text { Processamento de } \\
\text { informações }\end{array}$ & $\begin{array}{l}\text { Processamento de } \\
\text { pessoas }\end{array}$ \\
\hline \multicolumn{2}{|c|}{ Nenhum contato com o cliente } & $\begin{array}{l}\text { Lavagem a seco; } \\
\text { Reabastecimento } \\
\text { de uma máquina de } \\
\text { venda automática. }\end{array}$ & $\begin{array}{l}\text { Processamento } \\
\text { de cheques; } \\
\text { Cobrança de um } \\
\text { cartão de crédito }\end{array}$ & & $\begin{array}{l}\text { Manutenção de carros; } \\
\text { Corte de um terno. }\end{array}$ & $\begin{array}{l}\text { Programação de } \\
\text { computadores; Projeto } \\
\text { de um prédio. }\end{array}$ & \\
\hline \multicolumn{2}{|c|}{ Contato indireto com o cliente } & & \begin{tabular}{|l|} 
Fazer pedidos a um \\
supermercado a partir \\
de um computador \\
pessoal; Verificar o \\
saldo de uma conta \\
pelo telefone. \\
\end{tabular} & & & $\begin{array}{l}\text { Supervisionar um pouso } \\
\text { por um controlador } \\
\text { aéreo; Fazer uma oferta } \\
\text { em um leilão pela } \\
\text { televisão. }\end{array}$ & \\
\hline \multirow{2}{*}{$\begin{array}{l}\text { Contato direto } \\
\text { com o cliente }\end{array}$} & $\begin{array}{l}\text { Não há interação } \\
\text { entre o cliente e o } \\
\text { prestador do serviço } \\
\text { (selí-service). }\end{array}$ & $\begin{array}{l}\text { Operar uma máquina } \\
\text { automática; Montar um } \\
\text { móvel pré-fabricado }\end{array}$ & $\begin{array}{l}\text { Retirar dinheiro de um } \\
\text { caixa eletrônico de um } \\
\text { banco; Tirar fotos em } \\
\text { uma cabine de fotos. }\end{array}$ & $\begin{array}{l}\text { Operar um elevador; } \\
\text { Usar uma escada } \\
\text { rolante. }\end{array}$ & $\begin{array}{l}\text { Provar um prato em um } \\
\text { jantar com bufê; Colocar } \\
\text { as compras do } \\
\text { supermercado em } \\
\text { sacolas. }\end{array}$ & $\begin{array}{l}\text { Documentar o histórico } \\
\text { médico em uma clínica; } \\
\text { Buscar informações em } \\
\text { uma biblioteca. }\end{array}$ & $\begin{array}{l}\text { Dirigir um carro alugado; } \\
\text { Usar as instalações de } \\
\text { uma academia. }\end{array}$ \\
\hline & $\begin{array}{l}\text { Há interação } \\
\text { entre o prestador } \\
\text { e o cliente. }\end{array}$ & $\begin{array}{l}\text { Servir alimentos em um } \\
\text { restaurante; Lavar } \\
\text { carros. }\end{array}$ & $\begin{array}{l}\text { Dar uma palestra; } \\
\text { Fazer transações } \\
\text { rotineiras de uma } \\
\text { agência bancária. }\end{array}$ & $\begin{array}{l}\text { Fornecer transporte } \\
\text { público; Fornecer } \\
\text { vacinação em massa. }\end{array}$ & $\begin{array}{l}\text { Limpar o carpete de } \\
\text { casa; Realizar serviço de } \\
\text { jardinagem. }\end{array}$ & $\begin{array}{l}\text { Pintar um retrato; } \\
\text { Conduzir uma } \\
\text { psicoterapia. }\end{array}$ & $\begin{array}{l}\text { Cortar o cabelo; Realizar } \\
\text { uma cirurgia. }\end{array}$ \\
\hline
\end{tabular}

QUADRO 3.12 - Tipologia de serviços proposta por Wemmerlöv (1990)

Fonte : Baseado na Figura 1 de Wemmerlöv (1990)

Apoiando-se nesta taxonomia, Wemmerlöv (1990) descreve os principais aspectos a serem considerados no projeto do processo e nos sistemas de operação de serviço, face às diferentes combinações das variáveis envolvidas (Quadro 3.13). 


\begin{tabular}{|c|c|c|}
\hline $\begin{array}{l}\text { Grau de contato } \\
\text { com o cliente }\end{array}$ & PROCESSOS RÍGIDOS & PROCESSOS FLUIDOS \\
\hline \multirow{11}{*}{$\begin{array}{l}\text { Nenhum contato } \\
\text { ou contato } \\
\text { indireto com o } \\
\text { cliente }\end{array}$} & Instalações não necessitam estarem próximas do Mercado. & Instalações não necessitam estarem próximas do Mercado. \\
\hline & $\begin{array}{l}\text { Layout, Projeto de Processo, sistema de manuseio de materiais e } \\
\text { processamento de informações desenvolvidos para lidar com } \\
\text { tarefas repetitivas e de alto volume. }\end{array}$ & $\begin{array}{l}\text { Layout, Projeto de Processo, sistema de manuseio de materiais e } \\
\text { processamento de informaçôes devem ser desenvolvidos para } \\
\text { trabalhar com uma maior flexibilidade em termos de tarefas e } \\
\text { volume. }\end{array}$ \\
\hline & Alto potencial para mecanização/automação. & Baixo potencial para mecanização/automação. \\
\hline & Tempos padrões confiáveis podem ser estimados. & Tempos padrões confiáveis não podem ser estimados. \\
\hline & $\begin{array}{l}\text { Alta utilização da capacidade através do balanceamento de } \\
\text { equipamentos e mão-de-obra do processo. }\end{array}$ & $\begin{array}{l}\text { Alta utilização da capacidade através de um sistema order } \\
\text { backlogging. }\end{array}$ \\
\hline & $\begin{array}{l}\text { O planejamento das atividades pode ser baseado em medidas de } \\
\text { performance existentes. }\end{array}$ & $\begin{array}{l}\text { O planejamento das atividades baseado tanto em considerações } \\
\text { relativas ao sistema quanto ao cliente. }\end{array}$ \\
\hline & $\begin{array}{l}\text { O controle da qualidade é atingido através do planejamento e } \\
\text { controle, manutenção dos equipamentos e qualidade dos bens. }\end{array}$ & $\begin{array}{l}\text { O controle da qualidade é atingido através do controle das } \\
\text { habilidades dos funcionários e da qualidade dos bens. }\end{array}$ \\
\hline & Efetiva gestão de inventário para assegurar fluxo de materiais. & $\begin{array}{l}\text { Gestão de inventário torna-se menos crucial, pois materiais } \\
\text { podem ser solicitados após tomada de pedido. }\end{array}$ \\
\hline & Baixa ou média habilidade técnica é requerida. & Média ou alta habilidade técnica é requerida. \\
\hline & Sistema de remuneração pode ser baseado nos outputs & Sistema de remuneração deve ser independente do output obtido. \\
\hline & $\begin{array}{l}\text { Pedidos e requisitos de capacidade podem ser previstos com } \\
\text { certa precisão. }\end{array}$ & $\begin{array}{l}\text { Chegada de pedidos é mais fácil de ser prevista do que } \\
\text { determinação do tipo de serviço que será realizado. }\end{array}$ \\
\hline \multirow{8}{*}{$\begin{array}{l}\text { Contato direto } \\
\text { com o cliente, } \\
\text { sem interação } \\
\text { com o } \\
\text { funcionário }\end{array}$} & Instalações necessitam estarem próximas do Mercado. & Instalações necessitam estarem próximas do Mercado. \\
\hline & $\begin{array}{l}\text { Layout e demais requisitos do processo devem ser acessíveis aos } \\
\text { usuários. }\end{array}$ & $\begin{array}{l}\text { Layout e demais requisitos do processo devem ser acessíveis aos } \\
\text { usuários. }\end{array}$ \\
\hline & Alto potencial para mecanização. & Baixo potencial para mecanização. \\
\hline & Tempos padrões confiáveis podem ser estimados. & Tempos padrões confiáveis difíceis de serem estimados. \\
\hline & Sistemas de reservas possibilitam suavizar os picos de demanda. & Alta utilização conseguida através de filas. \\
\hline & Planejamento das atividades baseado na chegada dos clientes. & Planejamento das atividades baseado no PEPS. \\
\hline & $\begin{array}{l}\text { O controle da qualidade é atingido através do planejamento e } \\
\text { controle, manutenção dos equipamentos e qualidade dos bens. }\end{array}$ & $\begin{array}{l}\text { O controle da qualidade é atingido através da manutenção dos } \\
\text { equipamentos e qualidade dos bens. }\end{array}$ \\
\hline & $\begin{array}{l}\text { Efetiva gestão de inventário para evitar falta de materiais que } \\
\text { implica em perda de vendas. }\end{array}$ & $\begin{array}{l}\text { Efetiva gestão de inventário para evitar falta de materiais que } \\
\text { implica em perda de vendas. }\end{array}$ \\
\hline \multirow{13}{*}{$\begin{array}{l}\text { Contato direto } \\
\text { com o cliente, } \\
\text { com interação } \\
\text { com o } \\
\text { funcionário }\end{array}$} & $\begin{array}{l}\text { Instalações necessitam estarem próximas do mercado, a menos } \\
\text { que o processo de serviço vá até o cliente. }\end{array}$ & $\begin{array}{l}\text { Instalações necessitam estarem próximas do mercado, a menos } \\
\text { que o processo de serviço vá até o cliente. }\end{array}$ \\
\hline & Layout deve ser atrativo para os clientes quanto eficiente. & $\begin{array}{l}\text { Layout deve ser atrativo para os clientes e projetado para ser } \\
\text { flexível. }\end{array}$ \\
\hline & $\begin{array}{l}\text { Os processos de serviço, manuseio de materiais e processamento } \\
\text { de informações devem ser planejados para lidar com tarefas } \\
\text { repetitivas e alto volume. }\end{array}$ & $\begin{array}{l}\text { Os processos de serviço, manuseio de materiais e processamento } \\
\text { de informações não devem ser rígidos e devem ser capazes de } \\
\text { lidar com diferentes volumes e dificuldades das tarefas. }\end{array}$ \\
\hline & Alto potencial para mecanização/automação. & $\begin{array}{l}\text { Alto potencial para mecanização/automação de alguns processos } \\
\text { selecionados. }\end{array}$ \\
\hline & $\begin{array}{l}\text { Tempos padrões confiáveis podem ser estimados, desvios } \\
\text { devidos ao comportamento do cliente devem ser planejados. }\end{array}$ & $\begin{array}{l}\text { Tempos padrões difíceis de serem estimados e não compensam } \\
\text { serem estimados devido ao esforço que seria necessário frente à } \\
\text { variedade de tarefas existentes. }\end{array}$ \\
\hline & $\begin{array}{l}\text { Sistemas de reservas e incentivos de preço possibilitam suavizar } \\
\text { os picos de demanda. }\end{array}$ & \multirow{2}{*}{$\begin{array}{l}\text { Sistemas de reservas e incentivos de preço possibilitam suavizar } \\
\text { os picos de demanda. }\end{array}$} \\
\hline & $\begin{array}{l}\text { Programação da utilização da mão-de-obra é importante para } \\
\text { evitar filas ou perda de vendas. }\end{array}$ & \\
\hline & $\begin{array}{l}\text { Seqüênciamento dos pedidos baseado em regras de prioridade } \\
\text { ditadas pelo sistema. }\end{array}$ & $\begin{array}{l}\text { Seqüênciamento dos pedidos baseado em regras de prioridade } \\
\text { ditadas pelo sistema. }\end{array}$ \\
\hline & $\begin{array}{l}\text { O controle da qualidade é atingido através do planejamento e } \\
\text { controle, manutenção dos equipamentos, qualidade dos bens e } \\
\text { procedimentos padronizados. }\end{array}$ & $\begin{array}{l}\text { O controle da qualidade é atingido através da manutenção dos } \\
\text { equipamentos, qualidade dos bens e controle de habilidades e } \\
\text { atitudes dos funcionários. }\end{array}$ \\
\hline & $\begin{array}{l}\text { Efetiva gestão de inventário para evitar falta de materiais que } \\
\text { implicam em perda de vendas. }\end{array}$ & $\begin{array}{l}\text { Material dever ser back-ordered de modo antecipado para reduzir } \\
\text { o risco e custo do inventário }\end{array}$ \\
\hline & Baixa ou média habilidade técnica é requerida. & Média ou alta habilidade técnica é requerida. \\
\hline & $\begin{array}{l}\text { Sistema de remuneração pode ser parcialmente baseado no } \\
\text { cumprimento do papel de vendas por parte do funcionário. }\end{array}$ & $\begin{array}{l}\text { Sistema de remuneração pode ser parcialmente baseado no } \\
\text { cumprimento do papel de vendas por parte do funcionário. }\end{array}$ \\
\hline & $\begin{array}{l}\text { Necessidades de recursos podem ser estabelecidas através de } \\
\text { previsões de demanda, taxas de chegada de clientes e taxas de } \\
\text { uso de material. }\end{array}$ & $\begin{array}{l}\text { Necessidades de recursos difíceis de serem previstas devido à } \\
\text { alta variabilidade dos pedidos. }\end{array}$ \\
\hline
\end{tabular}

QUADRO 3.13 - Prescrições segundo as características de processo

Fonte : Baseado na Tabela 2 de Wemmerlöv (1990)

Silvestro; Fitzgerald e Johnston (1992), como forma de unificar as diferentes dimensões de classificação sem, entretanto, causar distorções às variáveis até então utilizadas, propuseram uma nova tipologia de classificação. Essa tipologia foi concebida considerando seis variáveis:

- Foco nos equipamentos ou nas pessoas: O foco nos equipamentos se dá quando estes são os elementos centrais para a entrega de serviço. Já o 
foco nas pessoas ocorre quando a provisão de pessoal de contato é o elemento central para a entrega de serviço.

- Tempo de contato com o cliente por transação: O contato do cliente é considerado alto se ele gasta horas, dias ou semanas no sistema de serviço, por transação. Pode também ser considerado baixo se realizado em alguns minutos apenas.

- Grau de customização: O grau de customização é alto quando o processo de serviço se adapta às necessidades individuais dos clientes. O grau de customização é baixo quando existe um processo padronizado não-variado e a disponibilidade de opções é predeterminada.

- Grau de discrição: O grau de discrição é alto quando o pessoal da linha de frente pode exercer julgamento para alterar o pacote de serviço ou processo sem consultar seus superiores. O grau de discrição é baixo quando as mudanças para o fornecimento do serviço podem ser feitas apenas com autorização de superiores.

- Orientação para o back-office (retaguarda) ou front-office (linha de frente): Um processo de serviço com orientação ao back-office caracteriza-se por uma proporção maior de funcionários nesta posição. Observa-se a mesma lógica de alocação de recursos em processos orientados para o front-office.

- Foco em produtos ou processos: Um serviço com foco em produtos é caracterizado pela ênfase ao objeto de compra do cliente. Já um serviço com foco em processos destaca o modo como o serviço é entregue ao cliente.

À luz dessas características e baseando-se no volume de processamento de pessoas da operação, estes autores definiram três tipos básicos de operações de serviço:

- Serviços profissionais: serviços com volume de transações relativamente baixo, alto grau de personalização, orientação para o processo, tempo de contato relativamente alto, mais valor agregado nas atividades de linha de frente e funcionários da linha de frente com alto grau de discrição. 
- Lojas de serviços: serviços que se enquadram nessa categoria costumam ter níveis intermediários no que diz respeito às características citadas. Têm um tempo de contato médio com clientes e nível médio de customização e discrição. O recurso principal pode estar voltado tanto para pessoas como para equipamentos, orientação de sua estrutura direcionada para o front-office ou back-office. Já o volume de processamento/dia por funcionário oscila entre os valores extremos que caracterizam os serviços de massa e os serviços profissionais.

- Serviços de massa: serviços em que o volume de transações com clientes é alto, envolvendo limitado tempo de contato e pouca personalização. As ofertas são predominantemente orientadas para o produto e o valor agregado é maior nas atividades de retaguarda. Os funcionários de linha de frente têm baixo grau de discrição.

A Figura 3.8 ilustra esta classificação, posicionando os três tipos básicos em função do volume de processamento de clientes e demais dimensões consideradas (SILVESTRO; FITZGERALD e JOHNSTON , 1992).

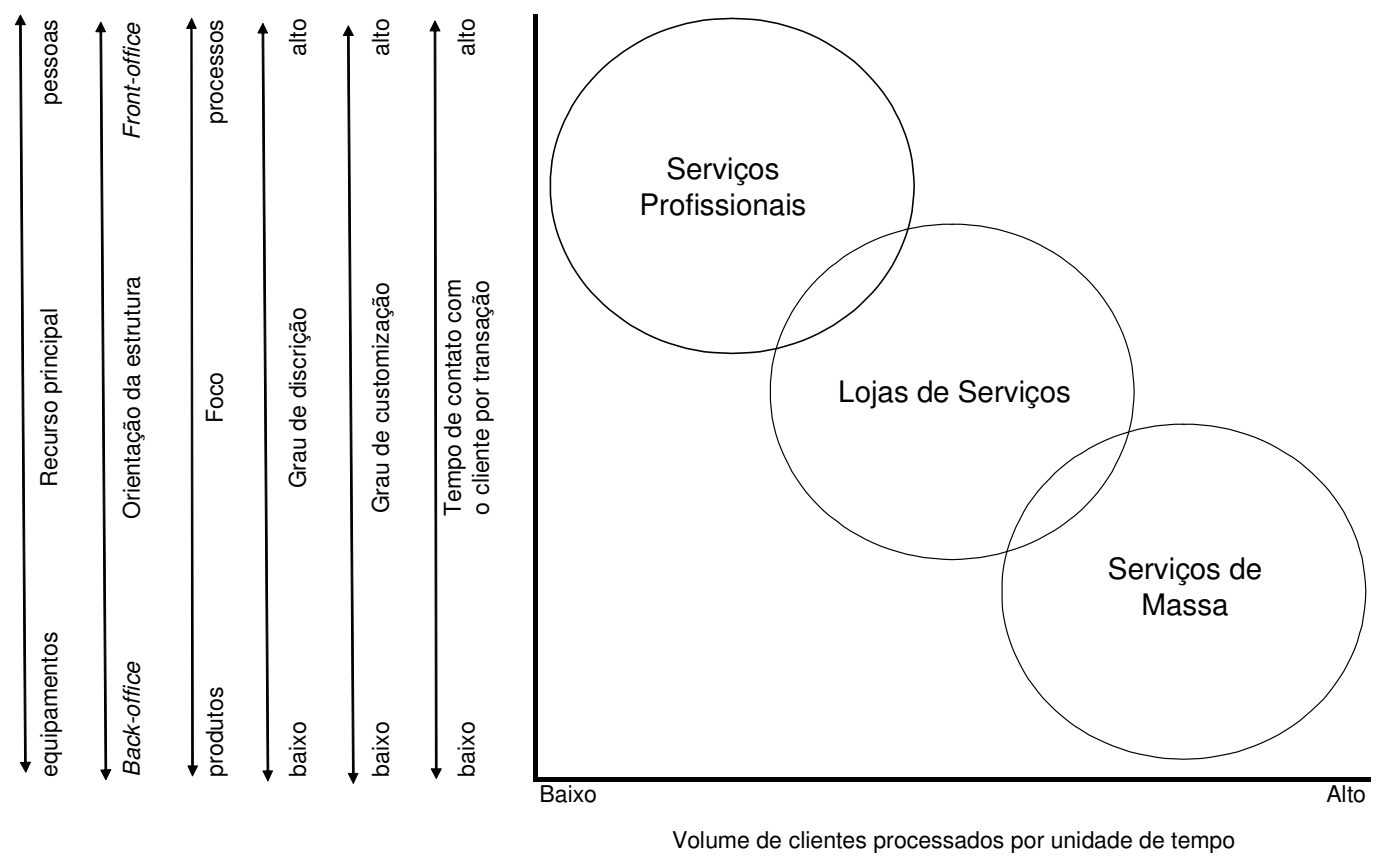

FIGURA 3.8 - Tipos de processo de serviço

Fonte : Baseada na Figura 6 de Silvestro; Fitzgerald e Johnston (1992) 
Johnston e Clark (2002), baseando-se no trabalho de Silvestro; Fitzgerald e Johnston (1992), subdividem a categoria loja de serviços em duas: lojas de serviços profissionais e lojas de serviços de massa. A Figura 3.9 ilustra essa nova classificação proposta por estes autores.

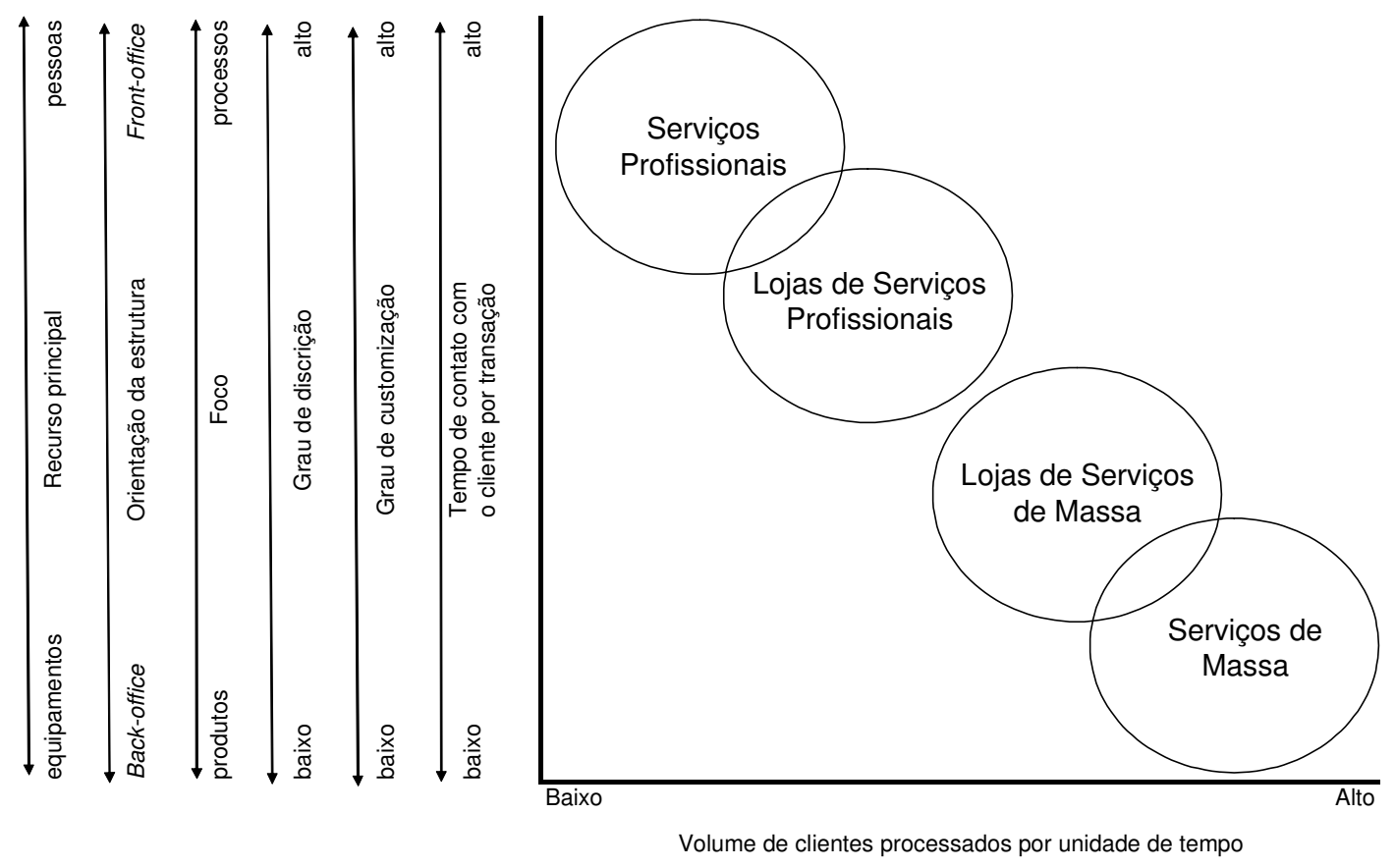

FIGURA 3.9 - Tipos de processo de serviço em função do volume e variedade Fonte : Adaptada da Figura 1.5 de Johnston e Clark (2002)

De modo semelhante a Johnston e Clark (2002), Corrêa e Caon (2002) e Corrêa e Corrêa (2004) tomaram como base o trabalho de Silvestro; Fitzgerald e Johnston (1992) e acrescentaram duas novas categorias de serviços à classificação destes: Serviços Profissionais de Massa e Serviços de Massa Customizados. Na visão Corrêa e Caon (2002) e Corrêa e Corrêa (2004), entre os serviços profissionais e serviços de massa há, literalmente, infinitas posições. Portanto, eles argumentam que, para fins didáticos, vale a pena inserir três estágios intermediários:

- Serviços de massa customizados: estão numa posição de volume próxima a dos serviços de massa, mas ao fazerem uso de tecnologias, principalmente as mais avançadas tecnologias de informação, proporcionam, de forma 
automatizada, uma sensação de serviço customizado ao cliente. Neste serviço quase tudo é feito de modo automatizado, possibilitando que um volume bastante alto de transações com clientes seja atendido por dia, criando-se neles a sensação que estão sendo tratados de forma personalizada.

- Serviços profissionais de massa: posicionam-se próximos à região de serviços profissionais, mas buscam atender um número maior de clientes.

- Lojas de serviços: A maioria das operações de serviços se situa nesta faixa atendendo um volume de clientes maior que serviços profissionais e serviços profissionais de massa, mas menores que serviços de massa customizados e serviços de massa. Neste posicionamento, os serviços são caracterizados por apresentarem uma situação intermediária em relação às seis variáveis utilizadas nesta tipologia (principal tipo de recurso: equipamentos/pessoas, tempo de contato com o cliente por transação, grau de customização, grau de discrição, orientação da estrutura para o back-office ou front-office e foco nos produtos ou processos). A Figura 3.10 ilustra esta classificação.

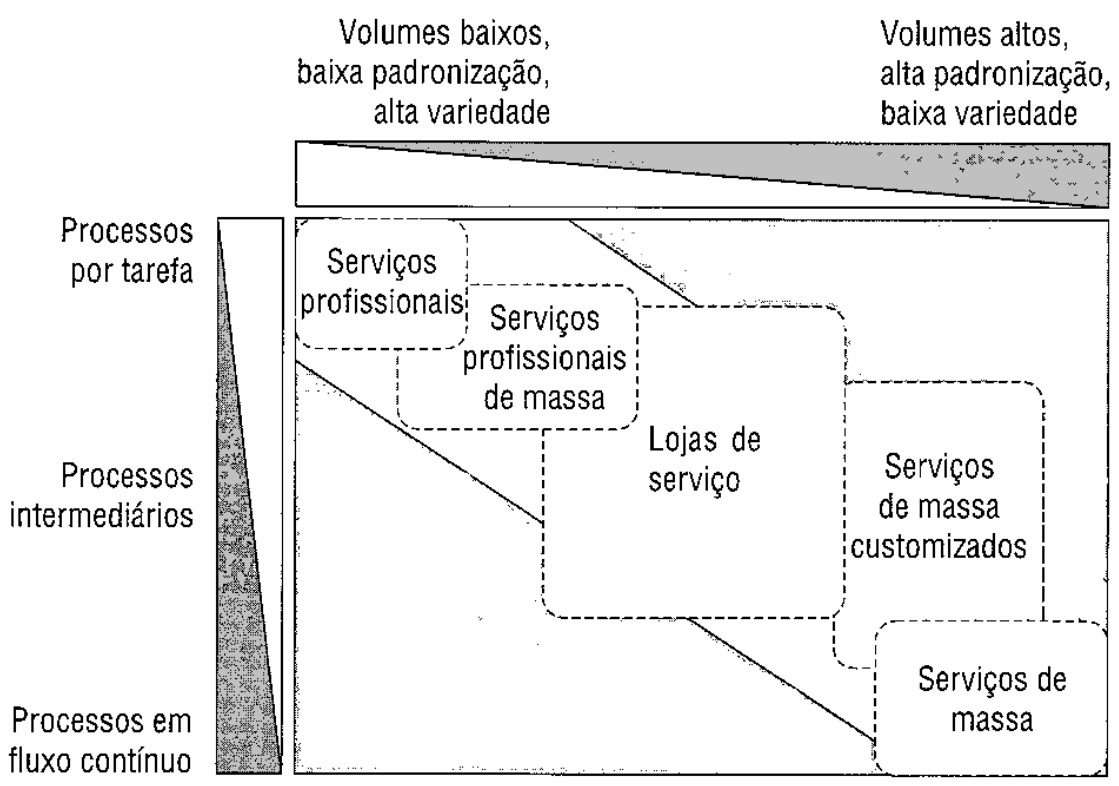

FIGURA 3.10 - Matriz produto-processo em operações de serviço Fonte : Baseada na figura 10.12 de Corrêa e Corrêa (2004) 


\subsubsection{Considerações do autor}

Foram apresentadas diversas formas para classificar os serviços, propostas por diversos pesquisadores, mas apenas duas classificações foram utilizadas no presente estudo. No primeiro capítulo, para fins de definição do objeto de estudo, foram utilizadas a classificação pela natureza do ato do serviço proposta por Lovelock (1983) e a classificação volume-variedade proposta por Silvestro; Fitzgerald e Johnston (1992).

Uma terceira classificação foi utilizada na delimitação do objeto de estudo. Ela distingue se há predominância de produtos diretos ou de seus resultados ulteriores num intervalo continuum entre os dois extremos. Vale ressaltar que esta forma de classificação não foi ainda contemplada pela literatura estudada, o que indica ser uma perspectiva original para o tratamento de processos de serviços.

Levando em consideração o trabalho de Cook; Goh e Chung (1999), pode-se admitir que estas três classificações revelam uma visão mais micro, sendo orientadas tanto para as operações (classificação utilizada de Silvestro; Fitzgerald e Johnston (1992) que considera várias dimensões em função do volume de processamento de clientes - Figura 3.8), como para o mercado (classificação de Lovelock (1983) que distingue os serviços pela natureza do ato do serviço e seu beneficiário direto - Figura 3.1 e classificação que distingue a natureza do impacto do serviço pela predominância de produtos diretos ou predominância de seus resultados ulteriores - Figura 1.5).

\subsection{CARACTERÍSTICAS DOS SERVIÇOS DE RESULTADOS ULTERIORES POR MEIO DOS DIFERENTES PAPÉIS DO CLIENTE}

Como esboçado no capítulo de Introdução, em SRUs, os resultados ulteriores buscados pelo serviço dependem da participação e do empenho dos clientes nas atividades realizadas durante a entrega do serviço. É preciso considerar 
ainda que os serviços considerados neste trabalho restringem-se aos que processam pessoas e isso torna necessário entender quais são os papéis que o cliente pode assumir. No estudo de Lengnick-Hall (1996), tais papéis são analisados numa organização qualquer ${ }^{7}$, sendo identificados cinco tipos básicos: cliente como recurso, cliente como co-produtor, cliente como comprador, cliente como usuário e cliente como um produto. A Figura 3.11 ilustra estes papéis sob a ótica de um processo de transformação.

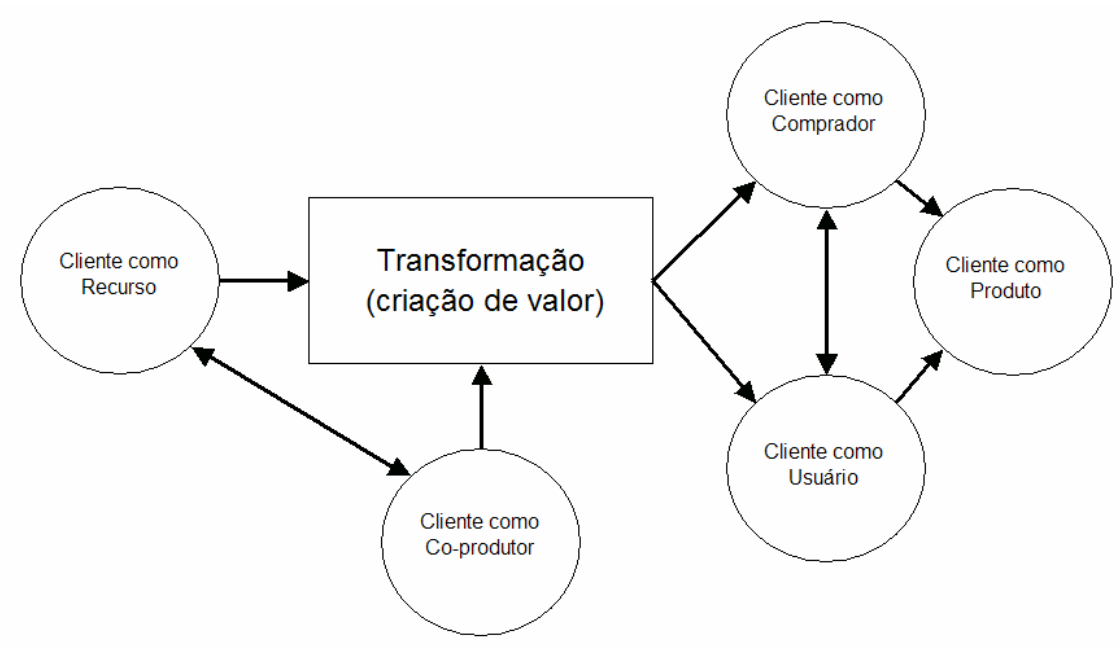

FIGURA 3.11 - Os possíveis papéis do cliente

Fonte: Figura 1 de Lengnick-Hall (1996)

Os SRUs analisados na tese serão melhor compreendidos à luz dos papéis propostos por Lengnick-Hall (1996). Cada um deles é descrito nas seções seguintes.

\footnotetext{
${ }^{7}$ A autora discute estes papéis para qualquer organização, seja um fabricante de bens ou uma empresa de serviços.
} 


\subsubsection{Cliente como recurso}

O cliente pode fornecer diferentes fatores de produção, por exemplo: informação, dinheiro, idéias, material a ser processado. Em alguns serviços, além de tais fatores, o próprio cliente pode passar por uma transformação (LENGNICKHALL, 1996). Nos SRUs que são objeto de estudo, o cliente é a matéria-prima principal para o processo de transformação.

Algumas diretrizes normalmente utilizadas para administrar os recursos materiais de entrada, em processos industriais, podem ser estendidas aos SRUs que processam pessoas. Primeiro, os recursos (os clientes) podem ser deliberadamente escolhidos, quando possível ${ }^{8}$. Esta prática deve ser baseada na habilidade do cliente em adicionar valor ao processo. Neste ponto, pode ser feita uma analogia com os processos industriais, em que o desenvolvimento dos fornecedores e a seleção correta da matéria-prima levam a um melhor desempenho das operações (JURAN, 1990; DEMING, 1990). A própria prática de segmentação de mercado, buscando clientes com características compatíveis (horário, preferências, perfil socioeconômico, etc.) pode ser vista como uma prática indireta de seleção de clientes. As informações provenientes dos clientes são importantes para o planejamento do serviço. Informações incompletas ou erradas podem levar a atrasos, retrabalhos ou mesmo a falhas na execução do serviço pretendido. Portanto, a empresa deve buscar meios para que todas as informações necessárias sejam coletadas e estejam corretas. Para isso, ela poderá optar por realizar internamente exames/medições que possam ser realizadas por terceiros ou exigir as informações necessárias como um pré-requisito para iniciar a entrega do serviço. Pode ainda informar e educar o cliente quanto à importância e ao tipo de informações que são necessárias para se iniciar o processo de entrega do serviço. A empresa poderá fazer um diagnóstico do cliente identificando sua real situação para definição das atividades que deverão ser realizadas a fim de atingir os resultados ulteriores desejados. Mais uma vez, vale aqui a analogia com os processos

\footnotetext{
${ }^{8}$ Em vários tipos de serviços, esta prática pode ser restringida.
} 
industriais, em que a inspeção de entrada da matéria-prima é uma prática corrente para se definir melhor as ações de processo que deverão ser tomadas (JURAN, 1990; DEMING, 1990).

\subsubsection{Cliente como co-produtor}

O cliente pode assumir a execução de várias atividades do processo de entrega do serviço no lugar dos funcionários. Neste papel, o cliente é mobilizado como um recurso produtivo, ou seja, como um "funcionário parcial" (BOWEN, 1986; MILLS e MORRIS, 1986; WIKSTRÖM, 1996; ZEITHAML e BITNER, 2003).

A sua participação pode afetar positivamente a produtividade da organização. Isso pode ocorrer sem um detrimento maior da qualidade percebida pelo serviço (LOVELOCK e YOUNG, 1979). Porém, a participação do cliente no processo nem sempre é bem vista pela literatura. Os defensores da abordagem da linha de produção argumentam que o sistema de prestação de serviços deveria ser isolado ao máximo dos clientes, a fim de reduzir a incerteza que eles podem introduzir no processo produtivo, haja vista a influência que teriam no cumprimento dos prazos e a dificuldade de controlar suas atitudes e ações (LEVITT,1972; CHASE, 1978).

Para que a participação do cliente seja bem-sucedida, Bowen (1986) realça a importância de orientá-lo e treiná-lo adequadamente para a execução das suas tarefas, assegurando que seja capaz de executá-las. Nesse sentido, a empresa pode fornecer antecipações realistas sobre o serviço, como um meio de tornar os clientes cientes de seus papéis de co-produção. Isso implica também na empresa definir de forma consistente e clara quais as tarefas e como elas deverão ser realizadas pelo cliente.

A empresa pode também envolver o cliente no planejamento das atividades do serviço que será oferecido, solicitando suas idéias e sugestões para a definição das atividades que compõem o processo de serviço (WIKSTRÖM, 1996). 
Ela pode inclusive premiar ou recompensar a participação do cliente. Vários incentivos podem ser identificados quando este participa como co-produtor:

- preços mais baixos, uma vez que a empresa pode obter redução de custo com o aumento de produtividade;

- a auto-estima é elevada por causa do aumento de controle por parte do cliente;

- o próprio cliente passa a ter mais discrição e oportunidades para fazer escolhas;

- os tempos de espera podem ser reduzidos;

- possibilita mais personalização do serviço (LENGNICK-HALL,1996).

\subsubsection{Cliente como comprador}

Neste papel, o cliente define a aquisição do serviço. As empresas precisam se empenhar para converter clientes potenciais em clientes reais. A decisão de compra é um objeto de estudo da área de marketing. Atributos como análise, experiência e credibilidade levam os clientes a decidirem pelo serviço $A$ ou $B$ (HOFFMAN e BATESON, 2003).

A literatura de marketing de serviços tem enfatizado a importância do estabelecimento, por parte da empresa, de um relacionamento duradouro com o seu público, para que consiga retê-los (GRÖNROOS, 2003; GUMMESSON, 2005). Lovelock e Wright (2002) observam que são vários os ganhos advindos da retenção dos clientes. Quanto mais um cliente permanece com uma empresa, mais lucrativo é servi-lo. Além disso, os custos iniciais para atrair clientes fiéis podem ser amortizados no decorrer de um período mais longo que pode se estender a muitos anos. Há quatro fatores que trabalham a favor do fornecedor de serviços na obtenção de lucros crescentes por meio da fidelização do cliente: i) lucro derivado do aumento das compras; ii) lucro por redução de custos operacionais; iii) lucro por indicações de outros clientes; e iv) lucro por preço superior. Os benefícios 
econômicos da lealdade de seus clientes freqüentemente explicam por que uma empresa é mais lucrativa do que uma concorrente.

Heskett; Sasser Jr. e Schlesinger (2002) relatam que a relação entre satisfação e fidelidade não ocorre da mesma maneira de um setor para o outro. De um modo geral, a fidelidade é obtida quando se trabalha com altos níveis de satisfação. A Figura 3.12 retrata esta situação, colocando o cliente completamente satisfeito como um "apóstolo", ou seja, além de fiel, ainda recomenda o serviço a terceiros. Já aquele muito insatisfeito age como um "terrorista" para a empresa, na medida em que expressa uma extrema insatisfação para os outros, fazendo uma publicidade negativa.

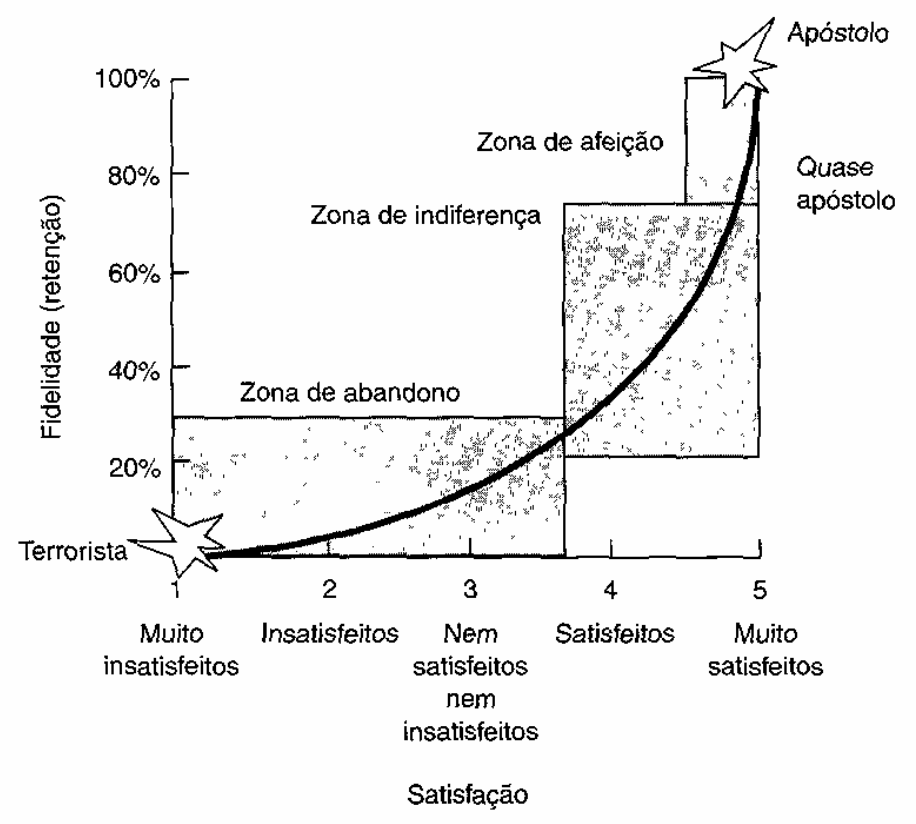

FIGURA 3.12 - Curva de Satisfação-Fidelidade

Fonte: Figura 5.4 de Heskett; Sasser Jr. e Schlesinger (2002)

Ambas as partes da relação cliente/empresa podem beneficiar-se da retenção de clientes. Ou seja, a construção e a manutenção de uma base de clientes leais não podem ser vista apenas como um objetivo exclusivo da organização. Os 
próprios clientes são também beneficiados pelo estabelecimento de uma relação de longo prazo com uma empresa. Quanto mais valor os clientes receberem, mais leais eles se tornam. O valor é percebido pelos clientes por meio de uma análise geral feita por cada cliente sobre a utilidade de um serviço com base nas suas percepções sobre o que é recebido e o que é fornecido. Na acepção dos autores Gwinner; Gremier e Bitner (1998), além dos benefícios específicos inerentes ao recebimento do valor do serviço em si, os clientes também se beneficiam de outras formas. $\mathrm{Na}$ visão destes autores há quatro tipos de benefícios que podem favorecer o cliente num relacionamento de longo prazo, são eles:

- Benefícios psicológicos: os clientes percebem um menor risco de algo dar errado no serviço, pois desenvolveram maior confiança no desempenho do provedor de serviço. Isto leva a uma redução dos sentimentos de ansiedade e a um aumento da percepção de conforto, decorrente do fato de o que cliente consegue mais facilmente saber 0 que esperar do serviço;

- Benefícios sociais: com o tempo, os clientes desenvolvem um senso de familiaridade e até mesmo um relacionamento social com funcionários do prestador de serviços. Essas ligações tornam menos provável que os clientes mudem de fornecedor. Em alguns relacionamentos de longo prazo, um funcionário pode, efetivamente, tornar-se parte de um sistema de apoio social ao cliente, sendo, por exemplo, visto como um amigo, conselheiro ou confidente do cliente;

- Benefícios econômicos: eles incluem melhores preços, descontos em negociações especiais que normalmente não estão disponíveis para a maioria dos outros clientes, prioridade no atendimento e serviços mais rápidos do que o recebido por outros clientes, entre outras vantagens;

- Benefícios de customização: eles incluem ações que visam adaptar os serviços às necessidades específicas dos clientes. Isto pode ser efetuado por meio de um tratamento preferencial, ou através da oferta de serviços extras, ou mesmo pelo conhecimento das preferências e do próprio histórico do cliente o que possibilita uma maior conveniência ao mesmo. 
Berry e Parasuraman (1995) notam que o relacionamento pode ser praticado em diferentes níveis, dependendo do tipo e do número de elos que uma empresa utiliza para promover a lealdade do cliente. Quanto mais elevado o nível de relacionamento praticado, mais elevado é o potencial de recompensa. No nível um do relacionamento, o mais incipiente, a empresa utiliza apenas os incentivos de preço para estimular os clientes a fazerem mais negócios e assim estabelecer elos ditos financeiros. No nível dois, além de utilizar incentivos de preços, a empresa procura formar elos sociais com seu público enfatizando a prestação de serviços mais personalizados. A empresa dá mais ênfase ao contato com o cliente, ao conhecimento de suas necessidades e desejos, portanto, procura a personalização por meio de um nível de relacionamento mais elevado. No nível três, ela consolida os relacionamentos com clientes por meio de elos ditos estruturais, além dos elos sociais e financeiros. Os elos estruturais são criados por meio de serviços valiosos (no sentido que ajudam os clientes a se tornarem mais eficientes ou produtivos). Serviços nesse nível ainda não estão disseminados no mercado. Como é difícil imitar os concorrentes que já atingiram tal nível, estes se fortalecem pelo seu alto grau de retenção dos clientes.

\subsubsection{Cliente como usuário}

Neste papel, o cliente recebe diretamente o serviço e se beneficia dele. Como usuário, pode criar dois resultados importantes. Primeiro, mede a discrepância entre suas expectativas e a experiência de serviço recebida, determinando, desse modo, sua satisfação (ZEITHAML e BITNER, 2003). Segundo, os clientes desenvolvem relações com o provedor de serviços. No caso de um SRU, também realizam as atividades prescritas pelo provedor. 
Como destacado no capítulo de Introdução, em SRUs, os resultados ulteriores buscados pelo serviço dependem dos clientes participarem e se empenharem nas atividades realizadas durante a entrega.

Vale novamente comentar que os SRUs não se limitam a um único episódio ou encontro de serviço. Dependem de vários encontros para que os resultados almejados sejam alcançados. Isso evidencia a necessidade do estabelecimento de um relacionamento entre o provedor de serviço e o cliente, devido à interdependência entre os diferentes encontros de serviços e, por conseqüência, a necessidade de continuidade entre tais eventos. Esse relacionamento deve ser monitorado de modo a identificar a necessidade de efetuar ajustes, caso os resultados ulteriores intermediários necessitem ser melhorados para que o resultado ulterior almejado possa ser alcançado. Portanto, o provedor de serviços deve estabelecer um sistema de monitoramento no relacionamento entre ambas as partes, capaz de realizar ajustes e correções no seu processo de entrega.

A fim de esclarecer melhor como um sistema de monitoramento pode ser estabelecido, algumas definições precisam ser colocadas.

O relacionamento da empresa com o cliente se dá mediante várias interações:

- interações entre funcionários e clientes;

- interações com vários recursos físicos e técnicos da organização;

- interações com sistemas como o de espera, sites de Internet, sistemas de telecomunicação, sistemas de entrega, etc.

- interações com outros clientes simultaneamente envolvidos no processo (GRÖNROOS, 2003).

As interações entre os clientes e a empresa podem ocorrer de três formas:

- Por contatos remotos: não existe contato humano direto, as interações podem ser realizadas apenas com os recursos físicos e técnicos da organização;

- Por contatos pessoais indiretos: consiste apenas na interação verbal, feita por telefone, entre os funcionários da empresa e o cliente; 
- Por contatos face a face: existe contato humano direto com os funcionários e com os recursos físicos e técnicos da organização (SHOSTACK, 1985).

Em termos de qualidade, cada uma dessas interações contempla duas dimensões: uma técnica que consiste nos resultados (outputs), ou seja, o que o cliente recebe; e uma funcional que se refere ao processo em si, ou seja, como o cliente recebe o serviço (GRÖNROOS, 2003).

Todas essas interações podem ser descritas por uma hierarquia que capta as relações que podem ocorrer entre as duas partes em diferentes níveis. Esta hierarquia contempla quatro níveis, do mais elementar ao mais agregado:

- $1^{\circ}$ nível - Atos: são as menores unidades de análise no processo de interação. Como exemplos de atos, podem ser citados os telefonemas, solicitações de serviço e registros num hotel. Eles também são chamados de "momentos da verdade".

- $\quad 2^{\circ}$ nível - Episódios: são compostos de atos inter-relacionados. Formam uma pequena parte de um relacionamento, sendo também denominados "encontros de serviço". Cada episódio inclui uma série de atos, como a ida a uma agência bancária para sacar dinheiro ou o jantar no restaurante de um hotel durante o período de hospedagem.

- $3^{0}$ nível - Seqüências: são formadas por episódios inter-relacionados. Podem ser definidas em termos de um período de tempo, uma campanha ou projeto, ou a combinação destes. Uma seqüência pode conter todo tipo de interações relacionadas com um projeto particular e chega a durar um ano ou mais. Como exemplo, no contexto de um hotel, uma seqüência compreende tudo que ocorre durante a estadia de um cliente nesse estabelecimento. Pode haver sobreposição de seqüências, de modo que episódios pertencentes a uma seqüência possam também ser parte de uma outra.

\footnotetext{
${ }^{9}$ Termo popular pelo qual se faz uma analogia com uma metáfora das touradas, denominando o termo para a situação em que o prestador de serviço e o cliente se confrontam em uma "arena".
} 
- $4^{\circ}$ nível - Relacionamento: é o nível mais agregado de análise, sendo constituído de diversas seqüências. Seqüências podem seguir umas às outras diretamente. Podem ainda se sobrepor ou ocorrer após intervalos mais longos ou mais curtos, dependendo, por exemplo, do tipo de empresa e da natureza do serviço - contínua ou discreta (HOLMLUND 1997, HOLMLUND, 2004; HOLMLUND e STRANDVIK, 1999).

Os quatro níveis que formam a hierarquia das interações entre a empresa e os clientes estão ilustrados na Figura 3.13.

Obviamente, nem todas as interações existentes entre o cliente e a empresa podem ser registradas e identificadas. Uma maneira prática de esquematizar as interações que normalmente são realizadas e registradas é apresentada na Figura 3.14, organizando-as hierarquicamente em diferentes níveis conforme o esquema proposto por Holmlund (1997 e 2004).

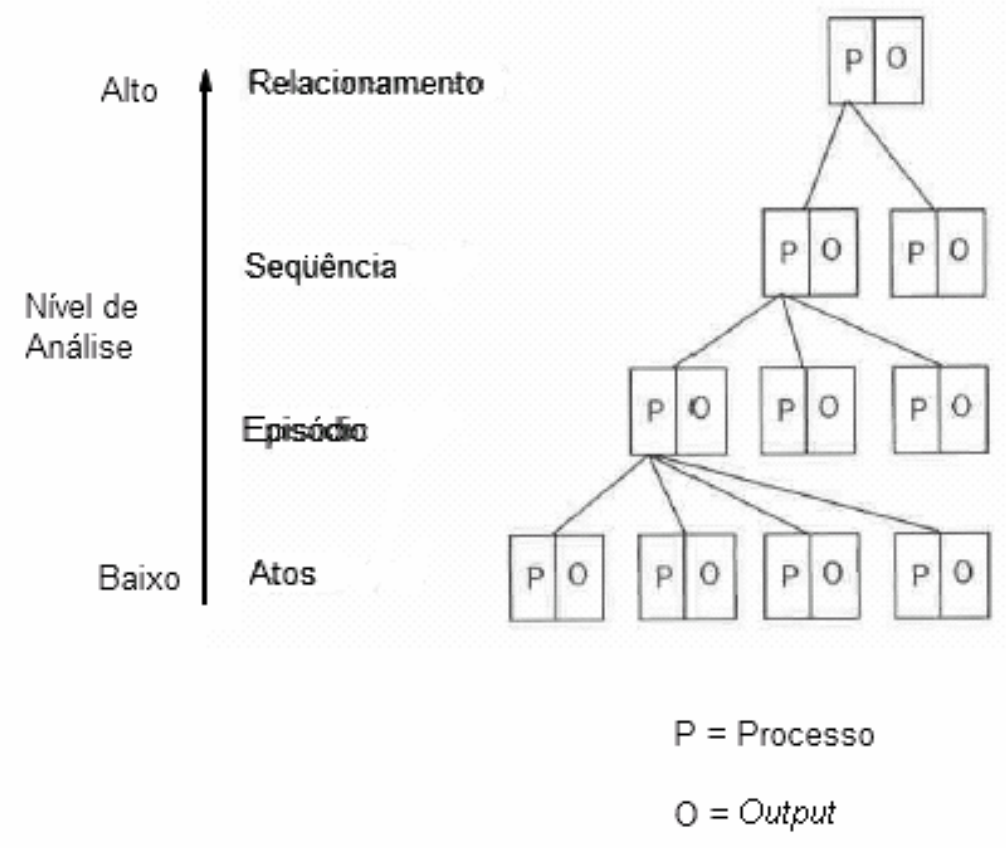

FIGURA 3.13 - Diferentes níveis de relações

Fonte: Baseada na Figura 1 de Holmlund e Strandvik (1999) 


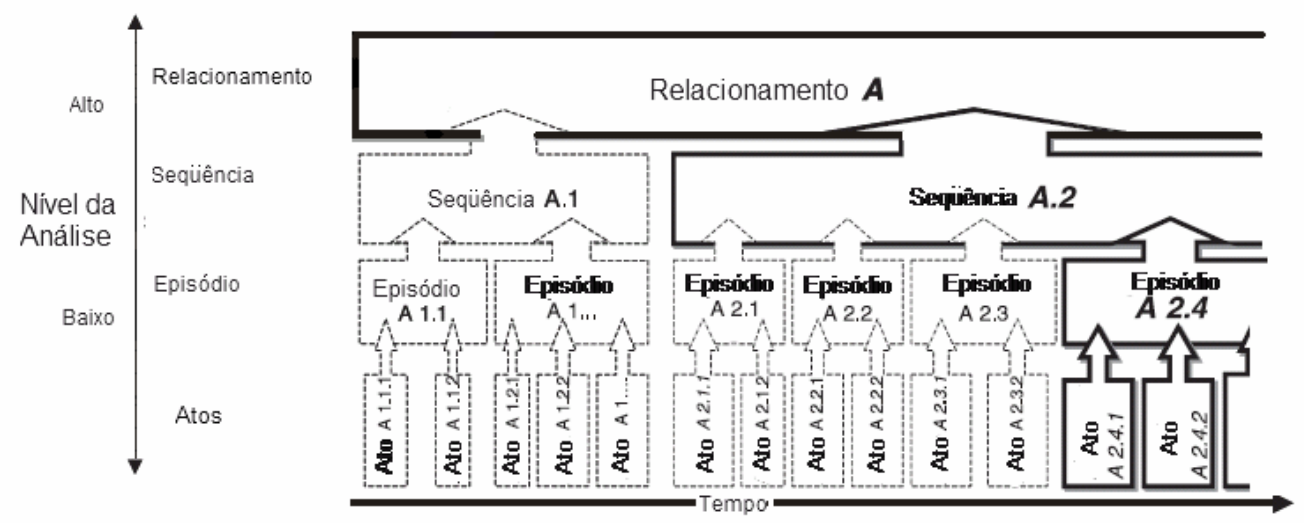

FIGURA 3.14 - Hierarquia das interações que formam o relacionamento da empresa com o cliente

Fonte: Adaptada da Figura 1 de Holmlund (2004)

Dada a estrutura hierárquica das interações, um sistema de monitoramento do relacionamento da empresa com os seus clientes deve ser capaz de acompanhar os principais episódios, identificando sua freqüência, a participação dos clientes nos serviços oferecidos e ajudando na avaliação dos resultados ulteriores desejados.

Baseando-se na Figura 3.14 proposta por Holmund (1997 e 2004) o autor do presente trabalho criou uma ferramenta gráfica a qual propõe denominar de "Mapa de Relacionamento". Por meio deste gráfico pode-se esquematizar o relacionamento da empresa com seus clientes e o seu monitoramento. Várias informações referentes ao sistema adotado pela empresa para monitorar seus clientes são retratadas no mesmo. Além das principais seqüências, episódios e atos que ocorrem entre a empresa e seus clientes, este mapa identifica os atos que são registrados e o tipo de registro que é utilizado. Um exemplo do Mapa de Relacionamento se encontra na Figura 3.15. Vale notar que não se verificou o uso aplicativo da Figura 3.14 nos trabalhos de Holmund (1997 e 2004) como uma ferramenta de descrição das interações que constituem um dado serviço. Esta figura foi apenas utilizada para esclarecer genericamente a hierarquia das interações existentes no relacionamento entre uma empresa e seus clientes. 


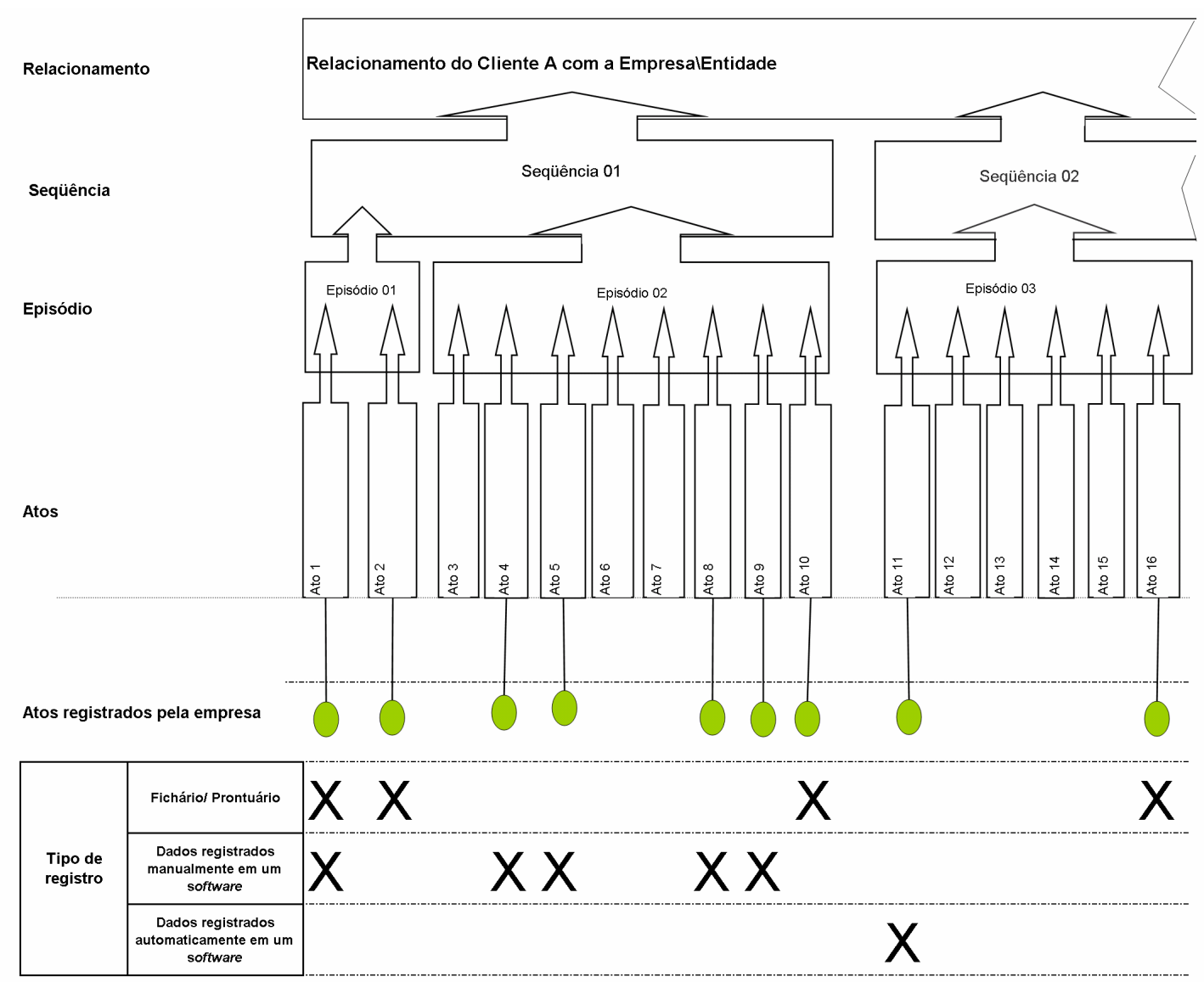

FIGURA 3.15 - Modelo de Mapa de Relacionamento

Fonte: Baseada da Figura 3.14

Convém aqui ressaltar que o gerenciamento de SRUs requer a formação de bancos de dados mais amplos do que os utilizados para o estabelecimento do chamado "Marketing de Relacionamento". Conforme coloca Winer (2001), o banco de dados no "Marketing de Relacionamento" deve conter basicamente quatro tipos de informação:

- Histórico das transações realizadas, com detalhes como preço pago, data de entrega, quantidade, etc;

- Canais de contato com o cliente disponíveis;

- Informação descritiva sobre o perfil do cliente;

- Nível de resposta do cliente a iniciativas de marketing direto pelo e-mail, telefone, contato durante a venda, etc. 
Como se vê, os quatro tipos de informação preconizados por Winer (2001) não abrangem todas as informações que são necessárias para o efetivo monitoramento do relacionamento entre as partes em SRUs. Conforme apontado anteriormente, o sistema de monitoramento em SRUs deve ser capaz de identificar a necessidade de efetuar ajustes, caso os resultados ulteriores intermediários necessitem ser melhorados para que o resultado ulterior almejado possa ser alcançado.

\subsubsection{Influência de fatores externos nos resultados ulteriores}

A obtenção dos resultados ulteriores desejados não depende apenas dos clientes participarem e se empenharem nas atividades realizadas durante a entrega do serviço. Fatores externos podem afetar a conquista destes resultados.

Como observou Pfeiffer (2000 e 2005), projetos (serviços) que visam produzir mudanças em pessoas ou organizações, normalmente, esbarram numa série de barreiras e riscos que dificilmente podem ser detectados ou antecipados na sua totalidade, mas um bom planejamento pode atenuar consideravelmente o efeito dos fatores externos considerados previamente. Mesmo assim, ainda existirão alguns fatores importantes para o seu êxito que estão fora do controle da gerência. A influência de tais fatores deve ser avaliada cuidadosamente e monitorada ao longo do tempo.

Os resultados ulteriores comportam-se de modos distintos segundo a unidade de análise e/ou escopo considerados. Alguns exemplos de unidades de análise são apresentados no item a) da Figura 3.16. 


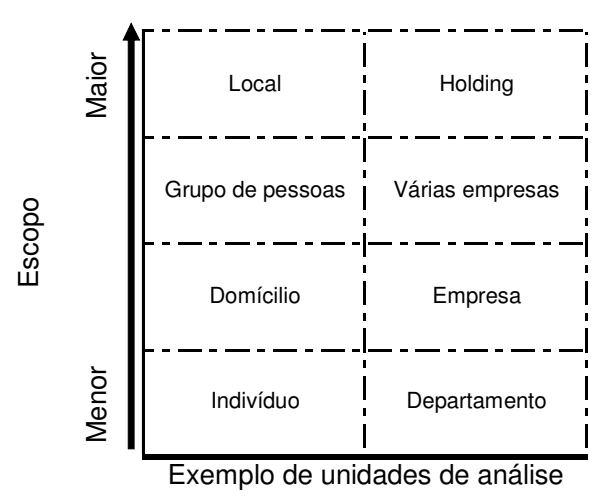

(a)

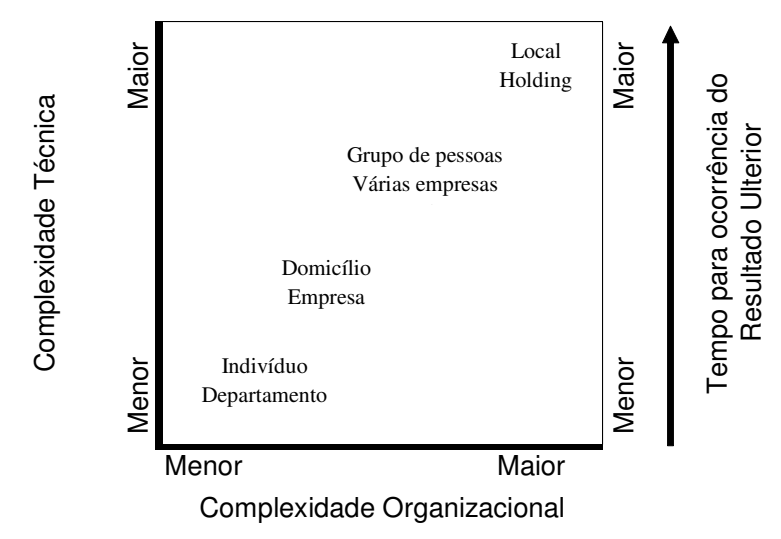

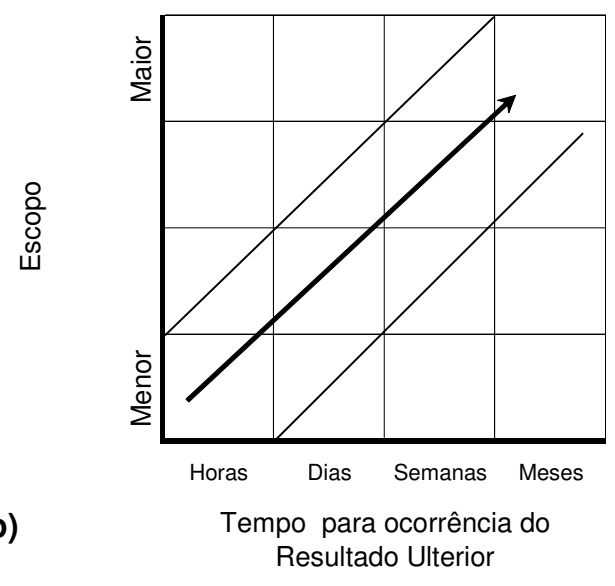

(b) Resultado Ulterior

(c)

FIGURA 3.16 - Tempo para ocorrência do efeito e complexidade de análise segundo o escopo

Fonte: Baseada nos trabalhos de Keating et al. (1999); Schneiderman (1988) e Roche (2002).

À luz da bibliografia, algumas considerações podem ser estabelecidas:

- como indica o item b) da Figura 3.16, os resultados ulteriores tornam-se evidentes mais rapidamente num escopo menor. Quanto maior o escopo considerado, eles tornam-se aparentes num horizonte de tempo cada vez maior;

- quanto maior o escopo dos resultados ulteriores, maior a dificuldade de analisá-los, pois eles são oriundos de um processo que se torna mais complexo. Como colocado por Keating et al. (1999) e Schneiderman (1988), a complexidade dos processos pode ser desdobrada em duas dimensões 
básicas. A primeira é a complexidade técnica. Esta se torna maior com o aumento do tempo de ciclo do processo, com a elevação da dificuldade de se realizar experimentos e com o maior grau de conhecimento requerido. A segunda dimensão é a complexidade organizacional. Ela aumenta à medida que mais funções, pessoas de diferentes áreas e background são envolvidas para operar o processo elevando a dificuldade de sua coordenação. Ao se aumentar a complexidade do processo torna-se mais difícil analisar as relações de causa e efeito, além disso, o efeito de uma ação sobre o processo demora mais tempo para aparecer. Esta relação é ilustrada no item c) da Figura 3.16.

$\mathrm{Na}$ mesma direção, Roche (2002) coloca que quanto maior o escopo dos resultados ulteriores mais eles são influenciados pela condição dos contextos macro, sejam eles social, econômico, ambiental e/ou político. Finalmente, quanto maior o tempo, maior a possibilidade dos fatores externos influenciarem.

Como os resultados ulteriores são influenciados também por fatores externos que não estão sob o controle direto do provedor de serviço, torna-se necessário o monitoramento dos principais fatores externos como um meio para se lidar com essa incerteza (PFEIFFER, 2000 e 2005) e (ROCHE, 2002). A identificação dos fatores externos e internos torna-se mais complexa à medida que se aumenta o escopo dos efeitos pretendidos.

Para considerar as possibilidades de controle do processo de serviço, os fatores externos podem ser divididos em dois tipos:

- Fatores externos sob o controle do cliente: esses fatores estão sob o controle do cliente, mas não sob o controle do provedor. Por exemplo: em uma academia de ginástica, se o objetivo é o emagrecimento, sua dieta alimentar influencia os resultados ulteriores almejados pelo mesmo, mas não está sob o controle direto da academia;

- Fatores externos exógenos ao cliente e ao prestador de serviço: são exemplos, as condições ambientais, sociais e econômicas de uma dada região que podem influenciar o comportamento do cliente e os resultados ulteriores almejados. 
Pfeiffer (2000) indica que serviços que visam produzir mudanças em pessoas ou organizações encontram necessariamente uma série de barreiras e riscos que dificilmente podem ser detectados na sua totalidade. Mesmo com a viabilidade analisada e confirmada, podem ocorrer mudanças desfavoráveis, capazes de comprometer seu êxito. Como demonstrado anteriormente, esta lógica se aplica a todos os SRUs. Apesar de os fatores externos escaparem à influência direta do prestador de serviço, é necessário realizar uma avaliação cuidadosa da sua influência para o sucesso do serviço, além de monitorar o seu comportamento ao longo do tempo. $\mathrm{Na}$ análise desses fatores externos, três aspectos necessitam ser considerados: i) a sua importância para o êxito do serviço; ii) a probabilidade de eles impactarem o serviço; iii) a possibilidade de tomada de ações para compensar as influências desses fatores sobre a eficácia do serviço. Caso não se consiga modificar essas influências, corre-se um grande risco de o serviço não ser eficaz. A Figura 3.17 mostra como esses fatores devem ser considerados.

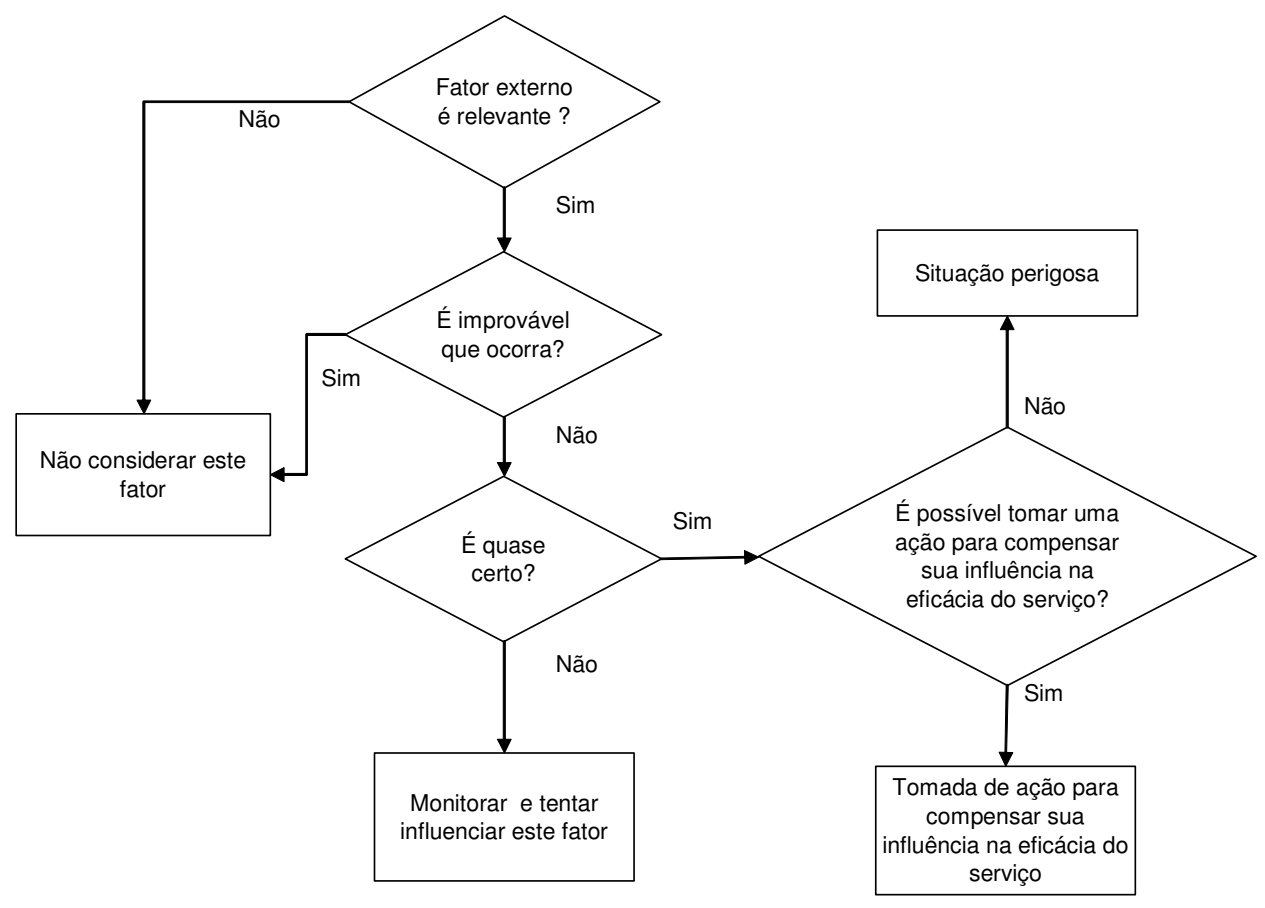

FIGURA 3.17 - Esquema para a apreciação dos fatores externos

Fonte: Baseada na Figura 6 de Pfeiffer (2000) 


\subsubsection{Táticas para incentivar mais participação e envolvimento do cliente}

Para incentivar mais participação e envolvimento do cliente como usuário, a fim de buscar os resultados ulteriores almejados, as seguintes duas táticas podem ser consideradas:

- Lovelock (1995) aponta que a empresa deve estabelecer uma comunicação eficiente com o cliente, disponibilizando informações relevantes sobre o serviço, como programação, preços, instruções para o uso dos serviços, lembretes, avisos, notificação de mudanças, etc.

- A empresa deverá também prover suporte ao cliente durante a realização das atividades, orientando, esclarecendo dúvidas e estimulando sua participação (ZEITHAML e BITNER, 2003).

\subsubsection{Cliente como um produto}

Trata-se de uma situação em que o produto - resultado buscado pelo processo de entrega do serviço - é a mudança de comportamento ou atitudes por parte do cliente ou a modificação de uma dada condição do cliente para outra. $O$ resultado esperado depende do interesse do cliente em mudar. O cliente tanto no papel de comprador como no de usuário, pode afetar o resultado na medida em que ele deve se interessar pelo serviço e realizar de modo adequado suas atividades.

\subsubsection{Cliente como concorrente ou parceiro}

Uma análise mais detalhada dos papéis que o cliente pode desempenhar revela a necessidade de incorporar um sexto papel ao modelo proposto por Lengnick-Hall (1996). Ele se faz presente nos SRUs, sendo importante para a 
obtenção dos efeitos pretendidos. A esse papel dar-se-á o nome de "cliente como concorrente ou parceiro". Em muitos serviços, a entrega não é feita somente para um cliente. Os clientes, muitas vezes, interagem com outros durante esse processo. Essa situação ocorre porque eles recebem o serviço simultaneamente com outros, ou porque devem esperar a sua vez, enquanto outros estão recebendo atendimento. Nesses casos, os outros clientes podem afetar - positivamente ou negativamente a natureza dos resultados. Trabalhos como de Bitner et al.(1997), Grove e Fisk (1997) e Zeithaml e Bitner (2003) realçaram este aspecto. Como bem exemplificaram Zeithaml e Bitner (2003)

[...] O sucesso da organização Vigilantes do Peso, por exemplo, depende significativamente da camaradagem e do apoio que os membros do grupo dão uns aos outros durante o processo de redução do peso.

A partir dessas considerações, todos os possíveis papéis que os clientes desempenham nos SRUs podem ser representados esquematicamente como na Figura 3.18, acrescentando o sexto papel e as interações causadas pelo mesmo na entrega do serviço. Neste sexto papel, um cliente pode colaborar com o outro ou agir de modo indesejável. Além disso, ele ainda pode competir com terceiros pelos recursos oferecidos pelo prestador de serviço. Vale ressaltar que a atuação como concorrente ou parceiro pode influenciar diretamente outro cliente como comprador e como usuário. Portanto, pode, também, afetar indiretamente o papel deste como produto.

Vários textos de marketing de serviços reportam a existência de clientes "abusivos", que normalmente prejudicam a experiência sobre o serviço de outros clientes. Como meio para inibir comportamentos indesejáveis, a literatura cita a adoção de algumas táticas:

- definição de regras de conduta que devem ser respeitadas pelos clientes quando utilizam os serviços;

- implementar programas de educação e orientação (aulas formais, folhetos, placas de orientação, etc.);

- recompensar os clientes pelo bom comportamento ou puni-los pelo mau comportamento; 
- administrar o composto de clientes de forma que segmentos conflitantes não se misturem (ZEITHAML e BITNER, 2003; LOVELOCK e WRIGHT, 2002; HOFFMAN e BATESON, 2003).

Muitas vezes, é desejável mais interação e aproximação entre os diferentes clientes. Nesta situação, a empresa deve buscar meios para promover mais socialização entre eles, utilizando, por exemplo, a estratégia de promoção de eventos sociais (ZEITHAML e BITNER, 2003).

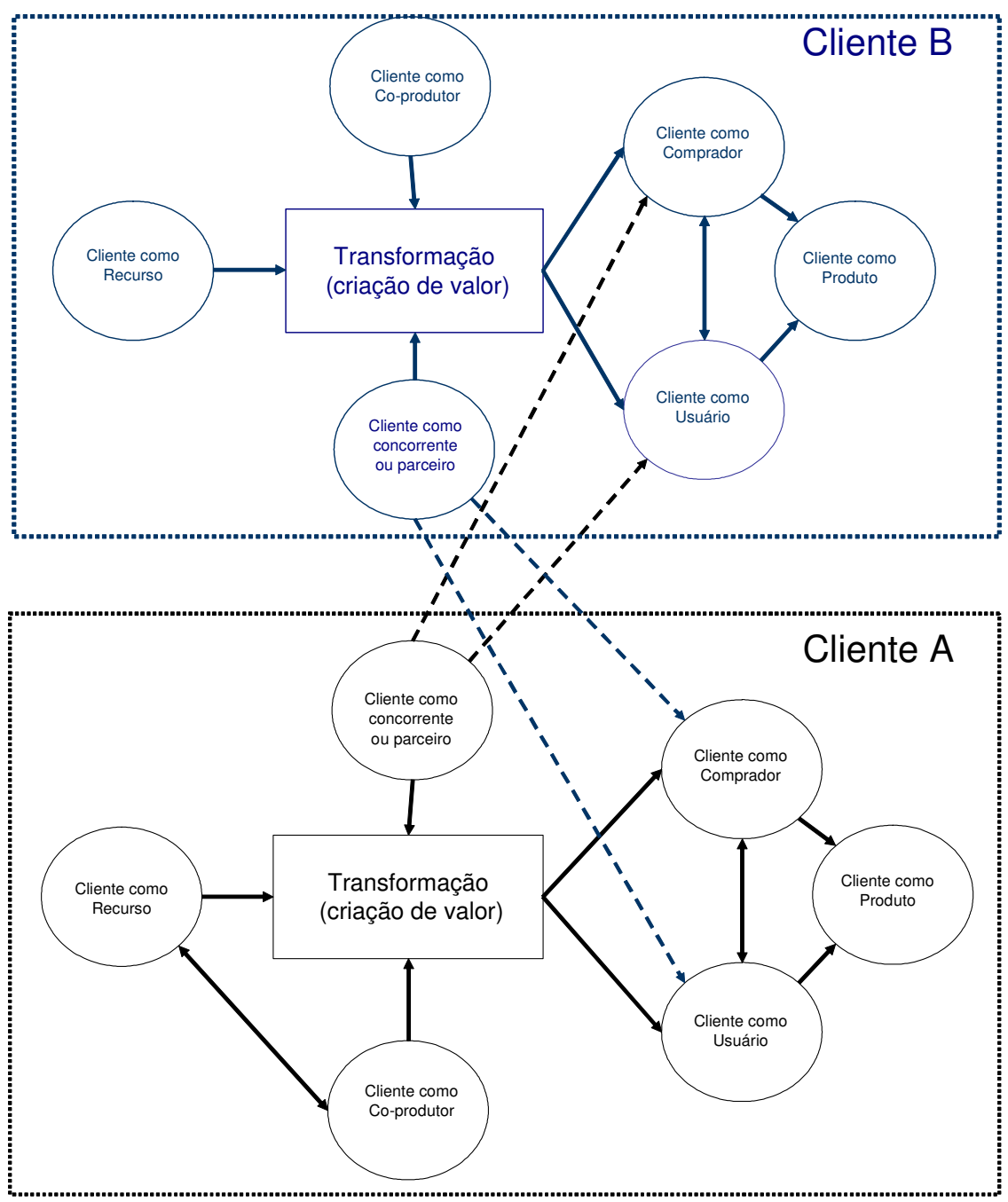

FIGURA 3.18 - Papéis desempenhados pelo cliente nos serviços

Fonte: Elaborada pelo autor com base nos trabalhos de Bitner et al.(1997), Grove e Fisk (1997), Lengnick-Hall (1996) e Zeithaml e Bitner (2003). 


\subsection{MEDIÇÃO DE DESEMPENHO}

A busca por um melhor desempenho se faz presente em todas as organizações de serviços. Vários objetivos/critérios de desempenho são discutidos na literatura. O Quadro 3.14 evidencia esta diversidade, comparando as diferentes relações de objetivos/critérios considerados por diferentes autores.

\begin{tabular}{|l|l|l|l|}
\hline Segundo Corrêa e Caon & $\begin{array}{l}\text { Segundo Fitzsimmons e } \\
\text { Fitzsimmons }\end{array}$ & Segundo Johnston e Clark & $\begin{array}{l}\text { Segundo Corrêa e } \\
\text { Gianesi }\end{array}$ \\
\hline Acesso & Confiabilidade & Confiabilidade & Acesso \\
Comunicação & Conveniência & Atendimento \\
Conforto & Disponibilidade & Corviços & Disponibilidade \\
Consistência Competência & Personalização & Exclusividade & Consistência \\
Atendimento & Preço & Flexibilidade & Credibilidade \\
Custo & Qualidade & Preço & Custo \\
Estética & Rapidez & Qualidade & Flexibilidade \\
Flexibilidade & Reputação & Velocidade de serviços & Velocidadade \\
Integridade & Vegudo serviço & \\
Limpeza & & & \\
Qualidade dos bensa & & \\
Segurança & & & \\
Velocidade & & & \\
\hline
\end{tabular}

QUADRO 3.14 - Objetivos/critérios competitivos para operações de serviços

Fonte: Corrêa e Caon (2002); Fitzsimmons e Fitzsimmons (2000); Johnston e Clark (2002) e Corrêa e Gianesi (1994)

Conforme observado por Skinner (1969), vários dos objetivos/critérios de desempenho podem estar inter-relacionados. Em alguns casos, existem relações de compromisso ou trade-off entre eles. Os trade-offs existentes em cada operação impõem restrições ao sistema produtivo, fazendo com que a operação renuncie a um desempenho superior em alguns critérios para favorecer outros (MAPES; NEW e SZWEIJCZEWSKI, 1997).

Os trade-offs existem, mas não são de natureza estática, e as relações entre eles podem ser alteradas de diversas maneiras. Um modelo utilizado para explicar esse comportamento foi proposto por Silveira e Slack (2001). Estes autores recorrem à analogia de uma gangorra apoiada sobre um pivô e sua base. Este modelo serve para retratar os três modos de trade-off que podem ocorrer: i) uma melhoria de desempenho no critério competitivo A que afeta negativamente o desempenho no 
critério $\mathrm{B}$; ii) uma melhoria de desempenho no critério competitivo $A$ obtida sem prejudicar o desempenho no critério competitivo $B$; e iii) uma mudança no sistema ${ }^{10}$ possibilita uma melhoria de desempenho em ambos critérios competitivos $\mathrm{A}$ e $\mathrm{B}$, sem provocar uma mudança relativa entre eles. Essas três situações estão retratadas na Figura 3.19. Em face dessas considerações, pode-se afirmar que, embora existam trade-offs de desempenho entre alguns pares de critérios competitivos, é possível neutralizá-lo ou ainda elevar conjuntamente o desempenho do par de critérios envolvido. Dessa forma, a empresa poderá encontrar meios para superar a concorrência simultaneamente em mais de um critério.

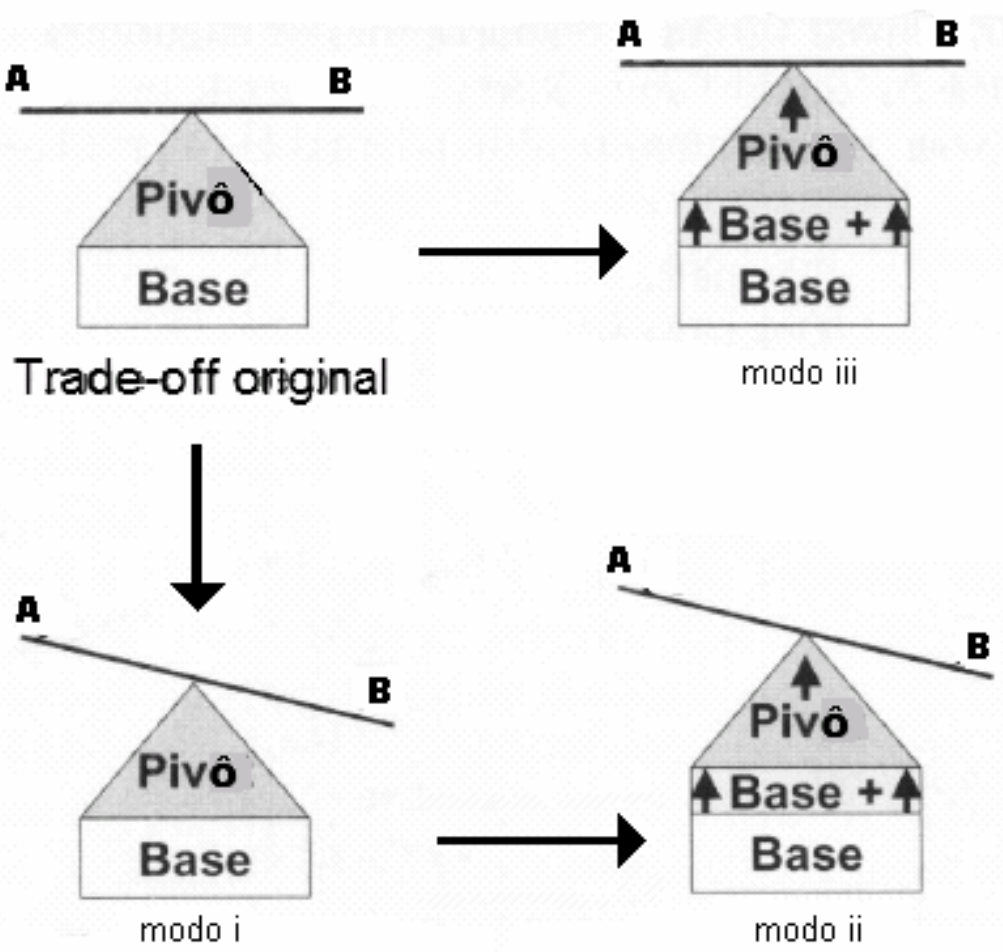

FIGURA 3.19 - Modos de trade-offs

Fonte: Adaptada da Figura 3 de Silveira e Slack (2001).

\footnotetext{
${ }^{10}$ Obtida por intermédio de mudanças nos recursos (tecnologias, métodos e conhecimentos) e/ou mudanças nos processos, atividades ou funções desempenhadas dentro do sistema.
} 
Hronec (1994) entende que a medição de desempenho traz equilíbrio às operações da empresa ao ser empregada em toda a organização de forma a interligar estratégia e processos. Na visão deste autor, existem dois tipos de medidas de desempenho: i) Medidas de desempenho de processo que monitoram as atividades de um processo e motivam as pessoas participantes; ii) Medidas de desempenho de output que verificam os resultados de um processo e são utilizadas para controlar os recursos. As medidas de output podem ser financeiras ou nãofinanceiras. Este autor acrescenta que há três critérios para a medição de desempenho: i) Qualidade que quantifica a "excelência" do produto ou serviço; ii) Tempo que quantifica a "excelência" do processo; iii) Custo que quantifica o lado econômico da "excelência". A empresa deve criar medidas de desempenho em três níveis distintos: i) nível da organização, em que as medidas estão mais orientadas para o output; ii) nível dos processos que cruzam as fronteiras funcionais - é intermediária e orientada para o processo; iii) nível dentro das funções com orientação às pessoas. O Quadro 3.15 ilustra o escopo e a aplicação dos três critérios para a medição de desempenho nos três níveis.

\begin{tabular}{|c|c|c|c|c|}
\hline & \multicolumn{3}{|c|}{ Critérios } \\
\hline & & Custo & Qualidade & Tempo \\
\hline \multirow{3}{*}{$\sum_{\bar{z}}^{\bar{\Phi}}$} & 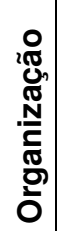 & $\begin{array}{l}\text { Financeiro } \\
\text { Operacional } \\
\text { Estratégico }\end{array}$ & $\begin{array}{c}\text { Empatia } \\
\text { Produtividade } \\
\text { Confiabilidade } \\
\text { Credibilidade } \\
\text { Competência }\end{array}$ & $\begin{array}{c}\text { Velocidade } \\
\text { Flexibilidade } \\
\text { Responsividade } \\
\text { Maleabilidade }\end{array}$ \\
\hline & 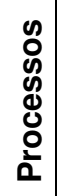 & $\begin{array}{l}\text { inputs } \\
\text { Atividades }\end{array}$ & $\begin{array}{l}\text { Conformidade } \\
\text { Produtividade }\end{array}$ & $\begin{array}{l}\text { Velocidade } \\
\text { Flexibilidade }\end{array}$ \\
\hline & 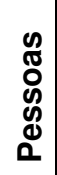 & $\begin{array}{c}\text { Remuneração } \\
\text { Desenvolvimento } \\
\text { Motivação }\end{array}$ & $\begin{array}{l}\text { Confiabilidade } \\
\text { Credibilidade } \\
\text { Competência }\end{array}$ & $\begin{array}{l}\text { Responsividade } \\
\text { Maleabilidade }\end{array}$ \\
\hline
\end{tabular}

QUADRO 3.15 - Exemplos referentes aos três critérios de indicadores nos três níveis da empresa Fonte: Baseado na Figura 2.1 de Hronec (1994) 
No início da década de 1990, Robert Kaplan e David Norton criaram a ferramenta denominada Balanced Scorecard (BSC) para avaliar o desempenho da organização. O modelo do BSC busca prover respostas para quatro perguntas básicas: i) Como os consumidores nos vêem? (perspectiva do consumidor); ii) Em que devemos nos exceder? (perspectiva dos processos internos); iii) Como nós continuaremos a melhorar e a criar valor? (perspectiva da aprendizagem e crescimento) iv) Como atendemos aos nossos acionistas? (perspectiva financeira). A Figura 3.20 ilustra essas quatro perspectivas no modelo BSC (KAPLAN e NORTON, 1997).

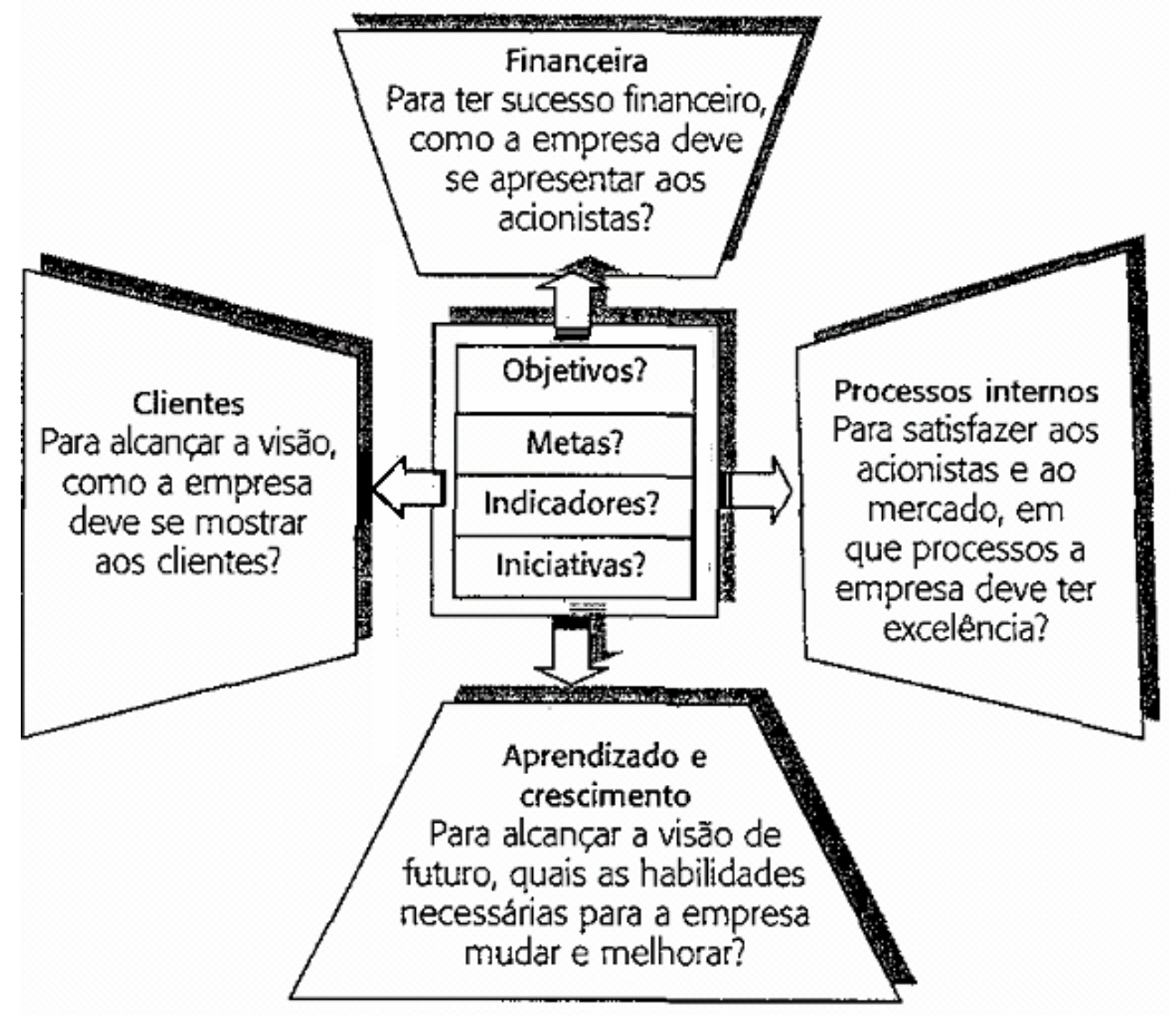

FIGURA 3.20 - Perspectivas estratégias de negócio

Fonte: Kaplan e Norton (1997) 
A perspectiva financeira leva em consideração as três fases do ciclo de vida da organização: i) crescimento - nesta fase os objetivos financeiros típicos serão percentuais de crescimento da receita e de aumento de vendas em determinados mercados; ii) sustentação - nesta fase os objetivos financeiros se voltam à busca da lucratividade; iii) colheita - nesta fase, os objetivos financeiros típicos referem-se à maximização do fluxo de caixa em prol da organização (KAPLAN e NORTON, 1997).

Na perspectiva dos clientes, as medidas essenciais referem-se às propostas de valor criadas para os clientes, variando de acordo com o setor de atividade. Elas se dividem em três categorias: i) valor de produtos ou serviços - abrange a funcionalidade do produto ou serviço, o preço e a qualidade; ii) valor do relacionamento com os clientes - entrega do produto ou serviço; iii) valor da imagem e reputação - relacionada aos fatores intangíveis que atraem um cliente para a empresa (KAPLAN e NORTON, 1997).

Na perspectiva de processos internos, as medidas são escolhidas de maneira a alavancar a excelência em situações críticas para atingir a estratégia estabelecida. Sob esta perspectiva, Souza et al. (2005) sugerem a adoção de vários indicadores, como mostrados no Quadro 3.16.

\begin{tabular}{|c|c|c|}
\hline Processo & Tipo de indicador & Indicador \\
\hline \multirow[t]{2}{*}{ Inovação } & Pesquisa básica e aplicada & $\begin{array}{l}\text { - Percentual de vendas gerado por novos produtos } \\
\text { - Lançamento de novos produtos versus concorrentes } \\
\text { - Capacidade técnica do processo de produção } \\
\text { - Lucro operacional (5 anos) sobre custo de desenvolvimento, }\end{array}$ \\
\hline & Desenvolvimento de produtos & $\begin{array}{l}\text { - \% volume de produção com sucesso no mercado para cada } \\
\text { subprocesso } \\
\text { - Tempo de ciclo para cada subprocesso } \\
\text { - Introdução de novos produtos }\end{array}$ \\
\hline \multirow[t]{3}{*}{ Operações } & Medidas de tempo & $\begin{array}{l}\text { - Tempo de ciclo } \\
\text { - Tempo de armazenamento inicial, final e em processo }\end{array}$ \\
\hline & Medidas de qualidade & $\begin{array}{l}\text { - Taxa de defeito em perdas por milhão (por processo) } \\
\text { - Desperdício }\end{array}$ \\
\hline & Custo & - Custo de cada subprocesso \\
\hline \multirow{3}{*}{$\begin{array}{l}\text { Serviço pós- } \\
\text { venda }\end{array}$} & Tempo & - Tempo do ciclo: solicitação do cliente até a resolução final \\
\hline & Qualidade & - \% de solicitações atendidas com uma visita \\
\hline & Custo & - Custo dos recursos utilizados \\
\hline
\end{tabular}

QUADRO 3.16 - Possíveis indicadores para a perspectiva de processos internos Fonte: Quadro 5 de Souza et al. (2005) 
$\mathrm{Na}$ perspectiva do aprendizado e crescimento, são três as categorias de objetivos: i) capacidade dos funcionários; ii) capacidade dos sistemas de informação e iii) motivação, empowerment e alinhamento. Sob esta perspectiva, Souza et al. (2005) sugerem a adoção de vários indicadores, como demonstra o Quadro 3.17.

\begin{tabular}{|c|c|}
\hline Categoria & Medida ou indicador \\
\hline $\begin{array}{l}\text { Capacidade dos } \\
\text { funcionários }\end{array}$ & $\begin{array}{l}\text { - Satisfação dos funcionários } \\
\text { - Retenção dos funcionários } \\
\text { - Produtividade por funcionário } \\
\text { - Lucratividade por funcionário }\end{array}$ \\
\hline $\begin{array}{l}\text { Capacidade dos } \\
\text { sistemas de informação }\end{array}$ & $\begin{array}{l}\text { - Índice de cobertura de informações estratégicas } \\
\text { - \% de processos que oferecem retorno em tempo real sobre qualidade, tempo e } \\
\text { custo } \\
\text { - \% de funcionários que lidam diretamente com clientes e têm acesso online às } \\
\text { informações referentes a eles }\end{array}$ \\
\hline $\begin{array}{l}\text { Motivação, } \\
\text { empowerment e } \\
\text { alinhamento }\end{array}$ & $\begin{array}{l}\text { - Número de sugestões por funcionário } \\
\text { - Número de sugestões por funcionário implementadas } \\
\text { - Taxa de melhorias efetivas nos processos críticos } \\
\text { - Pesquisa interna sobre desenvolvimento de equipes } \\
\text { - Nível de ganhos compartilhados } \\
\text { - \% de planos de negócios desenvolvidos pelas equipes } \\
\text { - \% de todos os projetos com participação do cliente nos ganhos } \\
\text { - \% de projetos com incentivos individuais de equipes, vinculados ao sucesso do } \\
\text { projeto }\end{array}$ \\
\hline
\end{tabular}

QUADRO 3.17 - Possíveis indicadores para a perspectiva de aprendizado e crescimento Fonte: Quadro 6 de Souza et al. (2005)

Sink e Tuttle (1993) afirmam que o desempenho de uma empresa pode ser analisado utilizando-se sete critérios distintos que refletem o desempenho de um sistema organizacional, quais sejam: eficiência, eficácia, produtividade, qualidade, qualidade de vida no trabalho, criatividade e lucratividade. Estes autores propõem o modelo representado na Figura 3.21 para a definição dos critérios que possibilitam a avaliação do desempenho de um sistema organizacional. 


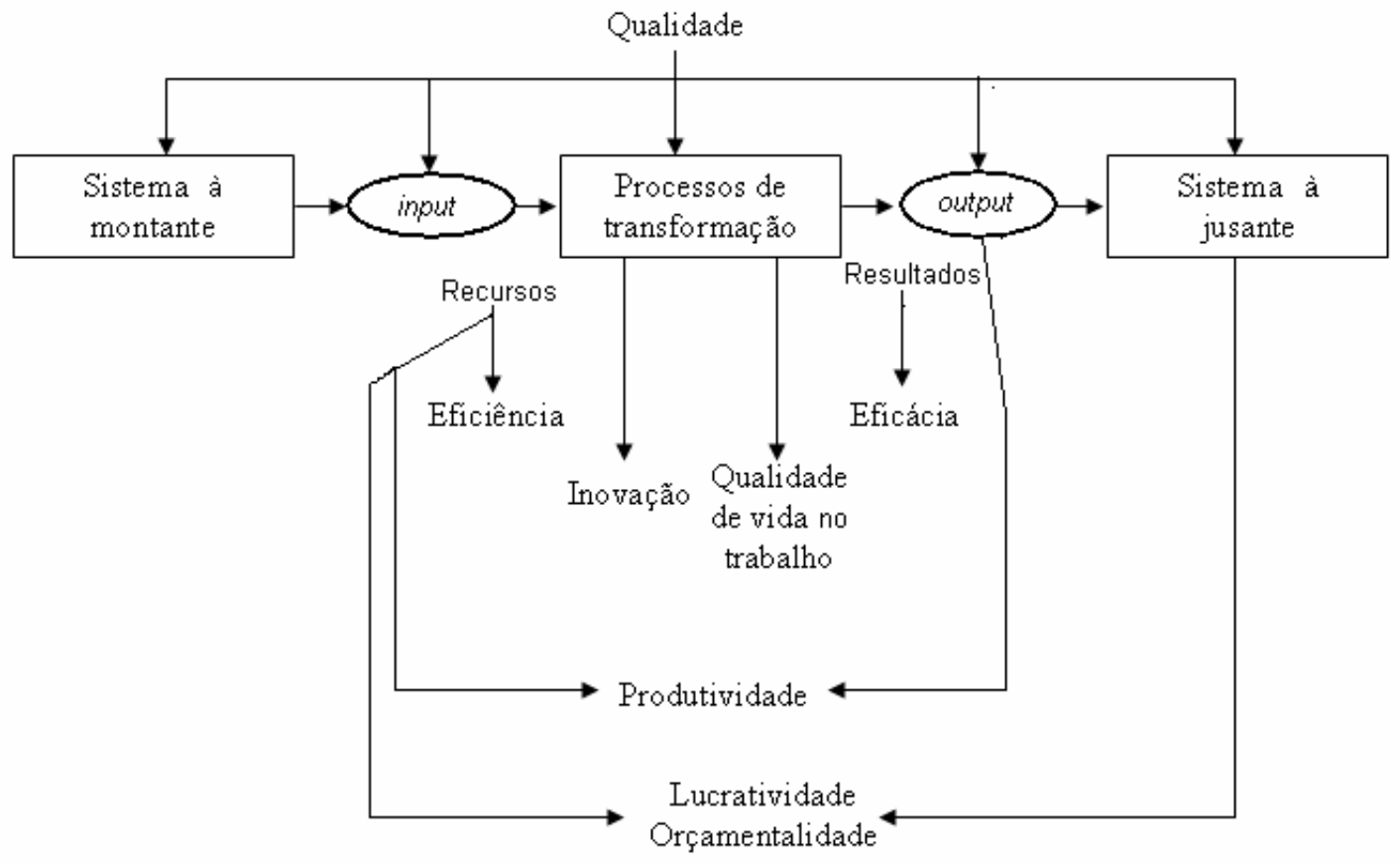

FIGURA 3.21 - Sete critérios para a avaliação do desempenho de um sistema organizacional

Fonte: Baseada na Figura 5.2 de Sink e Tuttle (1993)

Segue uma breve descrição do significado desses sete critérios, de acordo com a visão de Sink e Tuttle (1993):

- Eficiência: está associada ao consumo de recursos e pode ser visualizada no lado referente aos inputs. Pode ser definida como a relação entre consumo previsto e consumo efetivo de recursos. Se o índice for maior do que um, então o sistema foi mais eficiente do que se esperava, uma vez que consumiu menos recursos do que o previsto; se for menor do que um, o sistema foi menos eficiente. Espera-se, também, que a eficiência aumente com o passar do tempo.

- Eficácia: deve traduzir a forma pela qual o sistema realiza aquilo a que se propôs, bem como refletir a natureza dos resultados por ele alcançados frente aos objetivos corretos buscados. O conceito de objetivo correto contra o qual 
os resultados são confrontados estará sempre sujeito à interpretação, ao critério, ao julgamento e à percepção de pessoas ou grupo de pessoas. A eficácia pode ser entendida como a realização efetiva das coisas certas, pontualmente e dentro dos requisitos de qualidade especificados. Ela pode ser medida pela relação entre resultados obtidos e previstos. O conceito de ser mais ou menos eficaz depende do resultado desta relação. É uma medida comparativa que deve ser observada ao longo de períodos subseqüentes.

- Qualidade: como parâmetro de desempenho, é mais difusa no sistema organizacional em função de sua importância em todos os estágios de gerenciamento do sistema. Ela é definida operacionalmente por meio de cinco pontos de verificação: i) o primeiro ponto se dá no sistema à montante do sistema organizacional e compreende um conjunto de atividades que garantem a adequação dos recursos; ii) segundo ponto, na interface entre o sistema à montante e o sistema organizacional, verifica se o processo está efetivamente recebendo os recursos que necessita; iii) terceiro diz respeito ao processo de transformação do próprio sistema organizacional, contemplando a criação de qualidade no produto ou serviço realizado; iv) quarto ponto de verificação está na interface entre o sistema organizacional e o sistema à jusante, para garantir que os produtos e resultados, gerados pelo sistema organizacional, satisfaçam às especificações e aos requisitos estabelecidos; v) quinto ponto de verificação considera o sistema à jusante e deve refletir a compreensão daquilo que os clientes querem, precisam e exigem, além da forma como estão reagindo à entrega dos bens e/ou serviços que o sistema organizacional está fornecendo.

- Qualidade de vida no trabalho: pode ser caracterizada pela resposta ou reação afetiva das pessoas do sistema organizacional. Na visão esquemática apresentada na Figura 3.21, observa-se que ela se relaciona com o terceiro ponto de verificação de qualidade, em que o sistema organizacional cria a qualidade do produto ou serviço que realiza. O modo como os indivíduos se sentem a respeito dos fatores que consideram importantes para sua vida na organização é fundamental no desempenho do processo de transformação do 
sistema organizacional. Esta visão não sugere que as pessoas felizes sejam produtivas, nem que aquelas produtivas sejam felizes. Contudo, é inegável que existe uma relação complexa e importante entre qualidade de vida no trabalho e desempenho do sistema organizacional. As pesquisas realizadas neste campo ainda se mostram inconsistentes quando tentam estabelecer uma relação entre atitudes pessoais, sentimentos e desempenho profissional.

- Criatividade ou inovação: pode ser entendida como a capacidade criativa para mudar aquilo que o sistema organizacional faz e, também, o modo de fazer. Abrange mudanças importantes na estrutura da organização, na tecnologia, nos produtos, nos serviços, nos procedimentos, nas políticas e em outros aspectos julgados necessários.

- Lucratividade: pode ser definida como a relação entre o resultado financeiro alcançado pelo sistema organizacional e os custos assumidos neste esforço. O resultado financeiro é decorrente dos efeitos que os outputs provocam no sistema à jusante. O preço do produto ou serviço elaborado pelo sistema organizacional bem como dos recursos consumidos pelo mesmo impactam seu desempenho. Por intermédio do lucro é possível expandir a empresa, criar novos produtos e novas tecnologias. Necessariamente, uma empresa precisa gerar lucros para sobreviver. Já uma organização sem fins lucrativos deve ter a capacidade de operar com equilíbrio financeiro, respeitando suas disponibilidades orçamentárias, para que seja sustentável no longo prazo. Nessas organizações o parâmetro lucratividade deve ser substituído pela "orçamentalidade".

- Produtividade: é uma relação entre os outputs gerados por um dado sistema organizacional e os inputs que propiciaram a geração desses outputs. Ela implica no estabelecimento de duas categorias básicas de medidas: i) produtividade estática, originária da divisão das medidas dos outputs pelas medidas dos inputs, num dado período de tempo; ii) produtividade dinâmica, definida como a relação entre medidas da produtividade estática em períodos diferentes, refletindo a variação da produtividade de um período para outro. Para cada uma dessas categorias, podem ser considerados três tipos de 
medidas de produtividade: parcial, múltipla e total. Cada um desses tipos é uma função da quantidade de inputs considerados no denominador da relação entre outputs e inputs, que define a produtividade. Assim, ao considerar somente uma classe de input, mede-se uma produtividade parcial. Se mais de uma classe de input são consideradas, tem-se uma medida de produtividade múltipla. Se todas as classes de inputs são consideradas, temse a produtividade total.

A medição da produtividade de serviços é bem mais complexa do que a medição de produtividade na fabricação de bens. Portanto, é importante aprofundar a sua discussão, destacando-a na relação dos sete critérios enumerados por Sink e Tuttle (1993).

A produtividade de uma operação está diretamente relacionada à eficácia com que os recursos em um processo (seja industrial ou de serviço) são transformados em resultados econômicos para o provedor de serviço e valor para seus clientes. Dentro desta lógica, uma alta produtividade contribui para gerar lucro para o provedor de serviço, além de valor para seus clientes. Mas este conceito apresenta-se de uma forma simplificada e incompleta, na medida em que não esclarece se a qualidade permanece inalterada, caso a produtividade seja aumentada. Vários trabalhos (ARMISTEAD et al., 1988; GRONROOS e OJASALO, 2004; JOHNSTON e JONES, 2004) apontam que, no setor de serviços, isso pode não ocorrer. Por exemplo, uma empresa de serviço, que por algum tempo prioriza a redução de custo e o uso mais eficiente de seus recursos de produção, pode, dentro de um curto prazo, sofrer, como conseqüência, uma piora nos níveis de satisfação por parte de seus clientes, e, se a qualidade deteriora, a procura pelo seu serviço e os lucros tendem a cair. Nesta situação, pode-se perceber claramente que um uso mais eficiente dos recursos não implica necessariamente em uma melhoria da produtividade. Em outras palavras, os recursos de entrada não são usados de um modo mais efetivo. Portanto, para a avaliação do desempenho em serviços, um novo conceito de produtividade deve ser elaborado. Este setor convive com o dilema da produtividade, que consiste na difícil tarefa de balancear receitas com os custos. É preciso resgatar que o conceito de produtividade tradicional foi desenvolvido para os 
fabricantes de bens físicos como um conceito de eficiência de manufatura. Muitos dos modelos de produtividade e instrumentos de medida de produtividade existentes foram derivados do contexto de fabricantes. Assim, eles partem da suposição de que produção e consumo são processos separados, em que os clientes não participam no processo de produção. Embora as suas preferências sejam incorporadas nos produtos, os sistemas de produção industrial são fechados, e modelos de produtividade tradicionais e seus instrumentos de medida foram desenvolvidos para tais sistemas. Nos serviços, a simultaneidade entre o processo e consumo de serviço, em que os clientes participam ativamente, faz com que os recursos possam ser padronizados até certo grau, tornando-se difícil estimar a quantidade de inputs necessários para a realização de um dado output. As interações que são criadas pelo provedor de serviço e seus clientes influenciam a eficiência do processo de serviço (GRONROOS e OJASALO, 2004).

A produtividade não pode ser entendida sem levar em conta as inter-relações entre os recursos de entrada e a qualidade obtida com esses recursos. Ela também não pode ser entendida sem considerar a inter-relacão entre as eficiências interna ${ }^{11}$ e externa ${ }^{12}$. Isso é crucial para compreender e administrar a produtividade de serviço. Além disso, a produtividade é influenciada pela utilização da capacidade existente, ou seja, se a demanda é baixa, os recursos do provedor de serviço serão subutilizados (baixa eficiência interna). Por outro lado, quando a demanda começa a exceder a capacidade, pode-se ter um efeito negativo na qualidade de serviço percebida. Embora essa descrição seja altamente simplificada, a demanda também é um fator que afeta a produtividade (GRONROOS e OJASALO, 2004).

Com base nestas considerações, a visão da produtividade em serviços proposta por Gronroos e Ojasalo (2004), ilustrada na Figura 3.22, pode ser utilizada como um modelo que incorpora as inter-relações e aspectos que são peculiares aos processos encontrados no contexto de serviços.

\footnotetext{
${ }^{11}$ Eficiência interna se refere ao grau de aproveitamento dos recursos de Input (Pessoal, Infraestrutura, Tecnologia, etc.) para a produção dos serviços.

${ }^{12}$ Eficiência externa é sinônima de eficácia para estes autores e reflete como o sistema de prestação de serviços é capaz de atender aos objetivos de qualidade almejados pelos clientes.
} 


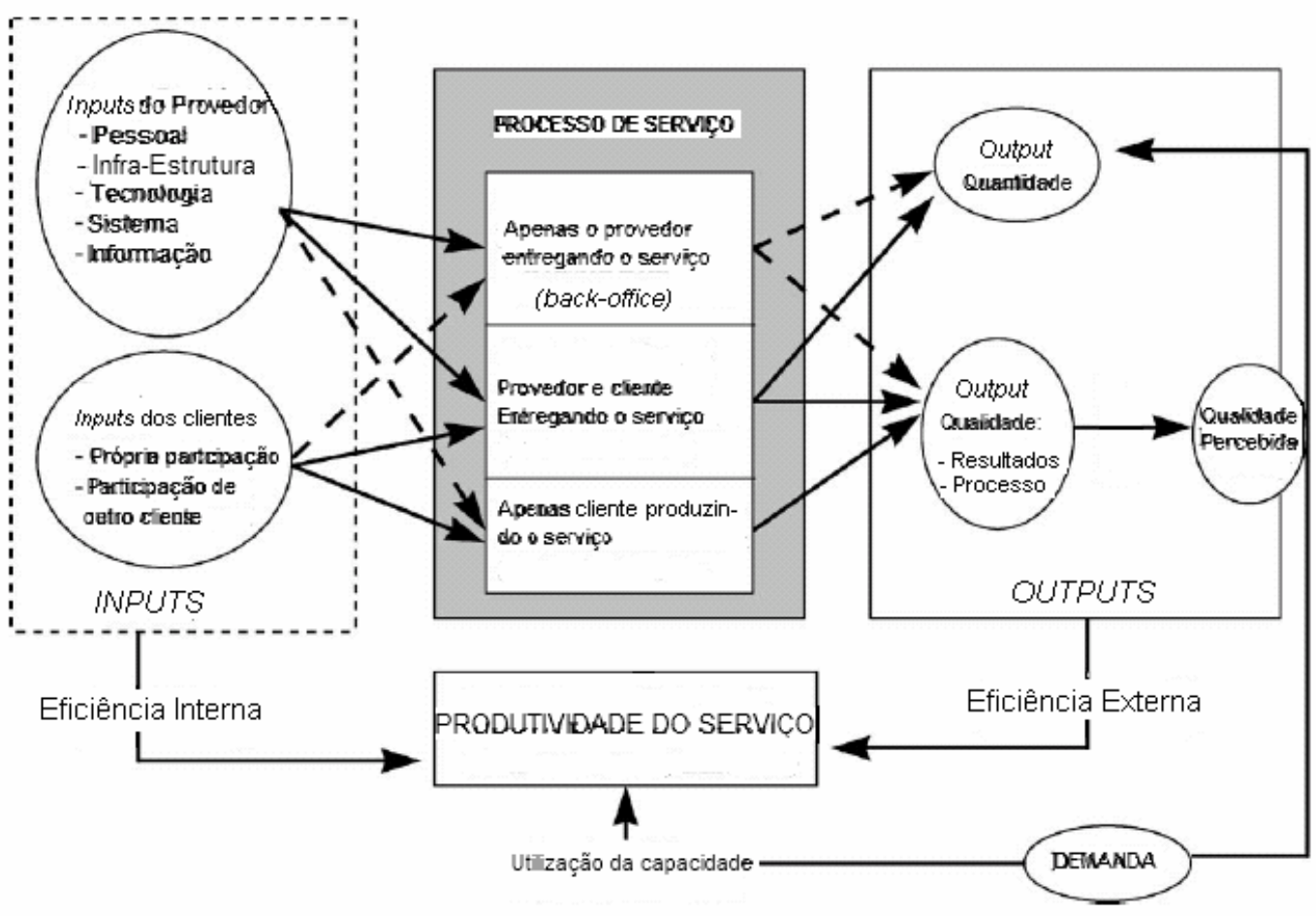

FIGURA 3.22 - Modelo para a produtividade em serviço

Fonte: Baseada na Figura 1 de Gronroos e Ojasalo (2004)

Segundo o modelo proposto por estes autores, três situações podem ocorrer no processo de serviço:

- apenas o provedor produz o serviço;

- tanto o provedor quanto o cliente produzem serviço por meio de interações;

- apenas o cliente produz o serviço, utilizando alguma infra-estrutura fornecida pelo provedor.

Os inputs para o provedor de serviço, como pessoal, tecnologia, sistemas, informações, etc., influenciam diretamente as duas primeiras situações de processo e, indiretamente, a terceira. Já os inputs do cliente (sua própria participação e a dos outros) afetam diretamente a segunda e a terceira situações de processo e, indiretamente, a primeira. Na Figura 3.22, as influências indiretas dos inputs são representadas por linhas tracejadas.

Quanto mais eficazmente uma organização de serviço usa seus próprios recursos de input - inclusive educando e guiando seu público, e provendo suporte 
adequado à produção do serviço - melhor será sua eficiência interna ${ }^{13}$ (OJASALO, 2003).

Do ponto de vista do provedor, quando os clientes produzem serviços independentes do provedor, não há nenhum efeito direto na eficiência interna. Porém, as percepções do cliente quanto à qualidade do serviço têm um impacto decisivo na eficiência externa e, deste modo, na produtividade de serviço (GRONROOS e OJASALO, 2004).

Os outputs do processo de serviço podem ser divididos em:

- quantidade de produção (volume), e

- qualidade de produção (processo e resultado).

A quantidade produzida depende da demanda.

Gronroos e Ojasalo (2004) consideram a produtividade de serviço como uma experiência de saber mútuo, na medida em que é dependente da capacidade de aprendizado do cliente para lidar com os vários aspectos do serviço, aprendendo, por exemplo, a evitar enganos e problemas de vários tipos. Tal aprendizado possibilita também ao público tornar-se mais ciente do que exatamente esperar do serviço, criando uma percepção mais adequada e favorecendo a qualidade percebida.

Conseqüentemente, a produtividade de serviço depende do progresso da relação entre o cliente e o provedor, na medida em que a competência do cliente em participar do processo de serviço de modo mais pessoal, mais rápido e suave, favorece a eficiência interna e pode também melhorar a eficiência externa, em termos de qualidade percebida (GRONROOS e OJASALO, 2004).

Lovelock e Wirtz (2006) propõem as seguintes estratégias genéricas para se aumentar a produtividade em serviços:

- forte controle de custos das etapas do processo;

- redução do desperdício de materiais ou de mão-de-obra;

\footnotetext{
${ }^{13}$ Bowen (1986) sugere que empresas de serviços adotem várias práticas voltadas à gestão de seus recursos humanos no tratamento dos próprios clientes.
} 
- ajuste da capacidade produtiva a níveis médios de demanda, diminuindo os períodos de ociosidade;

- substituição de trabalhadores por máquinas automatizadas;

- fornecimento de equipamentos e bancos de dados aos funcionários, possibilitando-Ihes trabalhar mais rapidamente ou com nível superior de qualidade;

- treinamento dos funcionários para trabalharem mais "produtivamente";

- ampliação do conjunto de tarefas que um profissional de serviço pode executar, eliminando gargalos e reduzindo ociosidade;

- instalação de sistemas especializados para que profissionais possam assumir parte do trabalho anteriormente realizado por outros mais experientes;

- envolvimento maior dos clientes na produção, colocando-os em um papel mais ativo no processo; e

- solicitação aos clientes para que usem terceiros na realização de algumas tarefas (serviços suplementares).

Os sete critérios de desempenho discutidos por Sink e Tuttle (1993) podem ser entendidos como abrangentes, mas não são mutuamente exclusivos em sua totalidade. Pode-se enxergar superposições entre alguns deles, por exemplo, a qualidade tem implicações tanto na eficácia como na produtividade. Mas eles formam um todo coerente que explica, de modo satisfatório, o relacionamento entre os critérios para que um sistema possa alcançar maior sustentabilidade e competitividade como indica a Figura 3.23. A importância dos critérios é dependente da situação e das peculiaridades do próprio sistema. É improvável que dois sistemas organizacionais ou gerentes distintos atribuam o mesmo peso aos mesmos critérios. É possível que um mesmo sistema pondere de forma diferente a importância desses critérios em épocas distintas. Um mérito deste modelo é o fato de que os critérios enumerados possibilitam levantar um conjunto de informações necessárias para que as equipes gerenciais possam administrar adequadamente o sistema organizacional. Como os critérios não definem indicadores específicos de desempenho, cada sistema deve identificar e criar seus indicadores específicos. 


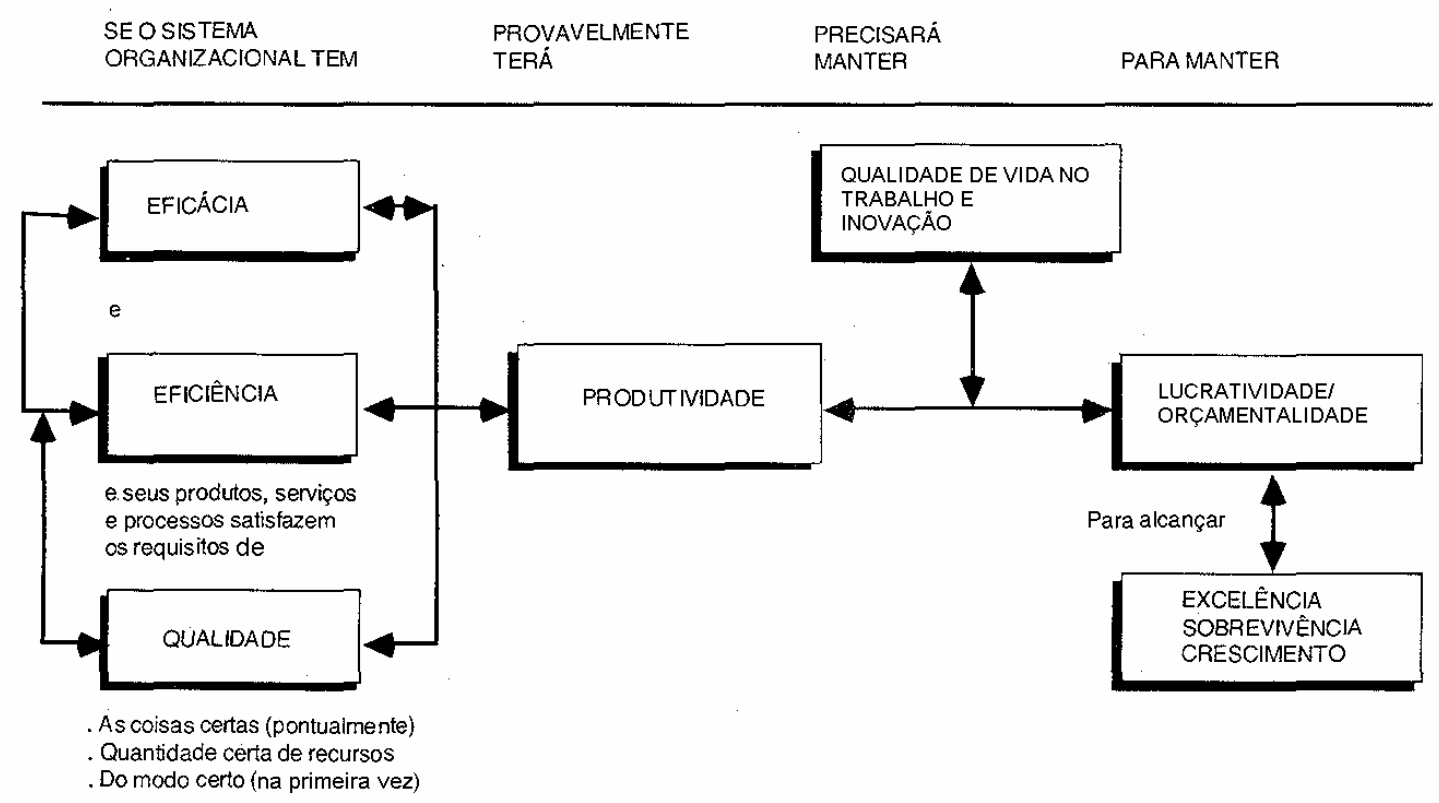

FIGURA 3.23 - Critérios para a avaliação do desempenho de um sistema organizacional

Fonte: Baseada na Figura 5.29 do Sink e Tuttle (1993)

Neely et al. (1997), ao revisarem vários trabalhos sobre medição de desempenho, identificaram várias características que uma boa medida de desempenho deveria ter:

- ser derivada da estratégia e alinhada às prioridades competitivas da operação;

- ser simples de entender e usar;

- prover feedback em tempo e de forma precisa;

- ser baseada em quantidades que possam ser influenciadas ou controladas pelo usuário ou por ele em conjunto com outros;

- refletir o processo de negócio da empresa, ou seja, deve levar em consideração as necessidades dos clientes e fornecedores em sua definição;

- referir-se a metas específicas;

- ser relevante;

- pertencer a um ciclo fechado completo de controle; 
- ser claramente definida;

— ter impacto visual;

— focalizar em melhoramento;

- manter seu significado ao longo do tempo;

- prover feedback rápido;

— ter propósito específico e definido;

- ser baseada em fórmulas e bases de dados explícitos;

- empregar mais índices que valores absolutos;

- referir-se mais a tendências que a situações estáticas;

- ser objetiva e não apenas opinativa; e

- ser mais global do que localizada.

Com base nessas características, Neely et al. (1997) sugerem a consideração de uma estrutura mínima que cada indicador deve contemplar. Estes autores desenvolveram um roteiro que abrange vários quesitos importantes, abordando também os comportamentos que as medidas de desempenho devem encorajar. Este roteiro foi baseado nas sugestões apontadas pela literatura e em uma pesquisa realizada com vários gerentes em organizações diversas. O Quadro 3.18 ilustra o roteiro proposto por estes autores.

\begin{tabular}{|l|l|}
\hline 1 - Título & $\begin{array}{l}\text { O título do indicador deve ser claro. Um bom título explica o que é o indicador e } \\
\text { por que ele é importante }\end{array}$ \\
\hline 2 - Propósito & O porquê do emprego do indicador deve ser explicitado \\
\hline 3 - Relacionado a & Deve ser expresso com que objetivos do negócio o indicador está relacionado \\
\hline 4 - Meta & Definir o nível de desempenho desejado \\
\hline 5 - Fórmula & Como indicador será calculado \\
\hline $\begin{array}{c}6 \text { - Freqüência de } \\
\text { Medição }\end{array}$ & $\begin{array}{l}\text { Freqüência deve ser adequada à realidade do processo, permitindo a tomada de } \\
\text { ações corretivas. }\end{array}$ \\
\hline 7 - Revisão da Freqüência & $\begin{array}{l}\text { A freqüência de medição deve ser periodicamente revista, verificando-se sua } \\
\text { adequação para fornecer feedback rápido. }\end{array}$ \\
\hline 8 - Quem mede? & A pessoa que coleta e reporta os dados \\
\hline 9 - Fonte de Dados & A fonte de dados primários deve ser especificada \\
\hline $\begin{array}{l}10-\text { Quem é o responsável } \\
\text { pelo indicador? }\end{array}$ & Nome da pessoa responsável por este indicador \\
\hline 11 - O que ele faz? & Explicitar o papel que cabe ao responsável \\
\hline $\begin{array}{l}12 \text { - Quem age com base } \\
\text { nos dados? }\end{array}$ & $\begin{array}{l}\text { Nome das pessoas que irão promover açães a partir das informações geradas. Se } \\
\text { ninguém age com base nos dados, o indicador não deve existir. }\end{array}$ \\
\hline 13 - O que eles fazem? & $\begin{array}{l}\text { Explicitar o papel que cabe às pessoas que agirão com base nas informações } \\
\text { geradas pela medição }\end{array}$ \\
\hline 14 - Notas e Comentários & Listar notas e comentários que se fizerem necessários \\
\hline
\end{tabular}

QUADRO 3.18 - Roteiro para definição de um indicador

Fonte: Neely et al. (1997) 


\subsection{FRAMEWORK TEÓRICO}

Vários aspectos relacionados aos SRUs foram discutidos neste capítulo. À luz do referencial teórico exposto e resgatando o objetivo desta tese de desenvolver subsídios à gestão de empresas de SRUs que processam pessoas, discutindo e elucidando como um sistema de monitoramento e controle e a adoção de táticas que estimulam o envolvimento e a participação dos clientes podem contribuir para que tais empreendimentos obtenham um melhor desempenho, esta seção define a estrutura conceitual na qual a pesquisa irá se apoiar.

Três temas inter-relacionados são abrangidos pelo framework teórico, quais sejam:

- sistema de monitoramento e controle voltado para o relacionamento com o cliente;

- táticas que estimulam o envolvimento e a participação dos clientes no serviço;

- desempenho do serviço.

Estes três temas serão tratados, em maior profundidade nas seções seguintes, tomando-se como referência os seis papéis que os clientes normalmente desempenham nos SRUs.

\subsubsection{Sistema de monitoramento e controle}

Sua importância para os SRUs se evidência na medida em que permite a adoção de ajustes e correções por parte do provedor de serviço, na busca dos resultados ulteriores pretendidos.

A estrutura de monitoramento adotada por empresas de SRUs pode ser descrita pelo Mapa de Relacionamento, exposto na Figura 3.15, que facilita a visualização das diferentes seqüências, episódios e atos que ocorrem na realização 
do serviço, bem como dos dados que são registrados pela empresa nessas interações.

Entende-se que o sistema de monitoramento e controle poderá registrar e analisar quatro tipos de informações:

- informações referentes às atividades realizadas/produtos imediatos. Exemplos: tempo de permanência no local, atividades realizadas no dia, freqüência etc.;

- informações sobre os resultados ulteriores. Exemplos: nota final obtida no exame simulado em um curso preparatório, redução de peso em um programa de musculação, quantidade de pessoas inseridas no mercado de trabalho por uma entidade que fomenta a re-inserção social, etc.;

- informações sobre alguns fatores externos que estão sob o controle do cliente e que podem influenciar os resultados ulteriores do serviço. Exemplo: realização de dieta ao longo de um programa de musculação, etc.;

- informações sobre alguns fatores externos que não estão sob o controle do cliente e que podem influenciar os resultados ulteriores do serviço. Exemplo: influência familiar sobre o jovem que realiza um curso para inclusão no mercado de trabalho.

Como o processo de um SRU envolve relacionamento com cliente por um período significativamente extenso, no presente trabalho admite-se que o sistema de monitoramento e controle a ser considerado deve abranger duas grandes fases. A primeira contempla a fase de entrada do cliente no serviço. Para que este possa ser processado, a empresa poderá realizar um procedimento de seleção, definindo sua inclusão ou não, e/ou um procedimento de diagnóstico, definindo a maneira e a freqüência do serviço a ser realizado. A segunda fase consiste no monitoramento do cliente durante a realização do serviço até sua finalização. O Quadro 3.19 apresenta estas duas fases à luz dos papéis desempenhados pelo cliente e das práticas desejáveis. 


\begin{tabular}{|c|c|c|}
\hline \multicolumn{2}{|r|}{ Papel do Cliente } & Atividades realizadas \\
\hline \multirow{2}{*}{ 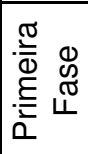 } & \multirow{2}{*}{ Cliente como recurso } & Sistemática de Seleção \\
\hline & & Sistemática de Diagnóstico \\
\hline \multirow{5}{*}{ 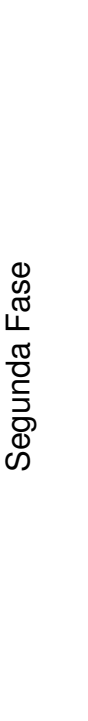 } & $\begin{array}{l}\text { Cliente como co- } \\
\text { produtor }\end{array}$ & \multirow{3}{*}{$\begin{array}{l}\text { Acompanhamento das atividades } \\
\text { realizadas pelo cliente. } \\
\text { Realização de correções e ajustes no } \\
\text { processo de serviço }\end{array}$} \\
\hline & $\begin{array}{l}\text { Cliente como } \\
\text { concorrente ou } \\
\text { parceiro }\end{array}$ & \\
\hline & $\begin{array}{l}\text { Cliente como } \\
\text { comprador }\end{array}$ & \\
\hline & Cliente como usuário & \begin{tabular}{|l|} 
Acompanhamento de fatores externos \\
que influenciam os resultados ulteriores
\end{tabular} \\
\hline & Cliente como produto & $\begin{array}{l}\text { Acompanhamento dos resultados } \\
\text { ulteriores intermediários e finais. }\end{array}$ \\
\hline
\end{tabular}

QUADRO 3.19 - Sistema de monitoramento e controle

Fonte: Elaborado pelo Autor (2007)

A avaliação da adequação do modo como o sistema de monitoramento e controle funciona nos processos de serviços de uma empresa ou entidade de SRU requer a definição de um método estruturado. Assim sendo, considerando as principais atividades que devem constituir o sistema de monitoramento e controle, descritas no Quadro 3.19, no presente trabalho definiu-se mais especificamente quais seriam as características e práticas correspondentes a cada uma destas atividades. Trata-se de um desdobramento necessário na medida que o mesmo possibilita uma avaliação mais criteriosa e objetiva do sistema de monitoramento e controle implementado em empresas ou entidades de SRUs. Assim, o Quadro 3.20 relaciona as diferentes características e práticas que deverão ser verificadas e avaliadas para julgar adequação do sistema de monitoramento e controle. 


\begin{tabular}{|c|c|c|c|c|c|c|}
\hline & Atividades & \multicolumn{2}{|c|}{ № - Caracteristica/prática } & \multicolumn{3}{|c|}{ Valor a ser atribuído } \\
\hline \multirow{2}{*}{ 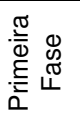 } & Procedimento de Seleção & 1 & Seleção dos clientes & 0 & 1 & 2 \\
\hline & Procedimento de Diagnóstico & 2 & Diagnóstico no ingresso do cliente. & 0 & 1 & 2 \\
\hline \multirow{12}{*}{ 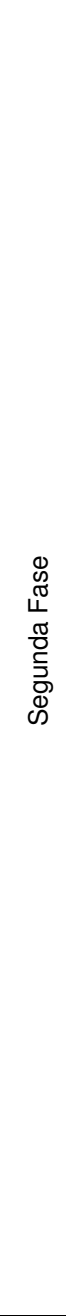 } & \multirow{3}{*}{$\begin{array}{l}\text { Acompanhamento das atividades } \\
\text { realizadas pelo cliente }\end{array}$} & 3 & Densidade dos atos registrados. & 0 & 1 & 2 \\
\hline & & 4 & $\begin{array}{l}\text { Grau de formalização das rotinas de coleta de } \\
\text { dados. }\end{array}$ & 0 & 1 & 2 \\
\hline & & 5 & $\begin{array}{l}\text { Grau de detalhamento dos dados que são } \\
\text { registrados. }\end{array}$ & 0 & 1 & 2 \\
\hline & & 6 & $\begin{array}{l}\text { Tomada de ação quando o cliente apresenta } \\
\text { uma freqüência baixa }\end{array}$ & 0 & 1 & 2 \\
\hline & & 7 & $\begin{array}{l}\text { Periodicidade da análise dos resultados } \\
\text { ulteriores intermediários }\end{array}$ & 0 & 1 & 2 \\
\hline & $\begin{array}{l}\text { Realização de correções e ajustes no } \\
\text { processo de serviço }\end{array}$ & 8 & $\begin{array}{l}\text { Tomada de ação quando não se antige os } \\
\text { resultados ulteriores intermediários almejados }\end{array}$ & 0 & 1 & 2 \\
\hline & & 9 & $\begin{array}{l}\text { Periodicidade da análise dos fatores externos } \\
\text { sob o controle do cliente }\end{array}$ & 0 & 1 & 2 \\
\hline & & 10 & $\begin{array}{l}\text { Tomada de ação na ocorrência de fatores } \\
\text { externos desfavoráveis ao atingimento dos } \\
\text { resultados ulteriores almejados sob o controle } \\
\text { do cliente }\end{array}$ & 0 & 1 & 2 \\
\hline & Acompanhamento de fatores externos & 11 & $\begin{array}{l}\text { Acompanhamento de fatores externos sob } \\
\text { controle do cliente que influenciam os resultados } \\
\text { ulteriores }\end{array}$ & 0 & 1 & 2 \\
\hline & que influenciam os resultados ulteriores & 12 & $\begin{array}{l}\text { Acompanhamento de fatores externos fora do } \\
\text { controle do cliente e empresa que influenciam } \\
\text { os resultados ulteriores }\end{array}$ & 0 & 1 & 2 \\
\hline & Acompanhamento dos resultados & 13 & $\begin{array}{l}\text { Acompanhamento dos resultados ulteriores } \\
\text { intermediários }\end{array}$ & 0 & 1 & 2 \\
\hline & ulteriores intermediários e finais. & 14 & $\begin{array}{l}\text { Acompanhamento dos resultados ulteriores } \\
\text { finais }\end{array}$ & 0 & 1 & 2 \\
\hline
\end{tabular}

QUADRO 3.20 - Características a serem avaliadas no sistema de monitoramento implementado pela empresa

Fonte: Elaborado pelo Autor (2007)

Como a condição em que cada característica/prática pode ocorrer ou ser constatada num caso real pode variar. No presente trabalho, admite-se que a condição verificada pode ser enquadrada por uma escala de 3 níveis. Nesta escala, 
os valores 0,1 ou 2 presentes na última coluna do Quadro 3.20 são atribuídos conforme os seguintes critérios:

- 0 - característica não é constatada ou a prática não é adotada;

- 1 - característica se faz parcialmente presente ou a há parcial aderência à prática;

- 2 - característica se faz totalmente presente ou a há plena aderência à prática.

\subsubsection{Capacidade do sistema de monitoramento existente em realizar ajustes e correções}

O monitoramento das interações entre uma empresa ou entidade de SRU e seus clientes pode identificar a ocorrência de resultados ulteriores intermediários insatisfatórios que apontarão a necessidade de ajustes e correções na continuidade do processo de entrega do serviço. A capacidade do sistema de monitoramento existente de promover ajustes e correções requeridos pode ser verificada considerando as características e práticas específicas referentes às atividades abrangidas pela fase 2 descritas no Quadro 3.20.

\subsubsection{Táticas que estimulam o envolvimento e a participação dos clientes}

Como já exposto anteriormente, num SRU, os resultados ulteriores buscados dependem dos clientes participarem e se empenharem nas atividades realizadas durante a entrega do serviço. Logo, a empresa deverá empregar táticas que estimulem o seu envolvimento e participação no processo.

À luz da revisão bibliográfica exposta na seção 3.3, as várias táticas voltadas para este fim sugeridas por diferentes autores, são descritas a seguir: 
- implementação de programas de treinamento e orientação (aulas formais, folhetos, placas de orientação, etc.) dos clientes (HOFFMAN e BATESON, 2003; LOVELOCK e WRIGHT, 2002; ZEITHAML e BITNER, 2003) e disponibilização de informações relevantes para a adequada participação do cliente no processo de entrega do serviço (LOVELOCK,1995);

- realização de atividades como festas, excursões e passeios para promover maior socialização entre os clientes (ZEITHAML e BITNER, 2003);

- premiação, concessão de descontos ou outro meio de recompensa para incentivar maior participação do cliente no processo (LENGNICK-HALL, 1996);

- imposição de regras de conduta a serem seguidas pelos clientes durante a entrega do serviço, recompensando os clientes pelo bom comportamento ou punindo-os pelo oposto (HOFFMAN e BATESON, 2003; LOVELOCK e WRIGHT, 2002; ZEITHAML e BITNER, 2003);

- fornecimento de suporte ao cliente durante a realização das atividades, por meio de orientações, esclarecimento de dúvidas e demais atividades que estimulem sua participação (ZEITHAML e BITNER, 2003);

- envolvimento do cliente no planejamento, para obter subsídios à definição das atividades que irão compor o processo de serviço (WIKTRÖM, 1996);

- informação antecipada sobre o processo de entrega do serviço, como um meio de tornar a clientela ciente de seu papel de co-produção e de usuária, conscientizando a clientela sobre importância da correta execução do serviço sob a sua responsabilidade (ZEITHAML e BITNER, 2003). 


\subsubsection{Desempenho do serviço}

Este trabalho propõe-se a focalizar o desempenho obtido pelo serviço por meio de seus produtos e resultados, tal como indicado na Figura 3.24. Isso implica nos indicadores de desempenho terem de contemplar os três papéis que o cliente assume na saída do processo de transformação, quais sejam: como comprador, como usuário e como produto. Vale ressaltar que, como produto, o cliente depende da execução de seus papéis enquanto comprador e usuário. Isso decorre do fato de que o cliente como produto do serviço depende dele mesmo se interessar em realizar o serviço e executá-lo de modo adequado.

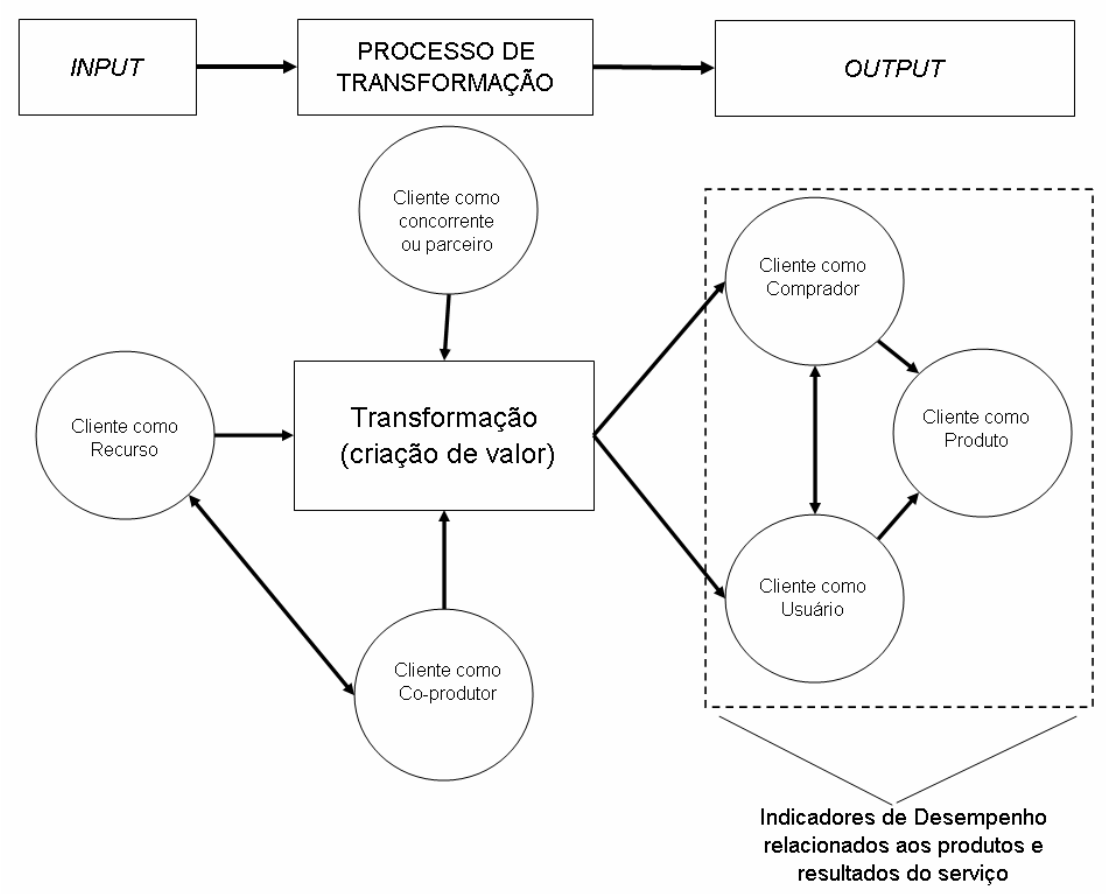

FIGURA 3.24 - Medição de desempenho no contexto dos diferentes papéis do cliente

Fonte: Elaborada pelo Autor (2007) 
O presente estudo adota três indicadores para a avaliação do desempenho nos serviços analisados: eficácia, freqüência e taxa de retenção. Estes foram escolhidos por três motivos principais:

- simplicidade de compreensão e facilidade de obtenção em organizações de serviços;

- cada um deles está relacionado com um dos três papéis assumidos pelo cliente na saída do processo de transformação. A Figura 3.25 relaciona estes indicadores com o papel a que se refere;

- os três indicadores relacionam-se indiretamente com o critério de desempenho qualidade dos serviços prestados e o um indicador se refere diretamente ao critério de desempenho eficácia.

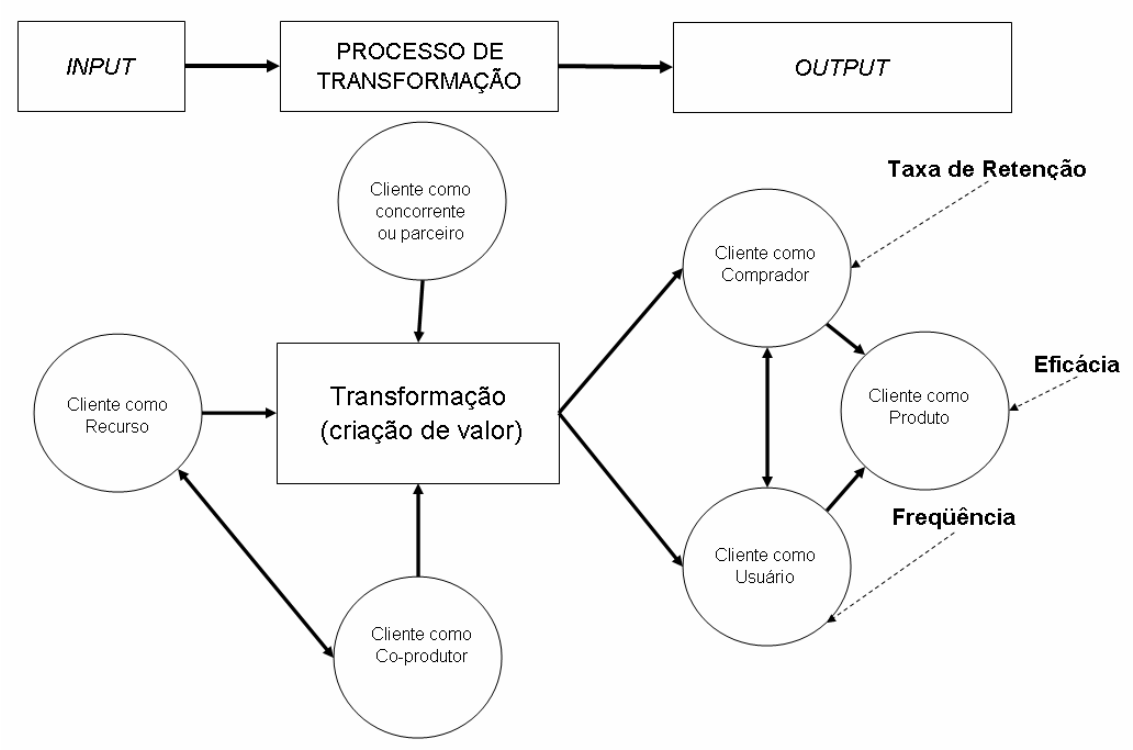

FIGURA 3.25 - Indicadores para medição de desempenho de serviços

Fonte: Pesquisa do Autor (2007)

Este trabalho entende como eficácia a relação entre a quantidade de clientes que atingiram os resultados ulteriores almejados sobre a quantidade total de clientes que objetivaram estes resultados ulteriores em um dado período de tempo. Estes dados são coletados considerando o período de tempo em que as atividades do 
serviço demandam para apresentarem os primeiros resultados ulteriores efetivos ${ }^{14}$. A taxa de retenção é calculada mediante a relação dos clientes que permaneceram no serviço sobre os clientes inicialmente considerados no período de tempo que foi utilizado para a determinação da eficácia do serviço.

\subsubsection{Trade-off entre eficiência e eficácia}

Como mencionado anteriormente, a eficiência está associada ao consumo de recursos. Nos serviços analisados neste trabalho, o cliente torna-se um recurso que é transformado e, ao mesmo tempo, atua como co-produtor e como concorrente ou parceiro de outros. Portanto, a eficiência depende da correta participação e do envolvimento do cliente no processo. Além disso, os SRUs demandam um sistema de monitoramento e controle que, por sua vez, impetra a necessidade de estruturar recursos (pessoas, equipamentos, instalações, etc.) para monitorar os efeitos pretendidos e as variáveis externas. Esses aspectos fazem com que a busca pela eficiência seja um objetivo bastante desafiador nos SRUs.

A eficácia de um sistema pode ser verificada se este realiza aquilo a que se propôs. Reiterando a discussão anterior, a adequada participação do cliente no processo é necessária para a obtenção dos efeitos pretendidos pelo serviço. Para que essa participação ocorra de modo apropriado, é preciso haver um monitoramento das variáveis externas sob controle do cliente. Além disso, esforços devem ser despendidos para a sua orientação, educação e treinamento. Essas atividades demandam recursos ao prestador do serviço. Ao adentrar na análise de eficiência e eficácia, pode-se facilmente identificar um trade-off entre a eficiência, que busca a minimização dos recursos a serem utilizados, e a eficácia, que depende destes recursos para se concretizar. $O$ tratamento desse trade-off torna-se mais premente nos SRUs, na medida em que tais serviços necessitam de recursos

\footnotetext{
${ }^{14}$ Nos cursos preparatórios e de formação educacional e profissional este tempo corresponde ao término do curso, onde o aluno já tomou conhecimento de todo o conteúdo do curso. Nas atividades de musculação este tempo normalmente é de três meses.
} 
adicionais para realizar o monitoramento das atividades realizadas pelo cliente, dos efeitos pretendidos e das variáveis externas.

Dessa maneira, torna-se relevante entender como os SRUs compatibilizam a busca da eficácia com a necessidade de assegurar também a eficiência.

\subsubsection{As Proposições de pesquisa e o Framework Teórico}

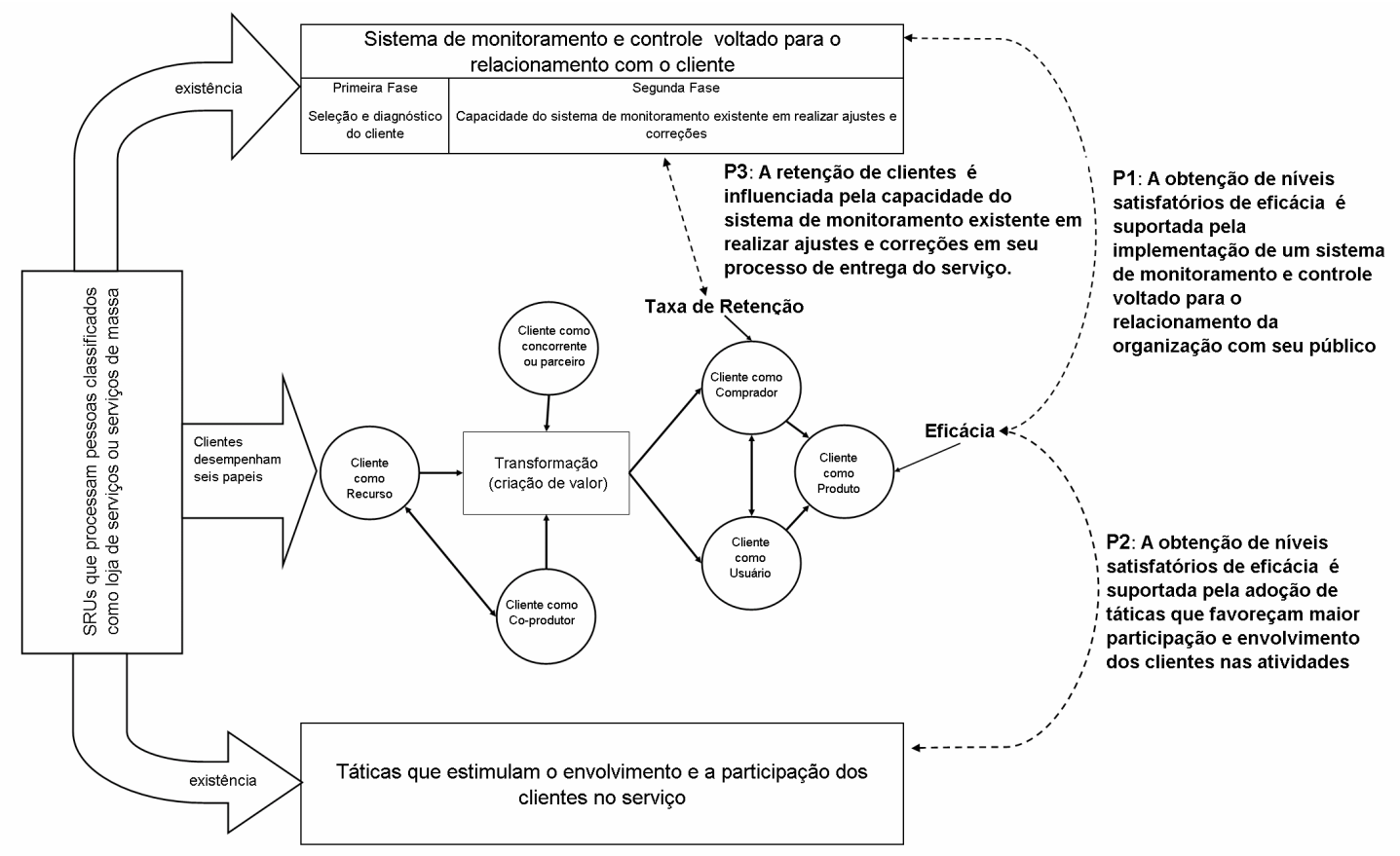

FIGURA 3.26 - O relacionamento das proposições de pesquisa com elementos do framework teórico proposto

Fonte: Pesquisa do Autor (2007)

Consolidando o que foi discutido nesta seção, entende-se que o framework teórico que será considerado para a verificação das três proposições de pesquisa delineadas na seção 2.4 é composto de três elementos fundamentais. O primeiro elemento refere-se ao sistema de monitoramento e controle voltado para o relacionamento com cliente. Este sistema, por sua vez, admite que o monitoramento 
pode ser decomposto em duas fases. A cada fase são atribuídas algumas características e práticas que podem ser avaliadas em cada caso observado na pesquisa de campo. O segundo elemento refere-se à adoção de táticas que estimulam o envolvimento e a participação dos clientes no serviço. A ocorrência de cada tática pode também ser verificada em cada caso observado na pesquisa de campo. Finalmente, o terceiro elemento é constituído de indicadores para a medição de desempenho. No framework teórico, o terceiro elemento é o que possibilita avaliar a influência dos dois elementos anteriores no desempenho do serviço, para isso, foram selecionados os indicadores Eficácia e Taxa de Retenção. As três proposições de pesquisa que direcionam o presente trabalho podem ser verificadas pela avaliação destes três elementos nos casos investigados em campo. O método utilizado na pesquisa para a verificação das proposições está detalhado no capítulo 4. A Figura 3.26 contextualiza o relacionamento das três proposições de pesquisa com os principais elementos que compõem o framework teórico. 


\section{METODOLOGIA DE PESQUISA}

Este trabalho apresenta o resultado de um estudo científico sobre um tema específico e bem definido, desenvolvido com a motivação de gerar uma real contribuição para a especialidade em questão. Assim sendo, este trabalho busca o objetivo geral de uma tese de doutorado que é o de estabelecer e divulgar um conhecimento científico novo (VIEIRA, 2002).

Handfield e Melnyk (1998) apontam que o conhecimento novo poderá prover um ou mais dos seguintes benefícios:

- um método de organizar e categorizar determinados objetos de estudo;

- uma tipologia para organizar conhecimentos;

- predições para eventos futuros;

- explicações de eventos passados;

- certa compreensão sobre as causas de eventos, em alguns casos;

- condições potenciais para controlar os eventos.

Apenas a criação de conhecimento não é suficiente para se obter sucesso. Para que uma pesquisa seja bem-sucedida sua proposta deve ser aceita por outros pesquisadores bem como aplicada por profissionais no campo. Para conseguir esse feito, ela deve melhorar a compreensão do objeto estudado, além de alcançar um ou mais dos seis objetivos acima listados. Finalmente, deve ser capaz de passar pelo teste do mundo real. Uma idéia não experimentada é, simplesmente, uma visão do pesquisador formatada de modo bem civilizado, nada mais do que isto (HANDFIELD e MELNYK, 1998).

Entretanto, a criação de conhecimento parte e se apóia em uma dada teoria. Portanto, é necessário discutir, mesmo que num nível superficial, como as teorias são desenvolvidas. Nessa direção, Handfield e Melnyk (1998) propõem uma estrutura conceitual para se entender os diferentes estágios do desenvolvimento de uma teoria voltada para o gerenciamento de operações, conforme apresentada no Quadro 4.1. 


\begin{tabular}{|c|c|c|c|c|}
\hline $\begin{array}{c}\text { Estágio } \\
\text { (Propósito) }\end{array}$ & Questão de pesquisa & Estrutura de pesquisa & $\begin{array}{l}\text { Exemplos de técnicas } \\
\text { de coleta de dados }\end{array}$ & $\begin{array}{c}\text { Exemplos de técnicas } \\
\text { para análise dos } \\
\text { dados }\end{array}$ \\
\hline $\begin{array}{l}\text { 1a. Descoberta } \\
\text { Descobrir áreas para } \\
\text { pesquisa e } \\
\text { desenvolvimento } \\
\text { teórico }\end{array}$ & $\begin{array}{l}\text { O que está acontecendo } \\
\text { aqui? } \\
\text { Existe alguma coisa } \\
\text { suficientemente } \\
\text { interessante para justificar } \\
\text { uma pesquisa? }\end{array}$ & $\begin{array}{l}\text { Estudo de caso } \\
\text { aprofundado } \\
\text { Estudo de campo não } \\
\text { focalizado longitudinal }\end{array}$ & $\begin{array}{l}\text { Observação } \\
\text { Entrevistas } \\
\text { Documentos } \\
\text { Entrevista de pessoas } \\
\text { selecionadas }\end{array}$ & $\begin{array}{l}\text { Insight } \\
\text { Categorização } \\
\text { Opinião de especialistas } \\
\text { Descrições }\end{array}$ \\
\hline $\begin{array}{l}\text { 1b. Descrição } \\
\text { Explorar o território }\end{array}$ & $\begin{array}{l}\text { O que está aí? } \\
\text { Quais são as variáveis } \\
\text { chaves? } \\
\text { O que está acontecendo? }\end{array}$ & $\begin{array}{l}\text { Estudo de caso } \\
\text { aprofundado } \\
\text { Estudo de campo não } \\
\text { focalizado longitudinal }\end{array}$ & $\begin{array}{l}\text { Observação, Entrevistas } \\
\text { (grupo ou individual) } \\
\text { Documentos } \\
\text { Entrevista de pessoas } \\
\text { selecionadas } \\
\text { Técnica do incidente crítico }\end{array}$ & $\begin{array}{l}\text { Insight } \\
\text { Categorização } \\
\text { Opinião de especialistas } \\
\text { Descrições } \\
\text { Análise de conteúdo } \\
\end{array}$ \\
\hline $\begin{array}{l}\text { 2. Mapeamento } \\
\text { Identificar/descrever } \\
\text { as variáveis chaves } \\
\text { Desenhar mapas do } \\
\text { território }\end{array}$ & $\begin{array}{l}\text { Quais são as variáveis } \\
\text { chaves? } \\
\text { Quais são os temas, } \\
\text { padrões ou categorias mais } \\
\text { salientes /relevantes? }\end{array}$ & $\begin{array}{l}\text { Poucos estudos de caso } \\
\text { focalizados } \\
\text { Estudos de casos } \\
\text { aprofundados } \\
\text { Múltiplos estudos de caso } \\
\text { Estudos de caso das } \\
\text { melhores práticas }\end{array}$ & $\begin{array}{l}\text { Observação } \\
\text { Entrevistas aprofundadas } \\
\text { Diários de questionários de } \\
\text { pesquisa } \\
\text { História } \\
\text { Medidas não obstrutivas }\end{array}$ & $\begin{array}{l}\text { Protocolo verbal } \\
\text { Análise } \\
\text { Mapas cognitivos } \\
\text { Análise de conteúdo } \\
\text { Matriz de efeitos } \\
\text { Repertory grid technique }\end{array}$ \\
\hline $\begin{array}{l}\text { 3. Construção de } \\
\text { relacionamentos } \\
\text { Melhorar os mapas } \\
\text { através da } \\
\text { identificação de } \\
\text { relações entre as } \\
\text { variáveis } \\
\text { Identificar o por que } \\
\text { destas relações }\end{array}$ & $\begin{array}{l}\text { Quais são os padrões ou as } \\
\text { ligações entre as variáveis? } \\
\text { Pode-se identificar uma } \\
\text { ordem de relacionamento? } \\
\text { Por que estas relações } \\
\text { existem? }\end{array}$ & $\begin{array}{l}\text { Poucos estudos de caso } \\
\text { focalizados } \\
\text { Estudos de caso } \\
\text { aprofundados. } \\
\text { Estudos de caso em vários } \\
\text { locais } \\
\text { Estudo de caso das } \\
\text { melhores práticas }\end{array}$ & $\begin{array}{l}\text { Observação } \\
\text { Entrevista de profundidade } \\
\text { Diários de questionários de } \\
\text { pesquisa } \\
\text { História } \\
\text { Medidas não obstrutivas }\end{array}$ & $\begin{array}{l}\text { Protocolo verbal } \\
\text { Análise } \\
\text { Mapas cognitivos } \\
\text { Repertory grid technique } \\
\text { Matriz de efeitos } \\
\text { Análise de conteúdo } \\
\text { Análise de fator } \\
\text { Multidimensional scaling } \\
\text { Análise de correlação } \\
\text { Estatística não-paramétrica }\end{array}$ \\
\hline $\begin{array}{l}\text { 4. Validação da } \\
\text { teoria } \\
\text { Testar as teorias } \\
\text { desenvolvidas nos } \\
\text { estágios anteriores } \\
\text { Predizer resultados } \\
\text { futuros }\end{array}$ & $\begin{array}{l}\text { As teorias que foram } \\
\text { geradas são capazes de } \\
\text { sobreviver a testes } \\
\text { empíricos? } \\
\text { Foi obtido o comportamento } \\
\text { que estava previsto pela } \\
\text { teoria ou foi observado um } \\
\text { comportamento não } \\
\text { esperado? }\end{array}$ & $\begin{array}{l}\text { Experimento } \\
\text { Quase-experimento } \\
\text { Ampla amostra da } \\
\text { população }\end{array}$ & $\begin{array}{l}\text { Entrevistas estruturadas } \\
\text { Documentos } \\
\text { Questionários com } \\
\text { questões abertas e } \\
\text { fechadas } \\
\text { Experimentos de laboratório } \\
\text { Experimento de campo } \\
\text { Quase-experimentos } \\
\text { Surveys }\end{array}$ & $\begin{array}{l}\text { Triangulação } \\
\text { Análise de variância } \\
\text { Regressão } \\
\\
\text { Análise } \\
\text { Path analysis } \\
\text { Survival analysis } \\
\text { Procedimentos de múltiplas } \\
\text { comparações } \\
\text { Estatística não-paramétrica }\end{array}$ \\
\hline $\begin{array}{l}\text { 5. Refinamento e } \\
\text { ampliação da teoria } \\
\text { Expandir o mapa da } \\
\text { teoria }\end{array}$ & $\begin{array}{l}\text { Avaliar quão aplicáveis e } \\
\text { generalizáveis são as } \\
\text { teorias que foram } \\
\text { desenvolvidas. } \\
\text { Onde as teorias se } \\
\text { aplicam? } \\
\text { Onde as teorias não se } \\
\text { aplicam? }\end{array}$ & $\begin{array}{l}\text { Experimento } \\
\text { Quase-experimento } \\
\text { Ampla amostra da } \\
\text { população }\end{array}$ & $\begin{array}{l}\text { Entrevistas estruturadas } \\
\text { Documentos } \\
\text { Questionários com } \\
\text { questões abertas e } \\
\text { fechadas } \\
\text { Experimentos de laboratório } \\
\text { Experimentos de campos } \\
\text { Quase-experimentos } \\
\text { Surveys } \\
\text { Documentação } \\
\text { Pesquisa de arquivos }\end{array}$ & $\begin{array}{l}\text { Triangulação } \\
\text { Análise de variância } \\
\text { Regressão } \\
\\
\text { Análise } \\
\text { Path analysis } \\
\text { Survival analysis } \\
\text { Procedimentos de múltiplas } \\
\text { comparações } \\
\text { Estatística não-paramétrica } \\
\text { Meta análise }\end{array}$ \\
\hline
\end{tabular}

QUADRO 4.1 - Os diferentes estágios do desenvolvimento de uma teoria

Fonte: Handfield e Melnyk (1998) 


\subsection{POSICIONANDO O TEMA DE PESQUISA NO ESTÁGIO DE DESENVOLVIMENTO DA TEORIA}

A estrutura conceitual proposta por Handfield e Melnyk (1998) torna-se extremamente útil para o presente trabalho, na medida em que pode auxiliar na identificação dos métodos de pesquisa que são mais pertinentes, dado o estágio de desenvolvimento da teoria no qual o tema abordado se enquadra.

Neste contexto, inicialmente, procurou-se situar o tema de pesquisa na estrutura conceitual proposta por Handfield e Melnyk (1998).

A revisão bibliográfica consultada indicou que os SRUs não são tratados de modo diferenciado pela literatura de gerenciamento de serviços. Em um trabalho relativamente recente, Johnston (2005) discute o desenvolvimento da gestão de operações de serviços ao longo dos últimos seis anos e identificou que alguns setores - nos quais os SRUs podem ser incluídos carecem de estudos mais específicos e que temas como eficiência e produtividade merecem ser explorados com mais enfoque.

Acredita-se que o tema SRU em si e a gestão de seu processo visando eficiência e produtividade estão ainda, predominantemente, no estágio incipiente de descoberta/descrição, caminhado para o estágio de mapeamento.

\subsection{A QUESTÃO DE PESQUISA E A ESCOLHA DO MÉTODO}

Uma vez analisado o tema, é importante explorar qual(is) método(s) de pesquisa poderá(ão) ser utilizado(s) face ao objetivo de pesquisa do trabalho. Este consiste em gerar novos conhecimentos para o desenvolvimento da gestão de operações de empresas de SRU que processam pessoas, discutindo e elucidando como um sistema de monitoramento e controle e a adoção de táticas que estimulam 
o envolvimento e a participação dos clientes podem contribuir para que essas empresas obtenham um melhor desempenho.

Uma vez definidos os objetivos propostos pela pesquisa, Yin (2001) sugere que se responda a três pontos que determinam a escolha da estratégia de pesquisa: i) tipo de questão proposta pelo projeto de pesquisa; ii) necessidade de controle do pesquisador sobre os eventos comportamentais; iii) grau de enfoque sobre os acontecimentos contemporâneos. As respostas à aplicação destes pontos para a caracterização do presente trabalho estão organizadas no Quadro 4.2.

\begin{tabular}{|l|l|l|}
\hline Tipo de questão proposta pela Tese & $\begin{array}{l}\text { Necessidade de controle do } \\
\text { pesquisador sobre os eventos } \\
\text { comportamentais }\end{array}$ & $\begin{array}{l}\text { Grau de enfoque sobre os } \\
\text { acontecimentos contemporâneos }\end{array}$ \\
\hline Como e por quê & Não se necessita de controle & $\begin{array}{l}\text { Focaliza as práticas existentes de } \\
\text { monitoramento e as táticas adotadas } \\
\text { para estimular o envolvimento e a } \\
\text { participação dos clientes no serviço }\end{array}$ \\
\hline
\end{tabular}

QUADRO 4.2 - Caracterização da natureza da pesquisa

Fonte: Yin (2001)

Yin (2001) sugere que estudos de caso são particularmente apropriados quando a pergunta de pesquisa concentra-se em "como" e "por quê" os fenômenos observados acontecem, quando não há necessidade de controle sobre o comportamento dos eventos, e quando 0 enfoque estiver em eventos contemporâneos. Sob a ótica dessas considerações e com base no Quadro 4.2, pode-se concluir que o estudo de caso é um método adequado para o presente trabalho.

Mais especificamente, será utilizada a metodologia de múltiplos casos, na medida em que várias empresas ou entidades serão estudadas. A opção por esta abordagem deve-se à pretensão de obter resultados e conclusões que não sejam específicos a um particular caso de SRU e que tenham a possibilidade de serem aproveitados numa gama mais ampla de organizações. Adicionalmente, tal abordagem possibilitará construir um cenário mais amplo da gestão de operações em SRUs, o que em si é um assunto sobre o qual foi constatado que ainda há pouca literatura. 


\subsection{O PROCESSO DE CONDUÇÃO DO ESTUDO DE CASO}

De acordo com Stuart (2002), o processo de condução de um estudo de caso pode ser dividido em cinco fases críticas, as quais são apresentadas nas seções 4.3.1 a 4.3.4.

\subsubsection{Fase 1: Definição da questão de pesquisa}

A primeira fase do processo envolve a definição da questão de pesquisa. Invariavelmente, esta implica em contribuir para o enriquecimento de um corpo de conhecimento e para o desenvolvimento de uma teoria, aspecto que já foi discutido anteriormente neste trabalho.

\subsubsection{Fase 2: Desenvolvimento do instrumento de pesquisa e seleção da amostra}

Uma vez definida a questão de pesquisa, o pesquisador deve desenvolver instrumentos para coletar dados para análise futura. $O$ instrumento de pesquisa utilizado no estudo de caso é o seu protocolo. Seu desenvolvimento envolve muito mais do que a organização das questões que serão abordadas. O protocolo abrange a documentação principal necessária para fornecer aos pesquisadores o enfoque requerido e visa organizar as visitas e assegurar que todas as evidências importantes serão documentadas (STUART, 2002).

As questões presentes no protocolo devem basear-se na proposição de pesquisa estabelecida. Esta prática é fundamental na medida em que torna a coleta de dados mais eficiente. No entanto, o fato de o estudo ser organizado segundo uma estrutura teórica não indica que não exista a possibilidade de alterar ou eliminar 
algumas questões estabelecidas. Isso pode acontecer na fase inicial, ao se realizar as visitas-piloto (STUART, 2002).

Se o estudo de caso é projetado para ser exploratório ou explicativo, ele deve demonstrar o significado e a validade das medidas utilizadas. Segundo Yin (2001), existem quatro dimensões a serem testadas para julgar a qualidade dos trabalhos de pesquisa e, para cada uma delas, algumas táticas podem ser recomendadas. $O$ Quadro 4.3 descreve os testes a serem considerados.

\begin{tabular}{|c|c|c|}
\hline Testes & Tática do estudo de caso & $\begin{array}{l}\text { Fase da pesquisa na qual a } \\
\text { tática deve ser aplicada }\end{array}$ \\
\hline $\begin{array}{l}\text { Validade do constructo } \\
\text { (estabelecer medidas operacionais } \\
\text { corretas para os conceitos que estão } \\
\text { sob estudo) }\end{array}$ & $\begin{array}{ll}\text { - } & \text { utilizar fontes múltiplas de } \\
\text { evidências } \\
\text { - } & \text { estabelecer encadeamento de } \\
\text { evidências } \\
\text { - } \quad \begin{array}{l}\text { revisão do rascunho do } \\
\text { relatório por informantes- } \\
\text { chave }\end{array} \\
\end{array}$ & $\begin{array}{ll}- & \text { coleta de dados } \\
- & \text { coleta de dados } \\
- & \text { composição }\end{array}$ \\
\hline $\begin{array}{l}\text { Validade interna (estabelecer uma } \\
\text { relação causal, por meio da qual são } \\
\text { mostradas certas condições que levam } \\
\text { a outras condições) }\end{array}$ & $\begin{array}{ll}\text { - } & \text { adequação ao padrão } \\
\text { - } & \text { construção da explanação } \\
\text { - } & \text { análise de séries temporais }\end{array}$ & $\begin{array}{ll}- & \text { análise interna } \\
- & \text { análise interna } \\
- & \text { análise interna }\end{array}$ \\
\hline $\begin{array}{l}\text { Validade externa (estabelecer o } \\
\text { domínio no qual as descobertas de um } \\
\text { estudo podem ser generalizadas) }\end{array}$ & $\begin{array}{l}\text { utilizar a lógica de replicação } \\
\text { em estudos de casos } \\
\text { múltiplos }\end{array}$ & - $\quad$ projeto de pesquisa \\
\hline $\begin{array}{l}\text { Confiabilidade (demonstrar que as } \\
\text { atividades de um estudo - como os } \\
\text { procedimentos de coleta de dados - } \\
\text { podem ser repetidas, apresentando os } \\
\text { mesmos resultados) }\end{array}$ & $\begin{array}{ll}- & \text { utilizar protocolo de estudo de } \\
\text { caso } \\
\text { - } \quad \text { desenvolver banco de dados } \\
\text { para o estudo de caso }\end{array}$ & $\begin{array}{ll}- & \text { coleta de dados } \\
- & \text { coleta de dados }\end{array}$ \\
\hline
\end{tabular}

QUADRO 4.3 - Testes e táticas para julgar a qualidade do projeto de pesquisa realizado através de estudo de caso.

Fonte: Baseado em Yin (2001)

\subsubsection{Instrumento de pesquisa}

O instrumento de pesquisa adotado para orientar a coleta de dados na etapa de pesquisa de campo do presente estudo, foi elaborado a partir do framework teórico exposto no Capítulo 3 que pode ser decomposto em três elementos interrelacionados: i) sistema de monitoramento e controle voltado para o relacionamento 
com o cliente; ii) táticas que estimulam o envolvimento e a participação dos clientes; iii) desempenho do serviço. O Quadro 4.4 enumera os pontos contemplados no instrumento de pesquisa, indicando como podem ser caracterizados os elementos a serem focados nos estudos de caso.

\begin{tabular}{|l|l|}
\hline ELEMENTOS & PONTOS PARA ANÁLISE \\
\hline $\begin{array}{l}\text { Sistema de } \\
\text { monitoramento e } \\
\text { medição de } \\
\text { desempenho }\end{array}$ & $\begin{array}{l}\text { Sistema de registro das atividades realizadas pelo cliente no serviço e seus resultados e o } \\
\text { tipo de informação registrada. } \\
\text { Sistema de análise dos registros das atividades realizadas pelo cliente e seus resultados. } \\
\text { Atividades de avaliação realizadas nos episódios não registradas pelo sistema. } \\
\text { Existência de uma rotina de diagnóstico do cliente para definir as atividades que serão } \\
\text { realizadas, ao ingressar no serviço. } \\
\text { Existência de uma rotina de segmentação/seleção/agrupamento dos clientes para o } \\
\text { ingresso no serviço }\end{array}$ \\
\hline $\begin{array}{l}\text { Táticas que } \\
\text { estimulam o } \\
\text { envolvimento e a } \\
\text { participação dos } \\
\text { clientes no serviço }\end{array}$ & $\begin{array}{l}\text { Educação e treinamento para a realização das atividades. } \\
\text { Adoção de atividades que promovem a socialização. } \\
\text { Imposição de regras e condutas envo componto portamento. } \\
\text { Suporte durante a realização das atividades (orientação, esclarecimento de dúvidas e } \\
\text { estímulo à participação). } \\
\text { Envolvimento do cliente no planejamento/definição das atividades que serão realizadas. } \\
\text { Conscientização da importância do adequado cumprimento das atividades sob a } \\
\text { responsabilidade do cliente. }\end{array}$ \\
\hline
\end{tabular}

QUADRO 4.4 - Pontos para análise considerados na pesquisa.

Fonte: Elaborado pelo autor (2007)

A partir destes pontos de análise, foi montado o roteiro de entrevista, apresentado no Anexo A, no qual o pesquisador se apoiou para conduzir a realização dos estudos de casos múltiplos.

\subsubsection{Associação lógica entre os dados coletados e a proposição de pesquisa}

Os dados coletados servirão para descrever e entender o sistema de monitoramento e controle existente. Mais especificamente, eles possibilitarão estimar o grau de aplicação das características e práticas desejáveis para esse sistema, conforme o modelo proposto no framework teórico exposto na seção 3.5.1. As características e práticas referentes à segunda fase do modelo proposto no framework teórico exposto na seção 3.5.1.1, permitirão ainda estimar a capacidade 
do sistema de monitoramento e controle de realizar ajustes e correções em seu processo de entrega do serviço. Os dados também servirão para avaliar o grau de adoção de táticas que estimulem o envolvimento e a participação dos clientes.

No que tange à medição de desempenho, serão coletados dados referentes à eficácia, taxa de retenção e freqüência nos casos analisados.

Com base nesses dados torna-se possível verificar as três proposições de pesquisa levantadas. Nesta direção, para cada proposição será descrito a seguir o meio a ser considerado para sua verificação.

Como mencionado anteriormente, a primeira proposição $\left(P_{1}\right)$ refere-se à afirmação de que a obtenção de níveis satisfatórios de eficácia em empresas de SRU que processam pessoas é suportada pela implementação de um sistema de monitoramento e controle voltado para o relacionamento da organização com o seu público. A sua verificação será realizada mediante comparação de duas variáveis. A primeira refere-se ao "grau de aplicação das características e práticas desejáveis para um sistema de monitoramento e controle" (em \%) e a segunda refere-se ao "percentual de eficácia" (em \%) obtido em cada caso. O "grau de aplicação das características e práticas desejáveis para um sistema de monitoramento e controle" é calculado mediante o somatório dos valores atribuídos a cada uma das 14 características/práticas avaliadas na pesquisa de campo sobre o valor máximo possível de 28 pontos e o Quadro 4.5 ilustra este procedimento de cálculo. Esta proposição pode ser aceita caso seja verificado que as empresas que apresentam um maior grau de aplicação das características e práticas desejáveis para um sistema de monitoramento e controle alcançam maior eficácia, e inversamente, as empresas que aplicam em menor grau um sistema de monitoramento e controle revelam eficácia relativamente menor. De um modo pictórico, para a aceitação da proposição, as duas variáveis devem se comportar como ilustrado no Gráfico 4.1. 


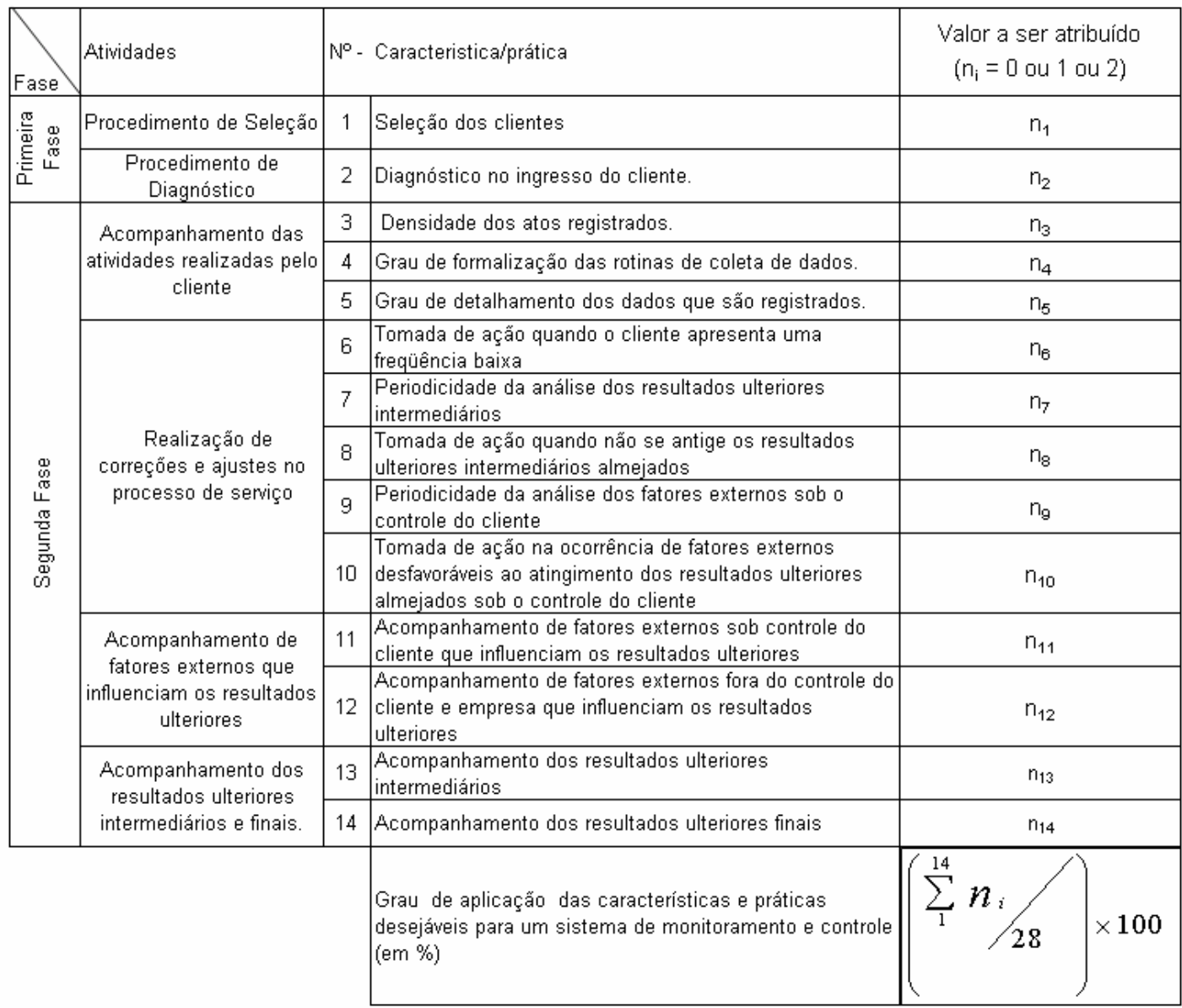

Valores 0, 1 ou 2 presentes na última coluna são atribuídos conforme os seguintes critérios:

- $\quad 0$ - característica nẫo é constatada ou a prática nẫo é adotada;

- $\quad 1$ - característica se faz parcialmente presente ou a há parcial aderência à prática;

- $\quad 2$ - característica se faz totalmente presente ou a há plena aderência à prática.

QUADRO 4.5 - Verificação da proposição por meio gráfico

Fonte: Pesquisa do Autor (2007)

Como exposto anteriormente, a segunda proposição $\left(P_{2}\right)$ refere-se à afirmação de que a obtenção de níveis satisfatórios de eficácia em empresas de SRU que processam pessoas é suportada pela adoção de táticas que favoreçam mais participação e envolvimento dos clientes nas atividades. A sua verificação também será realizada mediante comparação de duas variáveis. A primeira refere-se ao "grau de adoção de táticas que estimulam o envolvimento e a participação dos clientes" (em \%) e a segunda refere-se ao "percentual de eficácia" (em \%) obtido em 
cada caso. O "grau de adoção de táticas que estimulam o envolvimento e a participação dos clientes" é calculado mediante a contabilização das táticas que são adotadas pela empresa sobre a quantidade máxima de táticas que uma empresa poderá adotar (7 táticas). Esta proposição pode ser aceita caso seja verificado que as empresas que apresentam um maior grau de adoção de táticas que estimulam o envolvimento e a participação dos clientes alcançam maior eficácia e, inversamente, as empresas que recorrem em menor grau a tais táticas revelam eficácia relativamente menor. De modo semelhante à verificação da primeira proposição, para a aceitação da segunda proposição, as duas variáveis devem se comportar como ilustrado no Gráfico 4.1.

Finalmente, a terceira proposição $\left(\mathrm{P}_{3}\right)$, refere-se à afirmação de que a retenção de clientes em empresas de SRU que processam pessoas é influenciada pela capacidade do sistema de monitoramento e controle existente em realizar ajustes e correções em seu processo de entrega do serviço. Do mesmo modo que ocorreu nas duas primeiras proposições, a verificação da terceira proposição será realizada mediante comparação de duas variáveis. A primeira refere-se à "capacidade do sistema de monitoramento e controle realizar ajustes e correções em seu processo de entrega do serviço" (em \%) e a segunda refere-se ao "percentual de taxa de retenção" (em \%) alcançado em cada caso. Esta proposição pode ser aceita caso seja verificado que as empresas que apresentam maior capacidade de realizar ajustes e correções em seu processo de entrega do serviço, atingem maior taxa de retenção e, inversamente, as empresas que têm menor capacidade de promover tais ajustes e correções revelam taxa de retenção relativamente menor. De modo semelhante à primeira e a segunda proposições, as duas variáveis devem se comportar como ilustrado no Gráfico 4.1, para a aceitação da terceira proposição. 


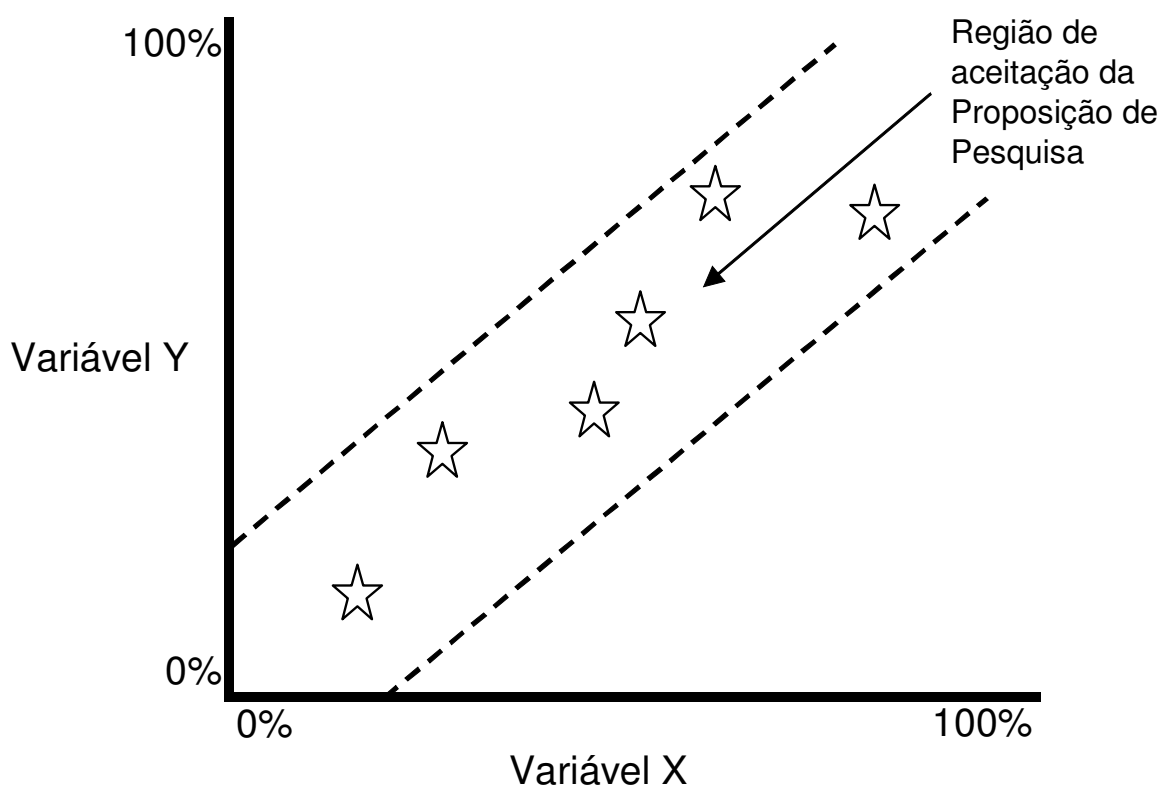

FIGURA 4.1 - Verificação da proposição de pesquisa por meio gráfico Fonte: Pesquisa do Autor (2007)

\subsubsection{A escolha dos casos/amostra}

A quantidade de unidades analisadas se relaciona diretamente com a validade externa da pesquisa e com o estágio de desenvolvimento da teoria.

A adoção de múltiplos casos (entre quatro e dez unidades de análise) é apropriada quando existir um pouco de conhecimento sobre o fenômeno que está sendo analisado, mas este ainda é, no seu todo, desconhecido (MEREDITH, 1998). O tema abordado neste trabalho situa-se neste estágio. Além disso, como colocado por Voss; Tsikriktsis e Frohlic (2002), a adoção de múltiplos casos pode tanto aumentar a validade externa como reduzir as conseqüências de erros que sejam cometidos pelo pesquisador.

O desenvolvimento do presente trabalho apoiou-se no estudo de um conjunto constituído de seis casos, em diferentes organizações. No sentido de permitir uma 
melhor confrontação dos dados coletados, foram pesquisadas empresas de três tipos de SRUs. Dois destes tipos têm fins lucrativos enquanto um tipo não visa ao lucro. Para todos os casos, foram feitos estudos retrospectivos. A composição da amostra estudada apresenta o seguinte perfil:

- duas academias de ginástica (com fim lucrativo);

- dois cursos preparatórios para concursos (com fim lucrativo);

- dois cursos de aperfeiçoamento profissional que visam à inserção no mundo do trabalho (sem fim lucrativo).

A adoção dessa amostra tornou possível também a comparação entre empresas que realizam SRUs do mesmo tipo.

\subsubsection{Fase 3: Coleta de dados}

Nos estudos de caso, os "dados" são freqüentemente as anotações ou gravações das entrevistas, documentos que a empresa aceita fornecer e as próprias observações do entrevistador. Como o pesquisador deve determinar as verdadeiras relações causais, a construção de uma relação de confiança perante o entrevistado é muito importante para o sucesso da pesquisa. Os pesquisadores, algumas vezes, se deparam com um dilema. Por um lado, existe uma limitação de tempo para construir uma relação de confiança entre o entrevistador e o entrevistado, a qual é importante para se obter uma melhor qualidade de informações. Por outro lado, ao se aumentar a confiança entre as duas partes, pode ocorrer, do entrevistador tender a ser visto como um "consultor" pelo entrevistado, uma função que pode ser conflitante com o papel de pesquisador. Algumas vezes, o fornecimento de uma opinião ou conselho útil é necessário para se obter mais aceitação e confiança. De qualquer forma, o pesquisador deve sempre refletir sobre o protocolo de pesquisa utilizado e sobre sua razão de estar ali. Alguns desenvolvem certa habilidade em explicar o problema de pesquisa de tal modo que faça sentido para os entrevistados. Freqüentemente, alguns entrevistados vêem a entrevista como oportunidade de 
refletirem sobre os tópicos abordados, conseguindo, assim, aumentar e melhorar a compreensão de seus processos. Além das entrevistas, registros de arquivos, e documentos internos da organização, múltiplas entrevistas e entrevistadores devem ser utilizados, quando possível. Esse procedimento possibilitará um retrato mais completo do ambiente estudado. Essa abordagem multifacetada se assemelha à estratégia de triangulação utilizada nas pesquisas etnográficas e pode ser útil para uma melhor compreensão da realidade estudada (STUART, 2002).

Para garantir a boa qualidade da pesquisa e considerando os aspectos relacionados acima, várias das táticas sugeridas por Yin (2001), apresentadas no Quadro 4.3, foram empregadas nas atividades de coleta de dados. As fontes de evidência utilizadas são enumeradas a seguir:

- consideração de várias fontes de evidência, tais como atas, memorandos, livros, folhetos informativos, relatórios internos e relatório de exercício;

- entrevistas: foram entrevistados os responsáveis pela supervisão dos serviços analisados. A escolha desses entrevistados se deu pela indicação do gestor do serviço, ao conhecer o tema e/ou questionário do roteiro de pesquisa. O questionário elaborado para direcionar as entrevistas é do tipo semi-estruturado (Anexo A). A maioria das entrevistas foi gravada. Seguiu-se a orientação de Gil (1999), estruturando a entrevista por pautas, para permitir seu desenvolvimento de modo mais sistematizado (GIL, 1999);

- observação direta: em algumas empresas, informações também foram obtidas por intermédio de reuniões e visitação das instalações.

\subsubsection{Fases 4 e 5: Análise dos dados e divulgação}

O desafio do pesquisador não é só observar, escutar e registrar os dados de um modo sistemático. Para que um trabalho de pesquisa chegue a uma conclusão 
válida é fundamental analisá-los e conseguir interpretar o que os indivíduos abordados estão tentando dizer. A interpretação de informações qualitativas é, em grande parte, um desafio para o pesquisador. Este deve encontrar respostas para questões como as seguintes: Os padrões são evidentes? Existe um modelo conceitual que ajuda a explicar o padrão de comportamento observado? Existem modelos teóricos que explicam razoavelmente o padrão de comportamento observado em todos os casos? Se não, que elemento teórico precisaria ser adicionado aos modelos existentes? (STUART, 2002).

A descrição dos casos e suas respectivas análises e conclusões seguem nos Capítulos 5, 6 e 7, respectivamente. 


\section{DESCRIÇÃO DOS CASOS}

Neste capítulo são relatados os resultados encontrados em seis estudos de casos conduzidos em organizações de SRUs. Os casos são apresentados e analisados de modo individualizado.

\subsection{CASO 1: ACADEMIA DE GINÁSTICA - ATIVIDADES DE MUSCULAÇÃO (AC1)}

\subsubsection{Caracterização da empresa}

Antes da caracterização, é necessário entender um pouco melhor no que consistem as academias de ginástica.

Entende-se como academia de ginástica o lugar, ou a escola, onde se ministra a instrução física. É um lugar de aprendizado, de transmissão de técnicas de ginástica ${ }^{15}$ por parte de quem as detém e de aquisição por parte de quem deseja obtê-las. O aparecimento de academias de ginástica que combinam exercícios físicos com o prazer da música deu-se por volta de 1970. Nessa época, eram empresas pequenas instaladas em uma sala ou em casas. Já a partir de 1982, com o interesse despertado pelos programas aeróbicos, uma nova geração de empresários resolveu investir na construção de empresas que são verdadeiros centros de atividade física. Iniciaram-se, assim, as grandes academias de ginástica, nos grandes centros urbanos, com a preocupação de oferecer um espaço amplo e as últimas novidades em atividade física aos seus usuários. Estima-se que existam mais de 18.000 academias de ginástica espalhadas por todo Brasil (ZANETTE, 2003).

\footnotetext{
${ }^{15}$ Ginástica é o conjunto de exercícios físicos ritmados e sistematizados por meio de movimentos repetidos, para que sejam atingidos os ideais propostos tais como emagrecimento, hipertrofia geral,definição muscular, etc.
} 
As academias de ginástica oferecem uma ampla variedade de serviços, alguns deles são exemplificados no Quadro 5.1.

\begin{tabular}{|l|l|}
\hline \multicolumn{1}{|c|}{ Atividades/serviços } & \multicolumn{1}{c|}{ Exemplos } \\
\hline Atividades físicas/fitness & $\begin{array}{l}\text { Ginásticas e suas variações: step, street, condicionamento físico, musculação, } \\
\text { aerofunk, aeroboxe, alongamento, abdominais, bike class ou spinning, circuit } \\
\text { training, body pump, lift training. } \\
\text { Danças: balé ou clássico, de salão, ventre, jazz, sapateado, flamenco, entre } \\
\text { outras. } \\
\text { Lutas: judô, caratê, defesa pessoal, boxe, capoeira, jiu-jitsu }\end{array}$ \\
\hline Atividades físicas na água & Natação; hidroginástica; lazer windsurf; mergulho. \\
\hline Esportes & Basquetebol; handebol; voleibol; futebol; tênis e squash. \\
\hline Saúde & $\begin{array}{l}\text { Avaliação física; nutrição; fisioterapia/reabilitação; medicina estética; psicologia } \\
\text { desportiva. }\end{array}$ \\
\hline Cultura, recreação e lazer & $\begin{array}{l}\text { Teatro e cinema; cursos e palestras; eventos esportivos oficiais e internos; } \\
\text { turismo. }\end{array}$ \\
\hline Outros serviços & $\begin{array}{l}\text { Sauna; vendas de produtos esportivos, vitaminas e suplementos alimentares; } \\
\text { espaço lúdico de entretenimento de crianças; serviços de lavanderia, tinturaria, } \\
\text { fax, sapataria, cabeleireiro, barbeiro, locação de vídeo, berçário. }\end{array}$ \\
\hline
\end{tabular}

QUADRO 5.1 - Serviços oferecidos por academias de ginástica

Fonte: Baseado em Nobre (2000)

Dentre os serviços listados, a academia pesquisada oferece serviços de atividades físicas/fitness: musculação, ginástica localizada, step, jump, pump, axé, capoeira e fisioterapia. Atende a cerca de 300 alunos, mas apresenta baixa ocupação nos horários fora de pico (Gráfico 5.1). 


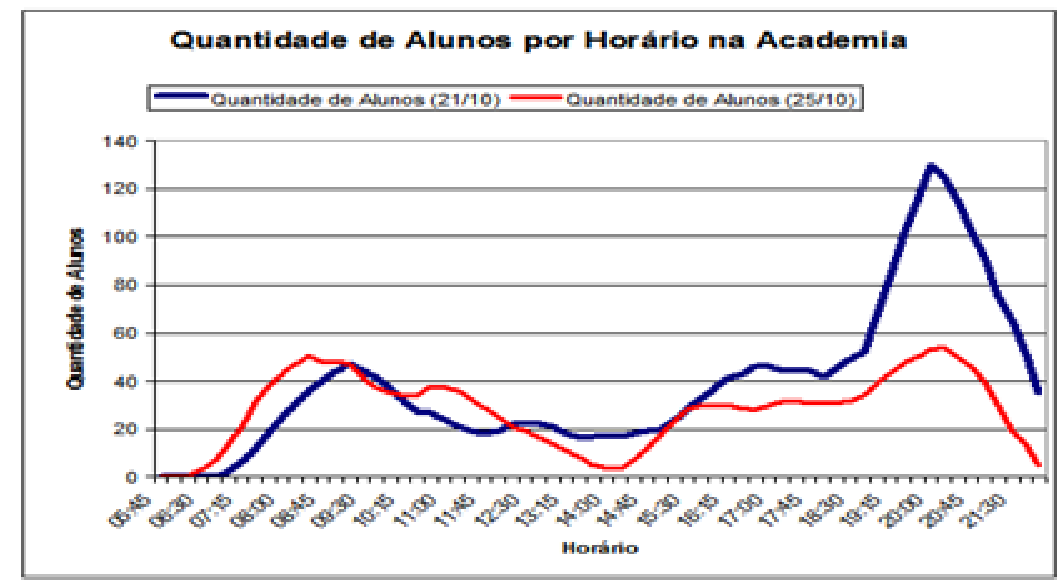

GRÁFICO 5.1 - Quantidade de alunos por horário em dois dias da semana - terçafeira e sexta-feira - estimando-se um tempo de permanência de 75 minutos no local

Fonte: Pesquisa do autor, 2007.

OBS: O dia 21/10 foi numa sexta-feira e o dia 25/10 numa terça-feira.

\subsubsection{Coleta de dados}

Dada a grande variedade de serviços oferecidos por esta academia, este estudo de caso foi restrito às atividades de musculação. Os dados foram coletados por meio de entrevistas com o sócio-diretor da academia. Foram consultados também relatórios e demais documentos utilizados pela academia.

\subsubsection{Processo de entrega do serviço}

Os serviços de musculação oferecidos forman uma seqüência de atividades. Essa seqüência é constituída de dois tipos de episódios. O primeiro tipo ocorre logo 
após a compra do serviço ${ }^{16}$ e consiste na avaliação física e fisioterápica. Implica, primeiramente, na identificação dos objetivos procurados com a ginástica. Alguns desses objetivos podem ser: hipertrofia geral intensa, reabilitação muscular, definição muscular, relaxamento, alívio de dores, flexibilidade, emagrecimento, condicionamento físico e correção postural. Uma vez definido o programa de atividades físicas a ser seguido, passa-se ao segundo tipo de episódio que consiste na execução da ficha de treinamento estabelecida na avaliação inicial. De três em três meses, a academia solicita aos seus clientes que realizem uma reavaliação física e fisioterápica, começando uma nova seqüência de serviços de musculação. Como uma estratégia para incentivar os alunos a fazerem essa reavaliação, a ficha de treinamento só pode ser alterada após aquela providência ter sido tomada. $\mathrm{Na}$ reavaliação, é verificado o grau de atendimento dos objetivos estabelecidos na avaliação anterior. Em caso de não-atendimento dos objetivos, o avaliador, junto com o aluno, verifica as possíveis causas. Normalmente, discutem-se aspectos como freqüência às aulas, cumprimento das atividades previstas na ficha e hábitos de alimentação.

\subsubsection{Sistema de monitoramento e controle dos clientes}

\subsubsection{Primeira fase - Procedimentos de seleção e de diagnóstico}

Existe um procedimento de seleção dos clientes. Durante as primeiras avaliações física e fisioterápica são tomadas algumas medidas e feitas algumas perguntas referentes a antecedentes patológicos, de modo a definir se o cliente está apto a realizar atividades físicas ou não.

\footnotetext{
${ }^{16} \mathrm{Na}$ maioria das vendas, são fechados pacotes trimestrais, nos quais o cliente ganha um desconto de $12 \%$.
} 
Existe um procedimento de diagnóstico presente nas primeiras avaliações física e fisioterápica, onde se define o tipo de treinamento a que o cliente deverá se submeter.

\subsubsection{Segunda fase - Atividades de monitoramento}

A academia tem um sistema informatizado para monitoramento das atividades. Para entrar e sair da academia, o aluno deve passar por uma roleta que solicita a leitura do seu número de inscrição gravado na carteirinha, portanto, a freqüência e o tempo de permanência de cada aluno são registrados. As principais medidas tomadas nas avaliações físicas e fisioterápicas são registradas em um sistema informatizado. Soma-se a isso a utilização de câmeras em todas as salas da academia, cujas imagens permanecem registradas por dois meses ${ }^{17}$.

Utilizando-se a estrutura conceitual de Grönroos (2003) e Holmlund (1997; 2004), discutida no referencial teórico, nota-se que o sistema de monitoramento implementado abrange três episódios. O primeiro episódio consiste na matrícula. $\mathrm{O}$ segundo consiste nas atividades de avaliação física e fisioterápica, onde o sistema contempla o registro de diferentes resultados dos vários exames realizados. O terceiro episódio consiste nas atividades de musculação propriamente ditas e o sistema de monitoramento implementado contempla o registro da entrada e saída dos alunos. O sistema implementado para o registro do relacionamento com os clientes pode ser esquematizado adotando-se a representação gráfica do Mapa de Relacionamento proposto na seção 3.3.4 conforme ilustra a Figura 5.1.

\footnotetext{
${ }^{17}$ As câmeras originalmente foram instaladas com o intuito de inibir o roubo de pertences dos clientes por outros clientes.
} 


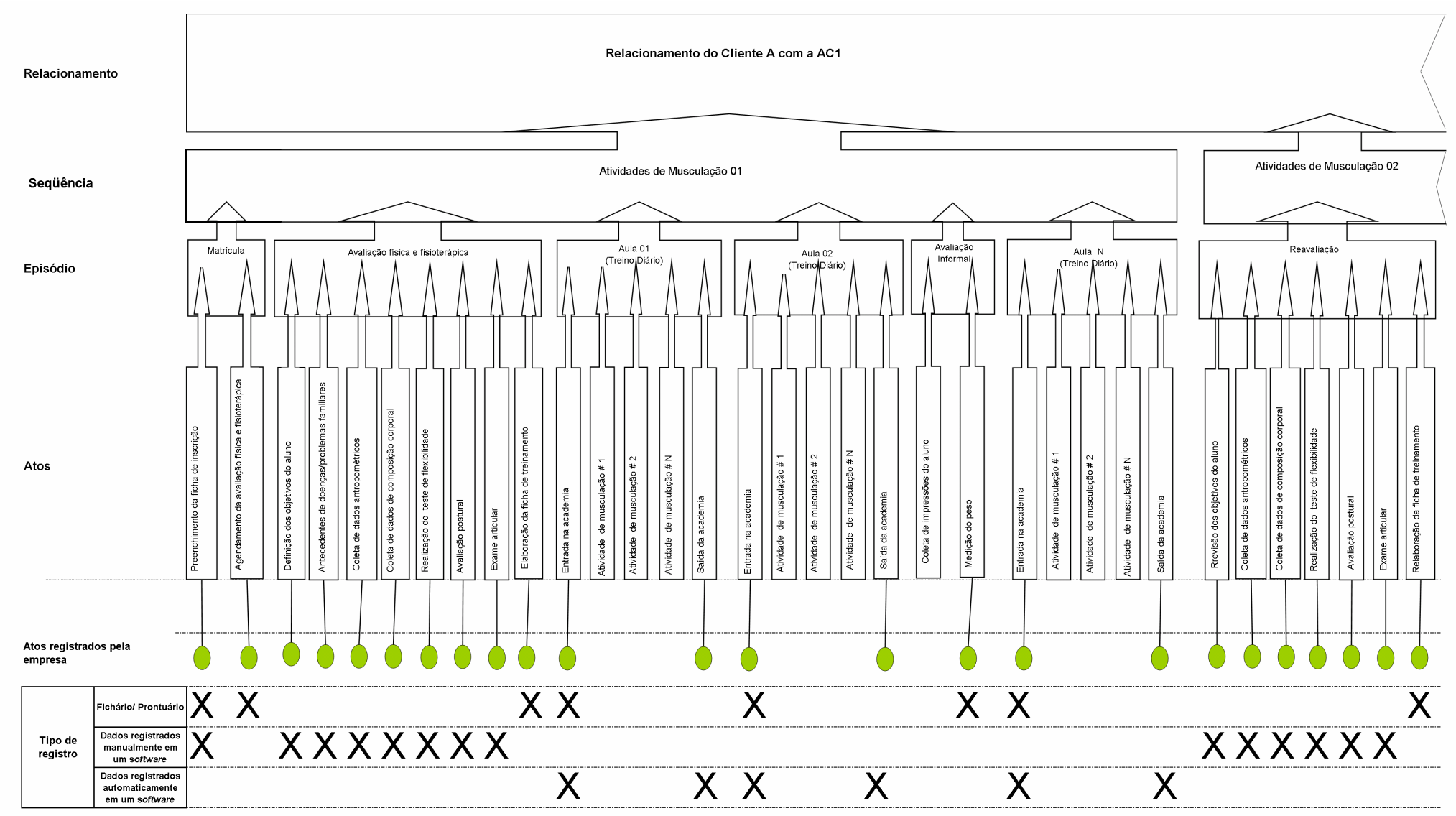

Três meses

FIGURA 5.1 - Mapa de relacionamento para o caso AC1

Fonte: Elaborada pelo Autor, 2007. 
Uma análise do Mapa de Relacionamento exposto na Figura 5.1 revela as principais características das práticas de acompanhamento das atividades realizadas pelo cliente na empresa $A C 1$. Verifica-se que alguns atos são registrados pelo sistema e que a maior parte da informação coletada refere-se a informações pontuais, tais como data e horário de entrada na academia, valores antropométricos, etc.

De uma maneira mais detalhada, entende-se que as interações que constituem o relacionamento da academia com o cliente a ser monitorado, podem ser estruturadas como descreve o Quadro 5.2.

\begin{tabular}{|c|c|c|c|}
\hline Nível & \multicolumn{3}{|c|}{ Atividades } \\
\hline Seqüência & \multicolumn{3}{|l|}{ Atividades de musculação } \\
\hline Episódio & $\begin{array}{l}\text { Avaliações física e fisioterápica com } \\
\text { duração média de } 40-60 \text { minutos }\end{array}$ & $\begin{array}{l}\text { Avaliações informais realizadas } \\
\text { com a periodicidade de } 10 \text { dias }\end{array}$ & $\begin{array}{l}\text { Treinamento diário por um } \\
\text { período de três meses ou mais. } \\
\text { Cada aula dura em torno de } 60 \text { - } \\
90 \text { minutos }\end{array}$ \\
\hline \multirow[t]{8}{*}{ Principais Atos } & $\begin{array}{l}\text { Definição/revisão dos objetivos do } \\
\text { aluno }\end{array}$ & Medição do peso & Entrada na academia \\
\hline & $\begin{array}{l}\text { Registro dos antecedentes de } \\
\text { doenças/problemas familiares }\end{array}$ & \multirow[t]{7}{*}{$\begin{array}{l}\text { Coletas de impressões do aluno } \\
\text { sobre a ginástica como um todo }\end{array}$} & $\begin{array}{l}\text { Realização de atividades de } \\
\text { musculação previstas na ficha } \\
\text { de treinamento }\end{array}$ \\
\hline & Coleta de dados antropométricos & & \multirow[t]{6}{*}{ Saída da academia } \\
\hline & $\begin{array}{l}\text { Coleta de dados de composição } \\
\text { corporal }\end{array}$ & & \\
\hline & Realização do teste de flexibilidade & & \\
\hline & Avaliação postural & & \\
\hline & Exame articular & & \\
\hline & $\begin{array}{l}\text { Estabelecimento da ficha de } \\
\text { treinamento e recomendações } \\
\text { gerais ao aluno }\end{array}$ & & \\
\hline
\end{tabular}

QUADRO 5.2 - Atividades registradas no sistema de monitoramento no caso AC1

Fonte: Elaborado pelo autor, 2007.

\subsubsection{Segunda fase - Análise dos dados e tomada de ações}

A eficácia dos serviços é verificada nas reavaliações, nas quais se comparam os resultados obtidos com os resultados esperados. Essa reavaliação é opcional e deve ser feita em bases trimestrais, mas nem todos os clientes a realizam. Quando questionado como tais freqüentadores continuam realizando as atividades físicas, o sócio-diretor respondeu: 
[...] Ele (o cliente) começa a treinar, treinar, treinar... Vê que está emagrecendo. Perdeu cinco quilos, mas não teve a curiosidade de saber o que está perdendo, se é massa magra ou gordura. Ele poderia estar perdendo mais. (Fala do sócio-diretor)

Portanto, os clientes conseguem enxergar os resultados dos exercícios num certo nível, mas não conseguem compreender o porquê da magnitude dos resultados observados, nem conseguem definir o que deve ser melhorado ou modificado.

A freqüência e o tempo de permanência do cliente na academia são registrados. A ficha de treinamento registra também a freqüência do aluno. Esses dados podem ser consultados na reavaliação, quando o avaliador, juntamente com seu cliente, procuram compreender os motivos de um eventual não-atingimento dos objetivos estabelecidos.

Um grande problema constatado na pesquisa, e também reportado em textos específicos sobre as academias de ginástica, é a baixa taxa de retenção de seus clientes. Muitos iniciam as atividades, mas desistem de continuar ${ }^{18}$.

São realizadas também avaliações informais, quando o cliente mede seu peso (normalmente isso é feito a cada dez dias), e o instrutor questiona se ele está notando os efeitos da ginástica.

\subsubsection{Táticas que estimulam o envolvimento e a participação dos clientes}

1) Educação e treinamento para a realização das atividades.

- O caso AC1 realiza essa prática por meio dos monitores, que acompanham a realização dos exercícios pelos alunos

2) Realização de atividades que promovem a socialização dos clientes.

- O caso AC1 promove caminhadas, festas e gincanas. Dentro da academia, normalmente no sábado, são promovidos "aulões", em que se

\footnotetext{
${ }^{18}$ O sócio-diretor entrevistado reportou que apenas $20 \%$ a $25 \%$ dos clientes permanecem de um a dois anos na academia.
} 
juntam vários professores que ministram uma aula de step, de bicicleta, etc.

3) Compensações e/ou prêmios por maior envolvimento e participação do cliente nas atividades.

- O caso AC1 não adota esta prática. Oferece apenas planos trimestrais e semestrais com desconto para o pagamento adiantado das mensalidades.

4) Estabelecimento de regras de condutas e/ou comportamento

- O caso AC1 estabelece regras de comportamento referentes ao uso de roupas adequadas, que são entregues ao aluno durante a primeira avaliação. Existem regras referentes ao uso dos aparelhos e condutas que não estão formalizadas.

5) Oferecimento de algum tipo de suporte para a realização das atividades.

- Esta atividade faz parte das atividades de educação e treinamento realizadas pelos monitores.

6) Envolvimento do cliente no planejamento/definição das atividades.

- Durante a reavaliação, pergunta-se ao aluno com qual aparelho ele está tendo dificuldade. Diante do inconveniente reportado, o avaliador pode alterar a ficha de treinamento.

7) Conscientização da importância do adequado cumprimento das atividades sob a responsabilidade do cliente.

- São feitos alguns chamados, colocados no quadro de aviso, expondo a importância de aspectos importantes para a musculação. São exemplos desses aspectos: importância do alongamento, importância de estar bem alimentado, importância da reavaliação, etc. 


\subsection{CASO 2: GRANDE ACADEMIA DE GINÁSTICA - ATIVIDADES DE MUSCULAÇÃO (AC2)}

\subsubsection{Caracterização da empresa}

O segundo caso de academia de ginástica considerada (AC2) faz parte dos serviços oferecidos por um grande clube esportivo. Trata-se de uma academia de grande porte que existe neste clube há cerca de 30 anos e atualmente possui duas unidades que atendem a cerca de 1.200 alunos cada uma. $O$ serviço oferecido consiste basicamente da atividade de musculação ${ }^{19}$. Apenas os sócios do clube, a partir de 15 anos, podem procurar esse serviço. Funciona por turnos (manhã, tarde e noite). Os alunos de um turno não podem freqüentar o outro ${ }^{20}$.

\subsubsection{Coleta de dados}

Os dados foram coletados por intermédio de entrevistas com a supervisora da academia. Foram consultados também relatórios e alguns registros utilizados pela empresa.

\subsubsection{Processo de entrega do serviço}

Consiste de várias atividades que vão desde a solicitação de reserva na Central de Atendimento à solicitação de cancelamento das atividades. O fluxograma

\footnotetext{
${ }^{19}$ O serviço de musculação consiste basicamente no treinamento físico em máquinas.

${ }^{20}$ Essa medida foi tomada no sentido de diminuir a fila de espera para a musculação. Antes desse sistema, a fila de espera para inscrição chegava a ter 1.500 pessoas e, atualmente, existem cerca de 500 .
} 
da Figura 5.2 ilustra a seqüência das principais atividades realizadas para a entrega do serviço.

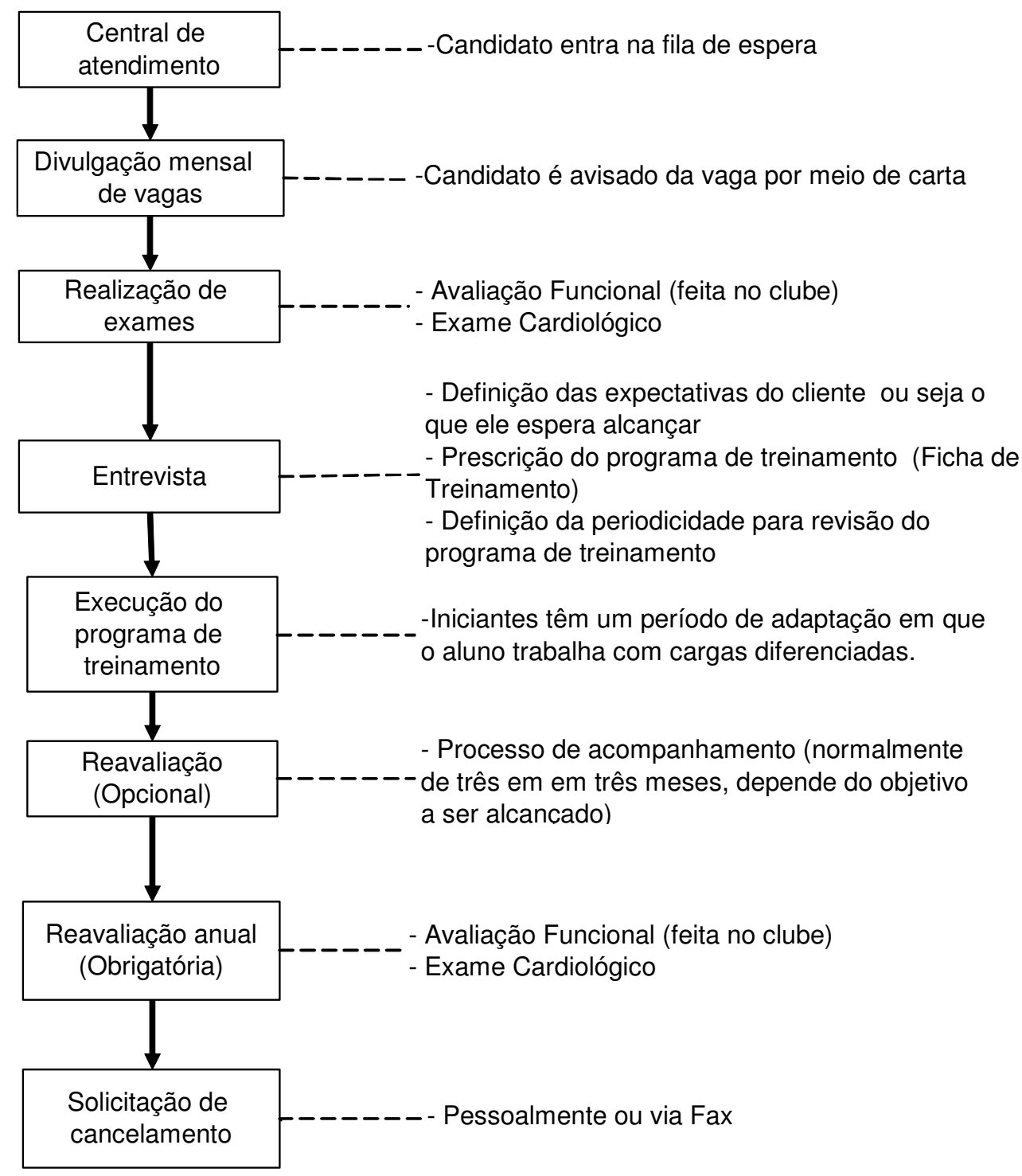

FIGURA 5.2 - Principais atividades realizadas no caso AC2

Fonte: Pesquisa do autor, 2007. 


\subsubsection{Sistema de monitoramento e controle dos clientes}

\subsubsection{Primeira fase - Procedimentos de seleção e de diagnóstico}

Existe um procedimento de seleção dos clientes, dois exames solicitados cardiológico e funcional - definem se o cliente está apto a realizar atividades físicas ou não.

Existe um procedimento de seleção dos clientes. Após comprovação da aptidão do aluno para a realização de atividades físicas, uma vez matriculado, o cliente passa por uma entrevista com o professor para o estabelecimento de metas a serem alcançadas e prescrição da rotina de exercícios ideais para o cumprimento das mesmas.

\subsubsection{Segunda fase - Atividades de monitoramento}

O caso AC2 tem um sistema informatizado para monitoramento dos seus sócios no clube, e isso inclui as atividades de musculação. Vários atos são registrados pelos diferentes sistemas de gestão. Existe um sistema de gestão para o clube e um software específico para monitoramento dos exames funcionais e do programa de treinamento.

Para entrar na academia, é preciso passar por uma roleta que solicita a leitura do número de inscrição que consta na carteirinha, ou mostrar a digital para o leitor existente. Apenas a entrada do aluno é registrada.

Utilizando-se a estrutura conceitual de Grönroos (2003) e Holmlund (1997; 2004), discutida no referencial teórico, pode-se visualizar que o sistema de monitoramento implementado deve acompanhar o relacionamento com os alunos por várias seqüências. Isso ocorre na medida em que diferentes seqüências que ocorrem ao longo do relacionamento do cliente com o clube são monitoradas, não 
apenas as atividades referentes à musculação. Os principais episódios que constituem estas seqüências bem como os atos registrados pelo sistema de monitoramento referentes à musculação são mostrados no Mapa de Relacionamento exposto na Figura 5.3. 


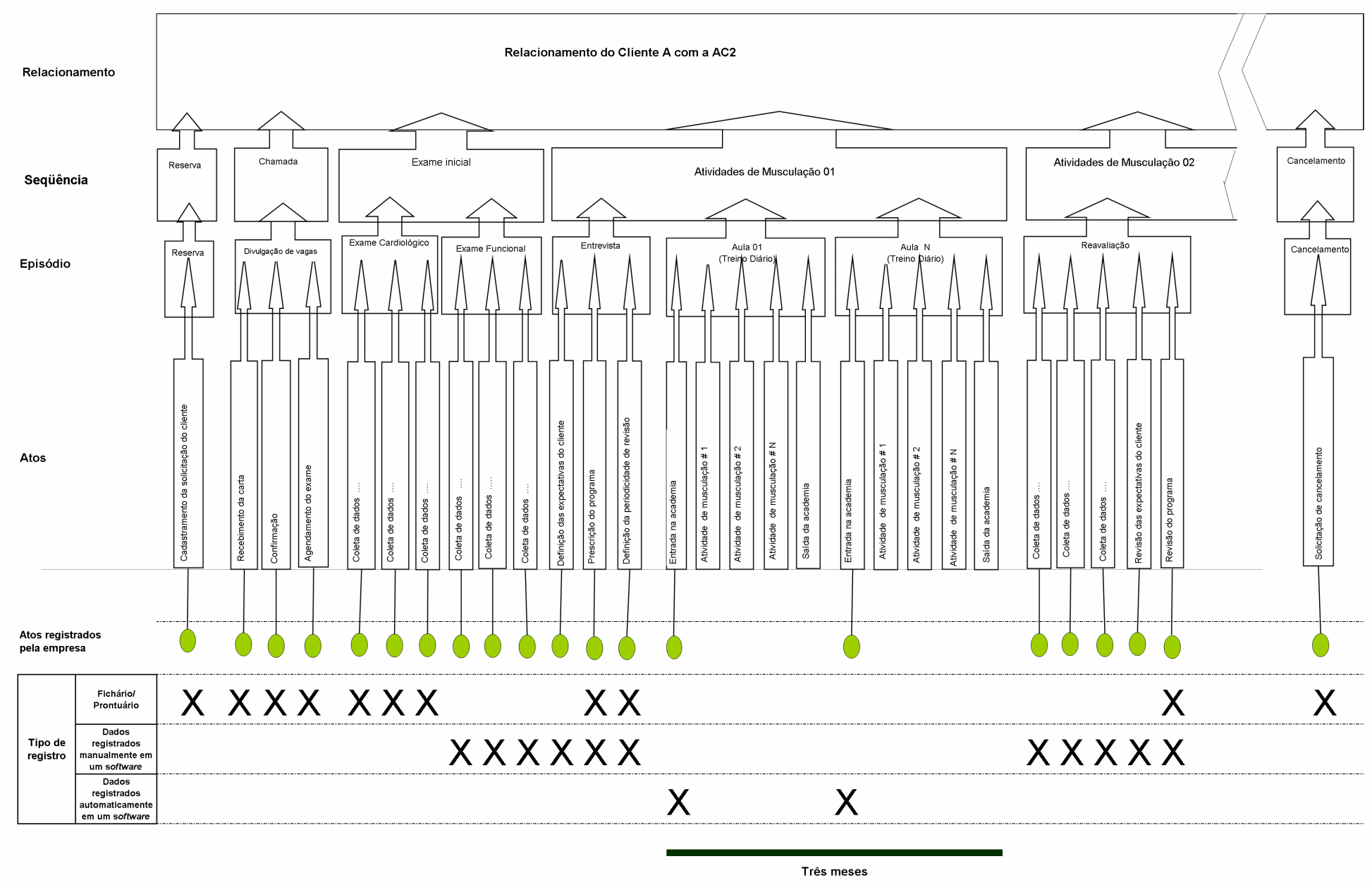

FIGURA 5.3 - Mapa de relacionamento para a grande academia

Fonte: Pesquisa do autor, 2007. 
Uma análise do Mapa de Relacionamento exposto na Figura 5.3 revela as principais características das práticas de acompanhamento das atividades realizadas pelo cliente no caso AC2. Alguns atos são registrados pelo sistema, mas a maior parte da informação coletada refere-se a informações pontuais, tais como data e horário de entrada na academia, valores do percentual de gordura, medida de circunferência, etc.

A estrutura de relacionamento desta grande academia pode ser descrita, de uma maneira mais detalhada, como indica o Quadro 5.3.

\begin{tabular}{|c|c|c|c|c|c|c|c|}
\hline Nível & \multicolumn{7}{|c|}{ Atividade } \\
\hline Seqüência & Reserva & Chamada & \multicolumn{2}{|c|}{$\begin{array}{l}\begin{array}{l}\text { Exame inicial ou anual } \\
\text { (obrigatórios) }\end{array} \\
\end{array}$} & \multicolumn{3}{|c|}{ Atividades de musculação } \\
\hline Episódio & $\begin{array}{l}\text { Central de } \\
\text { atendimento } \\
\text { registra } \\
\text { solicitação de } \\
\text { reserva do } \\
\text { cliente }\end{array}$ & $\begin{array}{l}\text { Carta enviada } \\
\text { ao cliente } \\
\text { solicitando o } \\
\text { compareci- } \\
\text { mento e a } \\
\text { realização } \\
\text { dos exames }\end{array}$ & $\begin{array}{l}\text { Exame } \\
\text { Cardiológico } \\
\text { (Até } 40 \text { anos: } \\
\text { apenas } \\
\text { atestado } \\
\text { cardiológico } \\
\text { simples e } \\
\text { acima de } 40 \\
\text { anos: teste } \\
\text { ergométrico) } \\
\end{array}$ & \begin{tabular}{|l} 
Exame \\
Funcional
\end{tabular} & \begin{tabular}{|l|} 
Entrevista/ \\
reavaliação
\end{tabular} & $\begin{array}{l}\text { Exame } \\
\text { Funcional }\end{array}$ & \begin{tabular}{|l} 
Treinamento \\
diário. \\
Duração \\
prevista de \\
três meses ol \\
mais. Cada \\
aula dura em \\
torno de $60-$ \\
90 minutos \\
\end{tabular} \\
\hline $\begin{array}{l}\text { Principais } \\
\text { atos }\end{array}$ & $\begin{array}{l}\text { Coleta de } \\
\text { dados } \\
\text { referentes à } \\
\text { solicitação de } \\
\text { reserva pelo } \\
\text { cliente }\end{array}$ & $\begin{array}{l}\text { Recebimento } \\
\text { da carta } \\
\text { Confirmação } \\
\text { Agendamento } \\
\text { do exame }\end{array}$ & \begin{tabular}{|l|} 
Coleta de \\
vários dados \\
neste exame
\end{tabular} & $\begin{array}{l}\text { Coleta de } \\
\text { vários dados } \\
\text { neste exame: } \\
\text { percentual de } \\
\text { gordura, } \\
\text { circunferência } \\
\text { etc. }\end{array}$ & \begin{tabular}{|l} 
Definição/ \\
revisão dos \\
objetivos do \\
aluno \\
Elaboração/ \\
revisão do \\
programa de \\
treinamento
\end{tabular} & $\begin{array}{l}\text { Coleta de } \\
\text { vários dados } \\
\text { neste exame: } \\
\text { percentual de } \\
\text { gordura, } \\
\text { circunferência } \\
\text {, etc. }\end{array}$ & $\begin{array}{l}\text { Entrada na } \\
\text { academia } \\
\text { Atividades de } \\
\text { musculação } \\
\text { previstas na } \\
\text { ficha de } \\
\text { treinamento } \\
\text { Saída da } \\
\text { academia }\end{array}$ \\
\hline
\end{tabular}

QUADRO 5.3 - Atividades registradas no sistema de monitoramento no caso AC2

Fonte: Pesquisa do autor, 2007.

\subsubsection{Segunda fase - Análise dos dados e tomada de ações}

A eficácia dos serviços é verificada nas reavaliações (opcionais), nas quais se comparam os resultados obtidos com aqueles esperados. Sua periodicidade é variável, dependendo dos objetivos do cliente, mas, de uma maneira geral, é trimestral. O clube obriga seus alunos a realizarem, no mínimo, uma avaliação anual, que abrange os exames funcional e cardiológico. Na entrada da academia, a roleta 
impede acesso se a data para a realização do exame anual tiver expirado. Neste momento, o cliente deve agendar esses exames num prazo máximo de 30 dias.

Os atendentes têm como tarefa, periodicamente, verificar as datas de renovação dos programas de treinamento. As fichas em período de renovação são retiradas do fichário normal e transferidas para outro. Isso faz com que os alunos nessa situação procurem os atendentes. Estes, então, agendam os exames para a renovação do programa de treinamento. Apesar de os exames serem pagos, devido ao poder aquisitivo dos sócios, a grande maioria realiza a reavaliação.

A freqüência do cliente no caso AC2 é registrada. Estes dados podem ser consultados, na reavaliação, quando o avaliador juntamente com o cliente procuram compreender os motivos de eventual não-atingimento dos objetivos estabelecidos. Caso necessário, fatores externos sob o controle do cliente, como freqüência e dieta, são discutidos nesta reavaliação.

\subsubsection{Táticas que estimulam o envolvimento e a participação dos clientes}

1) Educação e treinamento do cliente para a realização das atividades.

- O caso AC2 realiza esta prática por intermédio dos instrutores/estagiários que acompanham o aprendizado dos exercícios pelos alunos

2) Realização de atividades que promovem a socialização dos clientes.

- O caso AC2 promove caminhadas, festas e pequenos eventos, como campeonato de flexão de braços, "circuitão", etc.

3) Compensações e/ou prêmios por maior envolvimento e participação do cliente nas atividades.

- O caso AC2 não adota esta prática.

4) Estabelecimento de regras de condutas e/ou comportamento.

- O caso AC2 estabelece regras de comportamento divulgadas por um banner.

- Existem também regras para uso de alguns dos equipamentos. 
- O clube contém uma comissão de disciplina que lida com eventuais excessos de comportamentos dos clientes.

5) Oferecimento de algum tipo de suporte para a realização das atividades.

- Existem cartazes e banners explicativos. Fazem parte das atividades de educação e treinamento realizadas pelos professores e estagiários.

6) Envolvimento do cliente no planejamento/definição das atividades.

- Durante o planejamento do treinamento o aluno é consultado sobre suas preferências. Essa informação é levada em consideração pelo avaliador, que pode alterar a ficha do programa de treinamento.

7) Conscientização da importância do adequado cumprimento das atividades sob a responsabilidade do cliente.

- São feitas, de modo informal, pelo professor ou monitor, através de correção durante as aulas.

\subsection{CASO 3: CURSOS DE APERFEIÇOAMENTO PROFISSIONAL PARA RECOLOCAÇÃO E REINSERÇÃO SOCIAL (SS1)}

\subsubsection{Caracterização da entidade ${ }^{21}$}

A entidade pesquisada (SS1) tem como objetivo oferecer aos jovens pertencentes aos segmentos menos favorecidos da população residente na região Norte da capital mineira, a possibilidade de formação para o mercado de trabalho oferecendo um serviço de aperfeiçoamento profissional visando à recolocação e reinserção social. Além disso, visa criar oportunidades para geração e complementação de renda.

Atualmente o caso SS1 oferece cursos para os seguintes cargos ou habilidades:

\footnotetext{
${ }^{21}$ O termo "empresa" foi substituído por "entidade", pois essa terminologia é a utilizada por organizações deste setor.
} 
- auxiliar administrativo: oferecido em parceria com a Fundação Clube de Diretores Lojistas (CDL). O seu público consiste de jovens de 14 anos e nove meses a jovens de 15 anos e nove meses. A grande maioria é encaminhada ao Banco do Brasil, onde trabalham até seus 18 anos de idade;

- office boy e office girl;

- recepcionista;

- telemarketing;

- informática básica;

- técnicas de vendas.

Além destes cursos, esta entidade contempla dois outros projetos:

- Projeto BICA (Buscando Integração pela Arte): oferecido para crianças de 6 a 14 anos. Desenvolvem-se atividades como jogos, dança, teatro, passeios e também algumas atividades de orientação junto às famílias das crianças;

- Projeto ARTE NÓS: objetiva buscar uma renda alternativa para as famílias atendidas. Isso ocorre mediante capacitação das mulheres pertencentes a essas famílias, em oficinas de arranjo de flores, pintura de tecidos, costura, etc.

\subsubsection{Coleta de dados}

Dentre os serviços oferecidos pela entidade, o trabalho analisará aqueles que objetivam a inserção dos jovens no mercado de trabalho. O estudo de caso foi conduzido por meio de entrevistas semi-estruturadas com a coordenadora dos cursos oferecidos. Foram também consultados relatórios internos, formulários utilizados no ato da inscrição, questionário de avaliação do curso e o diário de classe de algumas turmas. 


\subsubsection{Processo de entrega do serviço}

De um modo geral, duas categorias de seqüências de atividades formam os serviços de formação educacional. A primeira categoria consiste na realização do curso propriamente dito. Ela é formada por três tipos de episódios. O primeiro tipo de episódio refere-se à inscrição e à seleção dos alunos. O segundo consiste na realização do curso de aperfeiçoamento profissional em si. Exige-se uma freqüência mínima de $90 \%$. O terceiro tipo de episódio consiste na avaliação do curso pelos alunos, a qual abrange:

- avaliação do próprio curso: itens como duração, material utilizado, adequação do local, horário das aulas e quantidade de alunos por sala são avaliados por cada aluno;

- avaliação do instrutor: avalia aspectos como domínio de conteúdo, capacidade de acompanhamento das dificuldades do aluno e seu relacionamento com a turma;

- avaliação geral da entidade em termos de atendimento;

- auto-avaliação do aluno, quanto ao seu aproveitamento, sua colaboração, sua freqüência e seu nível de entrosamento com a turma.

A segunda categoria de seqüência refere-se à seleção e ao encaminhamento do aluno à oferta de emprego, bem como ao acompanhamento do resultado deste esforço de recolocação e reinserção social. 


\subsubsection{Sistema de monitoramento e controle dos clientes}

\subsubsection{Primeira fase - Procedimentos de seleção e de diagnóstico}

O caso SS1 apresenta uma rotina formalizada de seleção. Refere-se à primeira seqüência do sistema de relacionamento entre a entidade e o cliente $^{22}$, e consiste no episódio de seleção dos alunos que se desdobra em vários atos: i) conferência dos documentos, em que a ausência de qualquer comprovante desclassifica o candidato; ii) análise da ficha socioeconômica, privilegiando-se os candidatos mais carentes; iii) verificação da adequação do perfil do candidato à proposta do curso e aos requisitos solicitados pelas empresas conveniadas. Normalmente, as exigências são especificadas em termos do grau de escolaridade, idade e habilidades. Segundo a coordenadora, normalmente, cerca de $20 \%$ dos inscritos são selecionados

Não há uma rotina de diagnóstico estabelecida pela entidade.

\subsubsection{Segunda fase - Atividades de monitoramento}

As duas categorias de seqüências de atividades relatadas anteriormente são registradas. Para cada uma delas existem formulários específicos.

Além do cadastro de cada aluno, é feito também um monitoramento do cliente durante os cursos. A coordenadora do projeto destacou a importância da freqüência e da participação. Nesses cursos, apenas um determinado percentual de faltas é tolerado, e o empenho dos alunos é monitorado, mesmo que de forma manual. Utilizando-se a estrutura conceitual de Grönroos (2003) e Holmlund (1997; 2004), discutida no referencial teórico, pode-se visualizar o curso de aperfeiçoamento oferecido pelo caso caso SS1 é um SRU desenvolvido ao longo de seqüências de

\footnotetext{
${ }^{22}$ Neste setor o nome "cliente" normalmente é substituído por "assistido".
} 
episódios que, por sua vez, se desdobram em atos. O sistema de monitoramento implementado para o acompanhamento do relacionamento com os clientes inclui o registro de vários atos como esquematizado no Mapa de Relacionamento apresentado pela Figura 5.4. 


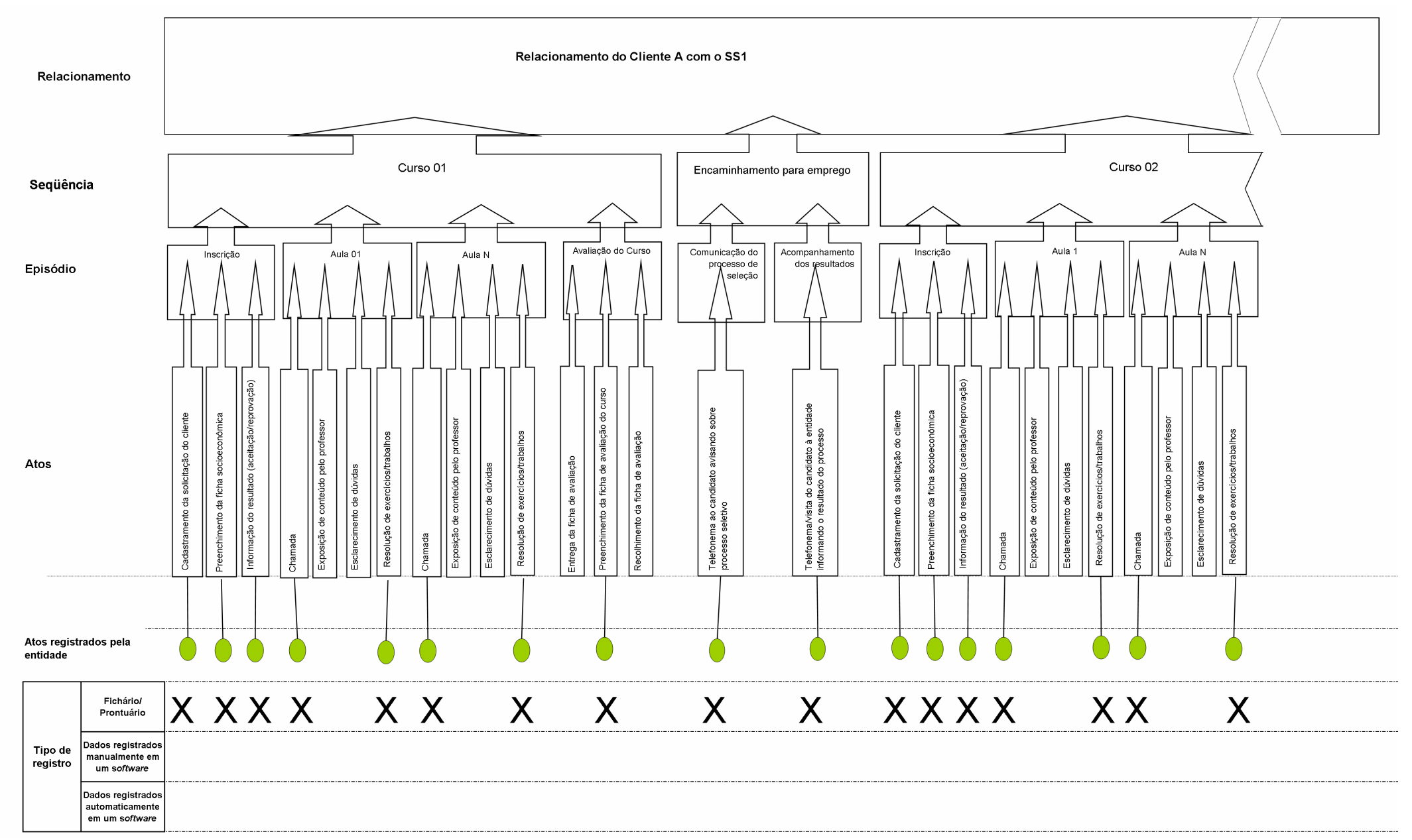

FIGURA 5.4 - Mapa de relacionamento para os cursos de aperfeiçoamento profissional

Fonte: Pesquisa do autor, 2007. 
Uma análise do Mapa de Relacionamento exposto na Figura 5.4 revela as principais características das práticas de acompanhamento das atividades realizadas pelo cliente no caso SS1. Alguns atos são registrados pelo sistema através de formulários ou fichários, não existindo um software para manipular estes dados. $A$ maior parte da informação coletada refere-se a informações pontuais, tais como freqüência do aluno, nota final obtida, etc.

No Quadro 5.4 pode ser visualizada, de uma maneira mais detalhada, a maneira como o relacionamento foi estruturado no ano de 2005. Este quadro indica ainda números que caracterizam o volume de atendimentos de pessoas no caso SS1.

\begin{tabular}{|c|c|c|}
\hline Nível & \multicolumn{2}{|l|}{ Atividades } \\
\hline Seqüência & $\begin{array}{l}\text { Cursos } \\
\text { - Excelência em telemarketing e atendimento/40 horas (123 } \\
\text { certificadas em } 150 \text { inscritas) } \\
\text { - Recepcionista/40 horas ( } 45 \text { certificadas em } 60 \text { inscritas) } \\
\text { - Office-Boy/Girl/ } 40 \text { horas ( } 20 \text { certificadas em } 30 \text { inscritas) } \\
\text { - Inclusão Digital/ } 40 \text { horas ( } 231 \text { certificadas em } 320 \text { inscritas) } \\
\text { - Técnicas de Vendas/ } 40 \text { horas ( } 23 \text { certificadas em } 30 \text { inscritas) } \\
\text { - Auxiliar Administrativo/ } 60 \text { horas ( } 26 \text { certificadas em } 30 \text { inscritas) }\end{array}$ & $\begin{array}{l}\text { Encaminhamento para emprego } \\
\text { (365 pessoas foram encaminhadas no ano de } \\
2005 \text { e } 169 \text { foram empregadas) }\end{array}$ \\
\hline \multirow[t]{3}{*}{ Episódio } & $\begin{array}{l}\text { Inscrição/Seleção } \\
\text { (Realizadas às terças e quintas-feiras em data específica para } \\
\text { cada curso) }\end{array}$ & $\begin{array}{l}\text { Comunicação de oportunidade de } \\
\text { processo de seleção aos candidatos }\end{array}$ \\
\hline & Aulas & \multirow[t]{2}{*}{ Acompanhamento dos resultados } \\
\hline & $\begin{array}{l}\text { Avaliação do curso pelo aluno } \\
\text { (Uma avaliação realizada pelo aluno ao final de cada curso) }\end{array}$ & \\
\hline \multirow[t]{3}{*}{ Principais atos } & $\begin{array}{cl}\text { Na Inscrição/Seleção: } \\
-\quad \text { Conferência dos documentos } \\
-\quad \text { Preenchimento da ficha socioeconômica } \\
\text { - } \quad \text { Informação do resultado (aceitação/reprovação) }\end{array}$ & $\begin{array}{l}\text { Na comunicação de oportunidade de } \\
\text { processo de seleção aos candidatos } \\
\text { - Telefonema ao candidato avisando } \\
\text { sobre processo seletivo }\end{array}$ \\
\hline & $\begin{array}{cl}\text { Nas aulas } & \\
- & \text { Chamada } \\
- & \text { Vários atos que formam a aula propriamente dita }\end{array}$ & \multirow[t]{2}{*}{$\begin{array}{l}\text { No acompanhamento dos resultados } \\
\text { - Telefonema/visita do candidato à } \\
\text { entidade informando o resultado do } \\
\text { processo }\end{array}$} \\
\hline & $\begin{array}{cl}\text { Na avaliação do curso pelo aluno } \\
\text { - } & \text { Entrega da ficha de avaliação } \\
\text { - } & \text { Preenchimento da ficha de avaliação do curso } \\
\text { - } & \text { Recolhimento da ficha de avaliação }\end{array}$ & \\
\hline
\end{tabular}

QUADRO 5.4 - Atividades registradas, sua duração, quantidade de pessoas inscritas e certificadas

Fonte: Pesquisa do autor, 2007. 


\subsubsection{Segunda fase - Análise dos dados e tomada de ações}

A eficácia dos serviços é verificada pelo acompanhamento dos processos seletivos. A grande maioria das oportunidades de emprego é divulgada por uma entidade ${ }^{23}$ que, posteriormente, fornece o resultado desses processos.

A cada ano, o caso SS1 reavalia cada projeto e determina metas, principalmente, em relação à quantidade de pessoas que deverão ser atendidas por cada curso. Esses valores são acompanhados mensalmente pela administração.

Como existe uma certa taxa de desistência nos cursos, a coordenadora, normalmente, abre uma quantidade maior de vagas para que as metas de número de pessoas a serem atendidas sejam atingidas.

A definição dos cursos e do conteúdo que serão oferecidos é feita de modo a considerar os conhecimentos e habilidades exigidos pelo mercado. Essa tarefa é realizada mediante análise do perfil das vagas de emprego que estão sendo oferecidas e pelo contato da coordenadora com as empresas solicitantes.

\subsubsection{Táticas que estimulam o envolvimento e a participação dos clientes}

1) Educação e treinamento do cliente para a realização das atividades.

- As atividades se referem à formação e educação em si.

2) Realização de atividades que promovem a socialização dos clientes.

- São feitos trabalhos em equipe.

3) Compensações e/ou prêmios por maior envolvimento e participação do cliente nas atividades.

- O caso SS1 não adota esta prática.

4) Estabelecimento de regras de condutas e/ou comportamento.

\footnotetext{
${ }^{23}$ Esta entidade é a Rede Cidadã, uma Organização Não Governamental (ONG) que faz a prospecção de ofertas de emprego junto ao mercado e repassa essas ofertas às empresas conveniadas.
} 
- O caso SS1 estabelece regras de comportamento e exige um percentual mínimo de freqüência para aprovação.

5) Oferecimento de algum tipo de suporte para a realização das atividades.

- O caso SS1 não realiza esta prática.

6) Envolvimento do cliente no planejamento/definição das atividades.

- A avaliação de cada curso pelo aluno é considerada pela entidade para planejar a próxima turma daquele curso.

7) Conscientização da importância do adequado cumprimento das atividades sob a responsabilidade do cliente.

- Na inscrição, o objetivo do curso é apresentado ao aluno pelo funcionário da secretaria, e as regras são apresentadas pelo professor em sala no primeiro dia de aula.

\subsection{CASO 4: CURSOS DE APERFEIÇOAMENTO PROFISSIONAL PARA INSERÇÃO SOCIAL NO MUNDO DO TRABALHO (SS2)}

\subsubsection{Caracterização da entidade}

A caracterização da entidade estudada neste caso (SS2) parte do esclarecimento de sua política de inclusão social de pessoas com necessidades especiais. Trata-se de um dado indispensável, na medida em que sua missão é incluir a pessoa com deficiência na escola, no trabalho e na sociedade. O caso SS2 acredita que a inclusão do jovem deficiente no mundo do trabalho não pode se dar dentro da lógica convencional, que se preocupa com adaptação do deficiente ao mundo externo. Esta adaptação se dá pela alienação, formando uma mão-de-obra dócil e pronta para atividades repetitivas e sem sentido. Tal prática, na verdade, apenas agrava tanto o quadro social de exclusão como o quadro subjetivo da alienação (BATISTA, 2000). O caso SS2 acredita na inclusão ao trabalho via 
empoderamento $^{24}$ e capacitação do jovem. Segundo Sassaki (2000), a partir da comparação desta nova visão com aquela do passado, várias diferenças podem ser notadas e o Quadro 5.5 as contrapõe.

\begin{tabular}{|l|l|}
\hline \multicolumn{1}{|c|}{ Visão do passado } & \multicolumn{1}{c|}{ Nova visão } \\
\hline A família e a instituição decidem pela pessoa. & $\begin{array}{l}\text { A família e a instituição decidem com a pessoa e/ou a } \\
\text { própria pessoa decide. }\end{array}$ \\
\hline $\begin{array}{l}\text { A família e a instituição ensinam a pessoa a não } \\
\text { discordar daqueles que a ajudam. }\end{array}$ & $\begin{array}{l}\text { A família e a instituição ensinam a pessoa a ser } \\
\text { assertiva, mesmo quando discorda dos que a ajudam. }\end{array}$ \\
\hline $\begin{array}{l}\text { A instituição prepara a pessoa para o despreparo do } \\
\text { mercado de trabalho. }\end{array}$ & $\begin{array}{l}\text { A instituição prepara a pessoa e prepara o mercado de } \\
\text { trabalho simultaneamente. }\end{array}$ \\
\hline $\begin{array}{l}\text { O treinamento e/ou habilitação são feitos na instituição } \\
\text { de uma maneira alienada da realidade empresarial. }\end{array}$ & $\begin{array}{l}\text { O treinamento e/ou habilitação são feitos na instituição } \\
\text { de uma maneira sintonizada com a realidade } \\
\text { empresarial e/ou aos cursos existentes na } \\
\text { comunidade. }\end{array}$ \\
\hline
\end{tabular}

QUADRO 5.5 - Visões a respeito do jovem com necessidades especiais

Fonte: Baseado em Sassaki (2000)

\subsubsection{Coleta de dados}

Dentre os serviços oferecidos pelo caso $S S 2^{25}$, o presente trabalho analisou como caso o Núcleo de Educação Profissional - Nepro, um programa para adolescentes e jovens maiores, de 14 a 25 anos, com o objetivo de prepará-los para o mundo do trabalho. O Nepro tem capacidade de atender 350 jovens por ano, sendo que no ano de 2005, atendeu 244 jovens. A quantidade média de jovens em atendimento num mês é de cerca de 140.

Este programa é tido como referência nacional em atividades de inclusão social de jovens com necessidades especiais (deficiência mental).

Os dados foram coletados por meio de entrevistas com a supervisora do programa. Foram consultados também relatórios de atividades e alguns formulários utilizados pela entidade para registro das atividades de avaliação.

\footnotetext{
${ }^{24}$ Empoderamento ou Empowerment é o processo pelo qual uma pessoa utiliza o seu poder pessoal para fazer escolhas, decidir por si mesma e assumir o controle de sua vida (Sassaki, 2000).

${ }^{25}$ Além do Nepro, a entidade é constituída de mais quatro núcleos: Núcleo de Intervenção Precoce, Núcleo de Atendimento Pedagógico e Clínico Intensivo, Núcleo de Atendimento Pedagógico e Clínico Ambulatorial e Núcleo de Atendimento à Família.
} 


\subsubsection{Processo de entrega do serviço}

O processo é constituído de quatro fases distintas como seguem:

- Triagem - Os jovens são cadastrados pelo serviço social da entidade e entram numa fila de espera. Ao serem chamados, são submetidos a uma avaliação inicial por vários profissionais. Com base nesta avaliação, se aprovados, poderão ser avaliados pedagogicamente. Nessa avaliação, eles ficam em várias oficinas sendo avaliados durante 30 dias. Caso sejam selecionados, passam para a segunda fase.

- Fase pré-profissionalizante - Tem a duração de um ano. Nesta fase, o jovem passa pelo desenvolvimento de competências básicas nas oficinas e salas temáticas. A partir desta experiência, poderá fazer escolhas e identificar-se com um tipo de ofício. Nesse estágio, procura-se desenvolver habilidades básicas e oferecer oportunidades para o jovem exercitar a cidadania por meio de práticas que lhe permitirão ter sua primeira documentação e experimentar o exercício cívico.

- Fase de Qualificação e Habilitação para o Trabalho - Tem a duração de um ano. Realizada pela prestação de serviços a empresas. Esta fase, é o momento do treinamento que também inclui práticas consideradas repetitivas em programas de prestação de serviços. Porém, apesar de realizar tarefas repetitivas, como montagem de peças, a entidade procurar dar sentido a esta prática. Isso é feito por intermédio de ações como: i) seleção do que vai fazer; ii) participação em várias etapas do processo para conhecer o destino de seu trabalho bem como 0 o produto final do mesmo; iii) desenvolvimento de habilidades de gestão para a pessoa saber gerir o "seu fazer".

- Colocação no Mundo do Trabalho - Compreende os estágios e as colocações seletivas no mundo do trabalho sob supervisão de uma equipe. Esta acompanha todas as etapas de inclusão do jovem numa empresa (sua admissão, o acompanhamento das atividades realizadas e 
sua adaptação àquelas). Existe também um acompanhamento do jovem junto à sua família, por exemplo, educando seus familiares e o jovem para o controle financeiro dos provimentos que receber.

\subsubsection{Sistema de monitoramento e controle dos clientes}

\subsubsection{Primeira fase - Procedimentos de seleção e de diagnóstico}

$\mathrm{Na}$ fase inicial de triagem, uma extensa seqüência constituída de rotinas de avaliação é cumprida para a seleção dos jovens a serem admitidos pelo Nepro.

$\mathrm{Na}$ fase inicial de triagem, antes de um jovem candidato ser selecionado, ele é meticulosamente diagnosticado por uma equipe multifuncional da entidade SS2.

\subsubsection{Segunda fase - Atividades de monitoramento}

O jovem com necessidades especiais que realiza as atividades para capacitação profissional no Nepro pode também receber o apoio clínico ${ }^{26}$ que se julgar necessário para o seu desenvolvimento. No ano de 2005, o Nepro encaminhou 5 jovens para a fisioterapia, 6 para a fonoaudiologia, 5 para o médico pediatra, 7 para o médico psiquiatra, 42 para a psicologia e 13 para a terapia ocupacional.

Utilizando-se a estrutura conceitual de Grönroos (2003) e Holmlund (1997; 2004), pode-se perceber que o processo de serviço do caso SS2 se estende por uma longa série de episódios que constituem cinco seqüências principais e que, no dia a dia, os episódios se desdobram em freqüentes atos. O sistema de

\footnotetext{
${ }^{26}$ Existem várias modalidades de apoio clínico na entidade, tais como: Medicina (pediatria e psiquiatria), Psicologia, Terapia Ocupacional, Fonoaudiologia, Fisioterapia, Enfermagem, Serviço Social e Pedagogia.
} 
monitoramento implementado está organizado para acompanhar o desenvolvimento dos jovens ao longo das várias seqüências. Isso é crucial para a condução do processo de serviço, na medida em que o jovem não está vinculado apenas ao Nepro, mas à entidade como um todo, interagindo com seus diferentes núcleos de apoio. As atividades clínicas registram vários atos por meio dos prontuários das consultas e dos exames realizados. As atividades do Nepro não seguem uma rotina rígida e são permeadas por várias avaliações conduzidas com reuniões periódicas. Pode-se entender que no caso SS2 o sistema implementado de monitoramento registra 0 relacionamento com os clientes conforme indica o Mapa de Relacionamento exposto na Figura 5.5.

Vale notar que dependendo da evolução do jovem, sua colocação no mundo do trabalho pode ocorrer mais cedo, abreviando-se a fase de qualificação e habilitação. 


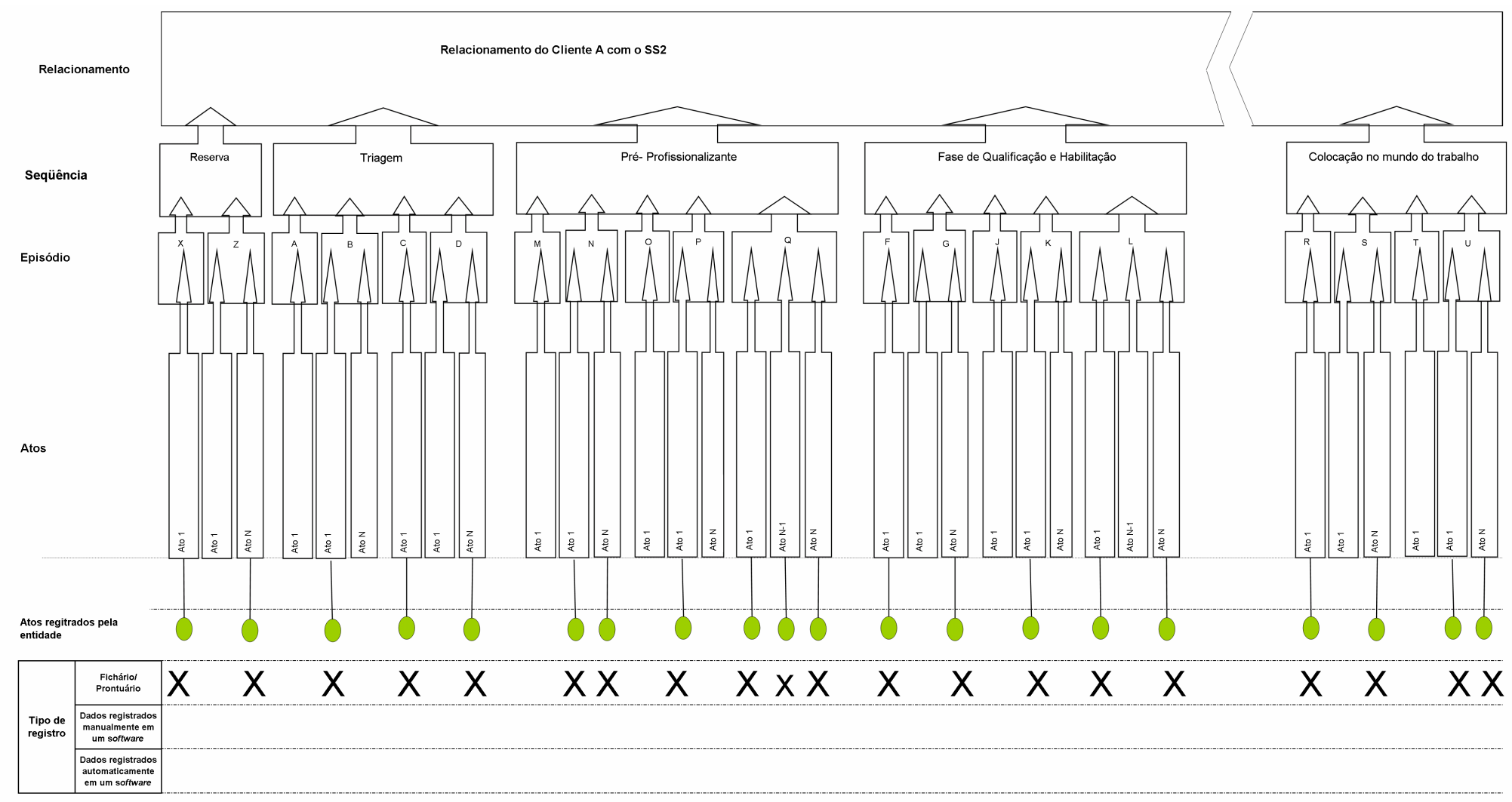

12 meses

12 meses

FIGURA 5.5 - Mapa de relacionamento para os cursos de aperfeiçoamento profissional para inserção social no mundo do trabalho Fonte: Pesquisa do autor, 2007. 
Uma análise do Mapa de Relacionamento exposto na Figura 5.5 revela as principais características das práticas de acompanhamento das atividades realizadas pelo jovem no caso SS2. Grande quantidade de atos é registrada pelo sistema através de formulários, relatórios, exames e prontuários utilizados nas atividades clínicas e nas demais atividades avaliativas. A maior parte da informação coletada refere-se a laudos clínicos e informações de caráter mais abrangente com um certo grau de detalhamento.

\subsubsection{Segunda fase - Análise dos dados e tomada de ações}

Existem várias rotinas para avaliar as atividades realizadas no Nepro durante as fases pré-profissionalizante e de qualificação e habilitação:

- Semanalmente, nas quartas-feiras, toda a equipe do Nepro realiza uma reunião para discussão dos itens mais críticos da semana que podem contemplar tópicos como problemas existentes nas oficinas, a evolução dos jovens, a necessidade de encaminhamento de alguns deles a uma atividade clínica específica, entre outras;

- Semanalmente, nas segundas-feiras seguintes às reuniões de quartasfeiras, faz-se uma reunião dos coordenadores de áreas para discussão e acompanhamento das atividades e planos de ação realizados, em função das deliberações das reuniões semanais de quarta-feira e da rotina diária;

- periodicamente, também são realizadas reuniões específicas, por exemplo, a reunião apenas do corpo clínico para discussão de tópicos específicos;

- cada atendimento clínico segue uma rotina específica de monitoramento que é registrada no prontuário do jovem; 
- existem relatórios trimestrais referentes ao desempenho do jovem nas oficinas. Avaliam-se aspectos como iniciativa, pontualidade, ritmo, atenção, concentração e assiduidade;

- há relatórios semestrais que analisam a evolução geral dos jovens;

- ao final de cada fase, é feito, também, um relatório de cada jovem, no qual se dá um laudo final;

- existem também reuniões semestrais com os pais, em que as atividades realizadas são apresentadas e as dúvidas dos pais são esclarecidas.

Durante a fase de colocação do jovem no mundo do trabalho, as seguintes rotinas de avaliação são realizadas:

- quando é identificada uma função que poderá ser preenchida por jovens do Nepro, os profissionais do caso SS2 realizam uma seleção interna procurando conciliar o potencial de desempenho do jovem e seu interesse pelo cargo com o perfil demandado pela empresa contratante;

- o jovem que for selecionado para o preenchimento desta posição recebe um acompanhamento bem próximo da equipe do Nepro. Acompanha-se sua inscrição e seu cadastramento na empresa contratante. Analisa-se seu engajamento no trabalho, as atividades de seu trabalho e seu entrosamento com os colegas. Com o passar do tempo, a freqüência de acompanhamento vai diminuindo (o que era diário passa a ser semanal, de semanal a mensal, de mensal a bimestral, etc.);

- faz-se o acompanhamento do jovem junto à sua família, para que implicações como controle financeiro dos rendimentos do jovem, cuidados no manuseio do dinheiro e/ou uso de cartão magnético, entre outros, possam ser bem inseridas no contexto da vida familiar.

\subsubsection{Táticas que estimulam o envolvimento e a participação dos clientes}

1) Educação e treinamento do cliente para a realização das atividades. 
- Esta é a própria atividade-fim da entidade.

2) Realização de atividades que promovem a socialização dos clientes

- São realizadas festas e outros eventos como a promoção do lançamento de um livro de poesias feitas pelos jovens em que a comunidade é convidada. O caso SS2 também promove intercâmbio com jovens de outras escolas.

3) Compensações e/ou prêmios por maior envolvimento e participação do cliente nas atividades.

- O caso SS2 não adota esta prática.

4) Estabelecimento de regras de condutas e/ou comportamento.

- O caso SS2 estabeleceu regras de comportamento - apresentadas no Anexo B - juntamente com os jovens, por meio de um "Trabalho de Roda". Emite-se uma advertência no caso de transgressão das normas e, no caso de reincidências, a terceira advertência poderá implicar na expulsão do jovem do programa.

5) Oferecimento de algum tipo de suporte para a realização das atividades.

- Estas atividades são realizadas durante a execução do serviço. Nesta direção, o caso SS2 ainda oferece encaminhamentos clínicos, caso necessário.

6) Envolvimento do cliente no planejamento/definição das atividades.

- Procura-se envolver o jovem no planejamento das atividades diárias. Adotam-se várias práticas que objetivam promovem o empoderamento do jovem.

7) Conscientização da importância do adequado cumprimento das atividades sob a responsabilidade do cliente.

- Os ex-alunos que concluíram o curso e estão trabalhando são convidados a dar testemunhos das atividades que estão realizando. Empresas conveniadas são visitadas pelos alunos. Estas atividades visam despertar o interesse pelo mundo do trabalho e mostrar as rotinas corporativas existentes permitindo que os jovens compreendam a 
importância do cumprimento de rotinas semelhantes em algumas atividades presentes na fase de qualificação e habilitação.

\subsection{CASO 5: CURSO PREPARATÓRIO PARA CONCURSO DE VESTIBULAR (CP1)}

\subsubsection{Caracterização da empresa}

O quinto caso de SRU considerado é o de um curso preparatório de alunos para concursos de vestibular (CP1). Trata-se do serviço oferecido por uma unidade franqueada de uma grande rede de ensino que existe na cidade de Contagem desde 2000. O caso CP1 tem a capacidade de atender cerca de 700 alunos por turno, mas acolhe entre 800 e 900, no total. Funciona em três turnos: Manhã (07h15 às 12h40), Tarde (14h às 18h15) e Noite (19h às 22h). Além das aulas propriamente ditas, presta vários outros serviços de suporte ou reforço. São exemplos destes serviços: aulas extras, plantões, núcleo de psicologia, monitorias, curso de aperfeiçoamento em disciplinas específicas, curso básico em matemática e/ou português.

\subsubsection{Coleta de dados}

Este estudo de caso foi conduzido por meio de uma entrevista semiestruturada com o diretor de ensino do caso CP1. Foram também consultados relatórios internos, folhetos promocionais e instruções referentes à matrícula e conduta dos alunos em sala de aula. 


\subsubsection{Processo de entrega do serviço}

De um modo geral, o oferecimento dos cursos divide-se em três fases distintas.

A primeira fase inicia-se no final do semestre, quando o departamento de marketing, que é terceirizado, analisa o perfil dos alunos do período anterior. Além disso, o caso CP1 faz uma grande avaliação geral do curso, envolvendo todos os seus alunos e funcionários. A partir destas análises, planeja a campanha do próximo semestre. Este plano de campanha define aspectos como: preço, processo de atendimento ao aluno, tipos de desconto que serão oferecidos, alterações de contrato que serão efetuadas e inovações didáticas que serão apresentadas aos alunos.

A segunda fase consiste no período de matrícula, que se inicia um mês antes do início das aulas. Vários funcionários são envolvidos nesta atividade. Como um meio de incentivar maior participação dos colaboradores, a organização lança um programa de gratificação por produtividade. No ato da matrícula, o aluno escolhe o tipo de curso (intensivo/extensivo) e os adicionais a esse curso. No contrato são explicitadas, principalmente, as situações de cancelamento da matricula previstas.

A terceira fase consiste na ministração das aulas propriamente ditas. Duas vezes por semestre o caso CP1 aplica uma avaliação simulando a resolução da prova de vestibular da Universidade Federal de Minas Gerais (UFMG). A simulação tenta reproduzir vários aspectos que caracterizam este vestibular, ou seja, layout da prova, duração, pontuação, regras de correção e sistema de fiscalização. As aulas terminam um dia antes do principal vestibular oferecido no semestre. A freqüência do aluno é monitorada por um sistema de catraca eletrônica. Caso o aluno chegue atrasado por mais de 15 minutos, deverá aguardar o intervalo antes da próxima aula para entrar na sala. 


\subsubsection{Sistema de monitoramento e controle dos clientes}

\subsubsection{Primeira fase - Procedimentos de seleção e de diagnóstico}

O caso CP1 não adota a prática de seleção de seus alunos. Antigamente, adotava a prática do "Bolsão", que consistia na realização de uma prova geral para toda a comunidade interessada, e os participantes dessa prova recebiam descontos na matrícula e/ou na mensalidade de acordo com sua classificação. Atualmente, o sistema de concessão de bolsas acontece de outra forma no caso CP1. Após a aplicação do primeiro exame simulado, os alunos com as melhores notas recebem bolsas e, em cada disciplina, o professor oferece prêmios/brindes para os melhores das turmas que leciona.

O caso CP1 não adota uma rotina de diagnóstico do cliente.

\subsubsection{Segunda fase - Atividades de monitoramento}

Com base na estrutura conceitual de Grönroos (2003) e Holmlund (1997; 2004), pode-se entender que o relacionamento dos alunos com caso CP1, como clientes, abrange vários episódios que se sucedem ao longo de um determinado curso. Assim, neste relacionamento, um curso como um todo constitui uma seqüência. A evolução do processo de serviço ao longo de um determinado curso é ilustrada pelo Mapa de Relacionamento apresentado na Figura 5.6 que considera a realização de um curso intensivo de seis meses. Este mapa também indica como diversos tipos de interação com alunos são registrados pelo sistema de monitoramento implementado. 


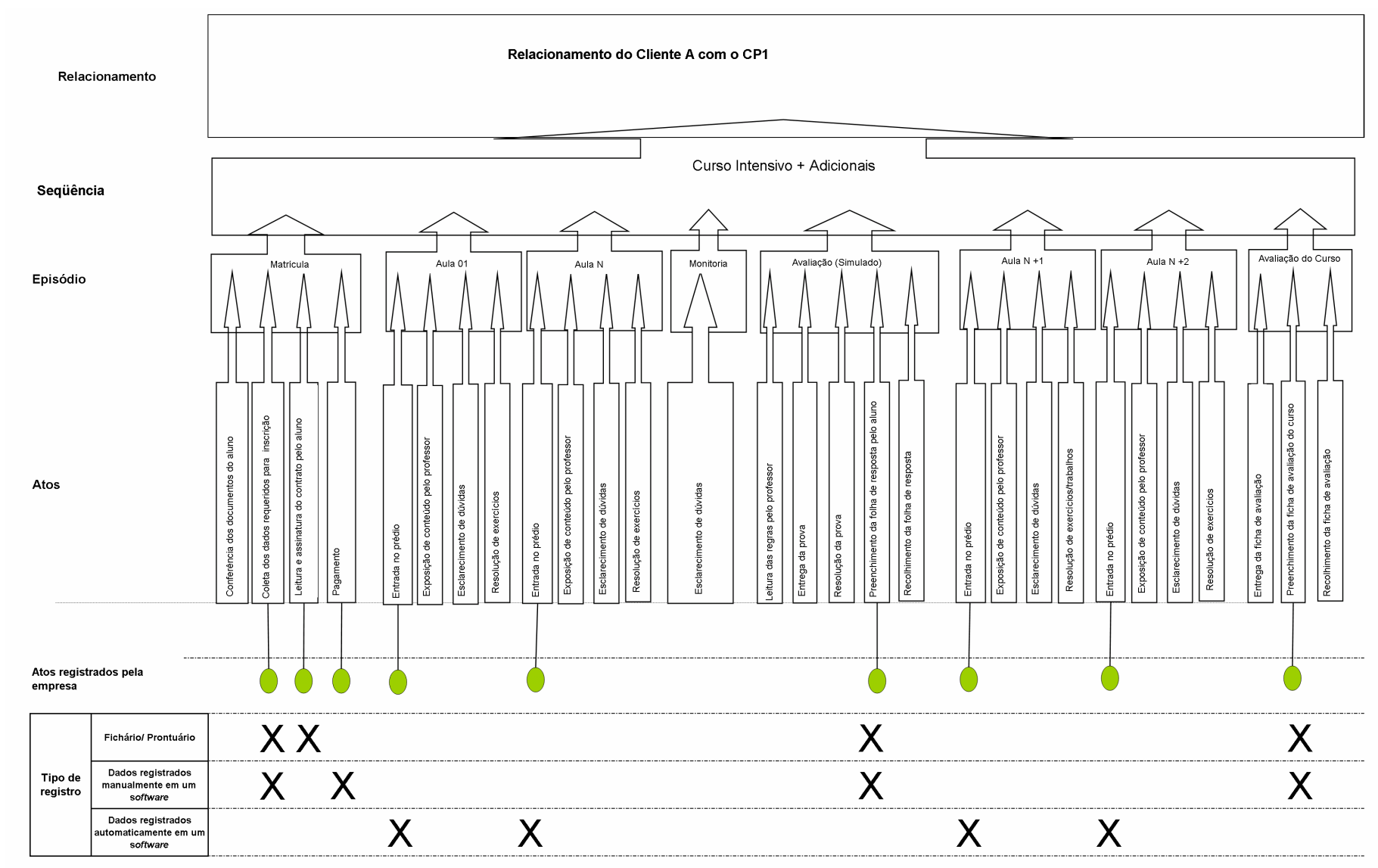

Tempo de 6 meses

FIGURA 5.6 - Mapa de relacionamento para o curso preparatório para concurso de vestibular

Fonte: Pesquisa do autor, 2007. 
Uma análise do Mapa de Relacionamento exposto na Figura 5.6 revela as principais características das práticas de acompanhamento das atividades realizadas pelo cliente no caso CP1. Alguns atos são registrados pelo sistema através de formulários e/ou lançados em um sistema informatizado. A maior parte da informação coletada refere-se a informações pontuais, tais como freqüência do aluno, nota obtida no exame simulado, etc.

De uma maneira mais detalhada, a estrutura de relacionamento pode ser descrita em seus diferentes níveis como no Quadro 5.6.

\begin{tabular}{|c|c|c|c|c|c|}
\hline Nível & \multicolumn{5}{|c|}{ Atividades } \\
\hline Seqüência & \multicolumn{5}{|c|}{$\begin{array}{l}\text { Curso } \\
\text { Pode ser Intensivo ( } 6 \text { meses) ou Extensivo (12 meses) } \\
\text { Existem cursos adicionais: Curso de Aperfeiçoamento em Disciplina Específica, Curso Básico em Matemática } \\
\text { ou Português }\end{array}$} \\
\hline Episódio & Matrícula & Aulas & Monitoria & $\begin{array}{l}\text { Avaliação (Exame } \\
\text { simulado) }\end{array}$ & $\begin{array}{l}\text { Avaliação do Curso } \\
\text { ( realizada ao final } \\
\text { do semestre, } \\
\text { verifica-se se as } \\
\text { expectativas dos } \\
\text { alunos foram } \\
\text { atendidas ou não) }\end{array}$ \\
\hline $\begin{array}{l}\text { Principais } \\
\text { atos }\end{array}$ & \begin{tabular}{|ll}
- & $\begin{array}{l}\text { Conferência dos } \\
\text { documentos do }\end{array}$ \\
& aluno \\
- & Coleta dos dados \\
& requeridos para \\
inscrição \\
$-\quad$ & Leitura e \\
& assinatura do \\
& contrato pelo \\
- & aluno \\
Pagamento
\end{tabular} & \begin{tabular}{|ll}
- & Chamada \\
- & Exposição de \\
& conteúdo pelo \\
& professor \\
- & Esclarecimento \\
& de dúvidas \\
- & Resolução de \\
& exercícios \\
& pelos alunos
\end{tabular} & $\begin{array}{ll}\text { - } & \text { Esclarecimento } \\
\text { de dúvidas }\end{array}$ & $\begin{array}{ll}- & \text { Leitura das } \\
& \text { regras pelo } \\
\text { professor } \\
\text { - } & \text { Entrega da } \\
\text { prova } & \text { Resolução da } \\
- & \text { prova } \\
-\quad \text { Preenchimento } \\
\text { da folha de } \\
\text { resposta pelo } \\
\text { aluno } \\
\text { Recolhimento } \\
\text { da folha de } \\
\text { resposta }\end{array}$ & 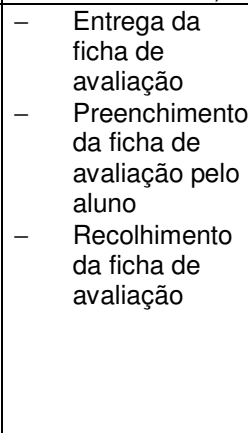 \\
\hline
\end{tabular}

QUADRO 5.6 - Atividades registradas pelo curso preparatório para o vestibular Fonte: Pesquisa do autor, 2007.

\subsubsection{Segunda fase - Análise dos dados e tomada de ações}

A freqüência dos dados é monitorada sendo verificada mensalmente. Os alunos que apresentam um índice de freqüência inferior a 75\% são encaminhados ao diretor do caso CP1, que procura entender a causa e ajudá-los. 
Após cerca de uma semana da aplicação do exame simulado ${ }^{27}$, o caso CP1 seleciona os alunos que apresentaram um rendimento inferior a $30 \%$ no global e/ou que acertaram, no máximo, duas das oito questões de cada matéria. Eles são encaminhados ao diretor da unidade, que tenta entender as razões do baixo rendimento, e busca auxiliá-los a melhorar seu desempenho. Para isso, normalmente, faz as seguintes orientações: i) que o aluno freqüente mais as monitorias; ii) que seja mais freqüente às aulas; iii) que mude de posição de carteira, em sala de aula, para melhor acompanhar às aulas; iv) que melhore o planejamento do horário de estudo ou que freqüente as salas de estudo da unidade.

Para evitar uma excessiva comparação ou competição entre os alunos, as notas das provas simuladas são fornecidas por meio de código individual, de tal maneira que apenas o aluno que realizou a prova consiga saber a sua nota.

A eficácia dos serviços é verificada pelo exame de vestibular. Dois funcionários da empresa examinam nas listas de aprovações publicadas pelos meios de divulgação das faculdades e universidades, a relação dos alunos aprovados que fizeram o curso preparatório CP1.

\subsubsection{Táticas que estimulam o envolvimento e a participação dos clientes}

1) Educação e treinamento do cliente para a realização das atividades.

- As atividades se referem à formação e à educação em si.

2) Realização de atividades que promovem a socialização dos clientes.

- Não são feitas atividades neste sentido.

3) Compensações e/ou prêmios por maior envolvimento e participação do cliente nas atividades.

- O caso CP1 não adota esta prática.

4) Estabelecimento de regras de condutas e/ou comportamento.

\footnotetext{
${ }^{27} \mathrm{O}$ exame simulado consiste de oito provas, uma para cada matéria (Português, Matemática, Física, Química, Biologia, História, Geografia e Inglês ou Espanhol). Cada prova contém oito questões.
} 
- O caso CP1 estabelece regras de comportamento. Elas são apresentadas no Anexo C.

5) Oferecimento de algum tipo de suporte para a realização das atividades.

- É oferecida monitoria para todas as matérias. Além disso, a organização disponibiliza cursos adicionais que se destinam a um aprofundamento maior em matérias específicas. Há ainda um curso básico para aqueles que possuem dificuldades em disciplinas como matemática e português, com o intuito de reforçar sua aprendizagem para o concurso de vestibular. O caso CP1 mantém ainda um núcleo de psicologia para orientar os alunos que necessitam de um apoio desta natureza.

6) Envolvimento do cliente no planejamento/definição das atividades.

- A avaliação do curso realizada individualmente pelo aluno, no final do semestre, é utilizada para elaborar a próxima campanha do curso.

7) Conscientização da importância do adequado cumprimento das atividades sob a responsabilidade do cliente.

- Assuntos relacionados à freqüência, tempo de estudo, empenho, normas disciplinares são fixadas no mural. Na primeira semana de aula, esses assuntos são introduzidos, em sala de aula, pela própria direção.

\subsection{CASO 6: CURSO PREPARATÓRIO PARA CONCURSOS EM CARREIRAS DO DIREITO (CP2)}

\subsubsection{Caracterização da empresa}

O sexto caso refere-se a uma empresa que oferece cursos preparatórios para concursos públicos em carreiras do direito (CP2), tais como defensor público, delegado de polícia, juiz substituto, magistraturas federal, estadual e trabalhista, procurador do Estado e promotor de justiça. Adicionalmente, o caso CP2 
disponibiliza cursos de reciclagem jurídica e de especialização que existe desde 1991. Trata-se de uma empresa pioneira nessa área.

Seu grande público é constituído por alunos de direito (aqueles que se situam na fase final do curso), advogados e funcionários públicos.

Além das aulas, a empresa oferece serviços como informações sobre concursos jurídicos em todo o Brasil; terminais com acesso livre à Internet; acompanhamento da legislação federal, com repasse das modificações de interesse; sistema de consulta da legislação federal, via computador; biblioteca jurídica; ambiente para estudo em grupos e cabines para estudo individual; inscrições por procuração em concursos jurídicos; resolução de dúvidas por e-mail; excursões para execução de provas em locais distantes; e testes simulados on-line.

\subsubsection{Coleta de dados}

O estudo de caso foi conduzido por meio de uma entrevista semi-estruturada à supervisora pedagógica. Foram também consultados relatórios internos e folders promocionais do curso. Dentre os serviços oferecidos pela empresa, apenas os cursos de preparação para concursos em carreiras do direito foram analisados. Tratam-se de cursos cujo período de preparação dos alunos se estende, normalmente por 5-6 meses e podem ser enquadrados como SRU.

\subsubsection{Processo de entrega do serviço}

De uma maneira geral, três fases distintas para o oferecimento dos cursos podem ser identificadas. A primeira delas consiste na captação de alunos e sua matrícula. O caso CP2 capta alunos por dois modos. No primeiro modo, os alunos procuram o curso porque tomaram conhecimento dele por recomendações de outros 
colegas ou profissionais do meio jurídico. O segundo modo consiste nos meios promocionais tradicionais de marketing. Existe uma divulgação por meio de materiais promocionais distribuídos nos diferentes cursos de direito existentes na cidade de Belo Horizonte e nas instituições jurídicas (fóruns existentes no Estado, Ministério Público, tribunais de justiça, tribunais eleitorais). O site do caso CP2 na world wide web (www) também oferece informações sobre os cursos oferecidos. Materiais publicitários são também enviados por meio de mala direta. No ato da matrícula, o aluno escolhe o curso sob a orientação dos funcionários e assina o contrato e já emite os cheques referentes a todas as parcelas do curso.

A segunda fase consiste na ministração das aulas propriamente ditas. Os cursos têm normalmente uma duração de cinco a seis meses. Para fins de treino, os alunos têm a opção de realizar até dois exames simulados. Estes testes procuram reproduzir vários aspectos que caracterizam o exame nos concursos, tais como layout da prova, duração, pontuação, regras de correção e sistema de fiscalização. A freqüência dos alunos é monitorada, e a emissão do certificado depende de uma freqüência mínima de 75\%. Duas avaliações do curso são feitas pelos alunos, uma durante sua execução e outra no final.

A terceira fase consiste na verificação das aprovações dos alunos que freqüentarem algum curso do caso CP2 e prestaram concursos. Isso é realizado pela Central de Concursos. Esta também monitora a divulgação pública da realização de concursos e disponibiliza demais informações relacionadas (editais, provas anteriores e materiais de estudo).

\subsubsection{Sistema de monitoramento e controle dos clientes}

\subsubsection{Primeira fase - Procedimentos de seleção e de diagnóstico}

O caso CP2 não adota a prática de seleção de clientes. Antigamente, porém, adotava-se a prática do "Bolsão", que consistia na realização de uma prova geral 
para toda a comunidade interessada, e os participantes recebiam descontos na matrícula e/ou na mensalidade de acordo com a sua classificação. Atualmente, o sistema de concessão de bolsas segue outro critério: após a aplicação do primeiro exame simulado, os alunos que alcançaram as melhores notas recebem bolsas.

Não há uma rotina de diagnóstico estabelecida pelo caso CP2.

\subsubsection{Segunda fase - Atividades de monitoramento}

Assim como nos cinco estudos de caso anteriores, o relacionamento da empresa com seus clientes no caso CP2 pode ser analisado à luz da estrutura conceitual de Grönroos (2003) e Holmlund (1997; 2004). No processo de serviço do caso CP2, observa-se que o sistema de monitoramento implementado registra diferentes tipos de atos em episódios variados. A estrutura do relacionamento com os clientes e o sistema implementado podem ser esquematizados conforme ilustra o Mapa de Relacionamento exposto na Figura 5.7 que considera a realização de um curso preparatório típico oferecido pelo caso CP2. 


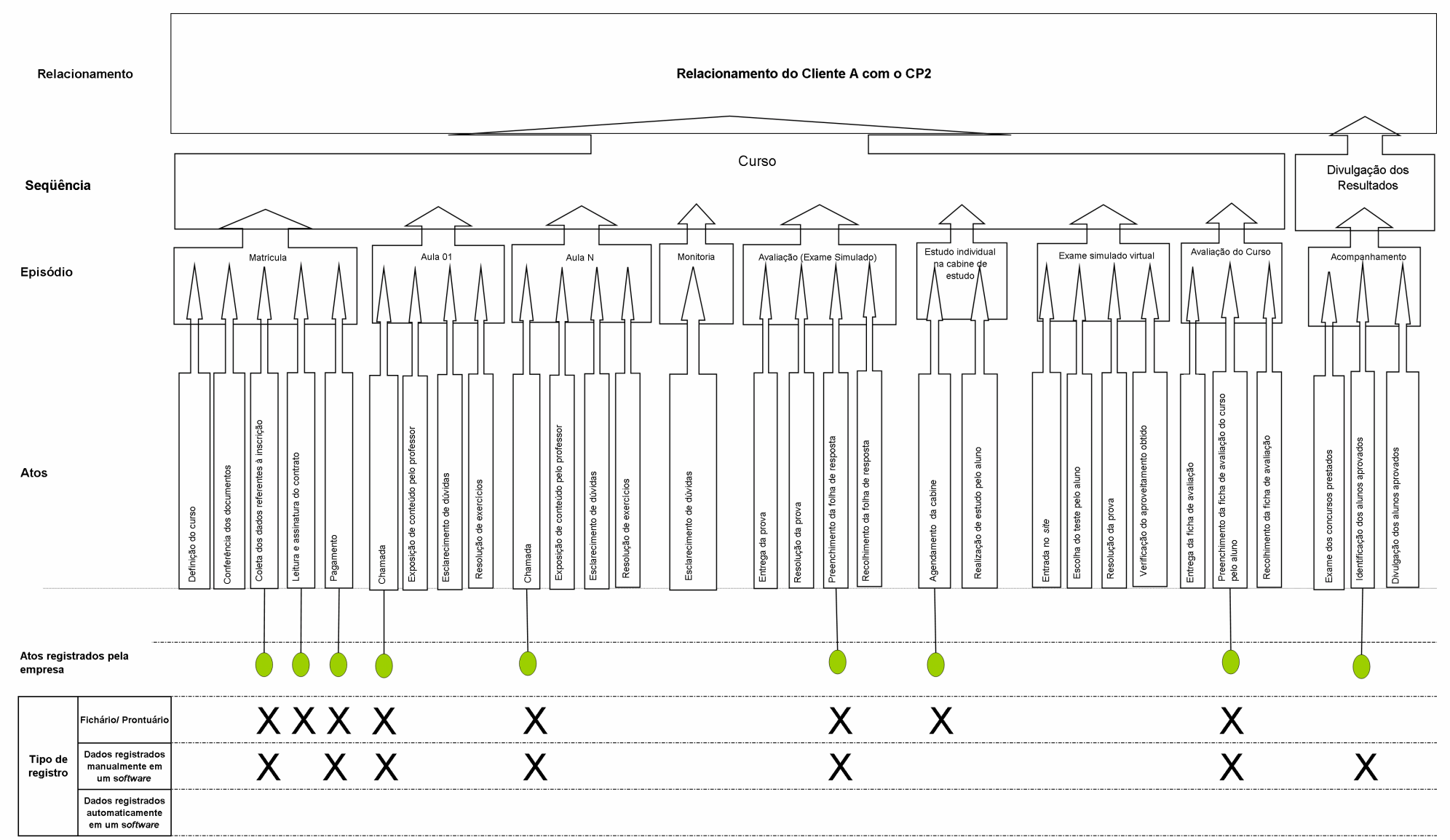

Tempo de 6 meses

FIGURA 5.7 - Mapa de relacionamento para os cursos preparatórios de candidatos para concursos em carreiras do direito Fonte: Pesquisa do autor, 2007. 
Uma análise do Mapa de Relacionamento exposto na Figura 5.7 revela as principais características das práticas de acompanhamento das atividades realizadas pelo cliente no caso CP2. Alguns atos são registrados pelo sistema através de formulários e/ou lançados em um sistema informatizado. A maior parte da informação coletada refere-se a informações pontuais, tais como freqüência do aluno, resultado final no concurso público (aprovação/reprovação), etc.

No decorrer do processo de realização de um curso, pode-se entender que a preparação do aluno evolui ao longo de uma série de episódios os quais, por sua vez, podem ser desdobrados em atos que ocorrem no dia a dia. De uma maneira mais detalhada, tal estrutura de relacionamento pode ser descrita em seus diferentes níveis como no Quadro 5.7.

\begin{tabular}{|c|c|c|c|c|c|c|c|c|c|c|}
\hline Nível & \multicolumn{10}{|c|}{ Atividade } \\
\hline Seqüência & \multicolumn{9}{|l|}{ Curso } & $\begin{array}{l}\text { Divulgação dos } \\
\text { Resultados }\end{array}$ \\
\hline Episódio & Matrícula & Aula & $\begin{array}{l}\text { Estudo } \\
\text { individual } \\
\text { na cabine } \\
\text { de estudo }\end{array}$ & Monitoria & $\begin{array}{l}\text { Simulado } \\
\text { virtual }\end{array}$ & $\begin{array}{l}\text { Consulta/ } \\
\text { emprésti- } \\
\text { mos de } \\
\text { livros }\end{array}$ & $\begin{array}{l}\text { Devolução } \\
\text { do Livro } \\
\text { emprestado }\end{array}$ & $\begin{array}{l}\text { Simulado } \\
\text { presencial }\end{array}$ & $\begin{array}{l}\text { Avaliação } \\
\text { do Curso }\end{array}$ & $\begin{array}{l}\text { Acompanhamento das } \\
\text { classificações dos } \\
\text { alunos nos concursos } \\
\text { pela Central de } \\
\text { Concursos }\end{array}$ \\
\hline $\begin{array}{c}\text { Principais } \\
\text { Atos }\end{array}$ & $\begin{array}{l}\text { - Definição } \\
\text { do curso } \\
\text { Conferência } \\
\text { dos } \\
\text { documen- } \\
\text { tos (caso } \\
\text { seja } \\
\text { funcionário } \\
\text { público ou } \\
\text { estudante } \\
\text { de direito) } \\
\text {-Coleta dos } \\
\text { dados } \\
\text { referentes à } \\
\text { inscrição } \\
\text {-Leitura e } \\
\text { assinatura } \\
\text { do contrato } \\
\text { Pagamento }\end{array}$ & $\begin{array}{l}\text { - Chamada } \\
\text { - Exposição } \\
\text { de } \\
\text { conteúdo } \\
\text { pelo } \\
\text { professor } \\
\text { - Esclareci- } \\
\text { mento de } \\
\text { dúvidas } \\
\text { - Resolução } \\
\text { de } \\
\text { exercícios } \\
\text { pelos } \\
\text { alunos }\end{array}$ & $\begin{array}{l}\text { - Agenda- } \\
\text { mento da } \\
\text { cabine } \\
\text { Realização } \\
\text { de estudo } \\
\text { pelo aluno }\end{array}$ & $\begin{array}{l}\text { - Esclareci- } \\
\text { mento de } \\
\text { dúvidas }\end{array}$ & $\begin{array}{l}\text { - Entrada } \\
\text { no site } \\
\text { - Escolha } \\
\text { do teste } \\
\text { pelo aluno } \\
\text { - Resolução } \\
\text { da prova } \\
\text { - Verificação } \\
\text { do } \\
\text { aproveita- } \\
\text { mento } \\
\text { obtido }\end{array}$ & $\begin{array}{l}\text { - Consulta } \\
\text { ao livro } \\
\text { - Emprésti- } \\
\text { mo }\end{array}$ & $\begin{array}{l}\text { - Devolução } \\
\text { do livro pelo } \\
\text { aluno }\end{array}$ & $\begin{array}{l}\text { - Entrega } \\
\text { da prova } \\
\text { - Resolução } \\
\text { da prova } \\
\text { - Preenchi- } \\
\text { mento da } \\
\text { folha de } \\
\text { resposta } \\
\text { pelo aluno } \\
\text { Recolhimen } \\
\text {-to da folha } \\
\text { de resposta }\end{array}$ & $\begin{array}{l}\text { - Entrega } \\
\text { da ficha de } \\
\text { avaliação } \\
\text { - Preenchi- } \\
\text { mento da } \\
\text { ficha de } \\
\text { avaliação } \\
\text { pelo aluno } \\
\text { - Recolhi- } \\
\text { mento da } \\
\text { ficha de } \\
\text { avaliação }\end{array}$ & $\begin{array}{l}\text { - Exame dos concursos } \\
\text { realizados } \\
\text { - Identificação dos } \\
\text { alunos aprovados } \\
\text { - Divulgação dos alunos } \\
\text { aprovados }\end{array}$ \\
\hline
\end{tabular}

QUADRO 5.7 - Atividades realizadas pelo curso preparatório para carreiras em direito Fonte: Pesquisa do autor, 2007.

\subsubsection{Segunda fase - Análise dos dados e tomada de ações}

Segundo a supervisora pedagógica da empresa CP2 não é necessário dedicar-se uma análise criteriosa da freqüência ou das notas obtidas pelos alunos nos exames simulados, pois eles são muito exigentes com seu próprio desempenho, sendo que vários deles deixam de trabalhar para se dedicar exclusivamente à preparação para os concursos. Portanto, a organização deixa a cargo dos próprios 
clientes a verificação e julgamento de seu desempenho e a tomada de ações para sua melhoria. Na evidência de um baixo rendimento, geralmente, os próprios alunos procuram os professores, solicitando orientações.

Os alunos realizam duas avaliações gerais sobre o curso. A primeira é aplicada em torno de dois meses e meio após o início das aulas, e a segunda no final do curso. Este tipo de avaliação é necessário para verificar se o feedback do professor às dúvidas apresentadas tem sido adequado. Estas avaliações também contemplam aspectos gerais sobre o professor, a disciplina, o apoio e a infraestrutura oferecidos. A partir dos dados levantados destas avaliações, o curso poderá ser reformulado.

Os exames simulados são avaliados de uma maneira global. Verifica-se o nível geral de desempenho da turma e procura-se identificar os temas em que os alunos estejam enfrentando maior dificuldade de aprendizagem. A partir desta análise, a empresa poderá reforçar o curso nas áreas onde houver as maiores carências ou dificuldades.

A eficácia dos resultados alcançados pelos alunos nos serviços é verificada por meio de concursos públicos, conferindo-se a relação dos aprovados. Mesmo que o aluno não esteja mais presente no caso CP2, o seu nome continua registrado em seu sistema e, a cada novo concurso público, confere-se a sua presença na lista de aprovações.

\subsubsection{Táticas que estimulam o envolvimento e a participação dos clientes}

1) Educação e treinamento do cliente para a realização das atividades.

- As atividades se referem à formação e educação em si.

2) Realização de atividades que promovem a socialização dos clientes.

- São promovidas festas de confraternização para gerar um entrosamento maior entre alunos e professores. Essas atividades objetivam também 
amenizar o clima de rivalidade existente entre alguns alunos, principalmente no início do curso.

3) Compensações e/ou prêmios por maior envolvimento e participação do cliente nas atividades.

- O caso CP2 não adota esta prática.

4) Estabelecimento de regras de condutas e/ou comportamento.

- Há regras de comportamento no que se refere à conduta dos alunos em sala de aula e no uso dos recursos oferecidos (biblioteca e cabine de estudo).

5) Oferecimento de algum tipo de suporte para a realização das atividades.

- O caso CP2 oferece vários tipos de suporte: monitoria; salas de estudo; esclarecimento de dúvidas por e-mail; exames simulados on-line; terminais com acesso livre à Internet; guarda-volumes; acompanhamento da legislação federal, com repasse das modificações de interesse; e sistema de consulta da legislação federal via computador. Para a participação de alunos em concursos, a empresa oferece serviço de inscrição por meio de procuração, e organiza excursões para realização de provas em locais distantes.

6) Envolvimento do cliente no planejamento/definição das atividades.

- As duas avaliações do curso realizadas pelo aluno durante o curso são consideradas para ajustar o curso em andamento (primeira avaliação) e modificar o próximo (segunda avaliação).

7) Conscientização da importância do adequado cumprimento das atividades sob a responsabilidade do cliente.

- Faz parte do papel dos professores do curso explicar a dinâmica de preparação para os concursos. Eles explicam quais atitudes e práticas são recomendáveis para se alcançar um bom aproveitamento. Alguns exalunos que passaram em concursos são convidados a dar o seu testemunho sobre sua preparação e dificuldades enfrentadas. O próprio site do caso CP2 divulga vários relatos de ex-alunos, no sentido de incentivar, motivar e educar os atuais alunos. 


\subsection{DESEMPENHO DOS SERVIÇOS ANALISADOS}

Inicialmente, para cada caso, será explicado o método utilizado para o cálculo dos indicadores: freqüência, taxa de retenção e eficácia dos serviços.

\subsubsection{AC1 - Academia de ginástica - atividades de musculação}

Para medir esses indicadores, a empresa $A C 1$ escolheu o mês de junho de 2006 como referência. Nesse mês, em média, os alunos freqüentaram a academia quatro vezes por semana (quatro dias em seis disponíveis). Isso corresponde a uma freqüência em torno de $67 \%$.

No referido período, 57 pessoas teriam de realizar a reavaliação, mas apenas 37 continuavam freqüentando a academia ( 37 das 57 consideradas permaneceram no trimestre de abril até junho de 2006 na academia). Isso resultou numa taxa de retenção em torno de $65 \%$ (37/57).

Das 37 pessoas que deveriam fazer a reavaliação no referido mês, apenas 10 compareceram. Dos 10 alunos que fizeram a reavaliação, 8 atingiram sua meta, sendo que destes 3 tinham como objetivo hipertrofia, e os 5 restantes, emagrecimento. Isso representa uma taxa de eficácia de $80 \%(8 / 10)$, dentre aqueles que fizeram a reavaliação.

Apesar do caso AC1 ter um sistema informatizado para registro dessas informações, como exposto anteriormente, ela não emite relatórios periódicos sobre estes indicadores. 


\subsubsection{AC2 - Grande academia de ginástica - atividades de musculação}

Os dados do caso AC2 foram obtidos a partir do software utilizado para realizar parte das atividades de monitoramento. A freqüência dos alunos varia conforme o horário. No final da manhã e na parte da tarde a freqüência é maior do que a nos horários de pico. Isso ocorre porque o público é diferente. No final da manhã e na parte da tarde o clube é freqüentado, em grande parte, por estudantes e aposentados, que normalmente dispõem de maior tempo livre. A freqüência média na musculação é de 53,6\%. A mínima gira em torno de 35\% e a máxima em torno de $70 \%$.

A taxa de retenção foi estimada através da taxa de cancelamento trimestral em 2006, obtida de uma base inicial de 720 pessoas matriculadas. Destas, após os três primeiros meses, 122 pessoas haviam evadido e 598 continuavam matriculadas. Isso indica uma taxa de retenção em torno de $83 \%$ (598/720) no período considerado. A empresa AC2 também forneceu as taxas de cancelamentos após seis, nove e doze meses. A Tabela 5.1 mostra estes valores.

TABELA 5.1 - Taxas de Cancelamento e Retenção para a Grande Academia de Ginástica

\begin{tabular}{|c|c|c|c|c|}
\hline Período & 1 은 Trimestre & 2o Trimestre & 3ㅇ Trimestre & 4은 Trimestre \\
\hline Matriculados & 720 & 598 & 517 & 483 \\
\hline Evasão no trimestre & 122 & 81 & 26 & 8 \\
\hline $\begin{array}{l}\text { Taxa de Cancelamento (\% em } \\
\text { relação ao número de } \\
\text { matriculados no trimestre) }\end{array}$ & $17 \%$ & $14 \%$ & $5 \%$ & $2 \%$ \\
\hline $\begin{array}{l}\text { Taxa de Retenção sobre } 720 \\
\text { alunos }\end{array}$ & $83 \%$ & $72 \%$ & $68 \%$ & $66 \%$ \\
\hline
\end{tabular}

Fonte: Pesquisa do autor, 2006.

O trabalho de Zanette (2003) aponta que cerca $70 \%$ das pessoas que freqüentam as academias já mudaram de academia pelo menos uma vez. Isso indica como a baixa capacidade de retenção é um grande problema no setor. Uma análise comparativa entre as duas empresas de academia estudadas no presente 
trabalho indica que o caso AC2 apresenta uma capacidade de retenção superior ao caso AC1.

De uma turma de 100 clientes, 60 deles se dispunham a conquistar objetivos tais como emagrecimento, hipertrofia, etc. Destes, 33 atingiram sua meta quando realizaram o exame funcional. Isso indica uma taxa de eficácia em torno de 55\% $(33 / 60)$.

\subsubsection{SS1 - Cursos de aperfeiçoamento profissional para recolocação e reinserção social}

Para medir os indicadores referentes a este caso, foram utilizados os dados do ano de 2005. Ao final de cada ano, o caso SS1 faz um balanço de suas atividades e, com base nesse balanço, planeja as atividades para o próximo ano.

A coordenação da entidade SS1 informou que a freqüência dos alunos em seus cursos se situa entre $90 \%$ e $100 \%$ de presença. Como já exposto anteriormente, esta entidade exige uma freqüência mínima de 90\% para emissão de certificados. Considerou-se que a freqüência média situa-se próxima do valor médio desta faixa, ou seja, 95\% para os alunos que concluíram o curso.

A partir dos dados do Quadro 5.4, estimou-se a taxa de retenção nos diferentes cursos. Das 620 pessoas que se inscreveram nas vagas oferecidas, 468 receberam o certificado. Isso resulta numa taxa de retenção média, medida na conclusão dos cursos, em torno de 75\% (468/620).

Os dados do Quadro 5.4 foram utilizados para estimar a eficácia do serviço. Das 365 pessoas que foram encaminhadas pelo caso SS1 para oportunidades de trabalho no ano de 2005, 169 foram empregadas. Isso indica uma taxa de eficácia em torno de $46 \%(169 / 365)$. 


\subsubsection{SS2 - Cursos de aperfeiçoamento profissional para inserção social no mundo do trabalho}

Para medir os indicadores referentes ao serviço prestado pelo Nepro da entidade SS2 foram utilizados principalmente os dados do relatório anual das atividades realizadas ano de 2005.

A entidade informou que a freqüência média em seus cursos se situa em torno de $95 \%$. Como já exposto anteriormente, esta entidade se preocupa não apenas com a freqüência de seus alunos, mas também com sua pontualidade.

Segundo o relatório, do total de 244 jovens admitidos pelo programa, em 2005, 2 foram desligados, 7 desistiram e 235 permaneceram durante todo o programa. Isso indica uma taxa de retenção em torno de 96\% (235/244). Além disso, o relatório informa que 6 alunos mantiveram seus estágios e 31 foram efetivados. Portanto, dos 235 que permaneceram durante todo o programa, 37 conseguiram uma colocação no mercado de trabalho formal. Isso indica uma taxa de eficácia em torno de $16 \%$ (37/235). Atualmente, o caso SS2 considera a possibilidade de empregar os alunos também no mercado informal de trabalho.

\subsubsection{CP1 - Curso preparatório para concurso de vestibular}

Para mensurar os indicadores referentes a este curso preparatório foram utilizados principalmente os relatórios internos. Foi importante ter acesso as fontes primárias de informação pois segundo o diretor da empresa entrevistada, os valores divulgados na mídia pelas empresas deste setor não são muito fidedignos.

$\mathrm{O}$ caso CP1 reportou que em suas turmas a freqüência média dos alunos se situa entre $70 \%$ e $75 \%$. Para fins do presente estudo, considerou-se como freqüência a média global, valor médio dessa faixa de $73 \%$. 
Uma análise dos relatórios revela a ocorrência de 134 cancelamentos em 1343 matrículas realizadas para o período considerado. Isso totaliza uma taxa de retenção em torno de 90\% (1209/1343).

Uma análise dos relatórios referentes ao ano de $2004^{28}$ aponta que houve 725 aprovações entre os 1209 alunos que permaneceram no curso, mas o número de aprovações é maior do que número de alunos aprovados, na medida em que um mesmo aluno pode ser aprovado em mais de um vestibular. Portanto para estimar a eficácia faz-se necessário calcular a quantidade de alunos que foram aprovados. Considerando a quantidade de alunos aprovados, o valor cai de 725 para 612. Isso indica uma taxa de eficácia em torno de 51\% (612/1209).

Adicionalmente é preciso esclarecer que se for considerado o número de aprovados apenas para as duas maiores universidades do Estado de Minas Gerais, Universidade Federal de Minas Gerais (UFMG) e Pontifícia Universidade Católica de Minas Gerais (PUC-MG), o percentual de eficácia é menor.

\subsubsection{CP2 - Curso preparatório para concursos em carreiras do direito}

A empresa CP2 informou que a freqüência média em seus cursos se situa entre $80 \%$ e $90 \%$ de presença. No turno da manhã, a freqüência média oscila em torno de $90 \%$ e, no turno da noite, em torno de $80 \%$. Como freqüência média nesta empresa considerou-se o valor médio desta faixa, de $85 \%$ de freqüência.

Já a taxa de retenção em seus cursos se situa entre $80 \%$ e $85 \%$. Considerouse que nesta empresa a taxa de retenção média situa-se no valor médio desta faixa, ou seja, cerca de $83 \%$.

Tomando-se como referência a aprovação dos alunos que realizaram um concurso logo em seguida à conclusão do curso, a taxa de eficácia se situa em torno

\footnotetext{
${ }^{28}$ Os dados sobre aprovações referentes a 2005 não foram fornecidos por serem ainda mantidos confidenciais.
} 
de $21 \%$. Como grande parte dos alunos continuam estudando por conta própria ${ }^{29}$, depois de concluírem o curso, a empresa mantém registro dos seus ex-alunos, e continua se os mesmos constam na lista dos candidatos aprovados nos novos concursos. Assim sendo, a taxa de eficácia pode ser analisada sob diferentes perspectivas temporais. Dentro desta ótica, tomando como base ex-alunos que já estejam registrados por dois anos no cadastro da empresa, a taxa de eficácia sobe para a faixa de $60 \%$ a $70 \%$. Obviamente, ao se tomar um horizonte de tempo maior, o valor deste indicador tende a aumentar mais ainda.

\subsubsection{Síntese da avaliação de indicadores de desempenho}

O desempenho no processo de serviço desenvolvido pelas empresas/entidades investigadas na pesquisa de campo foi avaliado por meio de indicadores de freqüência, taxa de retenção e eficácia. Os dados obtidos são sintetizados na Tabela 5.2 apenas para facilitar sua consulta e não para fins de comparação. Vale notar que - como será discutido no próximo capítulo - nem todos os dados tabulados podem ser conjuntamente comparados.

TABELA 5.2 - Resultados de desempenho nas diferentes empresas/entidades analisadas.

\begin{tabular}{|l|c|c|c|c|c|c|}
\hline \multicolumn{1}{|c|}{ Casos } & AC1 & AC2 & SS1 & SS2 & CP1 & CP2 \\
\hline Indicadores & & & & & & \\
\hline Taxa de Retenção & $67 \%$ & $54 \%$ & $90 \%$ & $95 \%$ & $73 \%$ & $85 \%$ \\
\hline Eficácia & $80 \%$ & $53 \%$ & $75 \%$ & $96 \%$ & $90 \%$ & $83 \%$ \\
\hline
\end{tabular}

Fonte: Pesquisa do autor, 2007.

\footnotetext{
${ }^{29}$ A empresa disponibiliza no seu site várias facilidades para esses alunos. Por exemplo: eles podem fazer exames simulados, consultar a disponibilidade de concursos e editais.
} 


\section{ANÁLISE E DISCUSSÃO DOS RESULTADOS}

Neste capítulo os resultados encontrados nos seis estudos de casos conduzidos em SRUs são analisados. Três tipos de análise conjunta são feitas. A primeira análise consiste na comparação intra-pares de casos. A segunda análise na consiste na comparação entre os pares de casos. Por último, é apresentada uma comparação entre entidades sem fins lucrativos e empresas que visam ao lucro.

\subsection{ANÁLISE INTRA-PARES DE CASOS}

\subsubsection{Casos AC1 e AC2}

Estes dois casos se referem ao serviço de atividades de musculação em academia de ginástica. Sob o ponto de vista de operação observa-se apenas uma diferença significativa entre os dois. Essa diferença se refere ao volume de processamento de clientes. Com relação a esta variável, o caso AC1 processa um volume menor de clientes se comparada ao caso AC2, entretanto, o grau de customização e discrição em seus processos se assemelham.

\subsubsection{Sistema de monitoramento e controle nas duas empresas}

Várias características e práticas propostas pelo sistema de monitoramento preconizado no framework teórico exposto na seção 3.5.1 foram observadas nas duas empresas. Pelo Gráfico 6.1, observa-se que algumas das rotinas de coleta e análise dos dados nas duas empresas se diferem. Apesar de ambas as empresas realizarem trimestralmente uma avaliação dos resultados ulteriores e dos fatores 
externos sob o controle do cliente, apenas um pequeno percentual de clientes realiza esta análise na empresa do caso $A C 1$. No que tange as atividades de correção e ajuste do processo de serviço, observou-se um cuidado maior por parte do caso AC2 nos itens 6, 7 e 9 avaliados.

\section{CARACTERÍSTICASI PRÁTICAS}

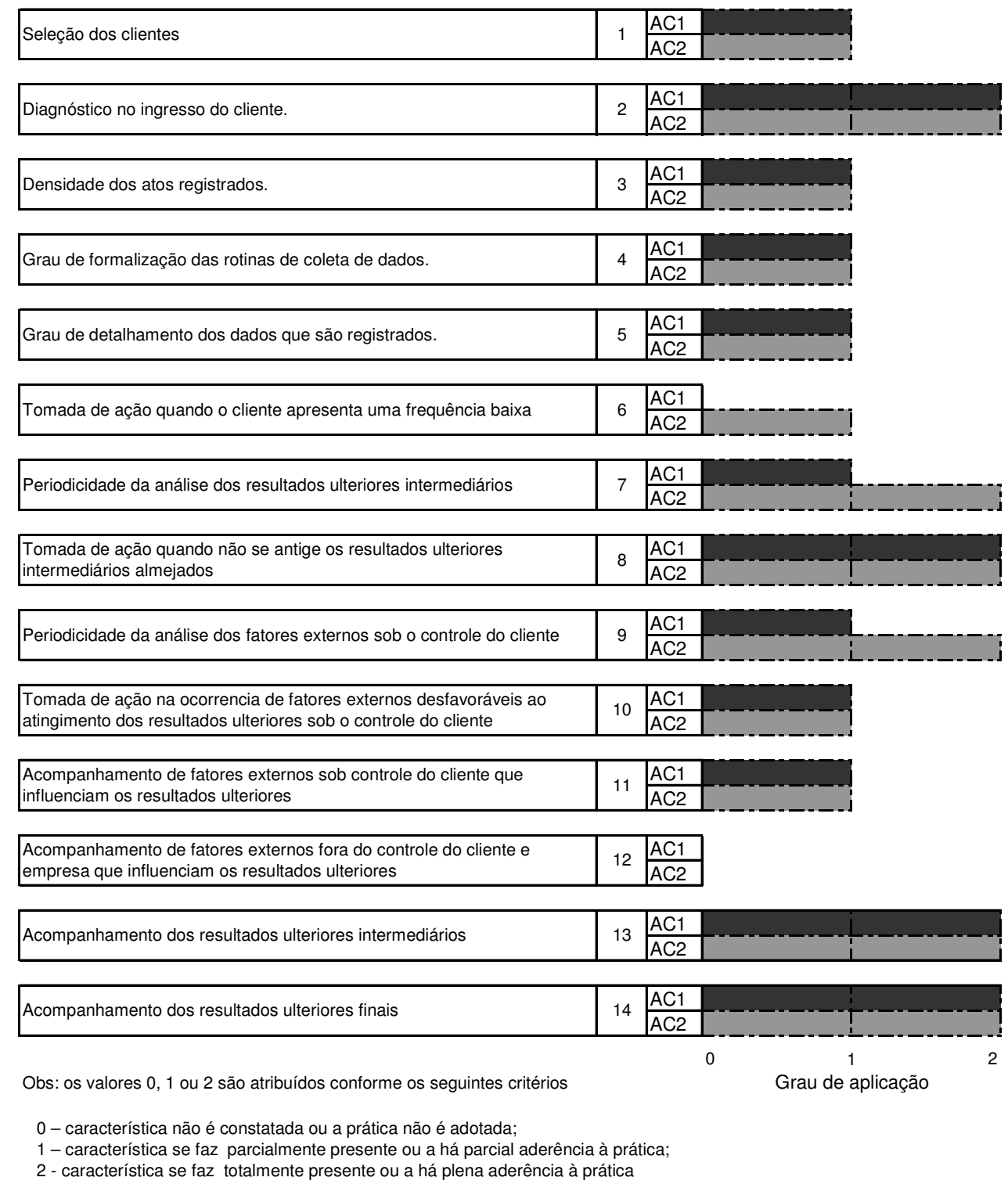

\section{GRÁFICO 6.1 - Sistema de monitoramento nos casos AC1 e AC2}

Fonte: Pesquisa do autor, 2007. 


\subsubsection{Uso de táticas que estimulam o envolvimento e a participação dos clientes}

Tanto o caso AC1 como o AC2 recorrem ao mesmo conjunto de táticas discutido na seção 3.5.2, apresentando portando um comportamento muito semelhante neste aspecto.

\section{TÁTICA}

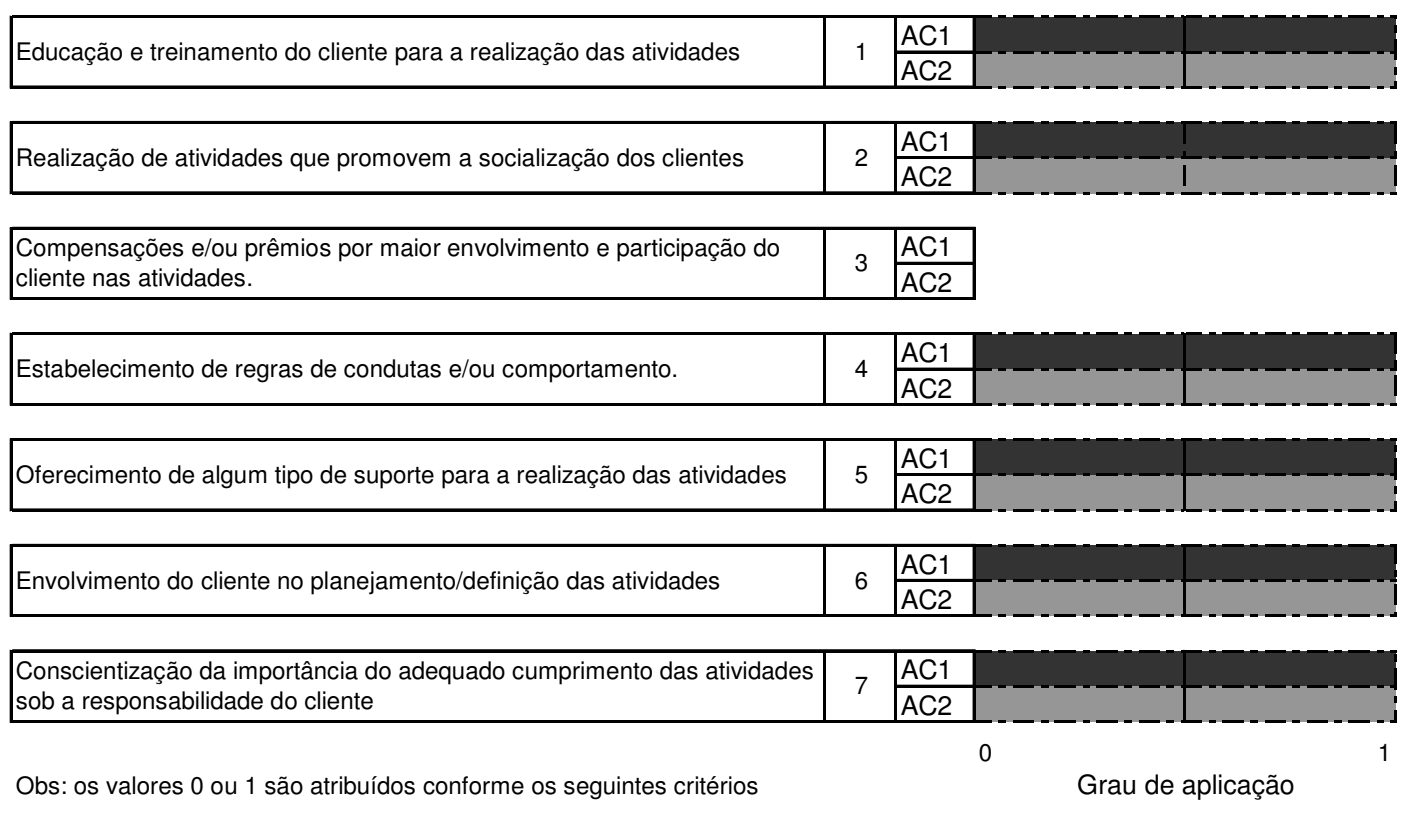

Valor 0 - tática ausente

Valor 1 - tática presente

GRÁFICO 6.2 - Uso de táticas que estimulam o envolvimento e a participação dos clientes nos casos AC1 e AC2

Fonte: Pesquisa do autor, 2007.

\subsubsection{Casos SS1 e SS2}

Ambos os casos se referem a cursos de preparação de pessoas para 0 mercado de trabalho e tanto no caso SS1 e SS2 são serviços de entidades sem fim 
lucrativo. Mas sob o ponto de vista da gestão de operações revelam algumas diferenças. Ao se analisar a variável grau de customização do serviço, verifica-se que o processo do caso SS2 apresenta um maior grau de customização que o do caso SS1. Além disso, o próprio conjunto de serviços ofertado por cada entidade é bastante diferente. O caso SS2 tem uma amplitude de serviços bem maior que o caso SS1. Como reflexo dessa maior amplitude de serviços e da maior necessidade de customização, o ciclo de aprendizado de um jovem no caso SS2 demanda um tempo total de 24 meses, ao passo que o ciclo de aprendizado do jovem no caso SS1 dura em torno de 3 a 4 meses. Soma-se a isso, a diferença existente em relação ao público atendido pelas duas entidades: o caso SS2 trabalha com jovens portadores de necessidades especiais o que exige da entidade um esforço e estrutura maior em seu processo produtivo.

\subsubsection{Sistema de monitoramento nas duas empresas}

O Gráfico 6.3 ilustra que os dois sistemas de monitoramento divergem bastante entre si. Enquanto no caso SS1 o grau de aplicação do sistema de monitoramento preconizado tenha se limitado a 36\%, no caso SS2 foi constatado um grau de $89 \%$, indicando maior aderência às várias das características e práticas

preconizadas pelo sistema de monitoramento do framework teórico exposto na seção 3.5.1. Trata-se de um resultado coerente com a natureza dos tipos de SRU desenvolvidos por SS1 e SS2. Sendo o serviço deste mais variado, complexo e longo, a adequada condução de seu processo de serviço depende do investimento de maior esforço e atenção num sistema de monitoramento. 


\section{CARACTERÍSTICAS PRÁTICAS}

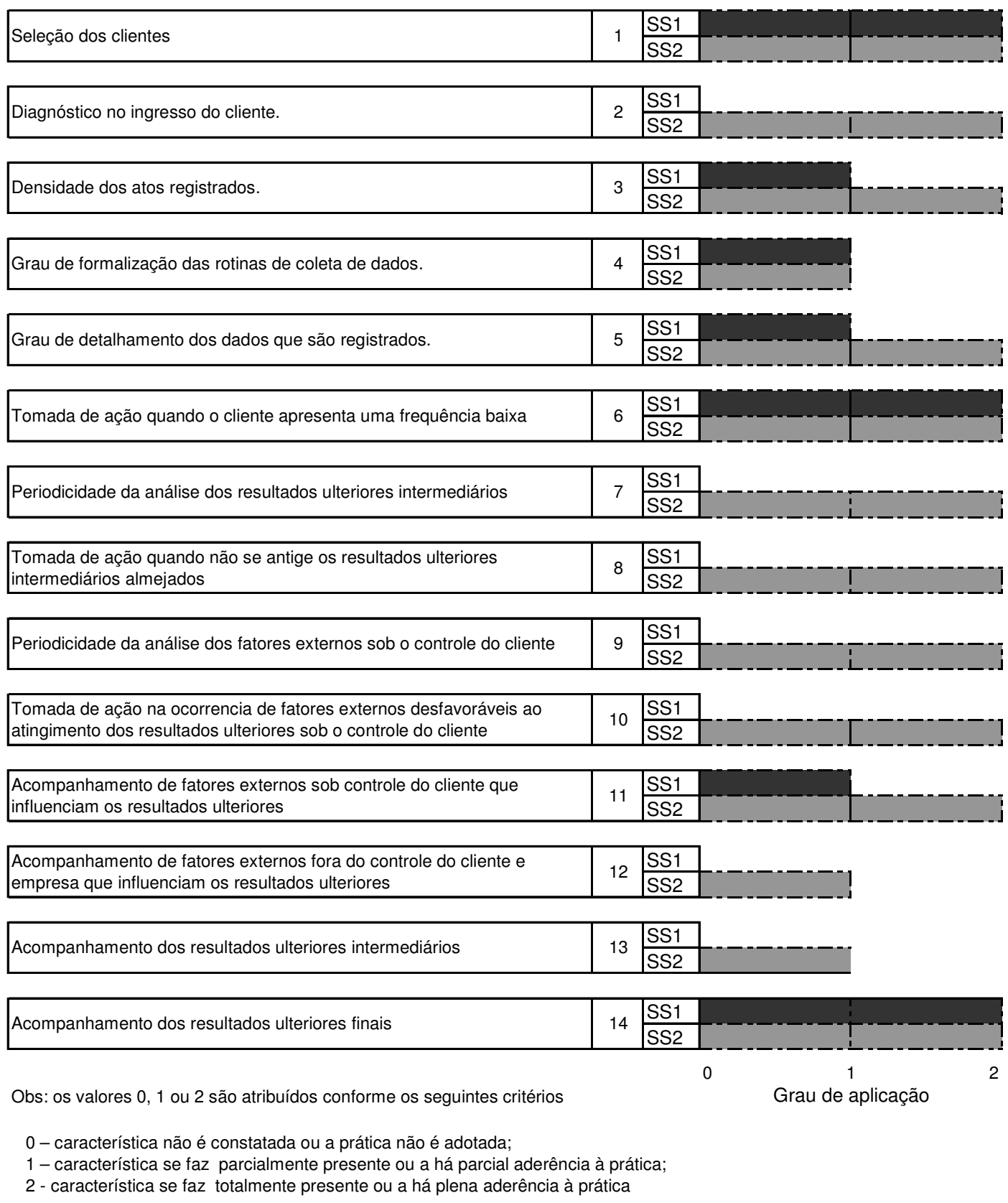

\section{GRÁFICO 6.3 - Sistema de monitoramento nos casos SS1 e SS2}

Fonte: Pesquisa do autor, 2007. 


\subsubsection{Uso de táticas que estimulam o envolvimento e a participação dos clientes}

Como se pode observar pelo Gráfico 6.4, tanto o caso SS1 como SS2 recorrem ao mesmo conjunto de táticas, com exceção da 5 , apresentando portando um padrão de gestão do processo de serviço muito semelhante neste aspecto.

\section{TÁTICA}

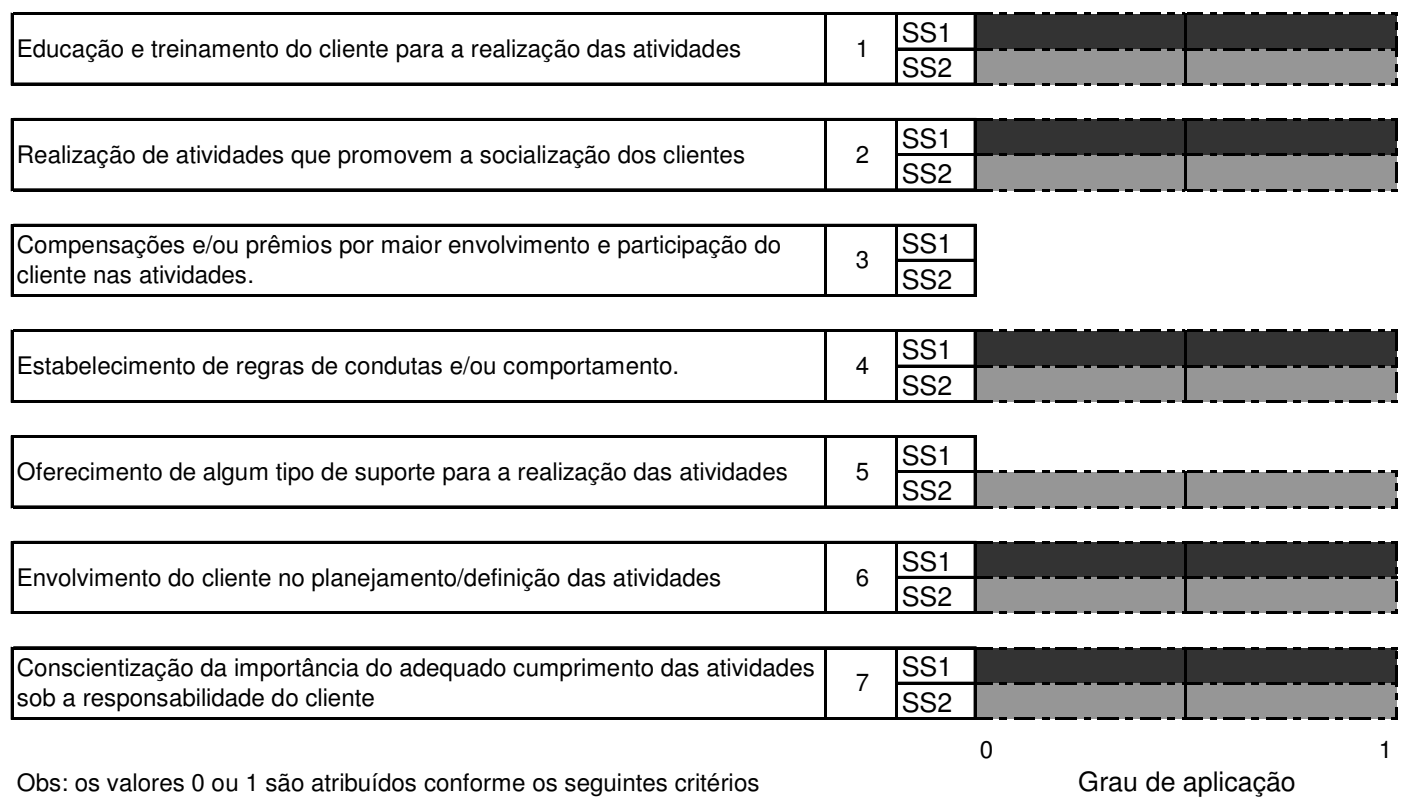

Valor 0 - tática ausente

Valor 1 - tática presente

GRÁFICO 6.4 - Uso de táticas que estimulam o envolvimento e a participação dos clientes nos casos SS1 e SS2. 


\subsubsection{Casos CP1 e CP2}

Estes dois casos se referem a serviços de cursinhos preparatórios para concursos.

\subsubsection{Sistema de monitoramento nas duas empresas}

Apesar de várias similaridades entre os dois serviços, existem diferenças significativas no grau de aplicação das características e práticas referentes ao sistema de monitoramento preconizado no framework teórico exposto na seção 3.5.1. Neste sentido, observa-se um maior cuidado na realização de atividades de correção e ajuste do processo de serviço por parte do caso CP1 nos itens 6, 7, 8, 9 e 10 avaliados. O baixo grau de aplicação do sistema de monitoramento e controle por parte do caso CP2 (33\%) está relacionado ao nível no qual as análises são realizadas pelo sistema. No caso CP2, o monitoramento do sistema não contempla o nível individual de análise, pois elas são realizadas considerando o desempenho global da turma e as análises individuais ficam sob a responsabilidade do aluno que as realiza por meio de exames simulados. 


\section{CARACTERÍSTICASI PRÁTICAS}

\begin{tabular}{|l|c|c|}
\hline Seleção dos clientes & 1 & CP1 \\
\\
\hline Diagnóstico no ingresso do cliente. & 2 & CP1 \\
\hline
\end{tabular}

\begin{tabular}{|c|c|c|}
\hline \multirow{2}{*}{ Densidade dos atos registrados. } & \multirow{2}{*}{3} & CP1 \\
\hline & & CP2 \\
\hline
\end{tabular}

\begin{tabular}{|c|c|c|}
\hline \multirow{2}{*}{ Grau de formalização das rotinas de coleta de dados. } & \multirow{2}{*}{4} & CP1 \\
\hline & & $\mathrm{CP} 2$ \\
\hline \multirow{2}{*}{ Grau de detalhamento dos dados que são registrados. } & \multirow{2}{*}{5} & CP1 \\
\hline & & $\mathrm{CP} 2$ \\
\hline
\end{tabular}

\begin{tabular}{|l|l|l|l|l|}
\hline Tomada de ação quando o cliente apresenta uma frequência baixa & 6 & CP1 & \\
\cline { 2 - 4 } & CP2 \\
\hline
\end{tabular}

\begin{tabular}{|l|l|l|l|l|}
\hline Periodicidade da análise dos resultados ulteriores intermediários & 7 & CP1 & \\
\cline { 2 - 4 } & & CP2 & \\
\hline
\end{tabular}

\begin{tabular}{|l|l|l|l|l|}
\hline $\begin{array}{l}\text { Tomada de ação quando não se antige os resultados ulteriores } \\
\text { intermediários almejados }\end{array}$ & 8 & CP1 & \\
\cline { 2 - 4 } & & CP2 \\
\hline
\end{tabular}

\begin{tabular}{|l|l|l|}
\hline Periodicidade da análise dos fatores externos sob o controle do cliente & 9 & CP1 \\
\cline { 2 - 4 } & CP2 \\
\hline
\end{tabular}

\begin{tabular}{|l|l|l|l|}
\hline $\begin{array}{l}\text { Tomada de ação na ocorrencia de fatores externos desfavoráveis ao } \\
\text { atingimento dos resultados ulteriores sob o controle do cliente }\end{array}$ & 10 & CP1 \\
\cline { 2 - 4 } & CP2 \\
\hline \begin{tabular}{|l|l|l|}
\hline $\begin{array}{l}\text { Acompanhamento de fatores externos sob controle do cliente que } \\
\text { influenciam os resultados ulteriores }\end{array}$ & 11 & CP1 \\
\cline { 2 - 4 }
\end{tabular} \\
\hline
\end{tabular}

\begin{tabular}{|l|l|l|}
\hline $\begin{array}{l}\text { Acompanhamento de fatores externos fora do controle do cliente e } \\
\text { empresa que influenciam os resultados ulteriores }\end{array}$ & \multirow{2}{*}{12} & $\mathrm{CP} 1$ \\
\cline { 3 - 3 } & & $\mathrm{CP} 2$ \\
\hline
\end{tabular}

\begin{tabular}{|l|l|l|l|l|}
\hline Acompanhamento dos resultados ulteriores intermediários & \multirow{2}{*}{13} & $\mathrm{CP} 1$ \\
\cline { 4 - 5 } & & $\mathrm{CP} 2$ & & \\
\hline
\end{tabular}

\begin{tabular}{l|l|l|l|}
\hline Acompanhamento dos resultados ulteriores finais & \multirow{2}{*}{14} & $\mathrm{CP} 1$ & \\
\cline { 2 - 3 } & $\mathrm{CP} 2$ & 0 & 1 \\
Obs: os valores 0,1 ou 2 são atribuídos conforme os seguintes critérios & Grau de aplicação
\end{tabular}

\footnotetext{
0 - característica não é constatada ou a prática não é adotada;

1 - característica se faz parcialmente presente ou a há parcial aderência à prática;

2 - característica se faz totalmente presente ou a há plena aderência à prática
}

\section{GRÁFICO 6.5 - Sistema de monitoramento nos casos CP1 e CP2}

Fonte: Pesquisa do autor, 2007. 


\subsubsection{Uso de táticas que estimulam o envolvimento e a participação dos clientes}

De um modo geral, os dois casos recorrem ao mesmo conjunto de táticas, com exceção da 2 adotada apenas por CP2. Assim, revelam um comportamento muito semelhante neste aspecto.

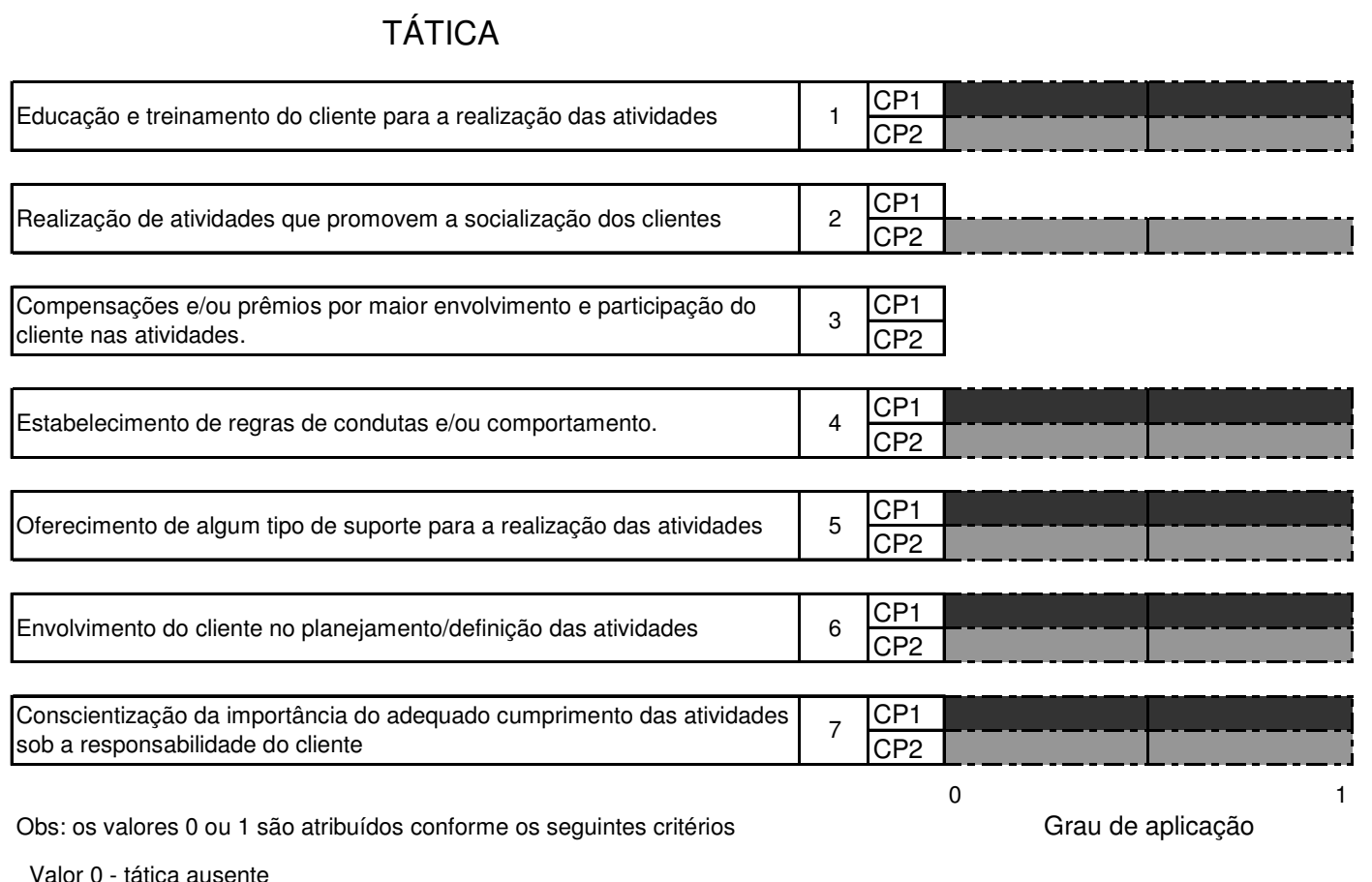

Valor 1 - tática presente

GRÁFICO 6.6 - Uso de táticas que estimulam o envolvimento e a participação dos clientes nos casos CP1 e CP2

Fonte: Pesquisa do autor, 2007. 


\subsection{ANÁLISE ENTRE OS PARES DE CASOS}

Não se observou uma sensível distinção nas características estudadas entre os pares de casos AC1 \& AC2 e CP1 \& CP2 e SS1 \& SS2 tanto em termos de adoção de um sistema de monitoramento como de uso de táticas que estimulem o envolvimento e a participação dos clientes. Verificou-se apenas que a prática de seleção de clientes é mais adotada no par de casos SS1 \& SS2 (entidades sem fins lucrativos) do que nos demais casos. A adoção desta prática em maior grau nestas entidades é compreensível, pois elas destinam suas atividades a um determinado público que apresenta características específicas. No caso SS1 o público atendido é formado por jovens carentes moradores da região próxima à entidade. No caso SS2 são jovens de 14 a 25 anos moradores da região próxima à entidade com necessidades especiais e que atendam aos requisitos avaliados na primeira etapa do processo de serviço desta entidade. O par de casos AC1 \& AC2 (academias de ginástica) realiza a seleção de clientes como um meio de prevenir que pessoas portadoras de problemas de saúde que estejam inaptas a realizarem atividades físicas venham a ser indevidamente admitidas. O critério de corte no par de casos AC1 \& AC2 é bem menos restritivo que o utilizado pelo par de casos SS1 \& SS2. O Gráfico 6.7 ilustra o grau de adoção da prática de seleção dos clientes nos casos estudados 


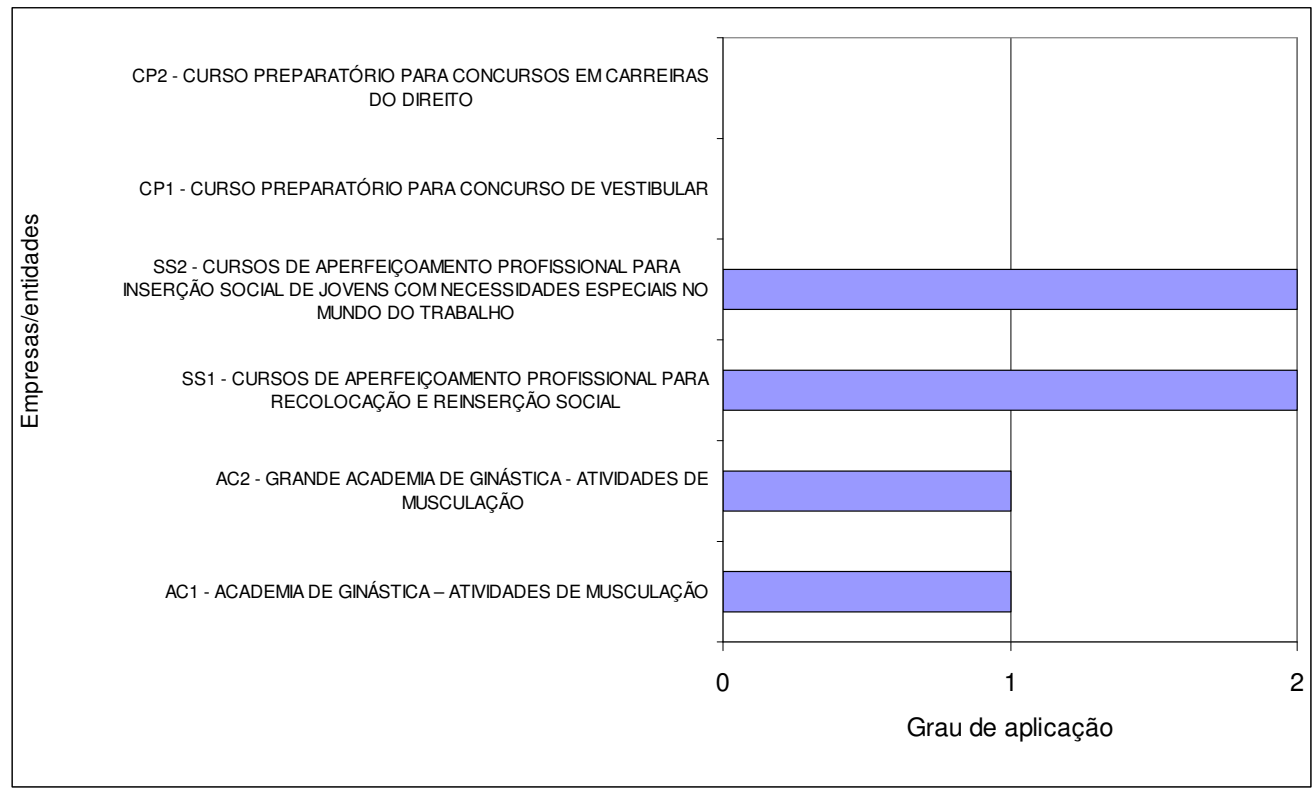

GRÁFICO 6.7 - Grau de adoção da prática de seleção dos clientes nos casos estudados

Fonte: Pesquisa do autor, 2007.

Obs: os valores 0,1 ou 2 são atribuídos conforme os seguintes critérios

0 - característica não é constatada ou a prática não é adotada;

1 - característica se faz parcialmente presente ou a há parcial aderência à prática;

2 - característica se faz totalmente presente ou a há plena aderência à prática

\subsection{ANÁLISE ENTRE ENTIDADES SEM FINS LUCRATIVOS E EMPRESAS QUE VISAM AO LUCRO}

As organizações pesquisadas podem ser divididas em entidades sem fins lucrativos (SS1 e SS2) e empresas que visam ao lucro (AC1, AC2, CP1 e CP2). De forma semelhante ao que ocorreu na seção 6.2 , não se observou uma sensível distinção entre os dois tipos de organização em termos das características estudadas, tanto no que tange ao sistema de monitoramento como ao uso de táticas que estimulam o envolvimento e a participação dos clientes. Um ponto em que estes dois tipos de organização diferem é a necessidade de captar clientes por meio de 
publicidade e/ou por meio de atividades de promoção como a concessão de descontos na matrícula/mensalidade nas empresas que visam ao lucro. Esta característica foi verificada em 3 das 4 empresas deste tipo. No caso AC2, por ser uma academia de musculação de um grande clube, não foi verificada a necessidade de realizar tais atividades. Já as entidades sem fins lucrativos estudadas enfrentam uma demanda maior que sua capacidade de atendimento portanto, em vez de captar novos clientes, necessitam filtrar sua demanda.

\subsection{ANÁLISE CONJUNTA DOS CASOS}

Antes da análise conjunta dos seis casos, faz-se necessário apresentar algumas considerações sobre o modo como os desempenhos foram calculados nas diferentes empresas. Essas ponderações possibilitam um ajuizamento acerca do grau de precisão dos valores obtidos em cada caso. Elas estão expostas no Quadro 6.1 , mostrado a seguir.

\begin{tabular}{|c|c|}
\hline Empresa/entidade analisada & Forma de estimação \\
\hline $\begin{array}{l}\text { Caso AC1 - Academia de ginástica - atividades de } \\
\text { musculação }\end{array}$ & $\begin{array}{l}\text { Amostragem pouco representativa. Tamanho da Amostra: } 67 \text { pessoas para a estimação } \\
\text { da taxa de retenção e } 10 \text { pessoas para estimação da eficácia. Freqüência por meio de } \\
\text { amostragem. }\end{array}$ \\
\hline $\begin{array}{l}\text { Caso AC2 - Grande academia de ginástica - } \\
\text { atividades de musculação }\end{array}$ & $\begin{array}{l}\text { Considerou-se uma turma de } 720 \text { pessoas para estimação da taxa de retenção e } \\
\text { considerou-se uma turma de } 100 \text { pessoas para estimação da eficácia. Freqüência } \\
\text { estimada baseando-se na quantidade de clientes presentes em um dado intervalo de } \\
\text { tempo. }\end{array}$ \\
\hline $\begin{array}{l}\text { Caso SS1 - Cursos de aperfeiçoamento profissional } \\
\text { para recolocação e re-inserção social }\end{array}$ & $\begin{array}{l}\text { Eficácia e taxa de retenção através de todas as turmas de alunos assistidas em } 2005 . \\
\text { Freqüência por meio de amostragem, considerando apenas os alunos que concluíram o } \\
\text { curso. }\end{array}$ \\
\hline $\begin{array}{l}\text { Caso SS2 - Cursos de aperfeiçoamento profissional } \\
\text { para inserção social de jovens com necessidades } \\
\text { especiais no mundo do trabalho }\end{array}$ & $\begin{array}{l}\text { Eficácia e Taxa de Retenção através de todas as turmas de alunos assistidas } 2005 . \\
\text { Freqüência por meio de amostragem }\end{array}$ \\
\hline $\begin{array}{l}\text { Caso CP1 - Curso preparatório para concurso de } \\
\text { vestibular }\end{array}$ & $\begin{array}{l}\text { Eficácia e taxa de retenção através de todas as turmas de alunos que realizaram } \\
\text { concurso de vestibular em 2004. Freqüência por meio de amostragem. }\end{array}$ \\
\hline $\begin{array}{l}\text { Caso CP2 - Curso preparatório para concursos } \\
\text { públicos na área de direito }\end{array}$ & $\begin{array}{l}\text { Amostragem pouco representativa. A freqüência, taxa de retenção e eficácia foram } \\
\text { calculadas considerando algumas valores médios de alguns cursos realizados. }\end{array}$ \\
\hline
\end{tabular}

QUADRO 6.1 - Tipo de estimação para o cálculo do desempenho nas diferentes empresas pesquisadas

Fonte: Pesquisa do autor, 2007. 
Analisando-se, para cada caso pesquisado, a forma de estimação considerada, constata-se que os casos AC1 e CP2 não fornecem valores precisos para se efetuar uma comparação conjunta de todos casos estudados, em relação aos três indicadores de desempenho. Assim, dadas as dificuldades e limitações enfrentadas durante a pesquisa de campo para identificação e coleta de dados comparáveis em todos os casos, neste estudo optou-se por não levar em consideração os dados dos casos AC1 e CP2 para a verificação das proposições levantadas no trabalho e para a análise conjunta de dados.

\subsubsection{Sistema de monitoramento e controle nas empresas/entidades}

Em todos os casos analisados foi identificada a existência de um sistema de monitoramento e controle (pessoas, instalações, equipamentos e procedimentos direcionados para esta atividade) voltado para o relacionamento com o cliente. Portanto, os gestores das empresas e entidades pesquisadas buscam por meio desse sistema entender o comportamento do seu público e as atividades realizadas para ele e com ele, no decorrer de um longo ciclo de transações, dentro da perspectiva de criar um relacionamento prolongado entre a empresa e o cliente.

Identificou-se que todos os sistemas de monitoramento analisados registram a freqüência da clientela às atividades. Todos os sistemas, também, contemplaram em algum(ns) episódio(s) específico(s) o registro de dados referentes a alguns dos seus atos.

A Tabela 6.1 reporta o grau de aplicação das características e práticas do sistema de monitoramento considerado pelo Framework teórico exposto na seção 3.5.1 nas empresas/entidades pesquisadas. 


\section{TABELA 6.1 - Grau de aplicação do sistema de monitoramento nas empresas/entidades pesquisadas}

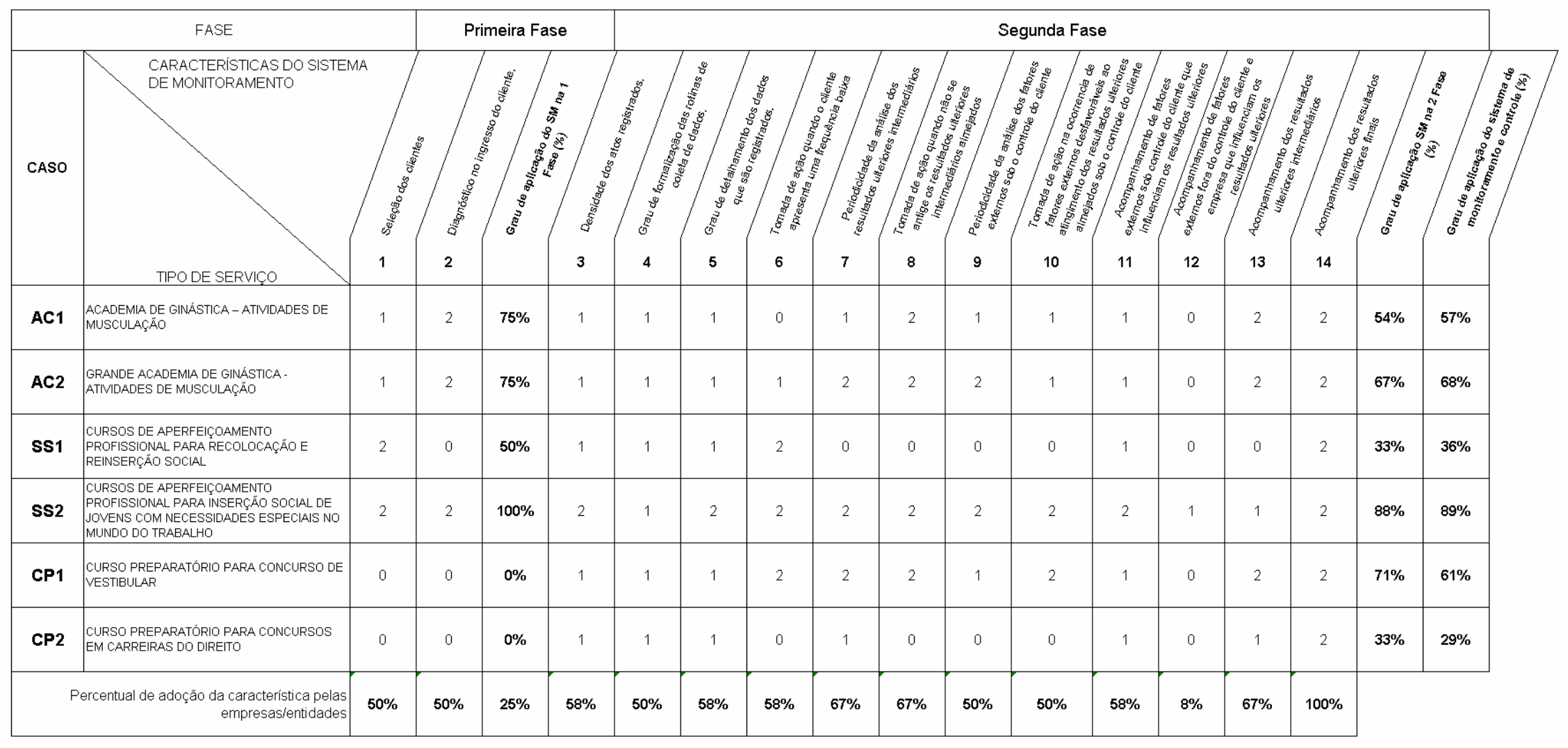

Obs: os valores 0,1 ou 2 săo atribuidos conforme os seguintes critérios

0 - característica năo é constatada ou a prática năo é adotada;

1 - caracteristica se faz parcialmente presente ou a ha parcial aderência à prática.

2 - característica se faz totalmente presente ou a há plena aderência à prática 


\subsubsection{Influência dos fatores externos sobre a eficácia do serviço}

Antes de discutir como os diferentes serviços analisados são monitorados, vale entender, mesmo que de um modo genérico, os fatores externos que afetam a sua eficácia. Com base nos dados levantados na pesquisa de campo, os principais fatores que têm afetado a eficácia dos SRUs investigados nos diferentes estudos de caso são relacionados na Tabela 6.2.

TABELA 6.2 -Fatores externos que impactam a eficácia nas diferentes empresas

\begin{tabular}{|c|c|c|c|}
\hline Estudo de caso & $\begin{array}{l}\text { Principais fatores externos } \\
\text { sob controle do cliente }\end{array}$ & $\begin{array}{l}\text { Principais fatores externos } \\
\text { exógenos }\end{array}$ & Eficácia \\
\hline $\begin{array}{l}\text { AC2 - Grande academia de } \\
\text { ginástica - atividades de } \\
\text { musculação }\end{array}$ & $\begin{array}{ll}- & \text { Freqüência } \\
\text { - } & \text { Respeito à ficha de } \\
& \text { treinamento } \\
\text { - } & \text { Respeito ao tempo de } \\
& \text { intervalo entre as séries } \\
& \text { de exercícios } \\
\text { - } & \text { Dieta alimentar adequada }\end{array}$ & & $55 \%$ \\
\hline $\begin{array}{l}\text { CP1 - Curso preparatório } \\
\text { para concurso de vestibular }\end{array}$ & $\begin{array}{ll} & \text { Freqüência } \\
\text { - } & \text { Participação e interesse } \\
\text { - } & \text { Tempo de estudo }\end{array}$ & $\begin{array}{l}\text { - Grau de concorrência do } \\
\text { curso no vestibular }\end{array}$ & $51 \%$ \\
\hline $\begin{array}{l}\text { SS1 - Cursos de } \\
\text { aperfeiçoamento profissional } \\
\text { para recolocação e reinserção } \\
\text { social }\end{array}$ & $\begin{array}{ll}\text { - } & \text { Freqüência } \\
\text { - } & \text { Participação e interesse }\end{array}$ & $\begin{array}{l}\text { - Oferta de empregos na } \\
\text { região }\end{array}$ & $46 \%$ \\
\hline $\begin{array}{l}\text { SS2 - Cursos de } \\
\text { aperfeiçoamento profissional } \\
\text { para inserção social de jovens } \\
\text { com necessidades especiais } \\
\text { no mundo do trabalho }\end{array}$ & $\begin{array}{ll}\text { - } & \text { Freqüência } \\
\text { - } & \text { Participação e interesse }\end{array}$ & $\begin{array}{ll}- & \text { Oferta de empregos na } \\
& \text { região } \\
\text { - } & \text { Interesse da empresa em } \\
\text { incluir jovens com } \\
\text { necessidades especiais } \\
\text { em seu quadro* } \\
\text { - } & \text { Postura e apoio da família }\end{array}$ & $16 \%$ \\
\hline
\end{tabular}

* A entidade conta com a ajuda da legislação que obriga as companhias com mais de 100 funcionários contratarem uma porcentagem de trabalhadores portadores de deficiência.

Fonte: Pesquisa do autor, 2007.

Ainda que baseada numa avaliação apenas qualitativa, observa-se, pela Tabela 6.2, que quanto maior a influência de fatores externos sobre o serviço maior é o risco de não se obter resultados ulteriores almejados e, portanto, o nível de eficácia obtido pelas empresas/entidades tende a ser menor. 


\subsubsection{Primeira fase - Procedimentos de seleção e de diagnóstico}

O Quadro 6.4 relaciona as práticas de seleção e diagnóstico no ingresso de clientes adotadas pelas diferentes empresas/entidades investigadas nos estudos de casos.

\begin{tabular}{|l|l|l|}
\hline Estudo de caso & Rotina de seleção & Rotina de diagnóstico no ingresso \\
\hline $\begin{array}{l}\text { AC1 - Academia de ginástica - } \\
\text { atividades de musculação }\end{array}$ & $\begin{array}{l}\text { Existe. Inclusa nas primeiras } \\
\text { avaliações física e fisioterápica. }\end{array}$ & $\begin{array}{l}\text { Existe. Realizadas nas primeiras } \\
\text { avaliações física e fisioterápica que } \\
\text { definem a ficha de treinamento. }\end{array}$ \\
\hline $\begin{array}{l}\text { AC2 - Grande academia de } \\
\text { ginástica - atividades de } \\
\text { musculação }\end{array}$ & $\begin{array}{l}\text { Existe. São feitos dois exames: } \\
\text { cardiológico e funcional. A } \\
\text { entrevista e os exames definem se } \\
\text { o cliente está apto ou não. }\end{array}$ & $\begin{array}{l}\text { Existe. O primeiro exame funcional } \\
\text { e a entrevista definem a ficha de } \\
\text { treinamento. }\end{array}$ \\
\hline $\begin{array}{l}\text { SS1 - Cursos de aperfeiçoamento } \\
\text { profissional para recolocação e } \\
\text { reinserção social }\end{array}$ & Realiza seleção dos alunos. & Não realiza esta prática. \\
\hline $\begin{array}{l}\text { SS2 - Cursos de aperfeiçoamento } \\
\text { profissional para inserção social de } \\
\text { jovens com necessidades especiais } \\
\text { no mundo do trabalho }\end{array}$ & Existe. Há um extenso processo de & triagem para a seleção do jovem. \\
\hline $\begin{array}{l}\text { CP1 - Curso preparatório para } \\
\text { concurso de vestibular }\end{array}$ & Não realiza esta prática. & $\begin{array}{l}\text { Existe. Na primeira etapa, antes de ser selecionado, ele é } \\
\text { diadicado por uma equipe } \\
\text { multifuncional da empresa. }\end{array}$ \\
\hline $\begin{array}{l}\text { CP2 - Curso preparatório para } \\
\text { concursos em carreiras do direito }\end{array}$ & Não realiza esta prática. & Não realiza esta prática. \\
\hline
\end{tabular}

QUADRO 6.2 - Práticas de seleção e diagnóstico de clientes nas diferentes empresas/entidades

Fonte: Pesquisa do autor, 2007.

Observa-se que apenas os cursos preparatórios não realizam a seleção de seus clientes. Mas aos clientes que se matricularem, eles utilizam a concessão de bolsas de estudos como meio para tentar reter aqueles com bom aproveitamento nos exames simulados.

A prática de diagnóstico nem sempre é realizada. Entende-se que ela é fundamental quando existe a necessidade de personalização do serviço. Isso se fez presente nas academias de ginástica, onde a ficha de treinamento é individualizada, e no curso de aperfeiçoamento profissional de jovens com necessidades especiais, que necessitam de um apoio clínico, ou seja, de um serviço individualizado.

Segundo Surprenant e Solomon (1987), a personalização em serviços pode ocorrer de três modos: i) Personalização dos Produtos: o cliente escolhe um serviço dentre uma série de possibilidades existentes; ii) Personalização Programada: 
consiste em pequenos diálogos em que se trata o cliente de modo pessoal ou familiar; iii) Personalização Customizada: consiste em ajustar as atividades do processo às necessidades do cliente.

Ao se tomar como referência os tipos de personalização segundo Surprenant e Solomon (1987), entende-se que tanto as academias de ginástica como o curso de aperfeiçoamento profissional de jovens com necessidades especiais realizam a personalização customizada.

\subsubsection{Segunda fase - Análise dos dados e tomada de ações}

O Quadro 6.5 relaciona as diferentes práticas adotadas pelas empresas/entidades no que se refere à análise dos resultados ulteriores intermediários e freqüência dos clientes e tomada de ações que se fizerem necessárias. Nota-se que todas as empresas/entidades pesquisadas apresentam uma rotina de coleta e análise de dados orientada ao objetivo de SRU oferecido. 


\begin{tabular}{|c|c|c|c|}
\hline Estudo de Caso & Análise & Freqüência & Tomada de ações \\
\hline $\begin{array}{l}\text { AC1 - Academia de ginástica } \\
\text { - atividades de musculação }\end{array}$ & $\begin{array}{l}\text { - Por meio da reavaliação } \\
\text { física e fisioterápica e } \\
\text { da análise da freqüência } \\
\text { do cliente nas } \\
\text { atividades }\end{array}$ & $\begin{array}{l}\text { - } \quad \text { Trimestral. Mas poucos } \\
\text { clientes fazem esta } \\
\text { reavaliação. (O preço é } \\
\text { o principal motivo } \\
\text { alegado para não fazê- } \\
\text { la). }\end{array}$ & $\begin{array}{l}\text { - Ações de orientação } \\
\text { sobre o serviço } \\
\text { (Exemplos: orientações } \\
\text { sobre dieta e a } \\
\text { importância da } \\
\text { regularidade da prática } \\
\text { de exercícios). } \\
\text { Modificação da Ficha } \\
\text { de Treinamento } \\
\end{array}$ \\
\hline $\begin{array}{l}\text { AC2 - Grande academia de } \\
\text { ginástica - atividades de } \\
\text { musculação }\end{array}$ & $\begin{array}{l}\text { - A cada reavaliação é } \\
\text { feito um exame } \\
\text { funcional. } \\
\text { - A freqüência é } \\
\text { monitorada pelos } \\
\text { atendentes. }\end{array}$ & $\begin{array}{l}\text { - A freqüência } \\
\text { predominante do exame } \\
\text { funcional é trimestral. A } \\
\text { empresa obriga a } \\
\text { realização de um exame } \\
\text { anual cardiológico e } \\
\text { funcional. }\end{array}$ & $\begin{array}{ll}- & \text { Ações de orientação } \\
\text { sobre o serviço. } \\
\text { - } \quad \text { Modificação da Ficha de } \\
\text { Treinamento. } \\
\text { - Os alunos com } \\
\text { freqüência baixa são } \\
\text { contatados e } \\
\text { orientados. }\end{array}$ \\
\hline $\begin{array}{l}\text { SS1 - Cursos de } \\
\text { aperfeiçoamento profissional } \\
\text { para recolocação e } \\
\text { reinserção social }\end{array}$ & $\begin{array}{l}\text { - Acompanhamento } \\
\text { realizado pelo instrutor } \\
\text { em sala de aula por } \\
\text { Diário de Classe. }\end{array}$ & $\begin{array}{l}\text { - Em cada aula } \\
\text { ministrada. }\end{array}$ & $\begin{array}{ll}\text { - } & \text { Os alunos com } \\
\text { freqüência baixa são } & \\
\text { contatados e } & \\
\text { orientados. } \\
\text { - } \quad \begin{array}{l}\text { Ações de orientação } \\
\text { podem ser tomadas }\end{array} \\
\end{array}$ \\
\hline $\begin{array}{l}\text { SS2 - Cursos de } \\
\text { aperfeiçoamento profissional } \\
\text { para inserção social de } \\
\text { jovens com necessidades } \\
\text { especiais no mundo do } \\
\text { trabalho }\end{array}$ & $\begin{array}{l}\text { - Existem várias rotinas } \\
\text { de avaliação. }\end{array}$ & $\begin{array}{l}\text { - Diária, semanal, } \\
\text { trimestral, semestral e } \\
\text { anual. }\end{array}$ & $\begin{array}{ll}\text { - } & \text { Redirecionamento das } \\
\text { atividades. } \\
\text { - } \quad \text { Orientação ao jovem ou } \\
\text { à sua família. } \\
\text { - Encaminhamento para } \\
\text { atendimento clínico }\end{array}$ \\
\hline $\begin{array}{l}\text { CP1 - Curso preparatório } \\
\text { para concurso de vestibular }\end{array}$ & $\begin{array}{l}\text { - A freqüência e as notas } \\
\text { dos alunos nos exames } \\
\text { simulados são } \\
\text { monitoradas. }\end{array}$ & $\begin{array}{ll}- & \text { Freqüência é mensal. } \\
- & \text { Notas monitoradas a } \\
& \text { cada exame. São } \\
& \text { realizados } 2 \text { exames } \\
& \text { simulados por semestre. }\end{array}$ & $\begin{array}{ll}\text { - } & \text { Ações de orientação } \\
& \text { podem ser tomadas }\end{array}$ \\
\hline & $\begin{array}{l}\text { - As análises realizadas } \\
\text { pela empresa são } \\
\text { globais. }\end{array}$ & & $\begin{array}{l}\text { - A empresa poderá } \\
\text { alterar o curso. }\end{array}$ \\
\hline $\begin{array}{l}\text { CP2 - Curso preparatório } \\
\text { para concursos em carreiras } \\
\text { do direito }\end{array}$ & $\begin{array}{l}\text { - A análise individual fica } \\
\text { sob a responsabilidade } \\
\text { do aluno, por meio de } \\
\text { exames simulados. }\end{array}$ & & $\begin{array}{l}\text { O aluno poderá dedicar } \\
\text { mais o tempo de } \\
\text { estudo, procurar } \\
\text { monitoria. Buscar } \\
\text { esclarecimento de } \\
\text { dúvidas e/ou orientação } \\
\text { com o professor. }\end{array}$ \\
\hline
\end{tabular}

QUADRO 6.3 - Rotinas de coleta e análise dos dados nas diferentes empresaslentidades

Fonte: Pesquisa do autor, 2007. 


\subsubsection{Táticas que estimulam o envolvimento e a participação dos clientes}

A adoção de táticas que estimulam o envolvimento e a participação dos clientes nas empresas/entidades pesquisad é apresentada na Tabela 6.3.

QUADRO 6.4 - Adoção de táticas que estimulam o envolvimento e a participação dos clientes pelas diferentes empresas

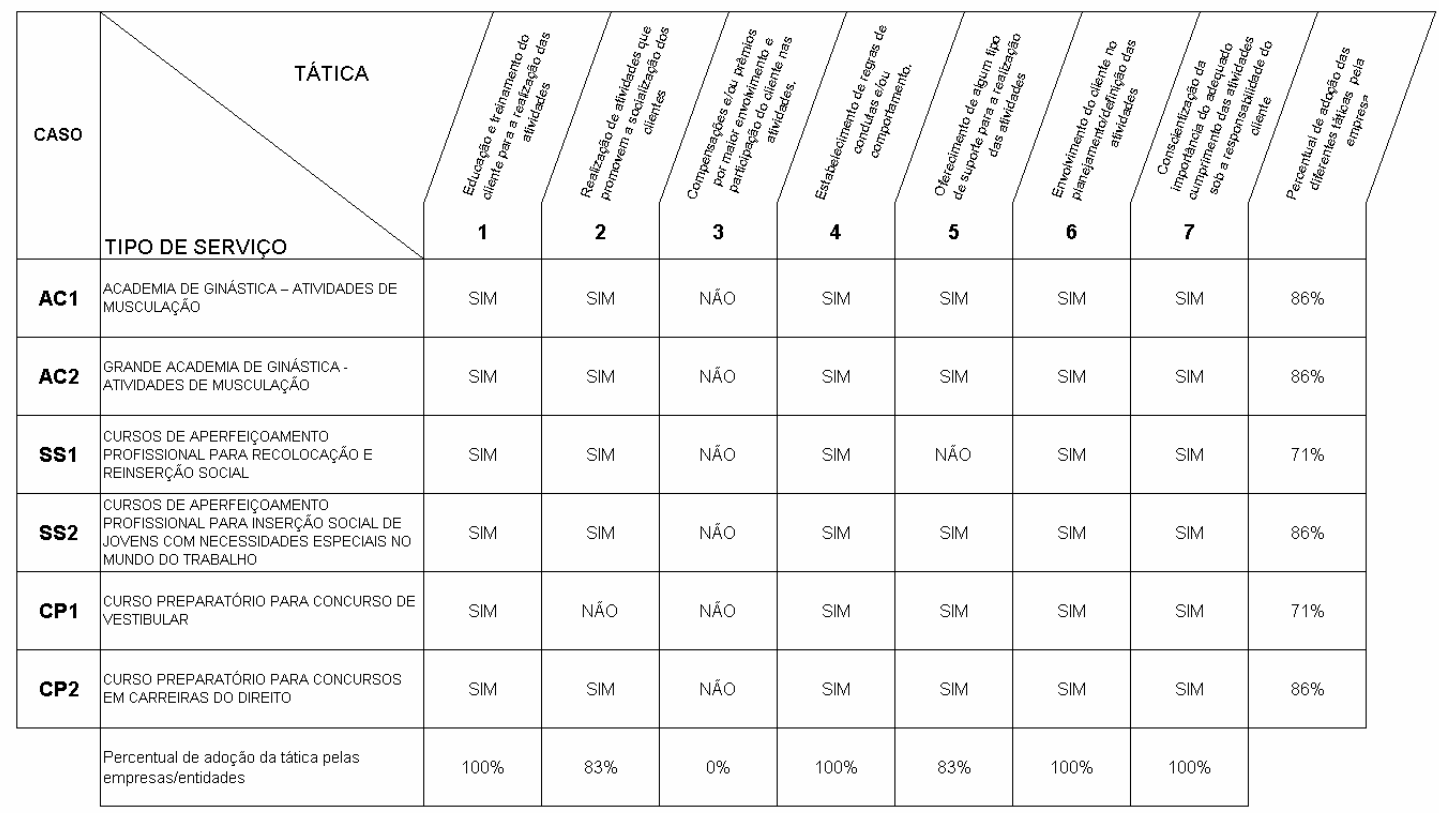

Fonte: Pesquisa do autor, 2007.

Uma análise comparativa das táticas que estimulam o envolvimento e a participação dos clientes revela que a maioria dessas táticas são adotadas nas empresas/entidades investigadas sendo que 4 das 7 táticas $(1,4,6$ e 7$)$ são utilizadas por $100 \%$ das empresas/entidades e 2 táticas (2 e 5) por $83 \%$ delas.

Nenhuma empresa/entidade dá prêmios ou compensações por maior envolvimento e participação do cliente nas atividades. Neste aspecto, uma possível inferência para explicar a não-utilização dessa tática é considerar que as empresas/entidades entendem como uma obrigação os clientes se envolverem e participarem do serviço quando a sua natureza é a de um SRU. 


\subsubsection{Resultados de desempenho obtidos}

\subsubsection{Resultados referentes à eficácia}

Os valores alcançados pelas empresas/entidades pesquisadas para este indicador variaram bastante. O Gráfico 6.8 mostra os valores obtidos em cada caso, do maior ao menor valor.

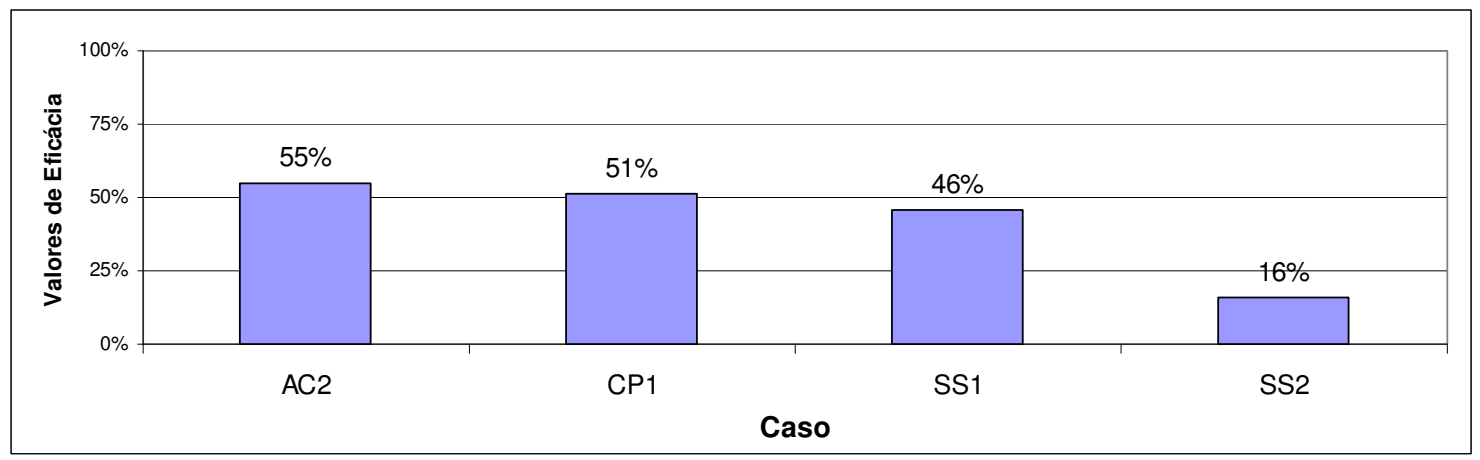

GRÁFICO 6.8 - Resultados de eficácia nas diferentes empresas/entidades analisadas.

Fonte: Pesquisa do autor, 2007.

Pelo Gráfico 6.8 observa-se que o caso SS2 apresenta um valor de eficácia muito inferior que os demais.

Um aspecto já ressaltado e discutido na revisão da literatura (seção 3.3.4.1) que justificaria valores mais baixos nas empresas/entidades analisadas é a predominância de fatores externos como os expostos no Tabela 6.2. 


\subsubsection{Resultados referentes à retenção}

As empresas/entidades pesquisadas apresentaram valores que oscilam entre 96\% e 75\% para este indicador. O Gráfico 6.9 mostra os valores da taxa de retenção obtidos em cada caso, do maior ao menor valor.

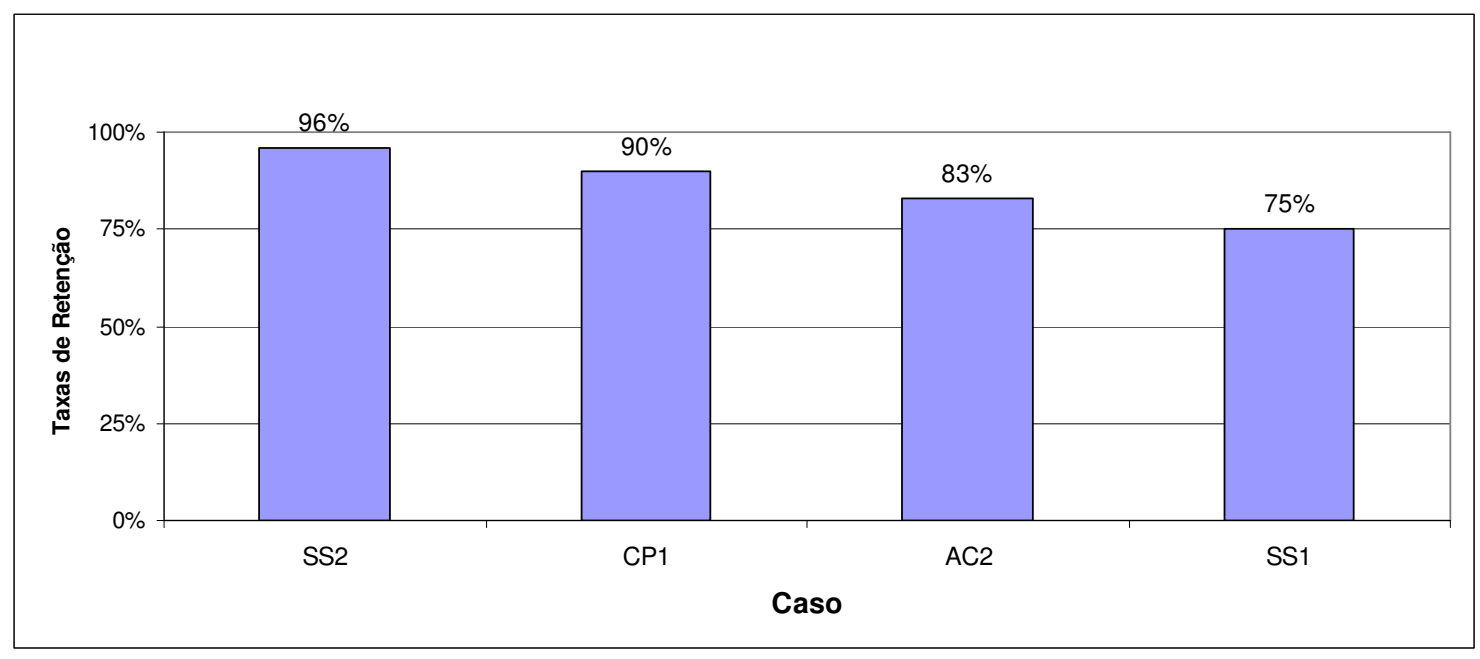

GRÁFICO 6.9 - Resultados para taxa de retenção nas diferentes empresas/entidades analisadas.

Fonte: Pesquisa do autor, 2007.

Pelo Gráfico 6.9 não se observa uma dispersão tão grande de dados como a que foi verificada para a eficácia no Gráfico 6.8.

O caso AC2 refere-se a uma academia de ginástica pertencente a um clube. Os clientes, sendo sócios do clube, podem usufruir os vários serviços oferecidos pelo mesmo, tais como: bar, sauna, restaurante, estacionamento, salão de beleza, piscina e vários tipos de esportes. Além disso, o preço da mensalidade da AC2 chega a ser menos da metade do que normalmente é cobrado por outras academias de mesmo porte. Outro aspecto constatado durante a pesquisa de campo é a existência de uma ampla rede de relacionamentos entre os usuários da academia, na maioria das vezes, já desenvolvida anteriormente em outras atividades fornecidas pelo clube ou reforçadas pelas mesmas. Ao se adotar a perspectiva sobre relacionamento entre empresa e cliente proposta por Berry e Parasuraman (1995), 
verifica-se que, o relacionamento existente entre no caso AC2 e seus clientes se situa no nível três. Nesse nível, a empresa consolida os relacionamentos com elos estruturais, além dos elos sociais e financeiros. A retenção do cliente torna-se mais segura, o que explica sua alta taxa de retenção em comparação com taxas mais baixas que predominam no setor de academias de ginástica.

De modo semelhante ao caso AC2, o caso SS2 refere-se a uma entidade que também desenvolve um vínculo maior com seus clientes por meio de elos estruturais. Ela oferece vários outros serviços que objetivam a inclusão de jovens com necessidades especiais na escola e na sociedade. Soma-se a isso, o fato dessa entidade trabalhar inclusive com a família do jovem, além de, em alguns casos iniciar as atividades quando o cliente é ainda bebê.

Os casos AC2 e SS2, portanto, corroboram as idéias discutidas na literatura de marketing de serviços pelos autores Berry e Parasuraman (1995),.

\subsubsection{Resultados referentes à freqüência}

Os valores de freqüência oscilam entre 95\% e 54\% nas empresas/entidades pesquisadas. O Gráfico 6.10 mostra os valores de freqüência em cada caso, do maior ao menor valor. 


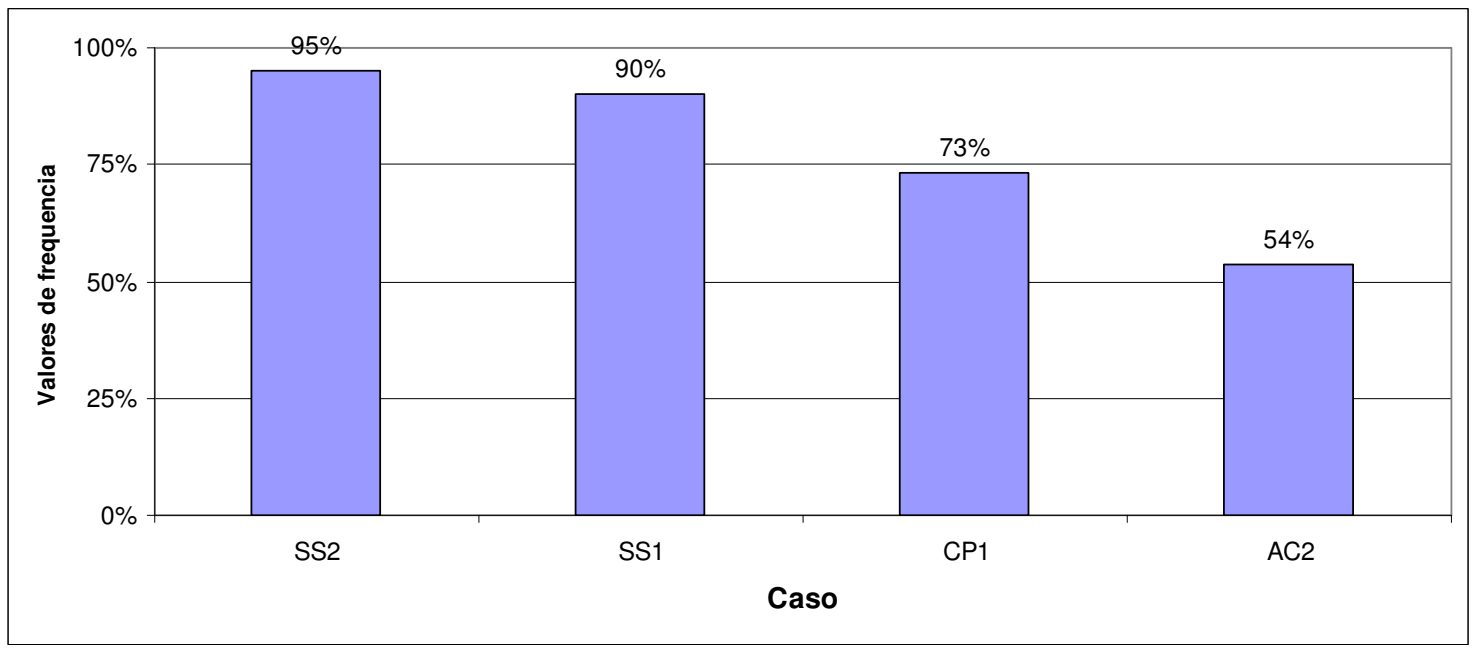

GRÁFICO 6.10 - Resultados para a freqüência nas diferentes empresas/entidades analisadas.

Fonte: Pesquisa do autor, 2007.

Pelo Gráfico 6.10 observa-se que nos casos SS1 e SS2 a freqüência foi relativamente alta ficando em torno de $90 \%$ e $95 \%$, respectivamente. Nessas duas empresas exige-se um determinado percentual de freqüência para a emissão de certificados e conclusão do curso. Essa regra, efetivamente, pressiona o cliente a ser mais freqüente. No caso CP1, muitos dos clientes são adolescentes cujos pais solicitam que a empresa acompanhe a freqüência dos mesmos. Já no caso AC2, não se exige um mínimo de freqüência por parte do cliente. Sua ida ao serviço é de caráter totalmente voluntário, e não está vinculada a objetivos como obtenção de certificado ou aprovação em exame. Vale ressaltar também que a freqüência relativamente menor observada ao longo do processo de SRUs como os oferecidos nos casos AC2 e CP1 deve ser considerada à luz dos padrões praticados no segmento de mercado analisado. 


\subsubsection{Considerações sobre os resultados encontrados}

Face aos resultados encontrados na avaliação do desempenho no processo de serviço dos casos SS1, SS2, CP1 e AC2 em termos de freqüência, taxa de retenção e eficácia, merecem destaque as seguintes observações:

- A freqüência medida pelas empresas/entidades situa-se no âmbito global. Os dados de freqüência coletados sobre a freqüência não diferenciam o percentual de freqüência dos clientes que obtiveram êxito nos resultados ulteriores daqueles que não obtiveram êxito. Em função dessa limitação, não foi possível obter evidências de que a freqüência mais elevada levaria a uma eficácia maior. Os dois casos reportados referentes às academias de ginástica podem ser ilustrativos sobre este aspecto. Apesar da baixa taxa de retenção e freqüência geral, os alunos que foram mais aderentes ao programa de atividades físicas são clientes que normalmente, freqüentam de modo regular a academia e acabam atingindo o resultado ulterior almejado;

- As diferentes taxas de retenção obtidas das empresas/entidades analisadas podem ser divididas em dois agrupamentos. No primeiro, estão as taxas obtidas no fim do período ao longo do qual um ciclo completo de um dado serviço é realizado. Enquadram-se nesse agrupamento as taxas de retenção nos cursos de formação profissional e cursos preparatórios. No segundo agrupamento, incluem-se as taxas obtidas, num intervalo de tempo qualquer. Estas taxas tendem a ser menores se o intervalo considerado for maior e vice-versa. Enquadramse neste agrupamento a taxa considerada nos casos de academia de ginástica;

- Todas as empresas/entidades analisadas estabeleceram, de modo claro, quais são os resultados ulteriores que buscam. Isso facilitou a identificação e coleta de indicadores referentes ao critério de desempenho eficácia do serviço oferecido. Mas tal situação de clareza nem sempre ocorre em SRUs. 
- Como qualidade é um critério de desempenho difuso no sistema organizacional, em função de sua importância em todos os estágios de gerenciamento do sistema (SINK e TUTTLE, 1993), o presente trabalho não contemplou sua análise total. Contudo, a utilização dos indicadores eficácia, freqüência e taxa de retenção estão indiretamente relacionadas a este critério. Os trabalhos de Vaughan e Shiu (2001) e Bennett e Barkensjo (2005) referentes à medição da qualidade em serviços do terceiro setor, e o de Chang e Chelladurai (2003) sobre a mensuração da qualidade em academias de ginástica, corroboram a idéia que o indicador eficácia seria uma das dimensões do critério de desempenho qualidade dos serviços estudados.

\subsubsection{A busca da eficiência}

Conforme analisado no referencial teórico deste trabalho, e apresentado nos casos relatados, os SRUs demandam a implementação de um sistema de monitoramento. Este, por sua vez, demanda recursos produtivos para ser aplicado sistematicamente. A adequada participação do cliente no processo é essencial para a obtenção dos efeitos pretendidos pelo serviço. Considerando os critérios de desempenho eficiência e eficácia, pode-se facilmente identificar a existência de um trade-off entre eficiência, que busca a minimização dos recursos a serem utilizados, e a eficácia, que depende destes recursos para se concretizar. Tal trade-off torna-se mais premente nos SRUs, na medida em que estes demandam recursos adicionais para o monitoramento dos efeitos pretendidos e das variáveis externas. Elementos como a participação dos clientes no processo, o modo como os recursos produtivos são utilizados e o comportamento da demanda afetam as dimensões de desempenho referentes à eficiência. Visando entender melhor como empresas/entidades que oferecem SRUs buscam maximizar a eficiência, algumas 
práticas que contribuem neste sentido foram identificadas nos casos estudados e são descritas nas seguintes seções.

\subsubsection{Participação do cliente como co-produtor}

Os estudos de caso possibilitaram identificar diferentes oportunidades de envolvimento do cliente no papel de co-produtor, ou seja, como funcionário parcial. Vários exemplos são citados a seguir:

- passagem do cartão na entrada ou saída da empresa (academia e cursos preparatórios), ajudando a registrar dados essenciais ao controle da sua freqüência;

- coleta da ficha de treinamento e preparação dos equipamentos de musculação nas academias;

- preenchimento de formulários para matrícula;

- realização de provas simuladas pela Internet, em que o cliente acaba assumindo a realização de várias atividades, antes relegadas aos funcionários da empresa.

\subsubsection{Racionalização do uso de recursos produtivos}

Nos cursos preparatórios verificou-se a utilização de mão-de-obra menos qualificada (estagiários) nas academias e nas monitorias.

Nas academias de ginástica, foi observado que a prescrição da atividade física pode ocorrer de maneira diferenciada conforme o horário de ginástica (manhã, tarde ou noite). Essa diferenciação por horário visa diminuir a procura por aparelhos mais escassos e reduzir também o tempo de espera. 
As academias e um curso preparatório adotam também regras relacionadas ao uso de aparelhos ou instalações, estipulando um tempo máximo de ocupação e definindo regras de agendamento.

\subsubsection{Estratégias para influenciar a demanda}

Foram identificadas três estratégias que as empresas pesquisadas têm utilizado para influenciar a demanda. A primeira refere-se à oferta de pacotes promocionais para o período de baixa demanda (constatada nos cursos preparatórios e academias de ginástica). A segunda refere-se ao uso de sistemas de reservas, por meio de matrículas. Finalmente, a terceira refere-se à elaboração de contratos que penalizam o cancelamento, inibindo a captura de clientes "oportunistas" que tendem a não compensar financeiramente a empresa bem como a desistência do cliente. 


\section{CONCLUSÕES}

Este capítulo apresenta as conclusões gerais do trabalho frente ao objetivo proposto pela tese, com base na pesquisa de campo realizada e em sua análise. Em seguida, as contribuições secundárias do trabalho são apresentadas. Finalmente, são expostas algumas sugestões para futuras pesquisas.

\subsection{VERIFICAÇÃO DAS PROPOSIÇÕES DE PESQUISA}

\subsubsection{A primeira proposição e os resultados encontrados}

Retomando a proposição de pesquisa $\mathrm{P}_{1}$, este trabalho procura verificar se a obtenção de níveis satisfatórios de eficácia em empresas de SRU que processam pessoas é suportada pela implementação de um sistema de monitoramento e controle voltado para o relacionamento da organização com o seu público.

Conforme já ressaltado no capítulo de metodologia de pesquisa, a $\mathrm{P}_{1}$ deve ser analisada nos casos investigados comparando-se os valores de eficácia obtidos com o grau de aplicação das características e práticas do sistema de monitoramento e controle considerados no framework teórico. Os Gráficos 7.1 e 7.2 mostram os valores destas variáveis em cada caso analisado. 


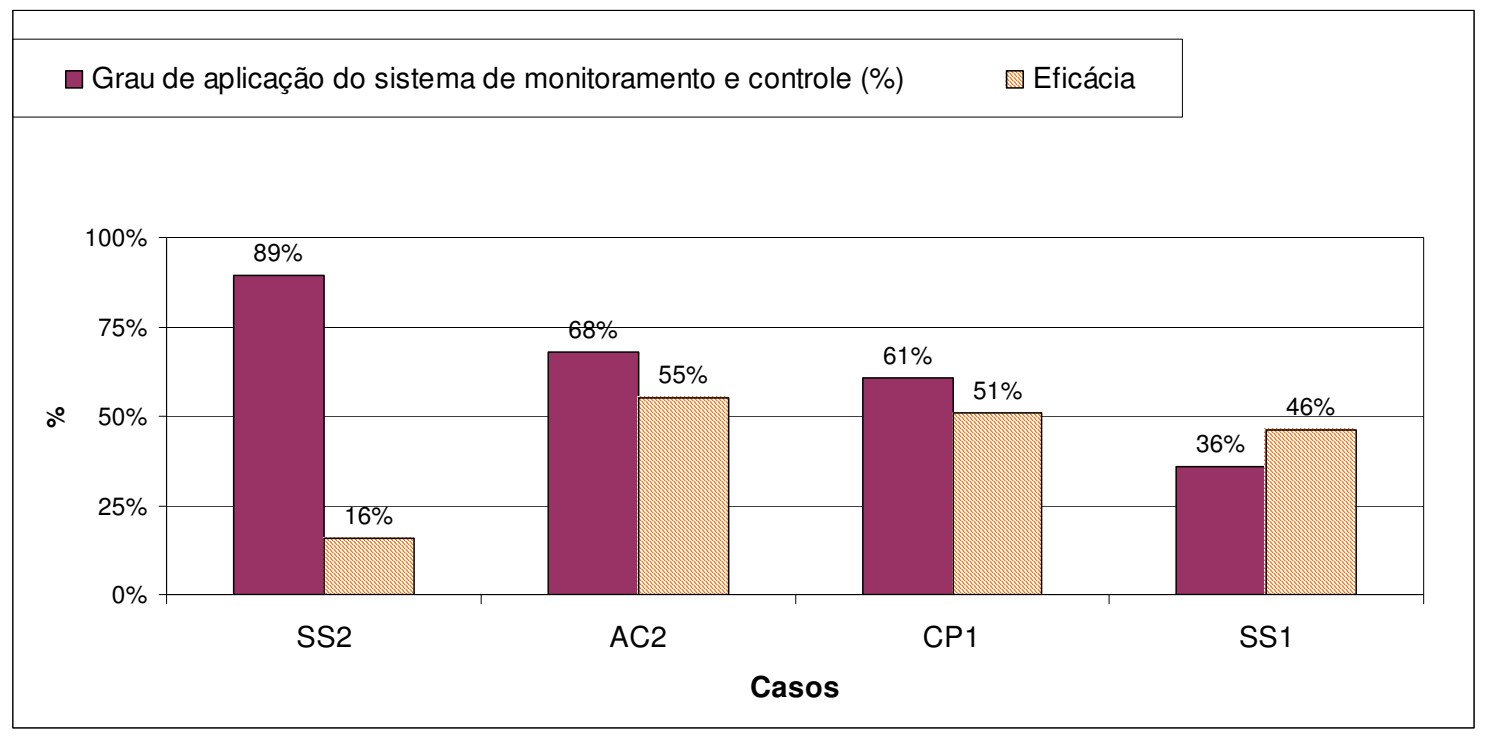

GRÁFICO 7.1 - Valores de eficácia e grau de aplicação do sistema de monitoramento e controle.

Fonte: Pesquisa do autor, 2007.

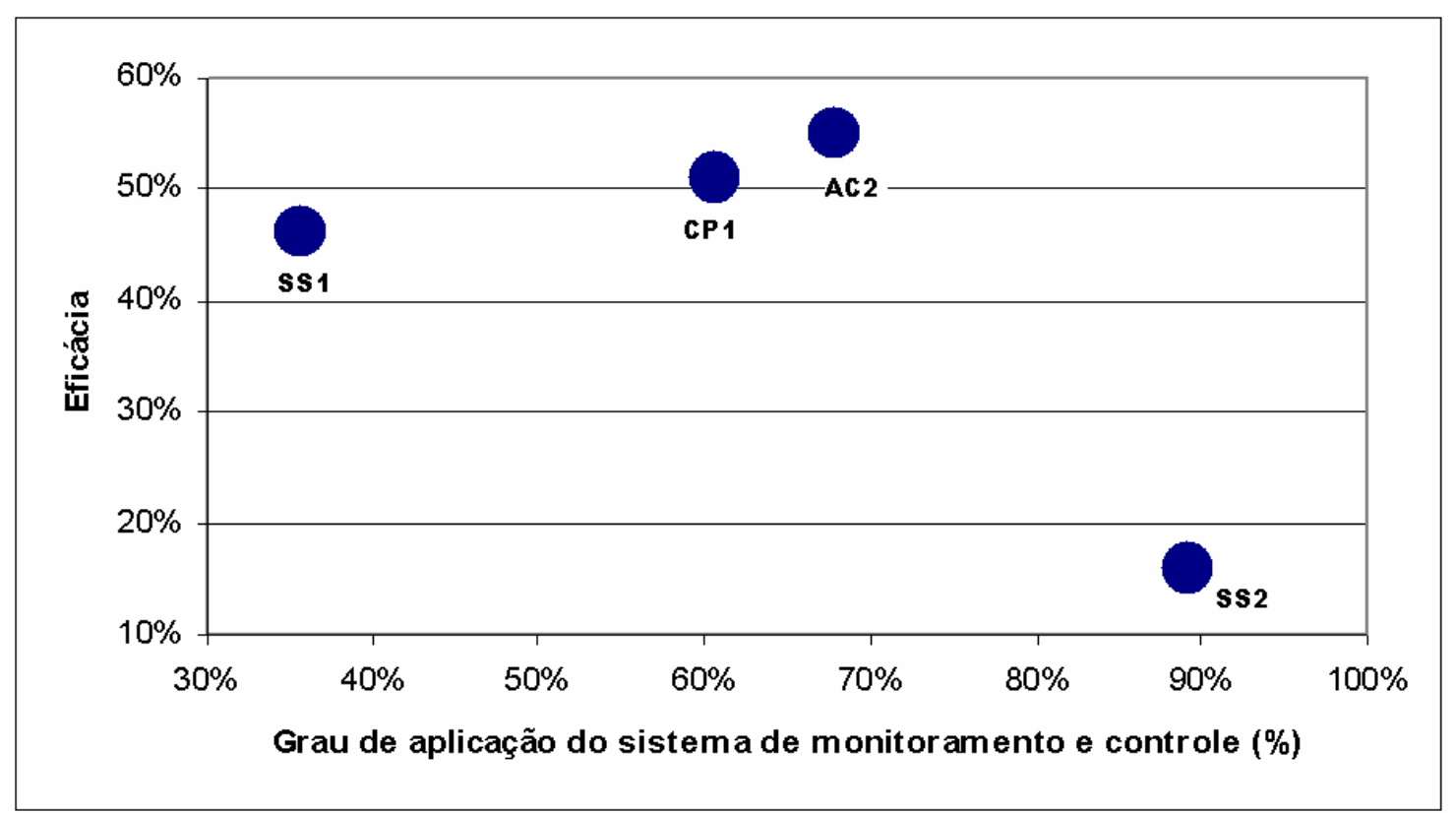

GRÁFICO 7.2 - Resultados de eficácia e o grau de aplicação das características e práticas referentes ao sistema de monitoramento e controle.

Fonte: Pesquisa do autor, 2007. 
Pelo Gráfico 7.1 observa-se que o caso SS2 apresenta um valor de eficácia significativamente menor apesar do grau de aplicação das características e práticas referentes ao sistema de monitoramento. O que explicaria este resultado? Uma possível resposta a essa pergunta seria a forte influência de variáveis externas, que fogem ao controle da empresa, sobre os efeitos ulteriores buscados nesse tipo de SRU.

Como já ressaltado na seção 6.1.2, é preciso procurar entender os resultados obtidos no caso SS2 levando em conta também as características intrínsecas do serviço prestado que denotam uma complexidade operacional muito maior.

Se, por um lado, o caso SS2 apresenta uma baixa eficácia apesar do alto grau de aplicação do sistema de monitoramento e controle, por entre os três demais casos parecem corroborar a $\mathrm{P}_{1}$, conforme se vê no Gráfico 7.2.

A $\mathrm{P}_{1}$ levantada no trabalho foi analisada tomando-se como referência 0 resultado conjunto de quatro das empresas pesquisadas, não considerando as especificidades de cada setor. Contudo tal ponderação torna-se particularmente relevante quando houver evidências qualitativas que justifiquem considerações complementares. Neste sentido, vale salientar que o caso SS2, apesar de apresentar a menor eficácia dentre as empresas/entidades comparadas, é tido como referência nacional no atendimento educacional de jovens com necessidades especiais (deficiência mental), tendo suas práticas educacionais reconhecidas e divulgadas pela Secretaria de Educação Especial do Ministério da Educação por meio de um documento sobre educação inclusiva (BRASIL, 2005). Assim sendo, não obstante o valor de eficácia encontrado para o caso SS2 ser relativamente inferior, o mesmo pode ser admitido como expressivo e exemplar para o tipo de SRU que oferece, no contexto brasileiro.

Concluindo, sob a perspectiva de uma análise conjunta, verificou-se que a eficácia de um SRU depende do sistema de monitoramento, mas pode ser prejudicada pela influência de fatores externos, tal como ocorre no caso SS2. Levando-se em conta a maior complexidade operacional e a maior influência de variáveis externas sobre o SRU do caso SS2, pode-se concluir que a proposição $P_{1}$ não pode ser refutada. 


\subsubsection{A segunda proposição e os resultados encontrados}

Resgatando a definição da proposição de pesquisa $\mathrm{P}_{2}$, este trabalho procurou verificar se a obtenção de níveis satisfatórios de eficácia em empresas de SRU que processam pessoas é suportada pela adoção de táticas que favoreçam maior participação e envolvimento dos clientes nas atividades.

Conforme já ressaltado no capítulo de metodologia de pesquisa, a $\mathrm{P}_{2}$ deve ser analisada nos casos considerados comparando-se os valores de eficácia obtidos com o grau de adoção de táticas que favoreçam maior participação e envolvimento dos clientes nas atividades. Os Gráficos 7.3 e 7.4 mostram os valores destas variáveis em cada caso analisado.

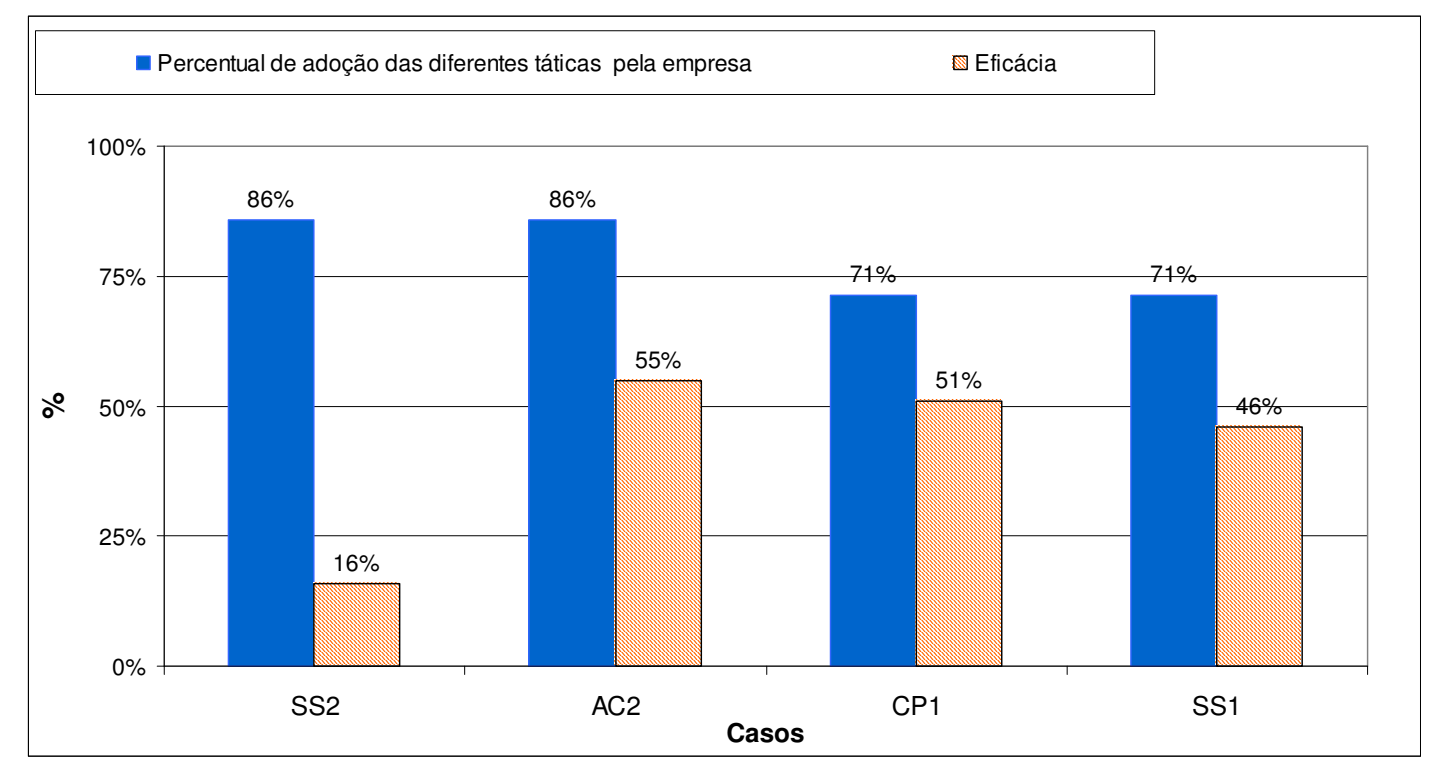

GRÁFICO 7.3 - Valores de eficácia e grau de adoção de táticas que possam favorecer maior participação e envolvimento dos clientes nas atividades.

Fonte: Pesquisa do autor, 2007. 


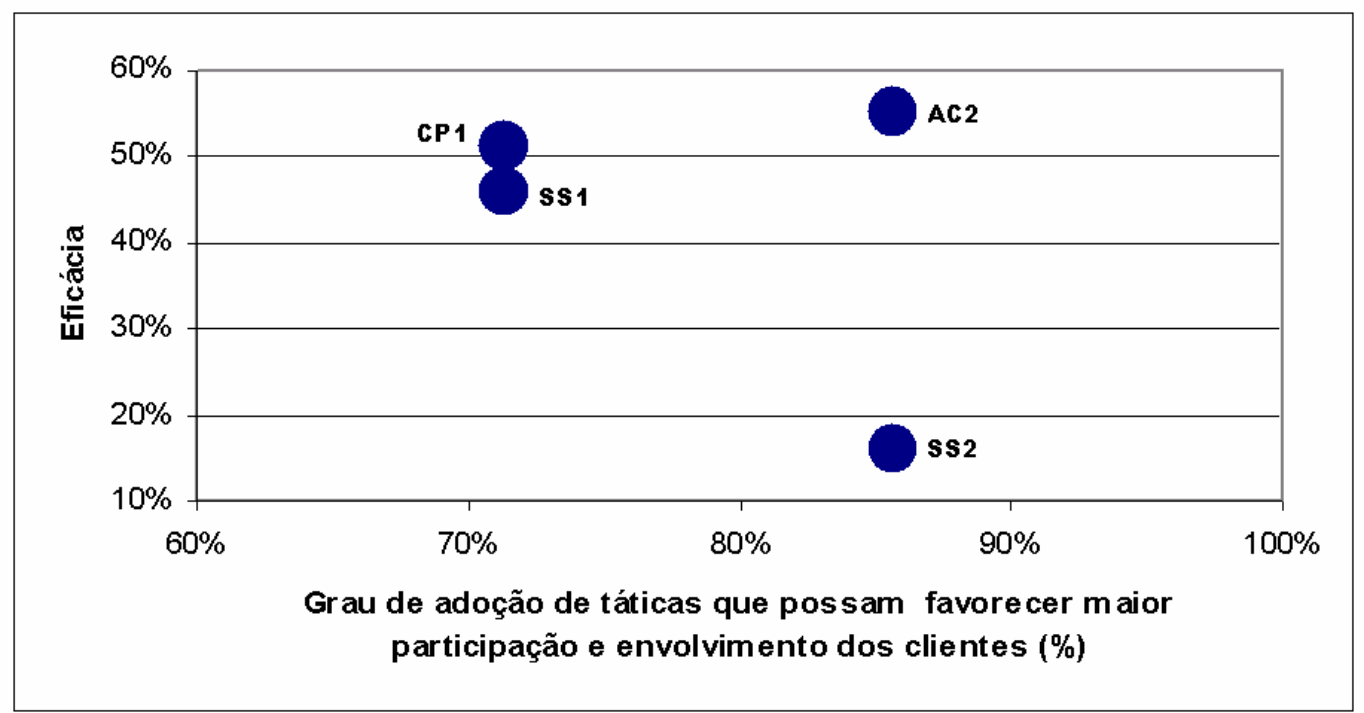

GRÁFICO 7.4 - Resultados de eficácia e grau de adoção de táticas que possam favorecer maior participação e envolvimento dos clientes nas atividades.

Fonte: Pesquisa do autor, 2007.

Pelo posicionamento dos casos considerados no Gráfico 7.4 observa-se a inexistência de uma relação entre os valores de eficácia e grau de adoção de táticas que favoreçam maior participação e envolvimento dos clientes nas atividades e, portanto, $\mathrm{P}_{2}$ não pode ser aceita.

\subsubsection{A terceira proposição e os resultados encontrados}

Retomando a proposição de pesquisa $\mathrm{P}_{3}$, este trabalho procurou verificar se a retenção de clientes em empresas de SRU que processam pessoas é influenciada pela capacidade do sistema de monitoramento e controle existente em realizar ajustes e correções em seu processo de entrega do serviço. 


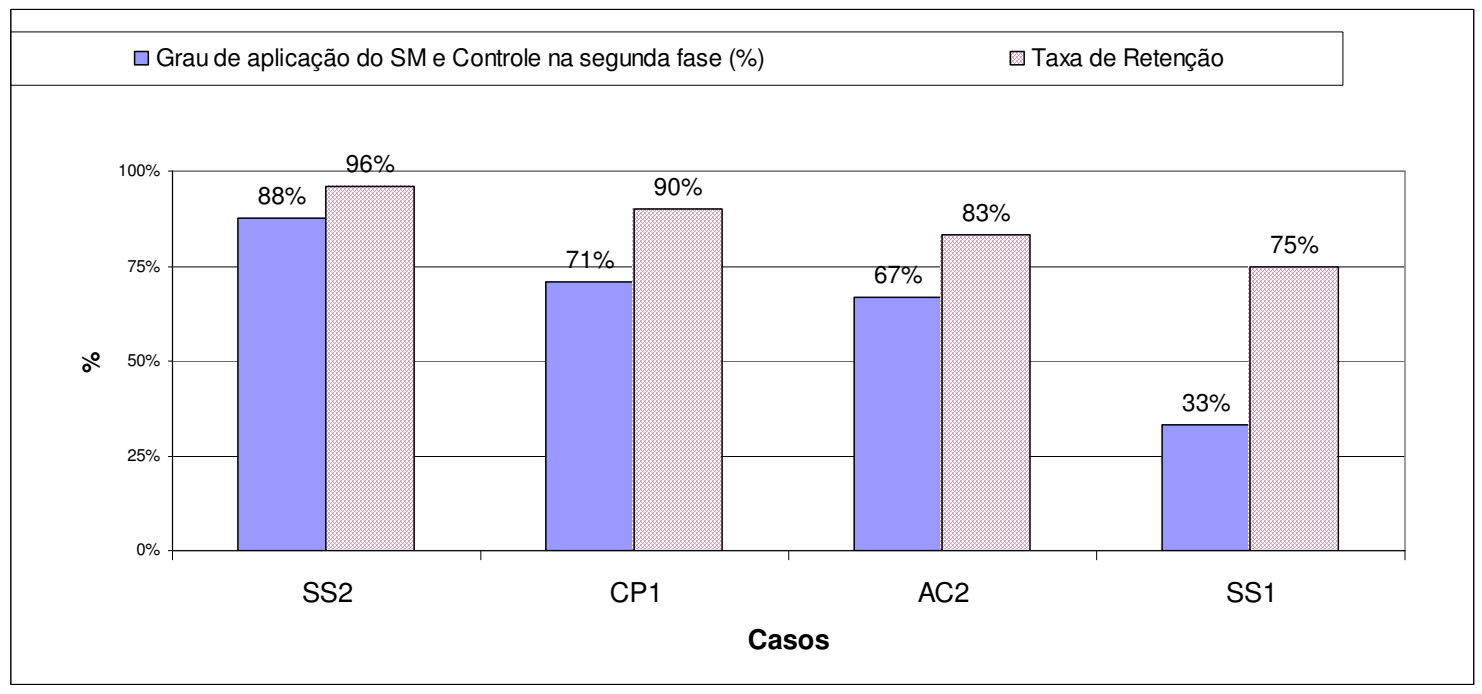

GRÁFICO 7.5 - Valores de retenção e grau de aplicação das características e práticas referentes à segunda fase do sistema de monitoramento e controle. Fonte: Pesquisa do autor, 2007.

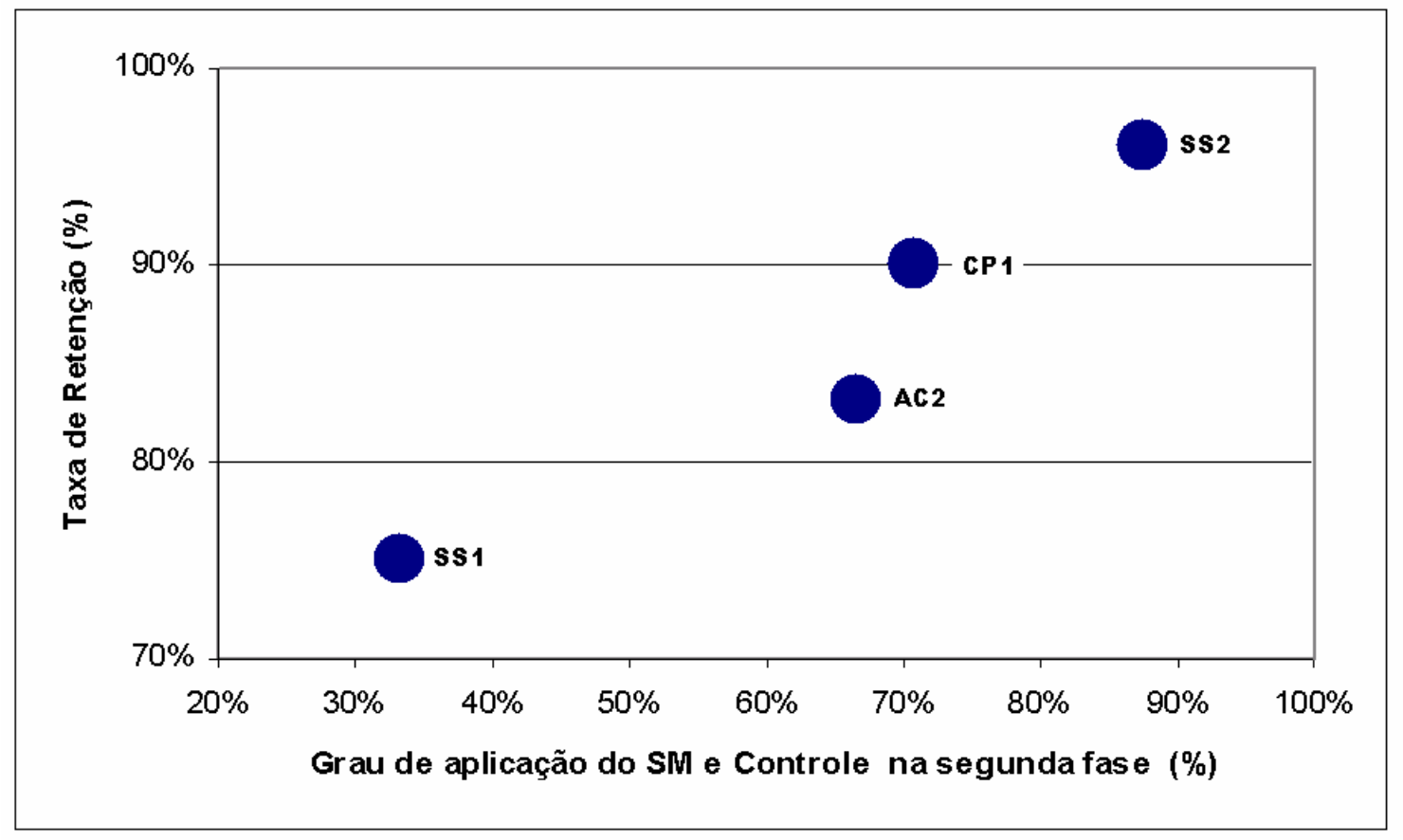

GRÁFICO 7.6 - Resultados de retenção e grau de aplicação das características e práticas referentes à segunda fase do sistema de monitoramento e controle. Fonte: Pesquisa do autor, 2007. 
Conforme já ressaltado no capítulo de metodologia de pesquisa, a $\mathrm{P}_{3}$ deve ser analisada nos casos investigados comparando-se os valores de retenção obtidos com o grau de aplicação das características e práticas referentes à segunda fase do sistema de monitoramento e controle considerados no framework teórico. Os Gráficos 7.5 e 7.6 mostram os valores destas variáveis em cada caso analisado.

Esta proposição $P_{3}$ é embasada pela argumentação de que um sistema de monitoramento e controle capaz de realizar ajustes e correções em seu processo de entrega do serviço fortalece os benefícios para os clientes pelo estabelecimento de um relacionamento mais efetivo entre o mesmo e a empresa. Como já mencionado na seção 3.3.3, estes benefícios possibilitam maior conveniência e customização dos serviços para os clientes. Na medida em que o suporte de um sistema de monitoramento possibilita o conhecimento do histórico dos clientes e o ajuste do serviço às suas necessidades, portanto a sua efetiva aplicação habilitaria o provedor a oferecer essas duas vantagens.

Pelo posicionamento dos casos considerados no Gráfico 7.6, observa-se a existência de uma relação entre os valores de retenção e o grau de aplicação das características e práticas referentes à segunda fase do sistema de monitoramento e controle destinado a suportar o processo de um SRU, indicando que quanto maior a primeira variável, maior tende a ser a segunda. Pode-se concluir portanto que a proposição $P_{3}$ não pode ser refutada.

\subsection{CONTRIBUIÇÕES SECUNDÁRIAS DO TRABALHO}

\subsubsection{Trade-off entre eficiência e eficácia}

O presente estudo considerou a existência de um trade-off entre eficiência e eficácia. Várias táticas são sugeridas neste trabalho para melhorar esses dois critérios de desempenho. A consideração de uma relação de trade-off, pode ser 
fundamentada no modelo da gangorra proposto por Silveira e Slack (2001). Neste modelo, o pivô e a base, conforme ilustra a Figura 7.1, são formados por elementos internos do sistema produtivo:

- Recursos: Estoques de fatores disponíveis, pertencentes ou controlados pela empresa. São constituídos pela tecnologia, métodos e competências da empresa;

- Capacidades: são constituídas dos processos, atividades ou funções realizadas dentro do sistema produtivo;

- Atributos: Refletem a efetividade da base formada pelos recursos e capacidades existentes na empresa para o atendimento dos diferentes objetivos de desempenho. Os atributos tornam o sistema (base) capaz de fornecer os níveis desejados de desempenho de modo confiável. Por exemplo: atributos como produtividade e flexibilidade interna afetam o trade-off entre custos e qualidade.

Sob a perspectiva dos conceitos propostos por Silveira e Slack (2001), podese vislumbrar uma relação entre as táticas sugeridas e o efeito de cada uma delas nos dois critérios de desempenho. Isto é possível na medida em que as táticas sugeridas podem ser entendidas como componentes da base no modelo de tradeoff. Portanto, as táticas podem levar à ocorrência de três modos, já retratados na Figura 3.19 da seção 3.4 .

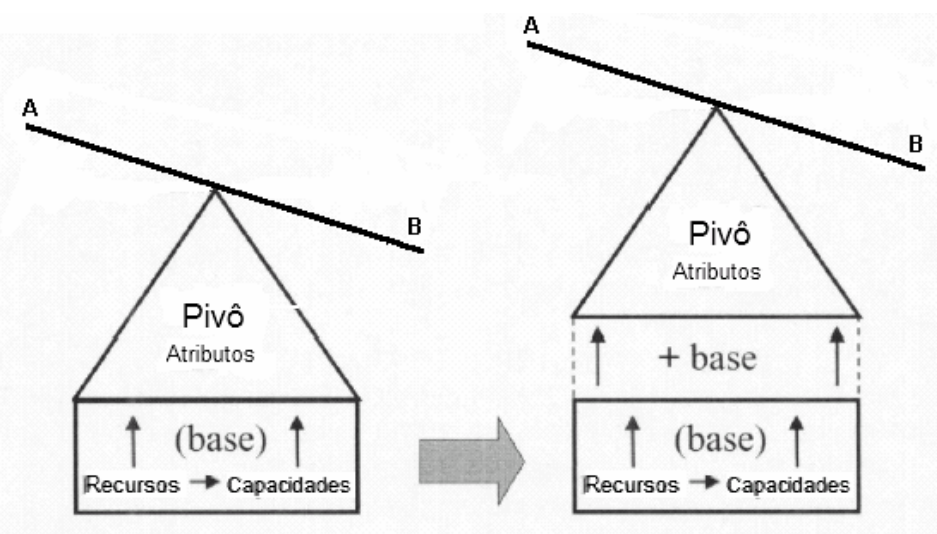

FIGURA 7.1 - Papéis dos recursos, capacidades e atributos no modelo de trade-off Fonte: Adaptada da Figura 4 de Silveira e Slack (2001). 
- i) o desempenho pelo critério competitivo A melhora, mas isso afeta negativamente o desempenho pelo critério $\mathrm{B}$;

- ii) o desempenho de um critério competitivo A melhora, sem prejudicar o desempenho pelo critério $B$;

- iii) mudança nos atributos do sistema pode melhorar o desempenho tanto pelo critério $A$ como pelo critério $B$, sem uma mudança relativa entre os mesmos.

Como contribuição secundária deste trabalho, as táticas/rotinas empregadas pelas empresas estudadas e as sugestões contidas na bibliografia referentes ao sistema de monitoramento e controle e à utilização dos recursos produtivos internos foram compiladas e chegou-se a uma relação de 20 alternativas de táticas/rotinas que podem ser utilizadas para a melhoria da eficiência e/ou eficácia. A cada tática/rotina identificada, de um modo exploratório, analisou-se o seu potencial efeito nos dois critérios de desempenho - eficiência e eficácia - e classificou-se o tipo de trade-off que ocorreria segundo a tipologia proposta por Silveira e Slack (2001). Todas estas táticas/rotinas sugeridas estão enumeradas no Apêndice A. Por exemplo, a tática 1 sugerida no Apêndice $A$ refere-se ao treinamento dos funcionários em múltiplas tarefas. Esta tática leva a uma melhor utilização dos recursos disponíveis podendo melhorar a eficiência da operação, sem entretanto afetar a eficácia dos serviços. Na medida em que melhora o desempenho pelo critério eficiência sem afetar o desempenho pelo critério eficácia, a tática 1 afeta 0 trade-off eficiência versus eficácia no modo ii, segundo a tipologia de Silveira e Slack (2001). Já a tática 17 de fornecer suporte ao cliente durante a realização das atividades afeta negativamente a eficiência da operação, devido à utilização de recursos como funcionários para este fim. Entretanto, tal prática contribuíra para a eficácia do serviço na medida em que permitirá que o cliente realize suas atividades de modo mais adequado. Nesta situação o desempenho pelo critério eficiência é afetado negativamente, mas o desempenho pelo critério eficácia é melhorado, portanto a tática 17 afeta o trade-off eficiência versus eficácia no modo i, segundo a tipologia de Silveira e Slack (2001). Já a tática 7 sugere a seleção dos clientes pela empresa. Uma boa seleção possibilita um menor esforço de preparação e 
treinamento dos clientes, afetando positivamente a eficiência da operação. Esta mesma tática poderá contribuir para uma maior eficácia, na medida que a mesma possibilita a escolha de perfis de clientes mais adequados ao cumprimento dos objetivos propostos pelo serviço. Nesta situação, tanto o desempenho pelo critério eficiência como pelo critério eficácia são melhorados, portanto a tática 7 afeta o trade-off eficiência versus eficácia no modo iii, segundo a tipologia de Silveira e Slack (2001). Além destes 3 exemplos, o Apêndice A enumera várias outras táticas/rotinas, esclarecendo se afetam o trade-off eficiência versus eficácia no modo i, ii ou iii.

\subsubsection{Mapa de Relacionamento}

Para descrever melhor não apenas como o relacionamento entre a empresa/entidade e os clientes está estruturado no processo de um SRU mas também como ocorre o registro de dados pelo sistema de monitoramento implementado foi proposto à aplicação do Mapa de Relacionamento. Esta ferramenta foi desenvolvida com base nos trabalhos de Holmlund (1997 e 2004). Originalmente, esta autora montou um diagrama para descrever apenas a hierarquia das interações que ocorrem no relacionamento entre as empresas e seus clientes. $O$ Mapa de Relacionamento aproveita esta estrutura hierárquica para descrever as principais seqüências, episódios e atos que constituem 0 processo de relacionamento da empresa com seus clientes. Além disso, ele descreve quais atos são registrados pelo sistema e como estes são registrados (preenchidos em formulários, digitados num sistema informatizado ou registrados automaticamente por um sistema informatizado). É interessante notar que o nível de detalhamento do Mapa de Relacionamento depende do grau de repetibilidade do processo de serviço. Processos em que os atos se repetem com grande freqüência podem ser melhor descritos por esta ferramenta. Portanto, entende-se que o Mapa de Relacionamento 
é uma ferramenta particularmente poderosa para descrever o relacionamento em SRUs que apresentam uma maior repetibilidade.

Pode-se facilmente derivar novas aplicações para esta ferramenta. Ela também pode ser utilizada como um complemento ao blueprinting (técnica para descrição e planejamento do processo de serviço), na definição ou melhoria do sistema de informação existente e/ou scripts utilizados nos serviços.

Embora a concepção e aplicação do Mapa de Relacionamento tenha sido um meio, e não um fim, no contexto da pesquisa desenvolvida pode ser entendido como uma contribuição secundária que o presente trabalho gerou para suportar a formalização e aprimoramento dos processos de planejamento e gerenciamento de sistemas de operação em serviços.

\subsubsection{Meio para avaliação do sistema de monitoramento em SRUs}

Como mencionado na seção 2.3, para o atendimento do objetivo proposto no trabalho foi necessário desenvolver métodos para avaliar o grau de aplicação do sistema de monitoramento e controle (ver seção 3.5.1) e o grau de adoção de táticas que possam estimular o envolvimento e a participação dos clientes (ver seção 3.5.2). Os dois métodos aplicados neste trabalho podem contribuir para uma melhor avaliação de SRUs, indicando necessidades de melhoria na gestão de processos de serviços não apenas deste tipo, mas também suportar o desenvolvimento de processos de serviço mais consistentes, fornecendo diretrizes para sua implementação. 


\subsubsection{Maior compreensão da operação de SRUs}

O presente trabalho se propôs a distinguir os serviços pela predominância de produtos diretos ou de seus resultados ulteriores. Como já ressaltado no trabalho, esta forma de classificação não foi ainda contemplada pela literatura estudada, o que indica ser uma perspectiva original para o tratamento de processos de serviços. Isso significa que a compreensão de alguns serviços sob esta nova ótica representa uma desafio relevante para acadêmicos e profissionais que atuam no setor de serviços. Assim sendo, a descrição e discussão de seis casos de processos de serviços que puderam ser enquadrados como SRUs elucidando vários aspectos fundamentais para a gestão de suas operações, em si, constituem uma primeira iniciativa neste sentido.

\subsection{OBJETIVOS ESPECÍFICOS NA TESE}

Uma vez que a partir objetivo geral da tese, foram estabelecidos quatro objetivos específicos, esta seção tece algumas considerações sobre 0 atendimento a estes no trabalho.

Em relação ao primeiro objetivo, a descrição dos casos exposta nos Capítulos 5 e 6 desta tese possibilitou a identificação dos meios que foram adotados pelas organizações de SRUs analisadas para o monitoramento e controle dos seus serviços, permitindo portanto o seu atendimento.

Como já ressaltado nas seções 7.2.2 e 7.2.3, o presente trabalho desenvolveu dois métodos que podem contribuir para uma melhor avaliação de SRUs, indicando necessidades de melhoria na gestão de processos de serviços. Soma-se a isto, o desenvolvimento da ferramenta do Mapa de Relacionamento que permite descrever o relacionamento da organização com os clientes em SRUs e sua forma de monitoramento. Estes métodos e esta ferramenta ajudam na avaliação e 
controle do processo de serviços, e permitem desdobrar ações gerenciais que visem ao melhoramento dos mesmos. Entende-se assim que o trabalho atende ao segundo objetivo específico.

Como já exposto na seção 7.2.1, o trabalho apresenta uma relação de 20 alternativas de táticas/rotinas que podem ser utilizadas para a melhoria da eficiência e/ou eficácia levando-se em consideração os três modos de trade-off. O trabalho contribui assim para um melhor entendimento de como objetivos operacionais conflitantes como eficiência e eficácia podem ser administrados em SRUs atendendo ao terceiro objetivo específico.

O quarto objetivo específico se refere ao desenvolvimento de métodos para avaliar o grau de aplicação de um sistema de monitoramento e controle e o grau de adoção de táticas que estimulam o envolvimento e a participação dos clientes. Como já exposto nesta seção, dois métodos foram desenvolvidos no trabalho para tais fins contribuindo, portanto, para uma melhor análise e avaliação de SRUs.

\subsection{LIMITAÇÕES DO TRABALHO}

Nesta seção, são delineadas algumas limitações deste trabalho e da pesquisa realizada.

A primeira delas se refere ao tipo de dado coletado na pesquisa, ou seja, os dados coletados nas organizações estudadas retratam o ponto de vista dos gestores destes serviços. A percepção dos serviços sob o ponto de vista dos clientes não foi contemplada neste trabalho, na medida em que apenas os responsáveis pela supervisão do processo de entrega destes serviços foram entrevistados e estes, certamente, têm um viés próprio que influencia suas decisões em termos de desenho, operação e controle do processo de entrega do serviço.

Por razões descritas no capítulo 4, o desenvolvimento da pesquisa apoiou-se no método do estudo de múltiplos casos. Se considerarmos o estágio de desenvolvimento do tema abordado, outros métodos de pesquisa tais como estudo 
de caso aprofundado e pesquisa-ação poderiam ser também utilizados para analisar os SRUs. Nesta direção, entende-se que a utilização de outros métodos de pesquisa em SRUs pode elucidar vários aspectos que não foram explorados ou não puderam ser aprofundados neste trabalho.

Vale lembrar que o trabalho analisou apenas organizações de SRU que estabeleceram, de modo claro, quais seriam os resultados ulteriores almejados. Assim, a pesquisa não contemplou as especificidades de SRUs cujos resultados ulteriores não podem ser claramente caracterizados, medidos e avaliados.

Para a avaliação do desempenho dos SRU analisados na tese, três indicadores foram utilizados: freqüência, taxa de retenção e eficácia. Apesar do estabelecimento de critérios comuns para o cálculo destes indicadores, algumas diferenças para o cálculo destes foram constatadas e apontadas na seção 6.4.3.4. Estas diferenças podem ser atribuídas às características intrínsecas dos três tipos de serviços analisados.

Finalmente, no que tange às proposições de pesquisa, o trabalho investigou mecanismos que possam favorecer a retenção de clientes e a eficácia do serviço, contudo não foi viável explorar ações gerenciais que pudessem influenciar a freqüência do cliente, enquanto usuário do SRU.

\subsection{RECOMENDAÇÕES PARA FUTURAS PESQUISAS}

Algumas sugestões para futuras pesquisas são delineadas nesta seção. Elas são oriundas de insights obtidos com a realização da pesquisa de campo e a revisão da literatura consultada.

O presente trabalho tratou apenas de SRUs já existentes e em operação. Sugere-se, desse modo, estudos sobre o processo de desenvolvimento de novos SRUs. Nesta direção, sugere-se a adoção da estrutura conceitual proposta para descrever o processo de desenvolvimento de serviços definida no trabalho de Torres Júnior; Miyake e Pereira (2006) e Torres Júnior e Miyake (2005). 
No presente trabalho, um dos estudos de caso revelou o uso de uma equipe multidisciplinar para a condução do serviço de formação profissional de jovens portadores de deficiência. O exemplo dessa entidade põe em evidência o uso de equipes multifuncionais nos SRUs. Várias questões podem ser levantadas sobre este tema. Por exemplo: Quais são as dificuldades e os desafios para a condução do gerenciamento das operações, ao se utilizarem equipes multidisciplinares?

O trabalho não se aprofundou na discussão dos métodos de medição de desempenho, restringindo-se a analisar três indicadores específicos. Contudo, é evidente a necessidade de um entendimento mais profundo sobre este tema nos SRUs.

Todas as empresas/entidades analisadas estabeleceram, de modo claro, quais seriam os resultados ulteriores almejados. Mas nem sempre isso pode estar bem definido num SRU. É importante compreender quais seriam as implicações para as empresas que oferecem tal tipo de serviço, da falta de definição ou da definição imprecisa dos resultados ulteriores almejados no gerenciamento de suas operações.

Finalmente, o presente trabalho introduz a discussão do gerenciamento de uma nova categoria de serviços que foi definida como SRU. Acredita-se que vários outros temas, não mencionados aqui, poderão vir a serem explorados com foco nesta categoria de serviços, visando ao desenvolvimento de seu planejamento e gerenciamento. 


\section{REFERÊNCIAS BIBLIOGRÁFICAS}

ARAUJO, G. Malhação com prazer. Jornal Estado de Minas, Belo Horizonte, 04 Jun. 2006. Caderno Bem Viver, 2006, p. 7

ARMISTEAD, C.; JOHNSTON, R.; SLACK, N. The Strategic determinants of Service Productivity. International Journal of Operations \& Production Management, v. 8, n. 5, p. 95-108, 1988.

BATISTA, C. A. M. Inclusão no Trabalho. In. Batista, C. A. M. (Org.) Inclusão dá trabalho. Belo Horizonte: Armazém de Idéias, 2000, p. 11- 45

BENNETT, R.; BARKENSJO, A. Relationship quality, relationship marketing, and client perceptions of the levels of service quality of charitable organisations. International Journal of Service Industry Management, v. 16, n. 1, p. 81-106, 2005

BERRY, L. L.; PARASURAMAN, A. Serviços de marketing: competindo através da qualidade. São Paulo: Maltese, 1995, 238 p.

BITNER, M. J. et al. Customer contributions and roles in service delivery. International Journal of Service Industry Management, v. 8, n. 3, p.193- 205, 1997.

BOWEN, D. E. Managing Customers as Human Resources in Service Organizations. Human Resource Management, v. 25, n. 3, p. 371-383, 1986.

BRASIL, Secretaria de Educação Especial. Educação Inclusiva: Atendimento Educacional Especializado para a Deficiência Mental. Brasília: MEC/SEESP, 2005.

CHANG, K.; CHELLADURAI, P. System-Based Quality Dimensions in Fitness Services: Development of the Scale of Quality. The Service Industries Journal, v. 23, n. 5, p. 65-83, 2003.

CHASE, R. B. Where does the customer fit in a service operation? Harvard Business Review, Nov./Dec., p. 137-42, 1978.

COOK, D. P; GOH, C.; CHUNG, C. H. Service typologies: A state of the art survey. Production and Operations Management, v. 8, n. 3, p. 318-338, 1999.

CORRÊA; H. L.; GIANESI, I. G. N. Administração estratégica de serviços: Operações para a Satisfação do Cliente. São Paulo: Editora Atlas, 1994. 
CAON, M. Gestão de serviços: lucratividade por meio de operações e de satisfação dos clientes. São Paulo: Atlas, 2002, 480 p.

CORRÊA, C. A.; Administração de produção e operações: Manufatura e Serviços - Uma Abordagem Estratégica. São Paulo: Editora Atlas, 2004, 694 p.

DEMING, W. E. Qualidade: a revolução da administração. Rio de Janeiro: Marques-

Saraiva, 1990, $367 \mathrm{p}$.

EDGETT, S.; PARKINSON, S. Marketing for Service Industries - A Review. The Service Industries Journal, v. 13, n 3, p. 19-39, 1993.

EDVARDSSON, B. et al. New service development and innovation in the new economy. Lund: Studentlitteratur, 2000, 227 p.

GUSTAFSSON, A.; ROOS, I. Service portraits in service research: a critical review. International Journal of Service Industry Management, v. 16, n. 1, p. 107121, 2005.

FITZSIMMONS, J. A.; FITZSIMMONS, M. J. Administração de serviços: operações, estratégia e tecnologia de informação. Porto Alegre: Bookman Companhia Editora, 2000, $3^{\circ}$ edição.

Administração de serviços: operações,

estratégia e tecnologia de informação. Porto Alegre: Bookman Companhia Editora, 2005, $4^{\circ}$ edição.

GADREY, J. Emprego, produtividade e avaliação do desempenho dos serviços. In:

SALERMO, M. S. (org.) Relação de serviço: produção e avaliação. São Paulo: Editora SENAC São Paulo, 2001, p. 24-65.

The characterization of goods and services: an alternative approach. Review of Income and Wealth, v. 46, n. 3, p. 369-387, 2000.

GIL, A. C. Métodos e técnicas de pesquisa social. São Paulo: Editora Atlas, 1999, 206p.

GRÖNROOS, C. Marketing: gerenciamento e serviços. Rio de Janeiro: Elsevier, 2003, $481 \mathrm{p}$.

OJASALO, K. Service productivity Towards a conceptualization of the transformation of inputs into economic results in services. Journal of Business Research, v. 57, p. 414-423, 2004. 
GROVE, S. J.; FISK, R. P. The Impact of Others Customers on Service Experiences: A Critical Incident Examination of "Getting Along". Journal of Retailing, v. 73, n. 1, p. 63-85, 1997.

GUMMESSON, E. Marketing de relacionamento total: gerenciamento de marketing, estratégia de relacionamento e abordagens de CRM para a economia de rede. Porto Alegre: Bookman, 2005, 323 p.

GUSTAFSSON, A.; JOHNSON, M. D. Competing in a service economy: how to create a competitive advantage through service development and innovation. John Wiley \& Sons, 2003, 190 p.

GWINNER, K. P; GREMLER, D. D; BITNER, M. J. Relational benefits in services industries: The customer's perspective. Academy of Marketing Science Journal, v. 26, n. 2, p. 101114, 1998.

HAKSEVER, C. et al. Service management and operations. New Jersey: Prentice Hall, 2000, $584 \mathrm{p}$.

HANDFIELD, R. B.; MELNYK, S. A. The scientific theory-building process: a primer using the case of TQM. Journal of Operations Management, v. 16, p. 321-339, 1998.

HESKETT, J. L.; SASSER JR., W. E.; SCHLESINGER, L. A. Lucro na prestação de serviços: como crescer com a lealdade e a satisfação dos clientes. Rio de Janeiro: Editora Campus Ltda, 2002, 332 p.

HOFFMAN, K. D.; BATESON, J. E. G. Princípios de marketing de serviços: conceitos, estratégias e casos. São Paulo: Pioneira Thomson Learning, 2003.

HOLMLUND, M. Perceived. Quality in business relationships. Helsinki: Swedish School of Economics and Business Administration, 1997, 336 p.

Analyzing business relationships and distinguishing different interaction levels. Industrial Marketing Management, v. 33, p. 279-287, 2004.

STRANDVIK, T. Perception configurations in business relationships. Management Decision, v. 37, n. 9, p. 687-696, 1999.

HRONEC, S. Sinais vitais: usando medidas do desempenho da qualidade, tempo e custo para traçar a rota para o futuro de sua empresa. São Paulo: Makron Books, 1994, 240 p.

JOHNE, A.; STOREY, C. New service development: a review of the literature and annotated bibliography. European Journal of Marketing, v. 32, n. 3/4, p. 184-251, 1998. 
JOHNSTON, R.; CLARK, G. Administração de operações de serviço. São Paulo: Editora Atlas, 2002, $562 \mathrm{p}$.

UPDATE Service operations management: from the roots up. International Journal of Operations \& Production Management, v. 25, n. 12, p. 1298-308, 2005.

JONES, P. Service productivity: Towards understanding the relationship between operational and customer productivity. International Journal of Productivity and Performance Management, v. 53, n. 3, p. 201-213, 2004.

JONG, J. P. J.; VERMEULEN, P. A M. Organizing successful new service development: a literature review. Management Decision, v. 41, n. 9, p. 844-858, 2003.

JURAN, J. M. Na Liderança pela qualidade: um guia para executivos. São Paulo: Livraria Pioneira Editora, 1990, 386 p.

KAPLAN, R.; NORTON, D. A estratégia em ação: balanced scorecard - como as empresas que adotam o balanced scorecard prosperam no novo ambiente de negócios. Rio de Janeiro: Campus, 1997.

KEATING, E. K. et al. Overcoming the Improvement Paradox. European Management Journal, v. 17, n. 2, p. 120-134, 1999.

KELLOGG, D. L.; NIE, W. A framework for strategic service management. Journal of Operations Management, v. 13, p. 323-337, 1995.

KON, A. Economia de serviços: teoria e evolução no Brasil. Rio de Janeiro: Elsevier, 2004, 269 p.

KOTLER, P. Administração de marketing. São Paulo: Prentice Hall , 2000, 764 p.

LARSSON, R.; BOWEN, David E. Organization and Customer: Managing Design and Coordination of Services. The Academy of Management Review, v. 14, n. 2, p. 213-33, 1989.

LAS CASAS, A. L. Marketing de serviços. São Paulo: Editora Atlas, 1991, 163 p.

LENGNICK-HALL, C. A. Customer contributions to quality: a different view of the customeroriented firm. Academy of Management Review, v. 21, n. 3, p. 791-824, 1996.

LEVITT, T. Production-Line Approach to Service. Harvard Business Review, Set.-Out., p. 41-52, 1972. 
LOVELOCK, C. H. Classifying Services to Gain Strategic Marketing Insights. Journal of Marketing, v. 47, p. 9-20, 1983.

Competing on service: technology and teamwork in supplementary services. Planning Review, July./Aug., 10 p., 1995.

GUMMESSON, E. Whither Services Marketing? In Search of a New

Paradigm and Fresh Perspectives. Journal of Service Research, v. 7, n. 1, p.20-41, 2004.

WRIGHT, L. Serviços: marketing e gestão. São Paulo: Saraiva, 2002,

$416 \mathrm{p}$.

YIP, G. S. Developing Global Strategies for Service Businesses.

California Management Review, v. 38, n. 2, p. 64-86, 1996.

WIRTZ, J. Marketing de Serviços: pessoas, tecnologia e resultados.

São Paulo: Pearson Prentice Hall, 2006, 412 p.

YOUNG, R. F. Look to consumers to increase productivity. Harvard

Business Review, May/June, p. 168-178, 1979.

MAPES, J.; NEW, C.; SZWEJCZEWSKI, M. Performance trade-offs in manufacturing plants. International Journal of Operations \& Production Management, v. 17, n. 10, p. 1020-33, 1997.

MELLO, C. H. P. Modelo para projeto e desenvolvimento de serviços. 2005. 315 p. Tese (Doutorado). Departamento de Engenharia de Produção, Escola Politécnica, Universidade de São de Paulo. São Paulo, 2005.

NEELY, A.; et al. Designing performance measures: a structured approach. International Journal of Operations \& Production Management, v. 17 n. 11, p. 1131-52, 1997.

MENOR, L. J.; TATIKONDA, Mohan V.; SAMPSON, Scott E. New service development: areas for exploitation and exploration. Journal of Operations Management, v. 20, p. 135157, 2002.

MEREDITH, J. Building operations management theory through case and field research. Journal of Operations Management, v. 16, p. 441-454, 1998.

MILLS, P. K.; MORRIS, J. H. Clients as Partial Employees of Service Organizations: Role Development in Client Participation. Academy of Management Review, v. 11, n. 4, p. 726735, 1986. 
NOBRE, L. (Re) Projetando a academia de ginástica. São Paulo: Phorte Editora Ltda, 2000, $165 \mathrm{p}$.

NÓBREGA, K. C. Gestão da qualidade em serviços. 1997. 328 p. Tese (Doutorado). Departamento de Engenharia de Produção, Escola Politécnica, Universidade de São de Paulo. São Paulo, 1997.

NORMANN, R. Administração de serviços: estratégia e liderança na empresa de serviços. São Paulo: Editora Atlas, 1993.

OJASALO, K. Customer Influence on Service Productivity. SAM Advanced Management Journal, p. 14-19, 2003.

OLIVA, R.; KALLENBERG, Robert Managing the transition from products to services. International Journal of Service Industry Management, v. 14, n. 2, p. 160-172, 2003.

PFEIFFER, P. O Quadro Lógico: um método para planejar e gerenciar mudanças. Revista do Serviço Público, v. 51, n. 1, Jan. - Mar., p. 81-120, 2000.

Gerenciamento de projetos de desenvolvimento: conceitos, instrumentos e aplicações. Rio de Janeiro: Brasport, 2005, 182 p.

ROCHE, C. Avaliação de impacto dos trabalhos de ONGs: aprendendo a valorizar as mudanças. São Paulo: Cortez: ABONG, 2002, 348 p.

ROSEN, A. Systematic Planned Practice. Social Service Review, Mar., p. 84-100, 1993.

SASSAKI, R. Implicações do Paradigma da Inclusão para o Emprego de Pessoas com Deficiência In. Batista, C. A. M. (Org.) Inclusão dá trabalho. Belo Horizonte: Armazém de Idéias, 2000, p. 83-110

SCHMENNER, R. W. How Can Service Business Survice and Prosper? Sloan Management Review, Spring, p. 21-32, 1986.

Futura, 1999, $422 \mathrm{p}$.

Administração de operações em serviços. São Paulo: Editora

SCHNEIDERMAN, A. M. Setting Quality Goals. Quality Progress, Apr., p. 51-57, 1988.

SHOSTACK, G. L. Planning the Service Encounter. In: CZEPIEL, John A.; SOLOMON, Michael R.; SURPRENANT, Carol F. (Eds.), The service encounter: managing 
employee/customer interaction in service business. New York: Lexington Books, 1985, p. 243-253.

Service positioning throught structural change. Journal of Marketing, v.

51, p. 34-43, Janeiro, 1987.

SILVEIRA, G. da; SLACK, N. Exploring the trade-off concept. International Journal of Operations \& Production Management, v. 21, n. 7, p. 949-964, 2001.

SILVESTRO, R.; FITZGERALD, L.; JOHNSTON, R. Towards a Classification of Service Process. International Journal of Service Industry Management, v. 3, n. 3, p. 62-75, 1992.

SINK, D. S.; TUTTLE, T. C. Planejamento e medição para a performance. Rio de Janeiro: Qualitymark Editora, 1993.

SKINNER, W. Manufacturing - missing link in the corporate strategy. Harvard Business Review, May-June, p. 136-145, 1969.

SLACK, N. et al. Administração da produção. São Paulo: Editora Atlas S.A., 2001.

LEWIS, M.; BATES, $\mathrm{H}$. The two worlds of operations management research and practice: Can they meet, should they meet?. International Journal of Operations \& Production Management, v. 24, n. 4, p.372-87, 2004.

Operations strategy: will it ever realize its potential? Gestão \& Produção, v. 12, n. 3, p. 323-332, 2005.

SOUZA, V. L. de et al. Gestão de desempenho. Rio de Janeiro: Editora FGV, 2005, 151 p.

STUART, I. et al. Effective case research in operations management: a process perspective. Journal of Operations Management, v. 20, p.419-433, 2002.

SURPRENANT, C. F.; SOLOMON, M. R. Predictability and Personalization in the Service Encounter. Journal of Marketing, v. 51, p. 86-96, 1987.

TÉBOUL, J. A era dos serviços: uma nova abordagem de gerenciamento. Rio de Janeiro: Qualitymark, 1999, 295 p.

TORRES JÚNIOR, N.; MIYAKE, D. I.; Towards the systematization of the service development process: guidelines for the development of the control plan. XXVI Annual Conference of POMS, Chicago, IL, April 29 - May 2, 2005. 
PEREIRA, C. C. de P. Proposta de um modelo de referência para descrever o Processo de Desenvolvimento de Serviços. VIII Simpósio de Engenharia de Produção, UNESP, Bauru, Novembro de 2006.

VAUGHAN, L.; SHIU, E. ARCHSECRET: A multi-item scale to measure service quality within the voluntary sector. International Journal of Nonprofit and Voluntary Sector Marketing, v. 6, n. 2, p. 131-144, 2001.

VIEIRA, S. Como escrever uma tese. São Paulo: Pioneira Thomson Learning, 2002, 102 p.

VOSS, C.; TSIKRIKTSIS, N.; FROHLICH, M. Case research in operations management. International Journal of Operations \& Production Management, v. 22, n. 2, p. 195-219, 2002.

WEMMERLOV, U. A taxonomy for Service Process and its Implications for System Design. International Journal of Service Industry Management, n. 1\&3, p. 20-40, 1990.

WIKSTRÖM, S. The customer as co-producer. European Journal of Marketing, v. 30, n. 4, p. 6-19, 1996.

WINER, R. S. A Framework for Customer Relationship Management. California Management Review, v. 43, n. 4, p. 89-105, 2001.

YIN, R. K. Estudo de Caso: Planejamento e métodos. Porto Alegre: Bookman, 2002, 199 p.

ZANETTE, E. T. Análise do perfil dos clientes de academias de ginástica: o primeiro passo para o planejamento estratégico. 2003. 154p. Dissertação (Mestrado) - Escola de Engenharia, Universidade Federal do Rio Grande do Sul. Porto Alegre, 2003.

ZEITHAML, V. A; BITNER, M. J. Marketing de serviços: a empresa com foco no cliente. Porto Alegre: Bookman, 2003, 536 p. 


\section{APÊNDICE}




\section{APÊNDICE A - Táticas/rotinas sugeridas para a melhoria da eficiência e/ou}

\section{eficácia}

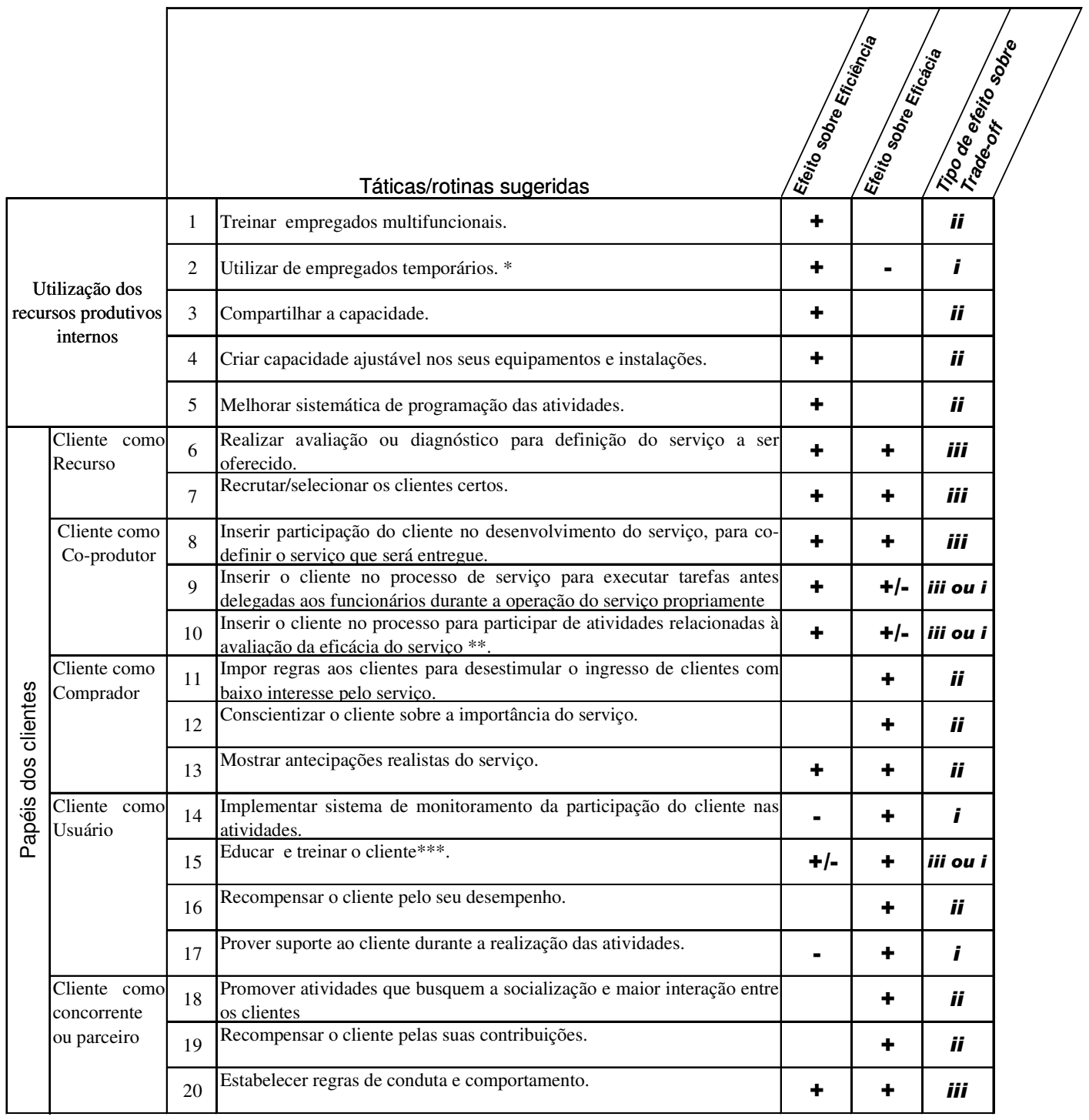

* Existe o risco dos funcionários temporários não terem a experiência e o conhecimentos dos outros colegas.

** A eficácia poderá ser comprometida se o cliente não estiver devidamente preparado/capaz.

*** Demanda recursos inicialmente, mas pode ser compensatória, principalmente se houver uma grande retenção de clientes. 
ANEXOS 


\section{ANEXO A - Roteiro da entrevista}

\section{A) Dados gerais da empresa:}

1) Nome

2) Número de funcionários:

3) Principais recursos existentes:

4) Tempo de existência:

5) Público alvo:

6) Principais stakeholders:

7) Serviços oferecidos:

8) Capacidade de atendimento:

9) Prêmios ou certificações obtidos:

B) Sistema de registro das atividades realizadas pelo cliente no serviço e seus resultados

1) Descreva as principais seqüências existentes para a entrega do serviço.

2) Quais seqüências de atividades são registradas (monitoradas)?

3) Para cada seqüência registrada, responda:

3.1) Qual é menor nível de detalhamento existente em cada uma destas seqüências?

Descreva:

3.2) Quem realiza as atividades de registro ?

3.3) Qual é o grau de informatização e automação do sistema?

3.4) O que é registrado :

3.4.1) Informações referentes às atividades realizadas/ produtos imediatos.

Exemplos: tempo de permanência no local, atividades realizadas no dia, frequiência, etc.;

3.4.2) Informações sobre os resultados ulteriores. Exemplos: nota final obtida, taxa de emagrecimento; resultado final do exame, quantidade de pessoas inseridas no mercado de trabalho, etc.

3.4.3) Informações sobre algumas variáveis externas que estão sob o controle do cliente e que podem influenciar os resultados ulteriores do serviço. Exemplos: realização de dieta, etc.

\section{C) Sistema de análise dos registros das atividades realizadas pelo cliente no serviço} e seus resultados:

1) Das seqüências e/ou episódios que são registrados, quais são analisados ?

2) Para cada um deles responda:

2.1) Com qual periodicidade?

2.2) Quem realiza a análise?

2.3) O que é analisado?

2.4) Qual(is) o(s) tipo(s) de ação(ões) que é(são) tomada(s)? Descreva a(s) mesma(s). 
D) Atividades de avaliação realizadas nos episódios não registradas pelo sistema

1) Existem episódios que não são registrados, mas que são analisados de modo informal? Caso afirmativo, quais?

2) Para cada um deles responda:

2.1) Quando isto ocorre?

2.2) Quem realiza a análise?

2.3) O que é analisado?

2.4) Qual(is) o(s) tipo(s) de ação(ões) que é(são) tomada(s)? Descreva a(s) mesma(s).

\section{E) Rotina de diagnóstico do cliente}

Existe uma rotina de diagnóstico do cliente para definir as atividades que serão realizadas, quando o mesmo ingressa no serviço?

Caso afirmativo, como a mesma é realizada?

\section{F) Rotina de seleção dos clientes}

Existe uma rotina de seleção dos clientes para ingressar no serviço?

Caso afirmativo, como a mesma é realizada?

\section{G) Táticas que favorecem maior participação e envolvimento dos clientes}

1) A empresa educa e treina o cliente para a realização das atividades? Caso afirmativo, como isto é feito?

2) A empresa adota atividades que promovam a socialização dos clientes ? Caso afirmativo, como isto é feito?

3) A empresa procura recompensar o cliente pelo seu maior envolvimento e participação nas atividades? Caso afirmativo, como isto é feito?

4) A empresa estabelece regras e condutas de comportamento para seus clientes? Caso afirmativo, como isto é feito?

5) A empresa fornece algum tipo de suporte e apoio durante a realização das atividades (orientando, esclarecendo dúvidas e estimulando sua participação)? Caso afirmativo, como isto é feito?

6) A empresa envolve o cliente no planejamento/definição das atividades que serão realizadas por ele? Caso afirmativo, como isto é feito?

7) A empresa realiza atividades que visem à conscientização da importância do serviço? Caso afirmativo, como isto é feito?

\section{H) Busca de eficiência na operação}

1) Como é conciliada a necessidade de monitorar o cliente com o custo de realizar esta atividade?

2) Quais ações são tomadas no sentido de reduzir o custo de monitoramento?

3) Quais são os indicadores existentes para monitorar a eficiência da operação? Como eles são utilizados? 


\section{ANEXO B - Normas de conduta estabelecidas conjuntamente aos alunos}

\section{- NORMAS -}

1. Todos devem respeitar e todos devem ser respeitados.

2. Não vale mexer nos objetos dos outros sem a autorização do próprio dono. Quem fizer isto deverá receber uma ocorrência e quem se apropriar de objetos do outros, deverá ser SUSPENSO. Cabe a cada cuidar do que é seu;

3. Não vale provocar o colega, falar mentira e palavrões;

4. Devemos assumir a responsabilidade com relação aquilo que fazemos e falamos;

5. Nos casos de agressão verbal, o aprendiz deverá receber uma OCORRÊECIA. Nos casos de agressão fisica ele deverá ser SUSPENSO.

5. Três (3) OCORRÊNCIAS equivalem à um (1) dia de SUSPENSÃO;ou dependendo da gravidade até três dias consecutivos.

6. O horário de trabalho dever ser respeitado. Nos casos de falta, serão abonadas aquelas que forem justificadas por um atestado médico, por motivo de falecimento de um familiar ou por requisição de trabalho de outra atividade profissional, comprovada por uma declaração. $O$ aprendiz que assinar ao ponto e não trabalhar terá seu ponto cortado. As faltas sem justificativas custarão R\$2,00 por dia para cada aprendiz.

7. O BASE é o nosso espaço de trabalho. Ele deve ser sempre organizado e limpo. Cabe a cada um de nós zelar por isto. Por exemplo: usar adequadamente o banheiro, manter organizado seu espaço de trabalho, guardar seus objetos pessoais, ter postura adequada ao ambiente de trabalho.

8. Para o bom desempenho e cuidados com a saúde são preciso que se use os equipamentos de segurança:

- óCULOS DE PROTECÃO;

- AVENTAL LIMPO;

- LUVAS

- CREME PARA AS MÃOS.

9. Não podemos esquecer também dos exercícios de alongamento que previnem lesões.

O APRFNDIZ que não realizar estes procedimentos terá seu dia descontado.

10. A equipe de profissionais e aprendizes do BASE poderá alterar estas normas quando for necessário.

Revisão em:Maio de 2006

OBS: Os alunos são chamados de aprendizes. 
ANEXO C - Normas de conduta para o curso preparatório para o vestibular

$$
\text { Pedinos si z compreansa }
$$

e colaturaczo vara o que sa segue

- É proibido o uso de telefone celular durante as aulas, mantenha-o desligado;

- O acesso às aulas só será permitido mediante registro eletrônico através da tarja magnética de sua carteirinha;

- A permanência no pátio e corredores deve ser evitada em horário de aula;

- A entrada em sala de aula deve ser imediatamente após o sinal;

- Haverá uma tolerância de 15 minutos de atraso no primeiro horário. Chegando após esse periodo, favor aguardar o horário seguinte e a saída do professor (caso sua saída seja prevista no horário de aulas);

- Em caso de atraso nos demais horários, aguarde o horário seguinte;

- Salvo em caso de urgência, ao aluno que se retirar da sala, pede-se que aguarde o horário seguinte para retornar, evite o entra e sai da sala pois prejudica a atenção dos colegas e professores.

- O aluno só poderá ser chamado na sala por solicitação relevante feita à secretaria do curso, que se encarregará de chamar o aluno;

- Não marque carteiras para outras pessoas, os lugares nas carteiras são por ordem da chegada;

- Caso você tenha combinado encontrar-se com alguém aqui no curso, procure sair da sala antes do horário marcado;

- Durante as aulas, o aluno deve concentrar-se no conteúdo que estiver sendo exposto, evitando conversa com o (s) colega (s);

- O estacionamento de veículos só é permitido dentro da faixa amarela, o que viabiliza a utilização organizada da área por um número razoável de carros e evita multas.

Todas as medidas acima visam, apenas, ao melhor aproveitamento das aulas, ao conforto e a tranqüilidade de todos. Qualquer dúvida ou sugestão, favor dirigir-se a nossos funcionário ou a diretoria, sempre que necessário.

Atenciosamente,

A DIREÇÃO 